


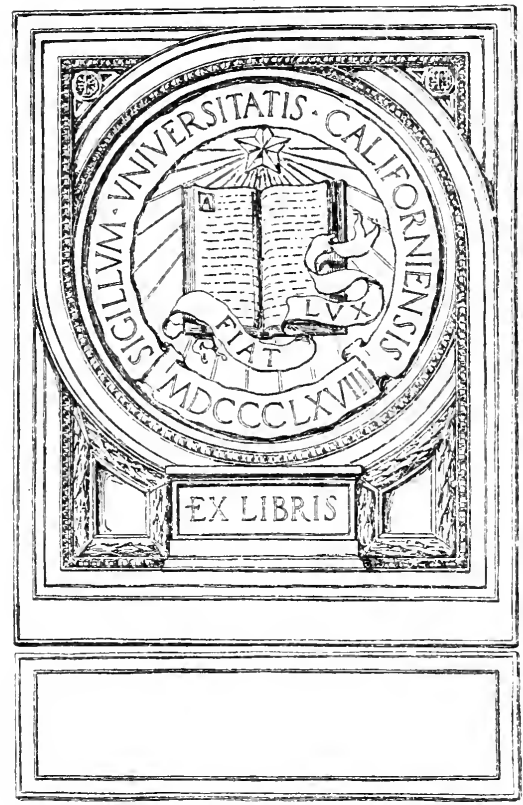




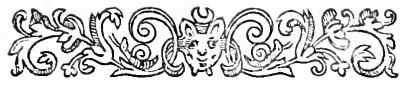

\section{项ibrary of Dld Zutbors.}

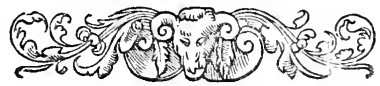






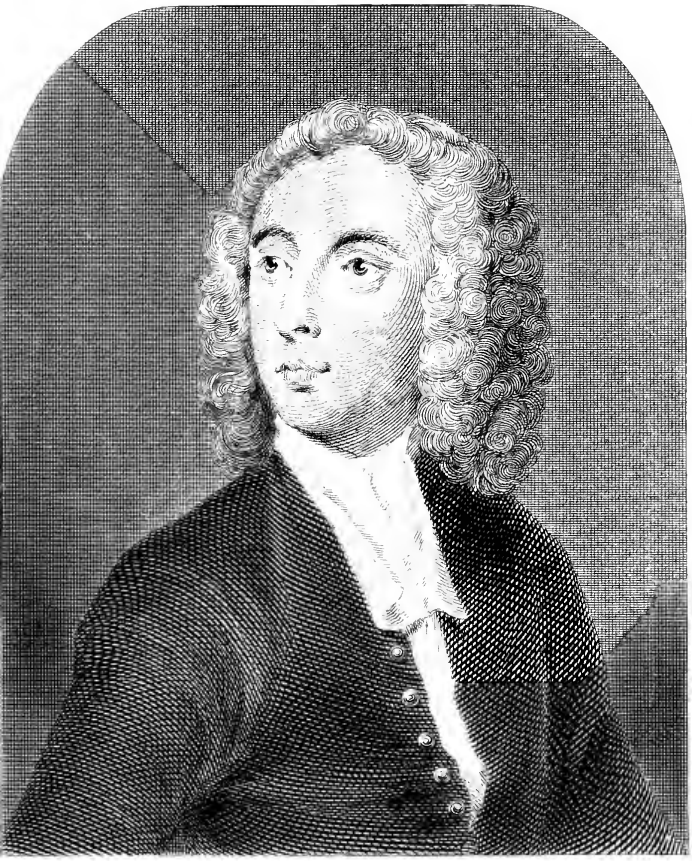

$$
\text { Joseph Ppence. }
$$




\section{ANECDOTES, OBSERVATIONS, ANI)}

\section{CHARACTERS, OF BOOKS}

\section{AND MEN.}

COLLECTED FROM THE CONVERSATION OF MR. POPE, AND OTHER EMINENT PERSONS OF HIS TIME.

BY THE REV. JOSEPH SPENCE. WITH NOTES, AND A LIFE OF THE AUTHOR. BY SAMUEL WELLER SINGER, F.S.A.

Sccond EDition.

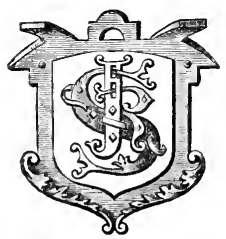

LONDON:

JOHN RUSSELL SMITH, SOHO SQUARE.

1858. 


$$
{ }^{3} x^{5} 1^{01}
$$

49623 


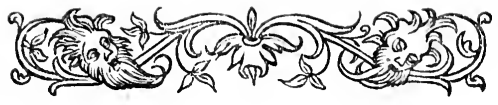

\section{PRELIMINARY NOTICE.}

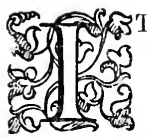

T may be proper to state that this re-impression of Spence's Aneedotes has been printed verbatim from my former elition, withont the slightest alteration.

I embrace this opportunity of supplying a deficiency in the preface, which ought to have mentioned the source from which these Anecdotes were derived.

On the decease of Spence the whole of his papers passed into the hands of Dr. Lowth (afterwards Bishop of London), one of his exceutors, by whom, at a period long subsequent, they were given to a gentleman of the name of Forster, who held some confidential post under the Bishop. At Mr. Forster's death they became the property of his nephew, from whom Mr. William Carpenter obtained them, and placed them in my hands with a view to this publieation.

\section{S. W. SINGER.}

May 29, 1858. 
Apis matina

More modoque

Grata carpentis thyma. 


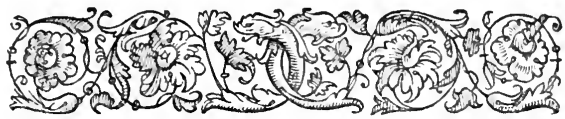

\section{THE EDITOR'S PREFACE.}

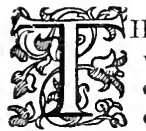

IIE French abound in collections of this nature. which they have distinguished with the title of Ana. England has produced few examples: of the kind, but they are eminently excellent. It may be sufficient to name Selden's Table Talk, Boswell': Life of Johnson, and the Walpoliana.

Mr. Spence seems to have been doubtful what title he should give to this collection: and those of Popiana. Spenceana, Symposia, and Table Talk, appear to have been successively adopted and rejected.

Whaterer may have been the motive with which this compilation was begun, it was evidently continued, completed, and transcribed, with a view to the public; Mr. Spence had conditionally sold it to Dodsley, meditating its posthumous publication, but his executors were armed with a discretionary power, and prevailed upon the Bookseller to forgo his claim, probably deeming many of the Anecdotes of too recent date for publication, or possibly thinking them of too trifling a nature to add anything to the reputation of their friend; or it may have been in compliance with the wish of Lord Lineoln, (afterwards Duke of Neweastle, ) who was averse to their being made public. One of the manuseript copies was, therefore, presented to his Lordship, and the other consigned to a chest with all $\mathrm{Mr}_{1}$. Spence's manuscript remains. It is thus that these Ancedotes have 
hitherto remained a Sealed Book, exeept to a privileged few. Some of them, indeed, found their way to the public through the medium of Warburton, Warton, Johnson, and Malone. To the two first of these writers they were communicated by Mr. Spence himself. Among his papers, I find this memorandum, dated April 7 th, $1744 .-" \mathrm{Mr}$. Warburton thinks of writing Mr. Pope's Life, whenerer the world may have so great a loss, and I offered to give him any lights I could toward it."

He afterwards gare Dr. Warton the following more cireumstantial account :

"As they returned in the same earriage together from Twickenham, soon after the death of Mr. Pope, and joined in lamenting his death, and celebrating his praises, Dr. Warburton said he intended to write his life; on which Mr. Spence, with his usual modesty and condescension, said that he also had the same intention; and had from time to time collected from Mr. Pope's own mouth, rarious particulars of his life, pursuits, and studies; but would readily give up to Dr. Warburton all his eollections on this subject, and aceordingly eommunieated them to him immediately."

" Warburton (says Mr. Tyers) was entangled by late friendships et recentibus odiis. Ilis prospects of elevation in the ehwrch, made him too great for his subject. He did nothing on this oceasion; but thirty years afterwards he assisted Ruffhead, and revised the life, as written by his locm teners, sheet by sheet." This is no doubt a true aeeount of the transaetion, for in 1761 , Warburton says to his friend Hurd, "I have sometimes thought of eolleeting my seattered anecdotes, and critieal observations together, for a foundation of a Life of Pope, which the booksellers teaze me for, you could help me nobly to fill up the canvas." This hint does not appear to have been seized by Hurd with the avidity that was perhaps expeeted, and the Iife of Pope did not make its appearance until the 
year 1769. Owen Ruffhead seems to have been a dull plodding lawyer, and all that is of value in this ponderous performanee, must be attributed to Wirburton, whose hand may be traced upon every important topie in the book. Almost every aneelote of interest in that Life of Pope is derived from this collection, and always without acknowledgment. It is remarkable that it should not be published until the year after Spence's death, as if there was some eonseiousness of this appropriation.-Warburton affected to speak eontemptuously of Spence; had he any intimation that Spence had ever spoken, as he has written, that - Warburton was, thirty years since, an attorney at Newark, and got into orders by spitting into a nobleman's fiee at an election!"”

Dr. Warton lived in habits of friendship with Spenee, and has enlivened his delightful Essay on the Genius and Writings of Pope, with many particulars derived from these aneedotes; and makes the following grateful acknowledgment, which is of the greater value, as it eame too late to flatter the living ear of his friend. After mentioning Spence's Essay on the Odyssey as a work of the truest taste, he says: "I am indebted to this learned and amiable man, on whose friendship I set the greatest value, for most of the aneedotes relating to Pope, mentioned in this work, which he gave me when I was making him a visit at Byfleet, in 175t."

When Dr. Johnson was engaged to write the Lives of the Poets, applieation was made to the Duke of Neweastie, by Sir Lueas Pepys, for the loan of his manuseript, and it was eoneded to his use in the most liberal manner. $\mathrm{He}$ acknowledges the "great assistance" he derived from it, . and says: "I consider the communieation as a favour worthy of publie acknowledgment," but does not mention to whom he was obliged for it.

These Ancedotes were indeed almost the sole documents 
he had for the Life of Pope, and they will enable the admirers of that capital specimen of eritical biography to appreciate his skill in forming so interesting and eloquent a narrative from such slight materials. In the lives of Addison, Tickell, and others, he has also made use of the information these Ancedotes contain.

At a subsequent period, the late Mr. Malone was favoured with the free use of the Aneedotes, when engaged in writing the Life of Dryden, and he availed himself of the privilege of making a complete transeript for his own use; in doing this, he has not observed the ehronologieal order of the original, but has classed the anecdotes, bringing all that related to Pope under one class, which he has called "Popiana;" disposing the others under their respective heads. He has added to his transeript a few notes and corrections, and it was these which the late Mr. Beloe had intended to use, when he announced the work for publication some years since.

Having been favoured with a sight of this transeript, since the greater part of the present edition was printed, I am happy to observe that nothing of any material import has escaped me which had occurred to Mr. Malone; and I may add, that some obscurities have been removed, by the light which I have derived from the papers of Mr. Spence.

The manuscripts which have been used for this publieation consist of one bound volume, in octavo, in which the anecdotes had been copied fair from the first loose memorandum papers; this appears to have commeneed in August, 1728 , and finishes in 1737. The variations of this copy I have pointed out, and cited it as MS. B. Besides this; the aneedotes, digested and enlarged in five paper books in folio, each containing two centuries or sections, the first dated 1728, and the last terminating at Pope's death, in 1744. These have been carefully compared with the first 
MIS. memoranda, and with the bound MS. B. above-mentioned, and the important variations noticed.

The additional anecdotes, which 1 lyave thrown into a Supplement, were derived from some loose papers and memorandum books, and seem to erinee an intention on the part of Mr. Spence of eontinuing the Aneedotes down to a later period. All the MSS. were in the hand-writing of Mr. Spenee, and on the first leaf of the Paper Book containing the two first centuries, the following note was written by him in peneil: "All the people well aequainted with Mr. Pope, looked on him as a most friendly, open, charitable, and generous-hearted man;-all the world almost, that did not know him, were got into a mode of having very different ideas of him : how proper this makes it to publish these Aneedotes after my death."-Beneath this is written with a pen, $"$ Left in this drawer beeause so many things in them that were not enter'd in the Vellum MS."

It is obvious that one of the prineipal objects of this collection, must have been to record those things worthy of remark which fell from Pope in the eourse of familiar conversation; but it was subsequently enriehed with curious partieulars, gathered from the same kind of intereourse with other persons of eminence. This gives it a more miseellaneous form, and that variety, which is the very spirit of such a work, and fits it for the intended purpose, a Lounging Book for an idle hour. A complete though brief AutoBiography of Pope may be collected from it, and the most exact record of his opinions on important topies, probably the more genuine and undisguised, beeause not premeditated. but elieited by the impulse of the moment.

In regard to the aceount of the quarrel between Pope and Addison, eontained in the following pages, the necessity must be apparent of examining with eaution this ext-parte 
evidence: I the more anxiously urge this, because I have omitted to comment upon it in the notes. It is with great pleasure I refer the reader to a spirited vindieation of Addison by Mr. Bowles, in a note to the fourth volume of his edition of Pope's Works, p. 41.

In the variety of such a miseellaneous farrago, it might be expected that some trifling and unimportant matter would be found, some things too may have lost their interest by the lapse of time; but I hare thought that most readers would like to make their own seleetion; what may be deemed frivolous and useless by some, would be eonsidered of importanee by others, and the omissions I have ventured upon, are only of such articles as were already printed by Mr. Spence himself, or which were of a nature to be totally unworthy of a plaee, even in a eolleetion of this kind. After all, perhaps I have sinned in giving too much instead of too little. The notes are merely such as oeeurred to me in transeribing the work for the press; more time, or a more convenient access to books, would have enabled me to enlarge them, but I know not how it would have been possible to make two large volumes, as was the intention of Mr. Beloe, whose materials were not near so eopious as my own. The Supplemental Aneelotes, the various additions from Memorandum Papers, and the Letters, were not in his hands, nor eould he have obtained them.

I have mueh pleasure in being the instrument of making this eurious repertory aecessible to the lover of literary anecdote. From a very early period of my life, I earnestly desired to see it, and should have been grateful to any one who had plaeed it in my power, in a form similar to that in which I have now the satisfaction of laying it before the publie.

Bushey, Herts, December $11,1819$. 


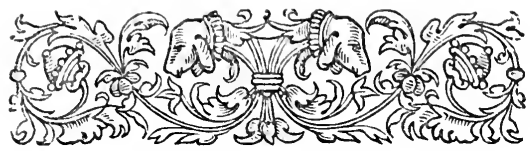

\section{THE LIFE OF THE AUTHOR.}

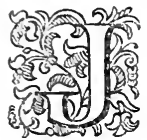

OSEPH SPENCE was born at Kingselere, IIants, on the 25th day of April, 1699. His father, whose name was also Joseph, was Rector of Winnal near Winchester, and afterwards of Clverstoke in the same county. I beliere he died in 1721. By the mother's side Spence was descended from the Neville family, she was a granddaughter of Sir Thomas Lunsford, her maiden name was Mirsbella Collier.

Youmg Spence, whose birth was premature, and who was but a sickly boy, was taken under the protection of Mrs. Fawkener, an opulent relation, and was educated under her eye, until he had reached his tenth year, when he was sent to a school at Mortimer in Berkshire, kept by Mr. Hayeock; from thence he went to Eton College, which lie left in a short time, for some unknown cause; ${ }^{*}$ and went to that of

* There is some reason to think that he may have been disgnsted with the severity of the school discipline at that time, when Dr. George was master, and Dr. Couke (afterwards provost,) propositor. Cole, in a letter to Horace Walpole, among his papers in the British Museum, adrerts to a piece of waggery on the part of Spence, which, if true, gives some colour to the supposition. He says that the vignette at the end of the 17 th dialogue in the first edition of Polymetis, contains a caricature of 1)r. Cooke, under the character of a Pedagogne with an Ass's head. The resemblance of Provost Cooke's features to those of the $\Lambda$ ss, are said to have been too striking not to be instantly perceired by those who knew him.-It is but jnstice to add, that though Cooke was a strict disciplinarian, he was nevertheless not deserving of the satire, if it is true that it was levelled at him, which, after all, when 
Winchester, where he continued until he became a member of New College, Oxford, in 1720. He had been previously entered at Magdalen Hall in the year 1717. His benefactress had fully intended that he should have been amply provided for by her will, but from the neglect or delay of the person employed to draw it up, she died, in 1714, before it was executed, and Spence lost at once his friend and the prospect of succeeding to an estate of $£ 600$ a year. He was then too young to have felt his loss very poignantly, and it is said, that in his after life, he used rather to rejoice at it as an escape, saying, that it might have made him idle and vicious to have been rendered independent of exertion at that age.

In 1722 he became fellow of New College.

In $1724^{*}$ he entered into Holy Orders, and took the degree of A.M. November 2, 1727. And in the succeeding year was chosen Professor of Poetry, the first day he became capable of it, by being made Regent Master.

His fellow collegian, Christopher Pitt, writing to a friend in 1728, says, "Mr. Spence is the completest scholar either in solid or polite learning, for his years, that I ever knew. Besides, he is the sweetest tempered gentleman breathing." About the same time he was presented to the small Rectory of Birchanger in Essex, where he used occasionally to reside with his mother, to whom he always showed extraordinary tenderness and attention. He had now, for the first time, an opportunity of indulging in some degree his natural inclination for gardening, though he could here try his hand only in miniature, and entertained himself with forming his little plot of ground into what he called a Lizard Garden.

Toward the close of the year 1730 he received an invitation to accompany Charles, Earl of Middlesex, $\uparrow$ and made the tour of France and Italy with that amiable young nobleman

Spence's mild disposition is recollected, there may be reason to doubt. It was removed in the third edition of Polymetis, and another vignette of Hermes, the Egyptian Mercury, inserted in its stead.

* In this year he published a Defence of Mr. Woolaston's Notion of a Rule of our Actions.

$\dagger$ Afterwards the second Duke of Dorset. 
in quality of a companion, and not as governor. Their route was by Lyons, Turin, Milan, and Venice to Rome, taking Florence in their way back, and from thence by way of Paris they returned to England. At Lyons he had the happiness of meeting Thomson, the poct, (who was travelling with Mr. Talbot) with whom he had previously contracted an intimacy in England. Spence had spoken very lighly of the loet's Winter on its first publication, in one of the editions of his Essay on the Odyssey, which being a popular book, contributed to make the poem more known. Thomson, who always acknowledged the use of this recommendation, became acquainted with him through the intervention of Dr. Young,* and an intimacy commenced between them, which only terminated with the lamented premature death of the poet, whose amiable temper and benevolent spirit found congenial qualities in Spence. Dr. Warton had seen a letter of Spence's to Mr. Christopher Pitt, earnestly soliciting him to subscribe to the quarto edition of the Seasons, and mentioning a design which Thomson had formed of writing a descriptive poem on Blenheim; a subject which would have shone in his hands.

At Verona he became intimate with the Marquis Maffei, and he thus describes the gaiety and good humour of the then venerable author of Merope. "The Marquis Scipio Maffei, is one of the most eminent and learned men now in Italy. He is an old bachelor, and talks as if the ladies had played him some scurvy tricks in bis youth.-He introduced us to a ball, where he presided, and you cannot conceive how busy the good old gentleman was among the ladies from the eldest to the youngest. He would whisper each as soon as ever she stood still, and was perpetually saying lively civil things to all. Everybody is fond of him, he is a mighty good man, and has done much for the Veronese; among other things, he has just built a very pretty opera-house, with rooms for dancing, conversation, and concerts, all contrived and carried on by him, and at his expense." $\dagger$

* V. Appendix of Letters, No. IV.

$+\mathrm{Mr}$. Spence gave to his mother a detail of his three tours, and the principal occurrences in them in frequent letters, which are still preserved. 
At Venice they enjoyed the Carnival;-and he speaks with rapture of his first view of Naples, where he visited, with enthusiastic reverence, the tomb of Virgil, and plucked a leaf of laurel for his friend Pitt. But Rome was the place he had most eagerly longed to visit, and he talks of it as exceeding the highly coloured picture in his imagination. It was probably here, that the thought was first elicited which gave rise to his magnum opus, the Polymetis; as Gibbon conceived the design of his History, amid the Ruins of the Capitol.-But he did not begin his collection for it until he cane to Florence, his first intention was to have called it Noctes Florentine.

Spence had an eye for the beautiful in nature as well as in art, and describes, with becoming ardour, the lovely Vale of Arno, through which they passed during the Vintage. At Florence their stay was protracted through the winter montlis, and the society and other enjoyments of the place were so delightful to them, that they again saw the carnival here, and were not unwillingly detained by an uncommonly inclement spring, until the month of June, when they repassed the Alps, stayed at Paris a few days, and returned to England at the commencement of July, 1733.

During his absence from England, and only a few days before his return, he was re-elected Poetry Professor for another five years. It is remarkable that Mr. Spence succeeded the Rev. Thomas IVarton, father of the celebrated and worthy author of the Ilistory of English Poetry, who himself afterwards filled the chair; and that each of these three professors were twice elected to the office, and held it for ten years, the longest period the statute will allow.

Previous to going abroad he had published, in 1726, his Essay on Pope's Odyssey, which not only acquired him considerable reputation, but introduced him to the notice of Pope, who is said to have been so well pleased with his book as to seek his acquaintance; this acquaintance soon ripened into friendship, which was lasting and uninterrupted, they ever after, until Pope's death, lived in habits of the strictest intimacy. Dr. Warton had seen "a copy of the 
Essay on the Odyssey,* with marginal observations, written in Pope's own hand, aud generally acknowledging the justness of Spence's observations, and in a few instances pleading, humorously enough, that some farourite lines might be spared." It is probable that the regard and esteem, in which he was held by Pope, may liave been, as Dr. Johnson asserts, one of the causes of his introduction to the notice of the great and powerful, but 1 know not whether he owed his introduction to the Dorset family to him or no.

He describes a short visit he received from Pope, at Oxford. In a letter to his mother from that place, dated September 4,1735 , in which he says, "I have not seen honest Mr. Duck yet, but have had the pleasure of another visit that was wholly unexpected to me. Monday last, after dinner, according to the good sauntering custom that $I$ use here every day, I was lolling at a coffee house half asleep, and half reading something about Prince Eugene and the armies on the Rhine, when a ragged boy of an ostler came in to me with a littleserap of paper not half an inch broad, which contained the following words, 'MIr. Pope would be very glarl to see $\mathrm{Mr}$. Spence at the Cross Inn just now.'-You may imagine how pleased I was; and that I hobbled thither as fist as my spindle-shanks would earry me. There I found him, quite fatigued to death, with a thin face lengthened, at least, two inches beyond its usual appearanee. He had been to take his last leave of lord Peterborough; and came away in a chariot of his lordship's, that holds but one person, for quick travelling. When he was got within abont three miles of Oxford, coming down a hill in Bagly wood, he saw two gentlemen and a lady sitting in distress by the way side. Near them lay a chaise overturned and half broken to pieces; in the fall of which the poor lady had her arm broke. Mr. Pope had the goodness to stop and offer her his chariot to carry

* Among MIr. Spence's papers is a MIS. copy of the two last dialogues of the Essay on the Odyssey, corrected throughout by Pope, and in which some few remarks appear on the blank pages. There is also a copy of the first edition, correeted throughout, but chiefly in what regards punctuation. It was probably these which Dr. Warton saw. 
her to Oxford for help; and so walked the three miles in the very midst of a close sultry day, and eame in dreadfully fatigued. An inn, though designed for a place of rest, is but ill suited to a man that's really tired; so I prevailed on hin to go to my room, where I got him a little dinner, and where he enjoyed himself for two or three hours; and set out in the evening, as he was obliged to do, for Colonel Dormer's, in his way to Lord Cobham's, which was to be the end of his journey."

In 1736 he republished, at Pope's desire, Gorboduc, the celebrated tragedy of Sackville, Earl of Dorset, with a prefatory account of the author. This may probably have been intended as a compliment to his noble pupil. To his habits of intimacy, and almost daily intercourse with Pope, we owe the idea of the present collection of anecdotes, which was begun very soon after the commencement of their acquaintance, and terminated with Pope's death, its chief object was undoubtedly to record his conversation, and the principal incidents of his life.

Benevolence was one of the most distinguishing characteristics of Spence's mind, and it had found a deserving object in Stephen Duck, the thresher and poet, to serve whom he wrote a kind of memoir, which, when he went abroad, he left in the hands of his friend Mr. Lowth for publication, with a sort of Grub-street title as a ruse de guerre; calling himself Joseph Spence, Esquire, Poetry Professor; he afterwards procured for Duck, from the Duke of Dorset, the living of Byfleet, in Surrey; introduced him to the notice of Pope, and continued his countenance and friendship to him through life. Early in the year 1737 he was offered the deanery of Clogher in Ireland, by the Duke of Dorset, who assured him, at the same time, that he might depend upon him for any future preferment which should offer, if he did not think it eligible to accept it; in consequence of this option he declined it. In May of the same year, he accompanied Mr. Trevor in a Tour through Holland, Flanders, and France. It was their intention to have proceeded to Italy, but Mr. Treror was called home to offer himself as a 
candidate for a borough; and after passing the autumn at Blois, and the winter at Tours, they returned to England in February, 1738. He writes thus to his mother from Tours in the preceding December._-" Tours is a very agreeable place. All the towns on the banks of the Loire are said to be so; but the country about 'Tours in particular, is called the garden of France. We eame here with the design of staying only a month; but if we find it as agreeable as it promises to be, we may stay much longer. In the spring we are to pass through Rochelle, Bourdeaux, Montpellier, Marseilles, Avignon, and Lyons, to Geneva, where we shall probably pass the summer, and go, about the end of Oetober, for Italy. Italy is my great favourite; and though I am pleased here, I shall not be perfectly happy till I get into that delightful country of the old Romans; or rather, I shall not be contented till I have finished all, and can come and see you and my sister at Winchester. I own we are delighted when we are abroad; but the greatest and truest satisfaction is when we come home again. I recollect what the Prince of Yallocomia said to me and my dear friend Bob Downes, several years ago at Oxford, where he was shown about as a sight. He said that he wanted for nothing; that he eat and drank well, that he was continually amused with seeing new places; still, said he, there is something wanting, ' for de fader and de moder be alvais in de mind.' He spoke it with much emotion, and put his finger up and patted his forehead all the while he was saying the last sentence, which is a very true one, and very worthy of his highness of Yallocomia." In another letter, he says: "Two or three days since, I had a letter from Mr. Holdsworth, the father of all us travellers; I mean for knowledge, more than for age; with your's I had a letter from good Mr. Duck, who has obliged me very much by the trouble he has taken to disperse my books about, and to pelt poor people, that were easy in their great chairs, with a thing that they would not give a farthing whether they ever read or not. By the time that I shall see you, my little garden at Birchanger will begin to make some shew; and my thoughts now are to come 
and see you at Winchester every other summer, for three or four months; and the other alternate summers to invite you to Birchanger to eat some of my nonpareils; if you and my sister care to take such a journey for a pippin. Though the place is not very magnificent, I can promise you it has quite another air than it had; for, instead of walking into an orchard adorned with nothing but hog-styes, you will go into a garden that will be a little fop, strutting and pretending to be bigger than he is, where, at least, we shall be private and at our ease; unseen ourselves when we have a mind to it, though from the little green plat at one end of it, we may stand like three statues on one pedestal, and look out on a prospect that is no inconsiderable one for Hertfordshire. By that word you may see the pride of my heart, for to say the truth, I don't care to be thought in Essex there, and take all the advantage $I$ can of my neighbourhood to a better county."

In the autumn of 1739 he set out on his last tour to the continent with Henry, Earl of Lincoln.* They went by way of Paris and Lyons to Turin, where they arrived the beginning of October; this city was then a place of great fashionable resort, and the court there accounted one of the politest in Europe. Here they remained a whole year, being detained a month or two longer than was intended, by an accidental sprain Lord Lincoln got in dancing. From hence Mr. Spence writes, to appease the anxiety of his mother, the following affectionate and consolatory letter, which, as it will make the reader better acquainted with this part of his character, I have the less scruple in transcribing.

"You may be wholly out of any concern about my ever coming abroad again. At least the scheme of life $I$ have in my head is quite opposite to any such thought. The large work I have on my hands will take up near four years after I come home before it is all published; and after that $I$ have

* Afterwards Duke of Newcastle.-Mr. Nichols says : "The mortification which Dr. Goddard, afterwards master of Clare Hall, his Grace's Cambridge tutor, felt by this appointment, probably occasioned the extraordinary dedication to the duke, prefixed to his sermons published in 1781." 
some other little things whieh I think at present of publishing; and which, in the leisurely way I shall go about it, merely for my amusement, will take up six years more. I leave you to judge whether I, who was not at all eawer to travel at forty, shall be much inclined to it after fifty; when I shall liave been used too to a retired and settled life for ten years together; and shall have all my plantations growing up about me, which I have already laid out in idea. I mention this particular, because I have found, by the little experienee I have had, that nothing is so apt to attrat one and tie one down to a spot of ground, as a plantation. You may remember how Paul Penton used to go to his nursery every day near Kingselere; and when I was abroal with Mr. Trevor, I believe there was scaree a day that I did not visit Birehanger in imagination. At present I am more busy and more diverted; and yet I often think of it. But I shall have, I hope, a much greater tie to England than any I have mentioned:-I mean your ladyship!-When we are once settled, and in a way of living together, I shall look upon it as my duty, as well as my inelination, to stay with you, and shall not think of stirring a step out of our island, unless you should turn traveller; and then perhaps I might take a little trip into Asia, or to the pyramids of Egypt, purely to attend you thither. The scheme I mentioned to you is the sincere design I have some time had; and, as it has long been growing gradually upon me, is of itself very likely to last; but, with the other consideration joined to it, is, I think, as strong as any human resolution can be. And, indeed after forty, it is high time to think of a settlement, and of getting a steady settled ineome somewhere or other to prevent one's old age being rendered uneasy.-I guess you are already laughing to hear a son of your's talk of being an old man; but that will begin to be a very serious truth in a few years more. Whenever it happens, I don't expect it as a very disagreeable thing; a good easy chair, good company, and the being able to look back upon one's life without any thing to frighten one in it, may make that season, at least, not so terrible: and I don't see why one may not enter upon it as 
agreeably as one goes into a bed, after being tired with the labour of the day. But, lest I should fall into too deep a fit of morality, I will conclude." In another letter, reverting to the same subject, he says-" I want to be setting out; for that is doing something, and looks at least like being nearer coming home. Much as I long again to see Rome, I long more to be with you; and to be settling our little affairs, in order to live together in a comfortable manner the rest of our time; whether that is to be long or short does not signify a great deal; but one would make the time, whatever it may be, agreeable as one can. 'Thank heaven, we are likely, at present, to have enough to live comfortably, and to do some little good round about us; and that I always reckon among the highest pleasures both to you and me." In another place he says- " I don't at all desire wardenships, or indeed any high dignity in the world; and that not out of wisdom, but a love of ease. I am for happiness in my own way, and, according to my notions of it, I might as well, and better, have it in living with you, at our cottage at Birchanger, than in any palace. As my affairs stand at present, 'tis likely that we shall have enough to live quite at our ease; when I desire more than that, may I lose what I have!"

He seems to have been very fortunate in the companions of his travels-Lord Middlesex was a young nobleman of most amiable manners and character; and he found Lord Lincoln so sensible, so agreeable, and obliging, that he says, he thought several times upon the road that he was beginning a second journey with his former friend.-From Turin they went to the baths of Aqui, near Milan, and after remaining there a month, on account of Lord Lincoln's health, they pursued their journey by Florence to Rome.* They stayed at Rome from the beginning of December until the middle of May following, and he had there an opportunity of culti-

* Mr. Spence says, "I find myself at this great city, just as I did the first time I was here; - though it is now a fortnight since I came, I have not yet recovered myself; 'tis all astonishment at the greatness of the things ahout one; and they are so very great, and in such numbers, that one does not know where to fix one's attention, or what to look at first." 
vating the acquaintance of that extraosdinary woman, Larly Mary Wortley Montagu. He says-"1 always desired to be acquainted with Lady Mary, and could never bring it about, though we were so often together in Lonilon; soon after we came to this place her ladyship came here, and in five days I was well aequainted with her. She is one of the most shining charaeters in the world, but shines like a comet; she is all irregularity, and always wandering; the most wise, the most imprudent ; loveliest, most disagreeable; best-natured, eruellest woman in the world, " all things by turus and nothing long.- She was married young, and she told me, with that freedom much travelling gives, that she was never in so great a hurry of thought, as the month before she was married: she scarce slept any one night that month. You know she was one of the most celebrated beanties of her day, and had a vast number of offers, and the thing that kept her awake was who to fix upon. She was determined as to two points from the first, that is to be married to somebody, and not to be married to the man her father advised her to have. The last night of the month she determined, and in the morning left the husband of her father's choice, buying the wedding ring, and seuttled away to be married to Mr. Wortley." It was here that Mr. Spence learned those particulars from her which are reeorded in the Aneedotes.

From Rome they went to Reggio, 'opera hunting,' as Mr. Spence expresses it, and here they found $\mathrm{Mr}$. Horace Walpole very ill with a quinsey.- " About three or four in the morning I was surprised with a message, saying, that Mr. Walpole was very mueh worse, and desired to see me; I went and found him searee able to speak. I soon learned from his servants that he had been all the while without a physician, and had doetored himself; so I immediately sent for the best aid the place would afford, and despatehed a messenger to the minister at Florence, desiring him to send my friend Dr. Coechi. In about twenty-four hours I had the satisfaction to find Mr. Walpole better; we left him in a fair way of recovery, and we hope to see him next week at 
Venice. I had obtained leave of Lord Lincoln to stay behind some days if he had been worse. You see what luck one has sometimes in going out of one's way. If Lord L. had not wandered to Reggio, Mr. Walpole (who is one of the best natured and most sensible young gentlemen England affords) would have, in all probability, fallen a sacritice to his disorder.

From Reggio they went to Venice. After staying there about two months they passed by sea from Genoa to the south of France. They spent a month at Montpellier and Vigan, where Lord Lincoln's excellent mother had lived two or three years with her children "in one of the finest airs in the world (says Mr. Spence); in spite of which she lost her eldest son there, but brought off my lord stronger and in better health, though I doubt not his friends will be surprised to see bow much stronger and better he is grown now. 'Tis said that the name of Lady Lincoln is blest by all the good people in the Cevennes, among whom she did a world of good." From thence they went to Paris, and, after a few weeks stay there, returned to England in November, 1742.

In this year he was presented by his college to the rectory of Great Horwood, Bucks, and succeeded Dr. Holmes as Regius Professor of Modern History. From this time he resided chiefly in London for some few years; but his health, since his return from abroad, having been precarious, he was advised by his friends to abandon his studies; and, however disagreeable the remedy, he would, probably, have listened to their entreaties. The Polymetis which had now occupied his attention for several years, for which he had made very large collections, and had obtained very large and numerous subscriptions, was about to have been abandoned; had not Dr. Mead interposed and preseribed to him a middle course, advising him to apply moderately, and at short intervals, to his literary pursuits rather than entirely and at onee to abandon them: he followed this friendly advice, and it had the desired effeet.*

* Soon after the rebellion in $1745, \mathrm{Mr}$. Spence wrote and pub. lished an occasional paper under the title of "Plain Matter of 
IIis taste and inclinations led him very early to a love for the country and rural improvement. Ornamental gardening was then taking a direction (puite opposite to the old and formal methods of the Freneh, Duteh, and ltalians. Walpole, who had paid mueh attention to its progress, hats proved that Kent was the first artist who diffused the prevailing taste of landscape gardening, and says, that Pope undoubtedly contributed to form Kent's taste.* It is most probable that Spence's enthusiasm for this elegant art was strengthened, if not derived from his intimacy with the poet. After the publication of his Polymetis, in 1747, by which he had realized upwards of fifteen hundred pounds, he entertained thoughts of indulging his propensity, by the purchase of a small house and a few acres of ground in the country. Having casually mentioned this intention to his friend Lord Lineoln, he very generously offered him, as a gift for his life, a house of this kind at Byfleet in Surrey, in the immediate vicinity of his seat at Oatlands. Thither Spence removed in the year 1749 , and immediately proceeded to turn his fields into pleasure grounds, and to plant and adorn the fice of the country round his abode. From this time to the end of his life, rural improvement became his favourite amusement; he expended a great part of the profits arising from his Polymetis in embellishing his little seat, and aequired much reputation by the judgment he displayed. He was from time to time consulted by his friends and others when anything of the kind was meditated; his suggestions were listened to with respect, and generally followed without deviation. Walpole, whose opinion will be allowed to have much weight

Fact, or a short Review of the Reigns of our Popish Princes since the Reformation; in order to show what we are to expect if another should happen to reign orer us." I am not sure that more than one number was published.

* "Mr. Kent was the sole beginner of the present National Taste in Garlening. Witness his works at Kensington Gardens below Bayswater.-And at Lord Burlington's at Chiswick; the latter in Uetober, 1733. Mr. Scot has a drawing of the first thing done that way there, of Kent's. He had shown his skill before at Lord Cobham's, and by a design for Mr. Pope's Mfount."-From Mr. Spence's Pupers. 
on this subject, compliments him upon his taste and zeal for the reformed style of picturesque gardening. It is most probable that his health was improved and his life prolonged by this happy alternation of activity in his favourite pursuit, and repose in his literary trifling. He seems to have intended the publication of an Essay on the subject of Gardening in all ages, to have been entitled "Tempe:" the collections he left in manuscript on the subject, evince that it was his darling, though not his exclusive pursuit to the day of his death.

Upon the translation of Dr. Trevor, Bishop of St. David's, to the See of Durham, he intimated to Mr. Spence that he should have the first prebend in that see which fell to his gift, and his promise was realized in 1754 . From this period Mr. Spence divided his time chiefly between Durham and Byfleet, contenting himself with very moderate enjoyments and gratifications ; and seems to have used his fortune, which was now ample compared with his desires, as if he stood possessed of it as steward only for the service of mankind, and constantly applied a considerable portion of it to purposes of charity. As he never resided upon his living of Great Horwood, he thought it part of his duty to make an annual visit to his parishioners, and gave away considerable sums of money to the distressed poor, placing out many of their children as apprentices, and doing other acts of beneficence. Finkalo, or West Finchale Priory near Durham, was part of Mr. Spence's prebendal estate; this spot, which had been the scene of the miracles of St. Godric, who from an itinerant merchant turned hermit, and wore out three suits of iron, was a favourite retreat with him; and he here again exercised his taste and skill in his much loved art.

In his selection of objects for the exercise of his benevolent propensities it was natural for him to place indigent men of letters in the first rank.

In the year 1754* he published "An Account of the Life,

* In the preceding year, he had caused to be printed for the diversion of a few friends and his own solace, 'Moralities,' under 
Character, and Poems of Mr. Blacklock," and obtained a large subseription to an edition of the poems of that amiable and interesting eharaeter; which materially assisted the views of his friends in procuring him an edueation suitable to his genius and views in life. Blacklock testified his obligations to Mr. Spence, to whom he was personally unknown, in a poetical epistle written from Dumfries, in 1759, eoncluding thus :

"If to your very name, by bounteous Ieav'n, Such blest, restoring influence has leen giv'n, How must your sweet approach, your aspect kind, Your soul-reviring converse warm the mind!"

Spence's benevolence was most liberal and unconfined; distress of every sort, and in every rank of life, never preferred its claim to his attention in vain: and he is described by one who knew him well, to have had a heart and a hand ever open to the poor and the needy.

It was this feeling that urged him to befriend the worthy Stephen Duck, and at a subsequent period he found another meritorious object in Robert Hill, the learned tailor, to serve whom he drew up that ingenious memoir and parallel, which his friend Horace Walpole, to assist his generous purpose, caused to be printed at his private press at Strawberry IHill in 1757 . It was afterwards reprinted with other pieces of Mr. Spence in Dodsley's collection of Fugitive Pieces.

Besides these, at an earlier period he had taken by the hand the ingenious Robert Dodsley, and was one of the earliest patrons of that deserving and worthy man. In one of Curll's scurrilous attacks upon Pope he is thus introduced:

the feigned appellation of Sir Harry Beaumont, a name which he had likewise adopted in his "Crito, a Dialogue on Beauty," and his translation of the Jesuit Attiret's " Letter on the Royal Gar. dens at Pekin ;" the two latter were re-published in Dorlsley's Collection of Fugitive Pieces, in 1765.-Some Account of the Antiquities at Herculaneum were communicated by him to the Royal Society, in $175 \pi$, and published in their 'Transactions, Vol. 48. 
"'Tis kind indeed a livery muse to aid

Who scribbles Farces to augment his trade,

Where you and Spence and Glover drive the nail,

The Devil's in it if the plot should fail.'

Dodsley had been servant to Miss Lowther, and published his first poetical effusions under the title of "The Muse in Livery." He had the prudence to make a good use of the profits of his poems, and a successful farce, and in process of time became one of the most eminent booksellers of the Metropolis. His gratitude and affectionate friendship for his early patron continued through life. And Spence had the melancholy satisfaction of paying the last kind office to his humble friend, for he died on a visit to him at Durham, in the year 1764 .

In the latter part of his life Mr. Spence made several excursions to the most romantic parts of our island. I find the journal of one to the Peak in Derbyshire, in 1752, in which he appears to have visited everything remarkable in his rout: his observations are chiefly confined to the picturesque appearance of the country, the antiquities, architecture, works of art, \&c. And in 1758 he accompanied his friend Dodsley in a long tour to the north. On their road they visited the Leasowes and stayed a week there;-Shenstone thus notices this visit in a letter to his friend Mr. Graves. "I have seen few whom I liked so much, upon so little acquaintance, as Mr. Spence: extremely polite, friendly, cheerful, and master of an infinite fund of subjects for agreeable conversation. Had my affairs permitted, they had certainly drawn me with them into Scotland; whither they are gone for about a month upon a journey of curiosity."In another letter, he says, "Mr. Spence is the very man you would like, and who would like you of all mankind. He took my Elegies with him into Scotland, and sent them back on his return, with a sheet or two of criticisms, and a handsome letter.-How much am $\mathrm{I}$ interested in the preservation of his friendship!- and yet such is my destiny (for I can give it no other name), I have never wrote to him since. This impartiality of my neglect, you must accept yourself as some 
apology :-but to proceed; Mr. Spence chose himself an oak here for a seat, which $\mathrm{I}$ lave inseribed to him :*

\author{
EXIMIO. NOSTRO. CRITOXI. \\ CVI. DICARI. VEILET. \\ MVSARVM. OMNIYM. ET, GRATIARVM. CHORVS. \\ DIC IT IMITITI.
}

This journey of $\mathrm{Mr}$. Spence is agreeably deseribed in a letter to Shenstone, printed in Inull's collection. $\dagger$

In the year 1764, Mr. James Ridley, the son of his old friend Gloster Ridley, gave an accurate and interesting delineation of his character and retreat, in his Tales of the Genii; Spence is meant by Phesoi Ecneps, the Derrise of the Groves. A panegyrieal letter to Mr. Rilley, on the occasion, by MIr. Spence, is printed in the collection of letters abore cited.

The last of his literary labours was the agreeable task of preparing for the press " lemarks and Dissertations on Virgil, with some other classical observations," by his friend Holdsworth, to which were added, notes and additional remarks of his own. His health was now in a declining state, and though the greater part of this volume was printed in 1767 , it was not published until the beginning of 1768 , by the care of his friend Dr. Lowth, who had communicated a few remarks, and who made the table of Errata, which Mr. spence was then not able to do.

He had executed his will while on a visit to his amiable friend at Sedgefield in the preceding autumn, and added a codicil, remembering a faithful servant, with his own hand, in the spring. He had appointed Dr. Ridley, Dr. Lowth, and his nephew the Rev. Edward Rolle, executors; leaving

* I find this inseription among Mr. Spence's Papers in rather a cifierent form.

JOSEPHO, SPEXCE.

CUI. SEDEM. HINC. DICARI. VELLET.

MESARLM. OMNIUM. ET GRATIARUM, CHORUS.

† Vol. i. p. 278 .

DICAT. AMIITI. 
a few trifling legacies and benefactions, but it conld hardly be expected that he should have much to leave. His sister and two brothers died some years before him.

Besides the literary productions already noticed, Mr. Spence published some occasional verses; particularly the concluding copy in the Oxford collection, on the Birth of the Prince of Wales; an Epistle from a Swiss Officer to his Friend in Rome, in Dodsley's Museum; and some few others, which are to be found in Mr. Nichols's collection. But verse was not Mr. Spence's talent, though he wrote much for his amusement; and Dr. Lowth acted with truly friendly regard to his reputation, when he decided that not a verse which he left behind him should be published.

Dr. Johnson has been thouglit to speak with prejudice of Spence when he says that he was " a man whose learuing was not very great, and whose mind was not very powerful;" but I must in candour acknowledge that there is no appealing from this judgment: and nothing can be more true than what follows. "His criticism, however, was commonly just; what he thought, he thought rightly, and his remarks were recommended by coolness and candour. In him Pope had the first experience of a critic without malevolence, who thought it was as much his duty to display beauties, as expose faults; who censured with respect, and praised with alacrity."-If we regard the state of criticism at the period the Essay on the Odyssey appeared, no small degree of credit will attach to its author. At that time we had few things which might compare with it ; and it must be confessed that, the period of its publication considered, Dr. Warton has not over-rated its merits, in having pronounced it to be "a work of true taste." A later panegyrist has asserted, that it is, "for sound criticism, and candid disquisition, almost without a parallel?" It is hardly possible to conceive, as the same writer fondly conjectures, "that Dr. Johnson's frigid mention of Spence, might arise from a prejudice conceived against, him on account of his preference of blank verse to rhyme, in that essay?"

Of the Polymetis, Gray has spoken very slightingly in his 
letters : one of his objections is, that the sulject is illustrated from the Roman, and not from the Greek writers; which Dr. Lowth has ingeniously endeavoured to obviate, by observing, that "Spence has not performed what he never undertook; nay, what he expressly did not umlertake." lBut does this argue that the subject would not have been better illustrated from them, as in some degree the fountain head and source of the Roman my thology?-The work appears to have been highly acceptable to the public, and to have met with all possible suceess; a seeond edition was soon called for, and a third was printed in $177 t$. I believe it is not many years since, that it was thought a fourth edition might be acceptable to the public. An abridgment was also made of it, which was long a popular book in our schools, until the more copions and useful dictionary of Dr. Lempriere superseded it. Whatever may have been thought of the Polymetis* at the time of its publication, it is certain that the graphic illustrations are but very mediocre, and it has been justly observed, that "it has sunk by its own weight, and will never rise again."-Upon this work, and the Essay on Pope's Odyssey, Spence's literary fame has hitherto rested; that he enjoyed a large share of it while living, there is ample testimony: but the style of dialogue in which he wrote has become deservedly unpopular, and it does not appear that he is likely to be so fortunate in his appeal to posterity.

Spence was in person below the middle size, his figure spare, his comntenance benignant, and rather handsome, but bearing marks of a delicate constitution. As in his childhood he had been kept alive by constant care and the assistance of skilful medical aid, he did not expect that his life would have been protracted beyond fifty years. But he possessed

* I cannot resist this opportunity of mentioning with gratitude the pleasure I derived from the very elegant little manual published many years since in France, by Mons. Millin, under the title of "Galerie Mythologique," in which the subjeet is illustrated by the remains of ancient art. 'This work, alone, would serve to prove how much more completely the subject is now understool; the labours of German sholurs and antiquaries, then and since, have left notling to be desired in this respect. 


\section{xxxii LIFE OF THE AUTHOR.}

those greatest of all blessings, a cheerful temperament, a constant flow of animal spirits, and a most placable disposition. These, with the happy circumstances in which he was placed, and the active nature of his gardening amusements, prolonged its date to his 70 th year: when he was unfortunately drowned in a canal in his garden at Byfleet. Being, when the accident occurred, quite alone, it could only be conjectured in what manner it happened; but it was generally supposed to have been occasioned by a fit, while he was standing near the brink of the water. He was found flat upon his face at the edge, where the water was too shallow to cover his head, or any part of his body. Thus terminated the life of Spence, of whom it was soon after said with strict justice, as Charles the Second said of Cowley :- "That he left not a better man in England behind him;" and though he may not be placed in the first rank of eminence as a writer, yet will his name be venerated for qualities which are something more and better. It is surely enough to be remembered

"For every virtue under heaven."

He was buried in the parish church of Byfleet, and a neat mural tablet was inscribed to his memory by his executors, with the following tribute to his virtues, from the pen of his excellent friend Lowth-

\footnotetext{
HERE LIE THE REMAINS OF

JOSEPH SPEXCE, M.A.

REGIUS PROFESSOR OF MODERX HISTORY IX THE CXIVERSITY OF OXFOBD,

PREBENDARY OF DURHAM,

AND RECTOR OF GREAT HORWOOD, BCCKS.

IN WHOM LEARNING, GEXIUS, AND SHINING TALENTS

TEMPERED WITH JUDGMENT,

AND SOFTENED BY THE MOST EXQUISITE SWEETXESS OF MANXER,

TERE GREATLY EXCELLED BY HIS HUMANITY;

EVER READY TO ASSIST THE DISTRESSED

BY CONSTANT AND EXTENSIVE CHARITY TO THE POOR,

AND BY TNBOUNDED BENEVOLENCE TO ALL :

HE DIED AUG. 20, 1768 ,

IN THE 70TH YEAR OF HIS AQE.
} 


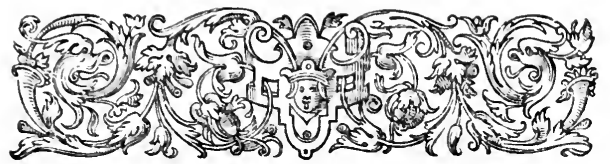

\section{SPENCE'S ANECDOTES.}

\section{SECTION I. 1728-30.}

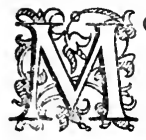

OST little poems should be written by a plan: this method is evident in Tibullus, and Ovid's Elegies, and almost all the pices of the ancients.-Horace's Art of Poetry was probably only fragments of what he designed; it wants the regularity that flows from the following a plan; and there are several passages in it that are lints only of a larger design. This appears as early as at the twenty-third verse.

"Denique sit, quod vis, simplex duntaxat et unum,"

which looks like the proposal of a subject, on which much more was necessary to be said; and yet he goes off to another in the very next line--Pope.

A poem on a slight subject, requires the greater eare to make it considerable enough to be read. [He had been just speaking of his Dunciad.] $-P$.

Garth talked in a less libertine manner, than he had 
been used to do, about the three last years of his life. He was rather doubtful, and fearful, than religious.* It was usual for him to say: "That if there was any such thing as religion 'twas among the Roman Catholics." Probably from the greater efficacy we give the Sacraments. He died a Papist; as I was assured by Mr. Blount, who carried the Father to him in his last hours. He did not take any care of himself in his last illness ; and had talked, for three or four years, as one tired of life: in short, I believe he was willing to let it go. $-P$.

Wycherley died a Romanist, and has owned that religion in my hearing.- It was generally thought by this gentleman's friends, that he lost his memory by old age; it was not by age, but by accident, as he himself told me often. He remembered as well at sixty years old, as he had done ever since forty, when a fever occasioned that loss to him. $-P$.

Prior was not a right good man. He used to bury himself, for whole days and nights together, with a poor mean creature, and often drank hard. He turned from a strong whig (which he had been when most with Lord Halifax) to a violent tory; and lid not eare to converse with any whigs after, any more than Rowe did with tories. $-P$.

Sir John Suckling was an immoral man, as well as debauched. The story of the French cards $\uparrow$ was told me by

+ Note by Mr. Spence from MS. B.-Garth sent to Addison (of whom he had a very high opinion) on his death-bed, to ask him whether the Christian religion was true.-Dr. Youxg from Addi. son himself, or Tickell, which is mueh the sume.

+ His getting certain marks, known only to himself, affixed to all the cards that came from the great makers in France.-Spence. 
the late Duke of Buekingham; and he had it from old Lauly Dorset herself. $-P$.

That lady took a very odl pride in boasting of her familiarities with Sir John Suckling. She is the Mistress and Goddess in his poems; and several of tlose pieees were given by herself to the printer. This the Duke of Buckingham used to give as one instance of the fondhess she had to let the work know how well they were acquainted. $-P$.

Sir John Suekling was a man of great vivaeity, and spirit. He died about the beginning of the Civil War; and his death was oeeasioned by a very meommon aeeident. He entered warmly into the King's interests; and was sent over to the eontinent by him, with some letters of great consequence, to the Queen.* He arrived late at Calais; and in the night his servant ran away with his portmanteau, in which was his money and papers. When he was told of this in the morning, he immediately inquired which way his servant had taken, ordered his horses to be got ready instantly, and in pulling on his boots, found one of them extremely uneasy to him : but, as the horses were at the door, he leaped into his saddle, and forgot his pain. He pursued his servant so cagerly, that he overtook him two or three posts off; recorered his portmanteau; and, soon after, complained of a vast pain in one of his feet, and fainted away with it. When they came to pull off his boots, to fling him into bed, they found one of them full of blood. It seems his serrant, (who knew his master's temper well, and was sure he would pursue him as soon as his

* Henrietta Maria went to Holland about the end of February, 1642; and returned in February, 1643. 
villany should be discovered,) had driven a nail up into one of his boots, in hopes of disabling him from pursuing him. Sir John's impetuosity made him regard the pain only just at first; and his pursuit turned him from the thoughts of it for some time after: however, the wound was so bad, and so much inflamed, that it flung him into a violent fever, which ended his life in a very few days. 'This incident, strange as it may seem, might be proved from some original letters in Loud Oxford's collection. $-P$.

It was a general opinion, that Ben Jonson and Shakespreare lived in enmity against one another. Betterton has assured me often, that there was nothing in it: and that such a supposition was founded only on the two parties, whieh in their lifetime listed under one, and endeavoured to lessen the character of the other mutually.-Dryden used to think that the verses Jonson made on Shakespeare's death, had something of satire at the bottom; for my part, I can't discover anything like it in them.* $-P$.

Lord Rochester was of a very bad turn of mind as well as debauched. [From the Duke of Buckingham and others that knew lim. $]-P$.

Mr. Pope's life, that was so valuable to the world, was in danger several times; and the first, so early as when le was a child in eoats. A wild cow that was driven by the place where he was at play, struck at him with her horns ; tore off his hat, wounded him in the throat; beat him down, and trampled over him.-Mrs. Racket, his sister, who was older than him; and was by when it happened.

* Ben Jonson was found reading Horace by the great Camden, and it was he who sent him to the University of Cambridge.-Mr. Pore. (Addition from MS. B.) 
Ifis second eseapewas when he was about two-anul-twenty. He was travelling in a coateh by night; and with a eoalchman that did not know the roat so well as he should have done. They were to cross the Thames: and the eoachman drove into the water: but after they were a little way in, the horses stoppert short; and all his swearing and whipping could not make them stir a foot on. Some passengers that happened to come by just in the leeight of his enleavouring to force them to go on, ealled to the man, and told him that his horses had more sense than himself; that the 'Thames. was not fordable there, that they were just on the lirink of a hole twice as deep as the coach; and that if they hat proceeded a step farther, they must all have been lost. So he drew back, and got out of the river again, and they were very glad to lie at a little alehouse on the bank they hat just quitted. $-P$.

His third danger was in a coach too; with six spirited horses. They took fright, rum away; and overtmmed the eoach, with him only in it, into a diteh full of water. He was almost suffocated there; and broke the glass with his hand to let in the air: but as the coach sunk deeper the water gained very fast upon him; and he was taken ont but just time enough to save him from being drowned.-P.

Beside these, his perpetual application (after he set to study of himself) rednced him in four years time to so bar a state of health; that, after trying physicians. for a good while in vain, he resolved to give way to his distemper; and sat down calmly, in a full expectation of death in a short time. Under this thought he wrote letter's to take a last farewell of some of his more partienlar friends; and anong the rest, one to the Abbe Southeote. The Albbe was ex- 
tremely concerned, both for his very ill state of health, and the resolution he said he had taken. He thought there might yet be hopes; and went immediately to Dr. Radcliffe, with whom he was well acquainted, told him Mr. Pope's case; got full directions from him and carried them down to Mr. Pope in Windsor Forest. The chief thing the doctor ordered him, was to apply less; and to ride every day: the following his advice soon restored him to his health.* $-P$.

It was about twenty years after this, that Mr. Pope heard of an Abbey's being like to be vacant in the most delightful part of France, near Avignon: and what some common friend was saying would be the most desirable establishment in the world for Father Southeote. Mr. Pope took no farther notice of the matter on the spot; but sent a letter the next morning, to Sir Robert Walpole, (with whom he hal then some degree of friendship) and begged him to write a letter to Cardinal Fleury to get the Abbey for Southcote. The affair met with some delay (on account of our court having just then settled a pension on Father Courayer) but succeeded at last, and Southeote was made Abbot. $-P$.

-Waller, Spenser, and Dryden, were Mr. Pope's great favourites, in the order they are named, in his first regding till he was about twelve years old.- $P$.

Mr. Pope's father (who was an honest merchant, and dealt in Holland's wholesale) was no poet, but he used to set him to make English verses when very young. He was pretty difficult in being pleased; and used often to

+ This was when Mr. Pope was about seventeen, and consequently about the year 1705 . 
send him back to new turn them. "These are not good rhimes ;" for that was my husband's word for verses.- $M r$. Pope's mother.

Mr. Pope said that he was seven years unlearning what he had got (from about twenty to twenty-seren.)-He should have travelled had it not been for his ill-health (and on every oeeasion that offered, had a desire to travel, to the very end of his life.) His first education was at the seminary at Twiford near Winehester.- $P$.

Mr. Addison wrote a letter to Mr. Pope, when young, in which he desired him not to list himself under either party: "You," says he, " who will deserve the praise of the whole nation, should never content yourself with the half of it." $-P$.

In speaking of comparisons upon an absurd and unnatural footing, he mentioned Virgil and Homer; Corneille and Racine; the little ivory statue of Polyeletes and the Colossus. Magis pares quam similes? " $\mathrm{Ay}$, that's it in one word." $-P$.

There was such a real character as Morose in Ben Jonson's time. Dryden somewhere says so ; ${ }^{*}$ and Mr. Pope had it from Betterton, and he from Sir William Davenant, who lived in Jonson's time and knew the man.What trash are his $\uparrow$ works taken all together. $-P$.

One might diseover schools of the poets, as distinctly as the schools of the painters; by much converse in them, and a thorough taste of their manner of writing. (He had been just speaking of Voiture and Sarazin.) $-P$.

Boileau, the first poet of the French, in the same manner

* In his Essay on Dramatic Poetry.-Spence.

† i. e. Ben Jonson's, as I collect from a note in MS. B. Editor. 
as Virgil of the Latin: Malherbe, longo intervallo, the second. Racine's character is justness and correctness : Corneille's, passion and life: Corneille stumbles oftener and has greater excelleneies. $-P$.

The design of the Memoirs of Seriblerus was to have ridieuled all the false tastes in learning, under the character of a man of eapaeity enough; that had dipped into every art and science, but injudiciously in each. It was begun by a club of some of the greatest wits of the age. Lord Oxford, the Bishop of Roebester, Mr. Pope, Congreve, Arbuthnot, Swift, and others. Gay often held the pen; and Addison liked it very well, and was not disinclined to come in to it. The Deipnosophy consisted of disputes on ridiculous tenets of all sorts: and the adventure of the Shield was designed against Dr. Woodward and the Antiquaries. It was Anthony Henley who wrote " the life of his musie master Tom 1urfey;" a chapter by way of episode.-It was from a part of these memoirs that $\mathrm{Dr}$. Swift took his first hints for Gulliver. There were pigmies in Schreibler's travels; and the projects of Laputa.-The design was earried on much farther than has appeared in print; and was stopped by some of the gentlemen being dispersed or otherwise engaged (about the year 1715.) See the memoirs themselves. $-P$.

A study should be built, Jooking east; as Sir Henry Wotton says in his little piece on Architecture; which is good enough, at least the best of his works. $-P$.

The method of learning a number of incoherent words, backward or forward, by fixing them one by one to a range of pictures, very easy ; but even according to G. Markham, scarce of any manner of use.- $P$. 
That Idea of the Pieturesque, from the swan just gilded with the sun anidst the shade of a tree over the water.-P. [on the Thetmes.]

A tree is a nobler object than a prinee in his coronation robes.- Education leads us from the admiration of benuty in natural objects, to the admiration of artificial (or eustomary) exeellence.-I don't doul,t but that a thorough-bred lady might admire the stars, because they twinkle like so many caudles at a birth-night.-- $P$.

As L'Esprit, La Rouchefoneault, and that sort of people, prove that all virtues are disgnised vices; I would engage to prove all viees to be disguised virtues. Neitler, indeed, is true: but this would be a more agreeable subject; and wonld overturn their whole scheme. $-P$.

Arts are taken from nature; and after a thousand vain efforts for improvements, are best when they return to their first simplicity. $-P$.

A sketeh or analysis of the first prineiple of cach art, with their first consequences, might be a thing of most exeellent service.- Thus, for instance, all the rules of architecture would be reducible to three or four heads. The justness of the openings, bearings upon bearings, and the regularity of the pillars. $-P$.

That which is not just in buildings, is disagreeable to the eye; (as a greater upou a slighter, de.) This he called " the reasoning of the eye." $-P$.

In laying out a garden, the first thing to be considered is the genius of the place: thus at Riskins, for example, Lord Bathurst shonld have raised two or three mounts; beeause his situation is all a plain, and nothing can please without rariety. $-P$. 
I have sometimes had an idea of planting an old gothic cathedral in trees. Good large poplars with their white stems (eleared of boughs to a proper height) would serve very well for the columns; and might form the different aisles or peristiliums, by their different distances and heights. These would look very well near; and the dome rising all in a proper tuft in the middle, would look as well at a distance. $-P$.

Cowley's allowance was, at last, not above three hundred a year. He died at Chertsey; and his death was oceasioned by a mean accident, whilst his great friend, Dean Sprat, was with him on a visit there. They had been together to see a neighbour of Cowley's; who (according to the fashion of those times) made them too welcome. They did not set out for their walk home till it was too late; and had drank so deep, that they lay out in the fields all night. This gave Cowley the fever that carried him off. The parish still talk of the drunken Dean. $-P$.

The Virtuoso of Shadwell does not maintain his character with equal strength to the end: and this was'that writer's general fault. Wycherley used to say of him: "That he knew how to start a fool very well; but that he was never able to run him down." $-P$.

Gay was a great eater. "As the French philosopher used to prove his existence by cogito ergo sum, the greatest proof of Gay's existence is edli ergo est." [Congreve in a letter to Pope.]-MS. $B$.

It is a very easy thing to devise good laws: the difficulty is to make them effeetive.-The great mistake is that of looking upon men as virtuous, or thinking that they can be made so by laws: and consequently the greatest art of 
a politician, is to render viees serviecable to the cause of virtue.-Lord Bolinglbolie.

As to our senses, we are made in the best manner that we possibly could.-If we were so formed as to see into the most minute eontiguration of a post, we should break our shins against it.- We see for use, and not for euriosity. - Was our sight so fine, as to picree into the internal make of things, we should distinguish all the tine duets and the contrivanees of each eanal, for the conveyance of the juices in every one of those leaves: but then we slould lose this beautiful prospect: it would be only a heap and confusion to the eye. $-B$.

Cudworth in Theologieal Metaphysies, Locke in proper Metaphysies, and Newton in Physies, are read as the first books of their kind in several foreign universities. The eharaeter of our best English writers gets ground abroad very mueh of late.- $B$.

Lord Baeon in his Norum Organum has laid down the whole method that Deseartes afterwards followed. $-B$.

Dryden has assured me that he got more from the Spanish erities alone, than from the Italian and French, and all other eritics put together.-Just before I went to Utreteht I learnt the Spanish language in three weeks time; so as to be able to read and answer letters. $-B$.

The editorial critieism was very useful and neeessary in Erasmus and the earlier revivers of learning; but the carrying it on without merey by the later eritics, has only served to puzzle the text.-B.

After all, it is Nicholas the Fifth to whom Europe is obliged for its present state of learning. $-B$.

At Paris they have a stated set of paradoxical orations. 
The business of one of these was to show, that the history of Rome, for the four first centuries, was all a mere fiction. The person engaged in it proved that point so strongly and so well, that several of the audience as they were coming out, said those who had proposed that question played booty; and that it was so far from a paradox, that it was a plain and evident truth.*-B.

As to the general design of Providence, the two extremes of vice may serve (like two opposite biases) to keep up the balance of things.-Pope.

2 When we speak against one eapital vice, we ought to speak against its opposite: the middle betwixt both is the point for virtue.- $P$.

The first epistle is to be to the whole work, what a scale is to a book of maps; and in this, I reckon, lies my greatest difficulty: not only in settling and ranging the prarts of it aright, but in making them agreeable enough to be read with pleasure. [This was said in May, 1730, of what he then used to eall his Moral Epistles, and what he afterwards called his Essay on Man. He at that time intended to have included in one epistle what he afterwards addressed to Lord Bolingbroke in four.] $-P$.

Perhaps we flatter ourselves when we think we can do much good: it is mighty well, if we can just amuse and keep out of harm's way. [This was after he had been

* This article may have reference to M. de Pouilly's " Dissertation sur l'incertitude de l'Histoire des quatres premiers siecles de Rome," which was read at the Academy of Belles Lettres, at Paris, Dec. 15, 1722; it is published in the sixth volume of the Memoirs of the Academy, and answered by Sallier in several memoirs published in the same work in the course of the years 172:3, 1724, and 1725.-Editor. 
speaking coldly of his moral work; and had been pressed to go on with it, on account of the good it might do to mankind.] $P$.

Wycherley was a very handsome man. IIis acquaintance with the famous Duchess of Cleveland commenced oddly enough. One dar, as he passed that duchess's coach in the ring, she leaned out of the window, and eried out loud enongh to be heard distinctly by him: "Sir, you're a rascal: youre a villain !" Wycherley from that instant entertained hopes. Ile did not fail waiting on her the next morning: and with a very melancholy tone begged to know, how it was possille for him to have so much disobliged her (irace? They were very good friends from that time; ret, after all, what did he get by her? He was to lave travelled with the young Duke of Richmond; King Charles gave him, now and then, a hundred pounds, not often.--P.

Wycherley was tifteen or sixtecn when he went into France; and was aequainted there with Madame de Rambonillet, a little after Balzae's death.-- Ife was not unvain of his face. That is a fine portrait which was engraved by smith for him in 1703. He was then about his grand elimacteric; but sat for the pieture from which it was taken when he was about twenty-cight. The motto to it "Quantum mututus ab illo" was ordered by himself; and he used to repeat it sometimes with a melancholy emplkisis.-- $P$.

We were pretty well together to the last: only his memory was so totally bad, that he did not remember a kindness done to him, eren from minute to minute. He was peevish too latterly ; so that sometimes we wore out a little, and sometimes in. He never did any unjust thing to me 
in his whole life; and I went to see him on his deathbed. $-P$.

Wyeherley's nephew, on whom his estate was entailed (but with power to settle a widow's jointure), would not consent to his selling any part of it; which he wanted mueh to do, to pay his debts, about a thousand pounds. He had therefore long resolved to marry ; in order to make a settlement from the estate, to pay off his debts with his wife's fortune: and " to plague his damned nephew," as he used to express it. This was just about the time he had intended for it: as he only wanted to answer those ends, by marrying; and dreaded the ridieule of the world for marrying when he was so old. After all the woman he did marry, proved a cheat; was a east mistress of the person who reeommended her to him; and was supplied by him with money for her wedding clothes. After $\mathrm{Wy}_{\mathrm{y}}$ eherley's death, there were law-quarrels about the settlement. Theobald was the attorney employed by her old friend; and it was by this means that Theobald came to have Wyeherley's papers in his hands.-P.

Wycherley had this odd partieularity in him, from the loss of his memory; that the same chain of thought would return into his mind, at the distance of two or three years, without his remembering that it had been there before. Thus perhaps he would write one year, an Encomium on Avariee (for he loved paradoxes) : and a year or two after, in Dispraise of Liberality: and in both, the words only would differ; and the thoughts be as mueh alike as two medals of different metals out of the same mould. $-P$.

Oldham is a very indelicate writer: he has strong rage, but it is too much like Billingsgate.-Lord Rochester 
hat much more delicacy, and more knowledge of mankind. $-P$.

I read Chancer still with as much pleasure as almost any of our poets. He is a master of manners, of deseription, and the first tale-teller in the true enlivened natural way. $-P$.

Fenton is a right honest man. He is fat and indolent, a very good scholar: sits within and does nothing but real or compose.-P.

Dr. Swift has an odd blunt way, that is mistaken, by strangers, for ill-nature.-CTis so odd that there's no describing it but by faets.- I'll tell you one that just comes into my heal. One evening Gay and I went to see him : you know how intimately we were all aequainted. On our coming in; "Hey-day, gentlemeu," says the Doctor, " what's the meaning of this visit? How come you to leave all the great lords, that you are so fond of, to come hither to see a poor Dean?"-Because we would rather see you than any of them.- " $\mathrm{Ay}$, any one that lid not know you so well as I do, might believe you. But, since you are come, I must get some supper for you, I suppose?" —No. Doctor, we have supped already.- "Supped already! that's impossible: why, "tis not eight o'clock yet."-Indeed we have.-." That's very strange: but if you had not supped, I must have got something for yon.-Let me see, what should I have had? a couple of lobsters? ay, that would have done very well; - - two shillings: tarts; a shilling. But you will drink a glass of wine with me, though you supped so much before your usual time, only to spare my pocket?"-No, we had rather talk with you, than drink with you.-." But if you had supped with me, as in all 
reason you ought to have done, you must have drank with me.-A bottle of wine; two shillings. - Two and two, is four; and one is five: just two and sixpence a piece. There, Pope, there's half-a-crown for you; and there's another for you, sir: for I won't save anything by you I am determined.' 'This was all said and done with his usual seriousness on such occasions; and in spite of everything we could say to the contrary, he actually obliged us to take the money. $-P$.

There is but little that is worth reading in Gower: he wants the spirit of poetry, and the descriptiveness, that are in Claucer. $-P$.

Mr. Sackville (afterwards the first Earl of Dorset of that name) was the best English poet, between Chaucer's and Spenser's time. His tragedy of Gorboduc is written in a much purer style than Shakespeare's was in several of his first plays. Sackville imitates the manner of Seneca's tragedies very closely, and writes without affectation or bombast; the two great sins of our oldest tragic writers. The Induetion in the Mirrour for Magistrates was written by him too, and is very good and very poetical. $-P$.

Golding's Translation of Ovid's Metamorphosis, is a good one considering the time when it was written.* It is in Alexandrine verse, as well as Phaer's Virgil.- $P$.

Michael Drayton was one of the imitators of Spenser: and Fairfax another. Milton, in his first pieces, is an evident follower of Spenser too; in his famous Allegro and Penseroso, and a few other pieces. $-P$.

Webster, Marston, Goff, Kyd, and Massinger, were the

* It was first published in 1567.-Spence. 
persons he instaneed as tolerable writers of tragedy in Ben Jonson's time. $-P$.

Carew (a bad Waller), Waller himself, and Lord Lansdown, are all of one school; as Sir John Suckling, Sir John Mennis, and Pryor, are of another.-P.

Craslaw is a worse sort of Cowley: he was a follower too of Petrarch and Larino, but most of Marino. He and Cowley were good friends; and the latter has a good copy of verses on his death.- $P$.

About this pitch, were Stanley, the author of the Lives of the Philosophers; Randolph, though rather superior; and Sylvester, though rather of a lower form. $-P$.

Cartwright and Bishop Corbet are of this mediocre class of poets; and Bagnel, the author of the Counter Scuffle, might be admitted among them.- $P$.

Samuel Daniel the historian, is unpoetieal ; but has good sense often.- $P$.

Herbert is lower than Crashaw, Sir John Beaumont higher, and Đonne, a good deal so.- $P$.

Politian is one of the first rate modern Latin poets. Molza, very good.-Bembo, and Sadoleto, write pure Latin: but are stiff and umpoetical.- $P$.

Voiture, in his letters, wants sentiment: he wrote only to divert parties orer their tea.- $P$.

Marot D'Aceilly, Habert, De C'erisis, and La Fontaine, are all of a school. $-P$.

Chapelain is about the rate of our Sir W. Davenant : he las strong thoughts and no versification. $-P$.

Mr. Pope learned to draw of Jervas for a year and a half. (With what pleasure he stole some strokes, in 
Tilleman's absence, in the landseape he was drawing at Lord Radnor's.) "Which gives you the most pleasure, sir, poetry or painting?"-_ I really can't well say ; both of them are extremely pleasing." $-P$.

Among the imitations in Pope and Swift's Miscellanies, that of the City Shower was designed by Swift to imitate Virgil's Georgie style. The Alley, in imitation of Spenser, was written by Mr. Pope, with a line or two of Mr. Gay's in it: and the imitation of Chancer was wholly by Mr. Pope.- $P$.

That notion of Sir William Davenant being more than a poetical child only of Shakespeare, was eommon in town; and Sir William himself seemed fond of having it taken for truth. $-P$.

There are three distinct tours in poetry; the design, the language, and the versifieation. (To which he afterwards seemed to add, a fourth, the expression; or manner of painting the humours, elaracters, and things that fall within your design.) $-P$.

After writing a poem, one should correet it all over, with one single view at a time. Thus for language; if an elegy; " these lines are very good, but are not they of too heroical a strain?" and so vice versa. It appears very plainly, from comparing parallel passages touched both in the Iliad and Odyssey, that Homer did this; and it is yet plainer that Virgil did so, from the distinet styles he uses in his three sorts of poems. It always answers in him; and so constant an effect could not be the effeet of chanee. $-P$.

In versification there is a sensible difference between 
softness and sweetness* that I could distinguish from is boy. Thus on the same points. Dryden will be found to be softer, and Waller sweeter. It is the same with Orid and Virgil; and Virgil's Eclogues, in particular, are the sweetest poems in the world.- $P$.

What the Romans called rotunelitas versuem, (for 1 know no English word for it,) is to be met with remarkably in Waller too; and particularly in his naval eopy of verses. $-P$.

I wrote things-I'm ashamed to say how soon.-Part of an Epic Poem $\dagger$ when about twelve. The scene of it lay at Rhodes, and some of the neighbouring islands; and the poem opened under water with a description of the Court of Neptume. That eouplet, on the cireulation of the blood, in the Dunciad, was originally in this poem, word for word, as it is now. $+-P$.

I was aequainted with Betterton from a boy.-P.

Wyeherley was Mr. Pope's first poet-friend, and Walsh his next.-Mamick.

Mr. Pope was but a little while under his master at T'wiford. He wrote extremely young; and among other things a satire on that gentleman for some faults he had discoverel in him.-LI/.

He set to learning Latin and Greek by himself, about twelve; and when he was about fifteen he resolved that he

+ To Mr. Blacklock, the sweetness of verses seemed to depend upon a proper management of the pauses; softness, on a proper intermixture of the vowels and consonants. - Note by Mr. Spence.

+ Deucalion was the hero of it.-MS. $B$.

\$ As man's meanders to the vital spring

Roll all their tides, then back their circles bring.

Dunciad, b. iii. v. 56. 
would go up to London and learn French and Italian. We in the family looked upon it as a wildish sort of resolution ;* for as his health would not let him travel, we could not see any reason for it. He stuck to it: went thither; and mastered both those languages with a surprising dispatch. Almost everything of this kind was of his own acquiring. He had had masters indeed, but they were very indifferent ones; and what he got was almost wholly owing to his own unassisted industry.- $M$.

Ile was a child of a particularly sweet temper, and liad a great deal of sweetness in his look, when he was a boy.- $M$.

This is very evident in the picture drawn for him when about ten years old: in which his face is round, plump, pretty, and of a fiesh complexion.-I have often heard Mrs. Pope say, that he was then exactly like that picture. -I have often been told that it was the perpetual application he fell into, about two years afterwards, that changed lis form and mined his constitution.-The laurel branch in that picture was not inserted originally ; but was added, long after, by Jervas.- $M$.

Monsieur Fenelon (the author of Telemachus, and Archbishop of (ambray) used to entertain Protestants as readily as Papists. He was above the little distinctions of country or religion, and used to say, " that he loved his family better than himself; his country better than his family; and mankind better than his country; for I am more a

* Note by Mr. Spence from first MS. copy.-What his sister, Mrs. Racket, said- "For you know, to speak plain with you, my brother has a maddish way with him." Little people mistook the excess of his genius for madness. "Igad that young fellow will either be a madman or make a very great poet."-Rag Smith ajter being in Mr. Pope's company when ubout fourteen. 
Frenchman, (added he,) than a Fenelon ; and more a man than a Frenchman."-The Chevelier Rumsety, * anthor of the Travels of Cyrus.

The true reason of the arehbishop's being banished from the eourt, was the honesty he showed in not advising I wonis the Fourteenth to own his marriage with Madame de Maintenon.—. It is eertain then that they were married ?" —. Oh, unquestionably, sir.-The king had asked Bossuet, Bishop of Meaux, his opinion in that aftair; who spoke mueh in praise of the lady, and alvised what he saw would best please the king: but alded, that if his majesty had the opinion of the Arehbishop of Cambray on his side, it wonld be of mueh more weight and use than any one's else. On this the king eonsulted the arehbishop; who (as his enemy hal forescen) was not eourtier enongh to say anything to encourage sueh a declaration; and on the contrary gave some hints of the prejudiee it might be of to his majesty's affairs, in their then situation. This soured the king so much against him, as he expeeted it would: and after Marlame de Maintenon and her ereatures, insinuated it into the king, that Monsieur Fenelon had had the insolenee of designing to represent his majesty under the character of Idomeneus in his Telemaehus; and both him and the lady (in part) under those of Pigmalion and $\Lambda$ starbé : and this finished his disgrace." $-R$.

The Duke of Burgundy eontinued still fond of him ; and mindful of the preeepts he had given him. "They have taken away my Telemachus from me," said the prince, " but 'tis no matter, here I have it, and it shall ever remain in my heart."- $R$.

- Ramsay was several years secretary to Fenelun. 
The arehbishop asked Mr. Ramsay once, "What the English said of Locke." Ramsay told him that his acquaintance from England commended Locke extremely for a clear head and a fine way of reasoning; they said he saw the surfaces of a vast number of things very plainly; but that he did not pierce deep into any of them: "In short, my lord," says Ramsay, "I take hin, by their account, to be pretty much like the Bishop of Meaux." The archbishop stopped him short; told him that he was not sufficiently acquainted with the talents of the Bishop of Meaux; and then run out into a panegyric of that prelate, in all the particulars where his character would bear it. It was thus that he revenged himself on his enemies. $-R$.

There was a spy sent into the Archbishop of Cambray's family, by the contrivance of his most capital enemies. The man lived there as a domestic, for three years; and though so great a villain, was at length so far moved and converted by that great man's behaviour, that he one day begged to be admitted into his apartment; fell down on his knees, and confessed the whole affair. The archbishop forgave him; thanked him for the discovery, and only bid him take care of those that sent him ; for they might do lim some mischief, for being honest at last.- $R$.

When Louis the Fourteenth found that all his persecutions of the Protestants were ineffectual, as to the recovering any number of them to the church, he sent for the archbishop (who had always thought persecution for religion impolitic, as well as unchristian), complained to him of the obstinacy of those heretics; and said he would have him go down and try whether he could convert them with his preaching. " That I will with all my heart, sire," replied 
the arehbishop, " if you will be so good as to call off your dragoons; for 'tis they that drive then so much farther from 11s." $-R$.

The archbishop, when most in favour, used to say ; "I would rather see the king lose half his dominions, than oceasion one unnecessary battle, in which the lives of so many eitizens were to be thrown away."

['The archhishop's diocese lay part in the German, part in the French dominions. At the same time that he was entirely ravaged by the French soldiers, the Duke of Marlborough and the confederate army spared everything that belonged to him on their side of the country. The Duke of Marlborough had a vast esteem for his character: he wrote several letters to him: and in one of them in particular he tells him that " if he was sorry he had not taken Cambray, it was not for the honour of such a conquest, so much as to have had the pleasure of seeing so great a man." $-R . *$ ]

The archbishop used to rise by four in the morning; think for about two hours; and then write. His time was chiefly spent in study, performing the duties of his function, and amusements of eharity. As for the latter, it was very usual with him whenever he went into the country to take the air, to eall at the houses of poor people, where he would eat and driuk, and enter into familiar conversation with them. He would inquire how they lived, and what family they had; advised with them what they should do with such and such a child: and often would apprentice out their sons, or give portions with their daughters. It is inconceivable with what pleasure the people expected him

- Addition from MS. $B$. 
where he used to pay these little visits; or how much they regarded him wherever he passed. They all loved him, and looked upon him as their common father.- $R$.

" He had all that was good in his heart, and all that was fine in his head; and never made use of the latter but to advance the former." * This character was given of the archbishop by a very sensible Swiss; and no one ever deserved so high a character better.- $-R$.

Lord Peterborough, after a visit to the archbishop, said, "He was cast in a particular mould, that was never" used for anybody else: he is a delicious creature! but I was forced to get away from him as soon as I possibly could; for else he would have made me pious." $-R$.

Cardinal Alberoni used to say of Telemachus, " that it was a well written book; but a' very dangerous one for princes to read." $-R$.

The archbishop was void of all formality, and full of the truest politeness; that of making everybody easy about him.-One day there were two German noblemen at his table, who, when they were to drink to the archbishop, to show their respect to him, rose out of their seats; and stood all the while they were drinking to him, according to the custom of their own country. Some young French

* I find this character given to Fenelon by the Abbé de Mon. ville in his preface to the Life of Mignard, printed at Paris in 1730. "M. de Fenelon étoit un beau genie, les sentimens de son ame et les graces de son imagination lui ont donné un stile unique, qui charme, qui enchante; il avoit le beau dans l'esprit, le bon dans le cour ; et ne montroit jamaic l'un, que pour faire aimer l'autre."At the end of this book are two dialogues on painting by Fenelon, well worthy the attention of the reader of taste; they were printed in a separate form by the present writer a few years since for the gratification of a few friends.-Editor. 
officers, who were at the table at the same time, eould searcely contain themselves from bursting out into a laugh at such a novelty. The archbishop gave them a gentle reprimand by his look; called for wine; and stood up and drank to the Germans in the same manner that they hat done to him. The offieers afterwards owned, how mucle they were ashamed of themselves; and that they immediately felt, how greatly the arehlishop's humanity was preferable to that eustomary sort of politeness, of which alone they had had any idea until that time.- $R$.

In one of the Duke of Marlborough's eampaigus in Flanters, when the French forces were a good deal distressed, the arehbishop opened his granaries at Cambray for their use. This was in the height of his disgrace, and ill usage from the court. When the king heard of it, he sighed and said: " he could expeet no less from his generous soul." The king ordered him to be reimburset, but he never was. $-R$.

[Ramsay has a noble collection of M. Fenelon's from the ancients on the ro raróv.-." The arehbishop does not teach that the love of God ought to be the sole motive?". No, sir; only the prineipal."-Ramsay.-The use of the other motives and sanetions may be to bring us to this. -Hooke. (His distinction between gingerbreal loue, and mathematic love.) - " But after all there is not one in a thousand can aet by this motive?"- - R.-." True, sir ; but those that can will aet best: you ean't reach the moon if you aim at her ; but yet will shoot higher than if you aimed at a bush." - II.--The great point is to get rid of self ; and to look upon ourselves as chirfly concerned in the interest of the whole.-R.-They were mighty angry with Fenelon 
because he was of opinion that we should not love God as we love our horses and our w-s.*-R.]

Doctor Clarke has but one error in relation to the Trinity; his maintaining the free-production of the Son. I am very well acquainted with him; and think him the finest reasoner I ever met with. $\mathrm{He}$ has a transparency of mind peculiar to himself. I don't know whether I make nyyself understood: but what I mean is, that he does not only see things clearly himself, but makes you see clearly whatever he is speaking of.- $R$.

Ramsay had then gone a good way in an Answer to Spinosa; a Treatise on the Progress of Human Understanding: and another high philosophical work; in which there were several notions, that would have made him be looked upon as an Heretic in our church, as well as his own.- His favourite point seemed to be that, of all things being good at first; that there has been a great degeneracy and disorder in the world; and that there will be a general restoration. " The whole," says he, " depends on these two principles; that God would not create anything bad; and if it became bad would not suffer it to continue so for ever." $+-R .-[$ What one of his friends (Mr. H.) said of his most elevated notions, seemed to be very well grounded: " that they were like stars when of too great a height, that neither give us warmth nor light." - Spence.]

I should have been very glad to have seen the proofs of what (he said) he had fully made out, in his Progress of

* Addition from MS. B.

$\uparrow$ Ramsay says there are three distinct Divine Agents mentioned in Scripture : he does not stick at calling them three beings, but

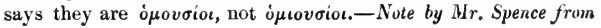
is. $B$. 
the Understanding: " that all theologieal knowledge was nobler and better preserved among the Chaldeans than among the Egyptians; that the latter clouled it much by their hieroglyphies; that it grew still more elonded and depraved among the Greeks: and received its last and worst corruption among the Romans." If this was well made out, it might be of good service to show the necessity and propriety of the time in which our Saviour came into the world to instruet mankind.*-Spenee.

There is the same difference between Corneille and Racine, as there is between un homme de gémie and un homme d'esprit. Corneille has more fire than Racine, bolder strokes, and in some things is not unlike our Shakespeare. Racine's tragedies are all good; and as to Corneille's, even his greatest enemies would allow six of his to be so.-Ramsay.

The arehbishop of Cambray used to say, that Racine's Athalie was the most complete piece he ever read; and that in his opinion there was nothing among the ancients, not even in Sophocles, equal to it. $-R$.

Since the translation of Paradise Lost into French, Milton begins to be greatly admired at Paris, even the Cardinal Polignac used to think, that most of the high things we said of him were overstrained and out of partiality. The cardinal was convinced at once, on an English gentleman's sending him only the contents of each book

* All the deities of the Greeks are to be reduced to three; and those three signify the power, wisdom, and goodness of the one great Being. - Venus was heavenly love, she was called Urania : the Greeks made a terrestrial Venus of the froth of the sea : and the same happened in many other cases. - Note by Mr. Spence frum MS. B. 
translated into French. "The man," said he, "who could contrive such a plan, must be one of the greatest poets that ever was born." $-R$.

Ramsay's Cyrus was translated by Mr. Hooke in twenty days. Mr. Hooke was then at Bath for his health; and Dr. Cheyne's brother was so good as to write for him. Hooke walked about the ehamber and dietated to him ; so that it was a sort of exereise as well as study. He always took the first expressions; and if a passage did not fall readily into English to his mind, he marked the plaee; and went on to the next passage, to keep up his warmth and freedom. Might not this be one reason of its being so generally mistaken for an original for a good while after it was published? Almost everybody then, and many still imagine, that Ramsay himself had written it in English, as well as in French.* $* R$

Bianchini lad made several steps toward diseovering the parallax of the stars, many years before Cassini began upon it. He was making those observations no less than twelve years from modern buildings, before he found that they were not fit for points of sueh nieety and exaetness. He then followed them for fifteen years more, from the top of one of the old Roman buildings ; and had earried them on with as mueh aceuraey as possible, when Cassini offered his diseoveries to the publie. What hindred Bianchini from publishing was (as he said), the restraint of the eountry: and indeed nobody, yet in Rome, dares assert roundly that the earth moves and not the sun.- $R$.

The Freneh philosophers at present ehiefly follow Male-

* Hooke corrected and altered many things in translating by Ramsay's allowance. It was translated from the MS. copy.Nute by Mr. Spence from his pupers. 
branche. They admire Sir Isac Newton very mueh, but don't yet allow of his great prineiple: it is his particular reasonings, experiments, and penetration, for which they so mueh admire him.- $k$.

Lesky, after all the pains he had taken to cenvert the Chevalier de St. George, thought latterly that he might very well have spared himself so mueh trouble.-IIe said, a little before he died, that it was searce worth while to make a eonvert from either of the religions to the other. $-R$.

They are strangely distracted (in Franee) between the Jansenists and Molinists. Soon after I eame into the Archbishop of C'ambray's family, I asserted, at his table, that IIomer was a Molinist ; everyboly stared at the assertion : but after, when I referred them to the remarkable speech of . Inpiter in the beginning of the Odyssey, they allowed I had reason for what I said.- $R$. [Adelition from MS. B.]

('ardinal Fleury says of the young king. (Louis XV.) that, " he has nothing shining; but that he has mighty good solid sense, and judges very well of things." In short, he can make the ehild do anything he has a mind to. $-R$.

The king ordered one of his attentants to give the black boy (who brought up the noblemen's hats) a livre: the gentlemm said so as to be heard by the king; " this Louis d'or the king gives you, and I this livre."-R. [Addition fiom LS. B.]

The queen is an extreme good woman. She very little regards pomp ; and gives away most of her moterate allowanee (about tive hundred pounds a month, for what we eall fin money,) in eharities. The king does not much care for her, but the cardinal often makes him say kind things. to ber. $-R$. 
When the king was a ehild, he showed a good deal of cruelty in his disposition; he delighted ehiefly in tormenting the animals he had to play with; he would eripple one, and put out the eyes of another. This much alarmed some people; at first, they were very apprehensive that he might be as barbarous to men, as he was to his birds, when he should come to have them as much in his power as his playthings. However it seems pretty well off at present; and it may perhaps have been a very prudent thing that they gave him sueh a turn to hunting: for that may possibly have diverted those passions to that fashionable perseeution of animals, whieh might else have fallen upon his subjeets. $-R$.

What sort of man is the present pope? (Benediet XIII.) - He is a good weak man, who delights in the trifles of religion; and has no notion at all of the true spirit of it. $-R$.

Not one of the Jesuits who have been turned out of their schools or houses, was ever known to write or speak anything whieh might disgrace their order. $-R$.

Why was the Freneh chureh so very angry with Father Courayer, for so charitable a work as writing on the validity of our Ordinations?-Because they re-ordain any English ecelesiastie that eomes over to them; and consequently, to allow his doetrine, would be to give up the greatest point of all, the infallibility of the chureh.- $R$.

When the eelebrated Father Bourdelot (who has sometimes been ealled the French Tillotson) was to preach onee on a Good-Friday, and the proper officer eame to attend him to chureh; his servants said that he was in his study, and that if he pleased he might go up to him. In going 
up stairs he heard the sound of a violin; and as the door stood a little a-jar, he saw Bourdelot stripped into his cassock, playing a good brisk tme, and dancing to it about his study. IIe was extremely concerned, for he esteemed that great man highly, and thought he must be run distracted. However at last he ventured to rap gently at the door. 'The father immediately laid down his violin, hurried on his gown, came to him (and with his usual composed and pleasing look), said ; "Oh, sir, is it you? I hope I have not made you stay; I am quite ready to attend you." 'The poor man, as they were going down, eould not help mentioning his surprise at what he hat heard and seen. Bourdelot smiled, and said: "Indeed you might well be a little surprised, if you don't know anything of my way on these oceasions; but the whole of the matter was this: in thinking over the subjeet of the day, I found my spirits too much depressed to speak as I ought to do ; so had recourse to my usual method of music and a little motion. It has had its effect, I am quite in a proper temper; and go now with pleasure, to what I should else have gone to in pain." $-R$.

Each of the four columns that support the dome of St. Peter's at Rome, takes up as much ground as a little chapel and convent,* in which one of the architects employed in that work lived; and yet they lo not appear big to the eye, because everything is great about them.-They were designed by Miehacl Angelo, and he insisted earnestly that nothing should be adkled or altered in his design. Bernini afterwards undertook to make a staircase within each of these columns; just as they had hollowed and prepared the inside of one of them,* the whole building gave a crash ;

* St. Silvester's by the Quatre Fontane. 
(and the Italian tradition says it was as loud as thunder.) They put up the stairs in that, but would not attempt any more of them.- $R$.

Mareschal Turenne was not only one of the greatest generals, but one of the best-natured men too, that ever was in the world.-Among several other little domestic examples he gave the following. 'The general used to have a new pair of stockings every week; his gentleman, whose fee the old ones were, had taken them away in the evening, and had forgot to put any new ones in their place. The next morning the Marshal was to ride out to reconnoitre the enemy, and rose earlier than usual. The servant whose business it was to dress him, was in a great deal of confusion at not finding any stockings. "It's very odd," says the Marshal, " that I should be allowed no stockings; but 'tis very lucky that I am obliged to ride out! Here, give me my boots, they'll do as well, nobody will see whether I have any on or not." $-R$.

[There is scarce a genteel family at Avignon but has the pictures of Petrarch and Lamra in their houses. A lady of that country, who piques herself much on being descended from Laura, took it very ill of Mir. R. that he should say, " Petrarch's love for Laura was only Platonic." Ramsay was obliged to recant the heresy; and write a fable against Platonie Love.- $R$.

The (ontward) Rabbi Mr. F. met with in Italy. - What do you think of Moses? - He was a great juggler.-What of Mahomet:' Un scelerato.-What of Spinosa? Un scele-

* There was originally a well for a staircase, and Bernini only put up the stairs in it.-Mr. L. from one of the workmen at St. Peter's in 1751 . 
ratissimo.-What of Jesus? Un grande philosopho.(Jews in Italy not punished for speaking against Jesus, but pmishable for speaking against Moses.) $-R$.

Father Kireher's dissertation on one of the Egyptian obelisks, though there is searce anything certain in it, is one of the greatest efforts of human imagination.*-R.]

“Saerez-vous vos Rois?"-_. Si nous les sacrons, Monsieur! parbleu, nous les massaerons"-was the answer of Lord Peterborough to the Prince of Celamar.- $R$.

Shadwell's Squire of Alsatia took exceedingly at first, as an oecasional play: it discovered the cant terms that were before not generally known, except to the cheats themselves; and was a good deal instrumental in causing that nest of villains to be regulated by public authority. The story it was built on was a true faet.-1Mr. Dennis the Critic.

Otway had an intimate friend (one Blackstone), who was shot; the murderer fled toward Dover; and Otway pursued him. In his return, he drank water when violently heated, and so got a fever, which was the death of him.-Dennis.

Wyeherley was in a bookseller's shop at Bath, or Tumbridge, when Lady Drogheda came in and happened to inquire for the Plain Dealer. A friend of Wycherley's, who stood by him, pushed him toward her, and said, " There's the Plain Dealer, Madam, if you want him ?" Wycherley made his exeuses; and Lady Drogheda said, " that she loved plain-dealing best." He afterwards visited that lady, and in some time after married her. This proved a great blow to his fortunes; just before the time of his courtship, he was designed for governor to the late Duke of Richmond; and was to have been allowed fifteen hundred pounds a year

- The three preceding articles are from MS. B. 
from the government. His absence from court in the progress of this amour, and his being yet more absent after his marriage, (for Lady Drogheda was very jealous of him,) disgusted his friends there so mueh, that he lost all his interest with them. His lady died; he got but little by her: and his misfortunes were such, that he was thrown into the Fleet, and lay there seven years. It was then that Colonel Brett got his Plain Dealer to be acted; and contrived to get the king (James the Second) to be there. The colonel attended him thither. The king was mightily pleased with the play, asked who was the author of it; and upon hearing it was one of Wycherley's, complained that he had not seen him for so many years; and inquired what was become of him. The colonel improved this opportunity so well, that the king gave orders his debts should be discharged out of the privy purse. Wycherley was so weak as to give an account only of five hundred pounds: and so was confined almost half a year; till his father was at last prevailed on to pay the rest, between two and three hundred pounds more.-D.

[Dryden was generally an extreme sober man. For the last ten years of his life he was much acquainted with Addison, and drank with him more than he ever used to do ; probably so far as to hasten his end. $\left.-D .{ }^{*}\right]$

Even Dryden was very suspicious of Rivals. He would eompliment Crown, when a play of his failed, but was cold to him if he met with success.-He used sometimes to own that Crown had some genius; but then added, " that his father and Crown's mother were very well aequainted." Old Jacob Tonson.

None of our writers have a freer easier way for comedy * Addition from MS. B. 
than Etherege and Vanlurugh._- Now we have named all the best of them," (after mentioning those two, Wyeherley, Congreve, Fleteher, Jonson, and Shakespeare.) - Wr: Pope.

" Ay. Mr. Tonson, he was ultimus Romunorum;" (with a sigh.) Speaking of poor Mr. Congreve, who died a year or two before.- $P$.

Garth, Vaubrugh, and Congreve, were the three most honest hearted, real good men, of the poetical members of the kit-eat elub.-Pope and Tonson.

Addison wrote the four first acts of his Cato abroad;* at least, they were written, when I met him, accidentally on his return, at Rotterdam.-Tonson.

The love-part (in Cato) was flung in after, to comply with the popular taste; and the last act was not written till six or seven years after, when he eame home.-Pope.

An andience was laid for the Distressed Nother; and when they found it would do, it was praetised again, yet more suceessfully for Cato._Lord Bolingbroke's earrying his friends to the house, and presenting Booth with a purse of guineas, for so well representing the character of a person " who rather chose to die than see a general for life;" was an aceidental piece of good luck, and what earried the success of the play much beyond what they ever expeeted.-P.

Addison was very kind to me at first, but my bitter enemy afterwards. $-P$. [Addition from IIS. B.]

He translated the first book of the Iliad that appeared as Tickel's; and Steele has blurted it out in his angry preface against Tickel. $\downarrow-P$.

* Note by Mr. Spence.-He wrote them all five at Oxford, and sent them from thence to Dryden: to my knowledge.-Dr. Young.

+ It was in a dedication to Congreve, prefixed to an edition of 
Addison was so eager to be the first name, that he and his friend Sir Richard Steele used to run down even Dryden's character as far as they could. Pope and Congreve used to support it.-Tonson.

The worst step Addison ever took, was his accepting the secretary's place. He did it to oblige the Countess of Warwick, and to qualify himself to be owned for her husband. $-P$.

He had thoughts of getting that lady from his first being recommended into the family.-Tonson.

Mr. Pope's poem grows on his hands. The first four or five epistles will be on the general principles, or of "The Nature of Man ;" and the rest will be on moderation, or "'The Use of Things." In the latter part each class may take up three epistles: one, for instance, against Avarice; another against Prodigality; and the third, on the moderate use of Riches; and so of the rest.-These two lines contain the main design that runs through the whole:

" Laugh where we must; be candid where we can;

But vindicate the ways of God to man."-POPE.

Pryor kept everything by him, even to all his school exereises. There is a manuscript collection of this kind in his servant Drift's hands, which contains at least half as nuch as all his published works. And there are nine or ten copies of verses among them, which I thonght much better than several things he himself published. In particular, I remember there was a dialogue of about two hun"The Drummer, or Haunted House;" but I have been unable to procure it.-Mr. Nichols, in a note to his Collection of Poems, vol. iv. says, that Mr. Watts, the printer, told a friend of his, "that the Translation of the First Book of the Iliad was in Tickel's hand writing, but much corrected and interlined by Addison."-Editor. 
dred rerses, between $A$ pollo and Daphne, which pleased me as much as anything of his $\mathrm{I}$ ever read. $-P$.

There are, also, four dialogues in prose, between persons of eharaeters very strongly opposed to one another, which I thought very good. One of them was between Charles the Fifth and his tutor, Adrian the Sixth; to show the different turns of a person who had studied human nature only in his eloset, and of one who had rambled all over Europe. Another between Montaigne and Lucke, on a most regular and a very loose way of thinking. A third, between Oliver Cromwell and his mad Porter: and the fourth, between Sir Thomas More and the Viear of Bray. $-P$.

Prior left most of his effeets to the poor woman he kept company with, his Chloé ; everybody knows what a wretch she was. I think she had been a little alehouse-keeper's wife.*-P.

Mr. Adlison wrote very fluently: but he was sometimes very slow and scrupulous in correcting. He would show his verses to several friends; and would alter almost everything that any of them hinted at as wrong. $\backslash$ He seemed to be too diffident of himself; and too much eoneerned about his charaeter as a poet: or (as he worded it) too solieitous for that kind of praise, which, God knows, is but a very little matter after all :- " I wonder then why his letter to Sacheverel was published?"-That was not published till after his death, and I dare say he would not have suffered it to have been printed had he been living; for he himself used to speak of it as a poor thing. He wrote it when he was very young; and as such, gave the eharacters of some of our best poets in it, only by hearsay. Thus his eharacter

- This celebrated lady is now married to a cobbler at 
of Chaucer is diametrically opposite to the truth; he blames him for want of humour. The character he gives of Spenser is false too; and I have heard him say, that he never read Spenser till fifteen years after he wrote it. $-P$.

Many of his Spectators he wrote very fast; and sent them to the press as soon as they were written. It seems to have been best for him not to have had too much time to correct. $-P$.

Addison was perfect good company with intimates; and had something more charming in his conversation than I ever knew in any other mau: but with any mixture of strangers, and sometimes only with one, he seemed to preserve his dignity much; with a stiff sort of silence.- $P$.

Lord Dorset used to say of a very good-natured dull fellow, "'Tis a thousand pities that man is not ill-natured ! that one might kick him out of company." $-P$.

When Clement the Eleventh had declared in one of his decrees, " that any one who held that grace might not be had out of the pale of the church, should be accursed;" one of the cardinals who was complimenting his holiness on that head, said, he could have wished it had run thus; " whoever holds that persons out of the chureh eannot be saved, let him be accursed." The pope answered, "that would have been better, had it been time for it yet; and that it night be hoped to come to that, about a humdred years hence."-Ramsay.

It was a common saying with the Arehbishop of Cambray, "We Catholics go too slow, and our brothers the Protestants go too fast." $-R$.

Ramsay was but a little above twenty, when he first went to the Archbishop of Cambray's. That good prelate gave 
him the liberty of his library; and favoured him with instructions in his studies. He had, in partieular, the use of all the fathers, in which the most material passages were marked out by the arehbishop in his own hand, and found those particular direetions of very great use to him.- $R$.

The arehbishop gave him this for his great rule, in studying their religion; "ever to distinguish what doetrines and conclusions are bottomed on councils, and what on the schoolmen only, or their interpreters. The latter, said he, we have nothing to do with." $-R$.

The Abbé des Fontaines endeavoured as much as he could to irritate the Princess de Conti against Ramsay. "I had a little before been obliget to decline the offer of being governor to one of her sons: that had given some disgust; and the abbé heightened it, by insinuating that a known amour between that princess and the Count of Genoa, was disguised under the story of Striangeus and Zarina." That Count proposed their joining to write a criticism of Cyrus; the princess, half in jest and half in earnest, complied with the proposal. It was she who formed the plan, and wrote the dedication; and the count and the abbe wrote the rest. The countess is one of the most polite and learned ladies in Europe, she reads Horace and Homer in a masterly manner, and has a hundred other exeellencics. After all, the eharacter of Zarina does not agree with that of the princess, in the main article; for Zarina refuses the last favour to her gallant: and indeed the whole story was so far from being invented to represent that princess, or any other lady living; that'tis an old one, and borrowed from one of the later Roman historians. $-R$.

["Arehbishop Tillotson's Sermon against Transubstan- 
tiation, would convince me of the truth of transubstantiation."-Hooke.-How differently do we judge of things when we come to them strongly prepossessed by party! I thought it was one of the finest things that could be written against it: and perhaps both of us are in the wrong. $-R$.

Lord Bolingbroke is one of the politest as well as greatest men in the world.-He appeared careless in his talk of religion.-In this he differed from Fenelon : Lord Bolingbroke outshines you, but then holds himself in, and reflects some of his own light, so as to make you appear the less inferior to him.-The archbishop never outshone; but would lead you into truths in such a manner, that you thought you discovered them yourself.* $-R$.]

Sir Isaac Newton does not look on attraction as a cause, but as an effect; and probably as an effect of the ethereal fluid. The ancients had a notion much of the same kind, which I have some thoughts of proving in a memorial to the Academy of Sciences at Paris, in order to incline those gentlemen to come into that truth of Sir Isaac's ; and not only to allow him (which they already do) to be the greatest geometrician that ever was. $-R$.

Sir Isaac Newton, a little before he died, said : “I don't know what I may seem to the world, but, as to myself, I seem to have been only like a boy playing on the sea shore, and diverting myself in now and then finding a smoother pebble or a prettier shell than ordinary, whilst the great ocean of truth lay all undiscovered before me." $\uparrow-R$.

* Additions from MS. B.

† This interesting anecdote of our great philosopher's modest opinion of himself and his discoveries, is only another proof of his consummate wisdom. It will recall to the memory of the poetical 
reader the following beautiful passage from the Paradise Regained of our great poet.

Who reads

Incessantly, and to his reading brings not

A spirit and judgment equal or superior,

(And what he brings, what need he elsewhere seek)

Uneertain and unsettled still remains;

Jeep vers'd in books, and shallow in himself,

Crude or intoxicate, collecting toys,

And trifles for choice matters, worth a sponge,

$\Lambda$ s ehildren gathering pebbles on the shore.

EDITOR.

END OF SECTION $\mathrm{r}$. 


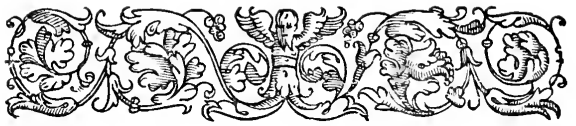

\section{SPENCE'S ANECDOTES.}

\section{SECTION II. 1730-32.}

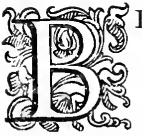

IANCHINI endeavoured to find out the parallax of the fixed stars from the place of the earth in its annual orbit, at each solstice. Dr. Halley's medium for discovering the same, is the moon. Ile has been making his observations from that planet thirteen years already, and says it will require seven more. He is fully persuaded that it may be discovered that way.-Ramsay.

Cavalier was the first who stirred up the Cevennois. His own imagination was inflamed; and he took advantage of the constitution of his countrymen, who are very subject to epileptic disorders. The agitations, which their fits gave them, were looked on as the effects of inspiration; and so were made of great service toward carrying on a religious war. They defended themselves long, and in a surprising manner, against the king's armies. On their dispersion, at last, many of them got over into England. Their fits continued when they were here; and on the return of them would give involuntary motions to their bodies and shakings to their limbs. These were what were then ealled the 
French prophets. The great aim of their doctrines was the near approach of the millenary state. Everything was to be altered, the hierarehy destroyed, and an universial theoeraey to obtain on earth. I was then at Lomdon, learning the mathematics, under Fatio ; and, by his desire, went two or three times with him to hear them. Ile thonglit all their agitations the effect of a heavenly inspiration ; and actually eaught them of them himself.-When that gentleman was speaking, one day, of the eause of attraction, he said, (with a contidence umusual to him,) that he hat absolutely discovered it ; that it was the ethereal fluid: " and where," added he very gravely, "do you think I discovered it? I was yesterday at a meeting of the prophets, and whilst I was lost in thought, it struck into my mind, like a sudden gleam of light, all at once."--Iowever this happened, it is the very thing which Sir Isaae Newton has since shown. Sir Isaac himself had a strong inclination to go and hear these prophets, and was restrained from it, with difficulty, by some of his friends, who feared he might be infected by them as Fatio had been.- $R$.

The Abbé Fleury's Eeelesiastical Ifistory is allowed, on all sides, to be the best that ever was written, though it is put into the Index Expurgatorius.-R.

Cardinal Alberoni has the greatest art imaginable of seeing into the hearts and designs of men; but when he is a little heated, he lays himself too open to others: was he as impenetrable, as he is penetrating, he would be one of the completest politicians that ever was. $-R$.

The Arehbishop of Cambray often said, that " of all the Protestant Churehes, the Chureh of England alone could do anything in disputing with the Catholies: the Calvin- 
ists," says he, " have made themselves harmless enemies, by holding their fatality ; and the Lutherans have disarmed themselves of one of their chief weapons, by their doctrine of consubstantiation." $-R$.

Pope's character of Addison is one of the truest, as well as one of the best things he ever wrote: Addison deserved that character the most of any man.- - Yet how eharming are his prose writings! He was as much a master of humour, as he was an indifferent poet.-Dr. Lockier,* Dean of Peterborough.

* The Dean is about sixty-four years old. He travelled with Sir Paul Rycaut, and was chaplain and secretary to Lord Molesworth, whilst that lord was aide-de-camp to the Duke of Marlborongh.-Note by Mr. Spence from papers.

"Dr. Lockier in the former part of his life was chaplain to the factory at Hamburgh, from whence he went every year to visit the cuurt of Hanover; whereby he became well known to the king, George the First, who knew how to temper the cares of royalty with the pleasures of private life; and commonly invited six or eight of his friends to pass the evening with him. His majesty seeing Dr. Lockier one day at court, spoke to the Duchess of Ancaster, who was almost always of the party, that she should ask Dr. Lockier to come that evening.-When the company met in the evening, Dr. Lockier was not there; and the king asked the duchess if she had spoken to him, as he desired.- ' Yes,' she said, ' but the doctor presents his humble duty to your majesty, and hopes your majesty will have the goodness to excuse him at present : he is soliciting sıme preferment from your majesty's ministers; and fears it might be some obstacle to him, if it should be known that he had the honour of keeping such good company.' The king langhed very heartily, and said, he believed he was in the right. Not many weeks afterwards, J). Lockier kissed the king's hand for the Deanery of Peterborough; and as he was raising himself from kneeling, the king inclined forwards, and with great good humour whispered in his ear, 'Well, now, doctor, you will not be afraid to come in an evening; I would have you come this evening.'

"Lockier was a man of ingenuity and learning, had seen a great 
I was about seventeen, when I first came up to town, an odd looking boy, with short rough hair, and that sort of awkwardness which one always brings up at first out of the country with one. However, in spite of my bashfuluess

deal of the world, and was a most pleasant and agreeable compan. ion ; was one of Dr. Pearce's (Bishop of Rochester) most intimate friends, and at his death bequeathed to him his library, which was a good one. As Dr. Lockier was himself an excellent story-teller, so had he written in a large quarto book every good story that ever he had heard in company; and this book used to lie in his parlour, for his visitors to turn over and amuse themselves, till he should come to them. It contained a fund of entertainment; and it is a sign that it was conceived so, because some one or other thought it worth while to steal it: it never came to Jr. Pearce's hands, and he often regretted the loss of it."-Bishop Newton's Memoirs of his own Life, p. 48.

Mr. Malone observes that this can hardly be correct, for had the MS. come into Dr. Pearce's hands he must have immediately consigned it to the flames, in conformity to the solemn injunction of Dr. Lockier's will, which adjures his executors to burn all his papers or manuseripts whatsoever as soon as possible after his burial. And therefore Dr. Pearce could not have often regretted the loss of it.

From Mr. Malone's very accurate researches, it appears, that Francis Lockier, son of William Lockier of Norwich, was born 1668 ; and in 1683 became a member of Trinity College, Cam. bridge; he was entered as a sub-sizer, (i.e. a candidate for the first sizership, but the term is not now in use.) - His first conversation with Dryden therefore took place in 1685. In January, 1686-7, he took the degree of Bachelor of Arts, and that of A.M. in 1690. In 1717, when George the First visited Cambridge, he was created Doctor in Divinity; and on the 19th March, 1724-5, was made Dean of Peterborough. He was also rector of Hanworth and Aston.-He probably died in 1740, for in August in that year he was succeeded in the Deanery of Peterborough by Dr. John Thomas. The only known printed work of Lockier's is a sermon preached before the House of Commons on the 30th January, 1725-6.-Editor. 
and appearance, I used, now and then, to thrust myself into Wills's, to have the pleasure of seeing the most celebrated wits of that time, who then resorted thither. The second time that ever I was there, Mr. Dryden was speaking of his own things, as he frequently did, especially of such as had been lately published. "If anything of mine is good," says he, "'tis Mac-Flecno; and I value myself the more upon it, because it is the first piece of ridicule written in Heroics." On hearing this I plucked up my spirit so far as to say in a voice but just loud enough to be heard, that "Mac-Flecno was a very fine poem; but that I had not imagined it to be the first that ever was writ that way." On this, Dryden turned short upon me, as surprised at my interposing; asked me how long I had been a dealer in poetry; and added, with a smile, " Pray, sir, what is it that you did imagine to have been writ so before?"-I named Boileau's Lutrin, and Tassoni's Secchia Rapita; which I had read, and knew Dryden had borrowed some strokes from each._-" 'Tis true," said Dryden, " I had forgot them." - A little after Dryden went out; and in going, spoke to me again, and desired me to come and see him the next day. I was highly delighted with the invitation ; went to see him accordingly : and was well acquainted with him after, as long as he lived.- $-L$.

Dryden allowed the Rehearsal to have a great many good strokes in it; " though so severe," added he, " upon myself; but I can't help saying that Smith and Johnson are two of the coolest, most insignificant fellows, I ever met with on the stage." This, if it was not spoke out of resentment, betrayed great want of judgment; for Smith and Johnson are men of sense, and should certainly say but little to such stuff; only enough to make Bays show on.- $L$. 
Dryden was most touched with " The Ilind and the P'anther Transrersed." I have heard him say ; "for two young fellows, that I have always been very eivil to; to use an old man in misfortunes, in so eruel a manner !"- Ind he wept as he said it. $-L$.

'Three of the charaeters in Tate's seeond part of Alsalom and Achitophel, are of Dryden's writing: and are excellently well writ. That of Julian Johnson, under the name of Ben-Jochanan; Shadwell, with the name of $\mathrm{Og}$; and Settle, with that of Doeg.-LL.

In one of Dryden's plays there was this line, which the aetress endeavoured to speak in as moving and affecting a tone as she could:

" $\mathrm{My}$ wound is great, because it is so small!"

and then she pansed, and looked very much distressed. The Duke of Buckingham, who was in one of the boxes, rose from his seat, and added, in a loud ridienling voice:

" Then 'twould be greater were it none at all!"

which had so strong an effect upon the audience (who before were not very well pleased with the play) that they hissed the poor woman off the stage; would never bear her appearance in the rest of her part: and (as this was the second time only of the play's appearance) made Dryden lose his benefit night. $-L$.

Sir George Etherege was as thorough a fop as ever I saw ; he was exactly his own Sir Fopling Flntter. And yet he designed Dorimant, the genteel rake of wit, for his own picture. $-L$.

Nathaniel Lee was fellow of Trinity College in Cambridge. The Duke of Buckingham (Villiers) brought him 
up to town; where he never did anything for him: and that, I verily believe, was one occasion of his running mad. He was rather before my time; but I saw him in Bedlam. I think he died about the time of the Revolution.- $L$.

That Duke of Buckingham was reckoned the most accomplished man of the age, in riding, dancing, and fencing. When lie came into the presence cliamber, it was impossible for you not to follow him with your eye as he went along, he moved so gracefully.-He got the better of his vast estate; and died between two common girls, at a little alehouse in Yorkshire.-It is incredible what pains he took with one of the actor's, to teach him to speak some passages in Bay's part, in the Rehearsal, right.-The vulgar notion of that play's being hissed off the stage the first night is a mistake. $-L$.

The Rehearsal (one of the best pieces of criticism that ever was), and Butler's inimitable poem of Hudibras, must be quite lost to the readers in a century more, if not soon well commented. Tonson has a good key to the former, but refuses to print it, because he had been so much obliged to Dryden.- $L$.

Shefficld, Duke of Buckingham's famous essay, has certainly been cried up much more than it deserves, though corrected a good deal by Dryden. It was this which set him up for a poet; and he was resolved to keep up that character, if he could, by any means fair or foul. Could anything be more impudent, than his publishing that satire, for writing which Dryden was beat in Rose Alley, (and which was so remarkably known by the name of the Rose Alley Satire, as his own! he made, indeed, a few alterations in it first; but these were only verbal; and generally for the worse. $-L$. 
Lazarillo de Tormes was writ by some Spanish bishops, on their journey to the council of Trent. It is in the best of language. When I was saying onee to a Spaniard, that I wondered how those prelates eould be so perfectly well acquainted with all the cireumstances of begging, and such low life; he said that was not at all strange, for they had most of them been mendieant friars.* $-L$.

For my part, I prefer Corneille to Racine; he has more of our Shakespeare in him. Indeed Racine's are the best crying plays.-Moliere is the only good large writer of comedies among the French.- $L$.

I am surprised that they pretend to set up Ariosto against Tasso still in Italy. A party may go a great way at first; but sure they have had time enough to reeover their senses. - Tasso was exeellent too in his Torrismondo; which is allowed to be one of their best tragedies. And the famous Pastor Fido of Guarini is only an affected imitation of Tasso's Aminta.- $L$.

Sannazaro's Areadia is written in prose interspersed with verses; and might probably have given the hint to our Sir Philip Sidney. - $L$.

There are no good larget dramatic writers among the Italians. What comedies Machiavelli did write are very good.- $L$.

Many of the best Italian poets, in their Latin works, write mere centos. [He mentioned Vida, Fracastorius,

* This remark would tell better, if the circumstance was true. But it is now well known that Lazarillo de Tormes was the youthful production of the Historian, Poet, and Suldier, Hurtado de Mendoza.-Editor.

† Sic. 
and Sannazaro, as their three first; and Pontanus, Bembo, Sadoletus, and the Amalthei, among their secondaries.] $-L$.

Lope de Vega's plays are very good; and many of our first plots are borrowed from him. [He confirmed what Lord Bolingbroke said of the Spanish Crities ; * and mentioned Mariana as one of the best of them.-L.]

[Regnier is a very good poet. The French tongue does very well for satire; at least for the sermoni propiora style, that all satire ought to be written in. Horace's Supper. Boileau's Festin, and Lord Rochester's Feast, all rery good. -Rochester, in his Satire on Man, very much improves on his pattern in Boileau.

Boileau, eridently the best of the French poets. His notes very useful, but show that he was an ill-natured man. So did his crying down Hnet as undermining religion beeause he denied the sublimity of that passage in Moses. + The Dean quite of opinion that it is not otherwise sublime, than from the greatness of the thing spoken of,--creation. He fancies too that the quotation is not just, because of the $\tau t$ in it; and added, as from Pearce's observations, that Longinus, in almost all his quotations, differs from his authors: and therefore may be well supposed to have quoted them memoriter.-This may help to show the vanity of Whiston's designing an edition of the New Testament from the quotations of it in the Fathers..$\left._{+}\right]$

[Dr. Swift lies a-bed till eleven o'clock, and thinks of wit for the Day.- $-L$.

* See Sect I. p. 11.

$+\mathrm{E} \iota \pi \varepsilon \nu \dot{o} \theta \varepsilon o \varsigma \phi \eta \sigma \iota \tau \gamma \varepsilon \nu^{\prime} \varepsilon \theta \omega \phi \omega \varsigma, \kappa \alpha \iota \dot{\varepsilon} \gamma \varepsilon \nu \varepsilon \tau o: \gamma \varepsilon \nu \varepsilon \theta \omega \gamma \eta$,

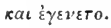

† Additions from papers. 
In the eoffee-honse yesterday I received a letter, in which there was one word which eonsisted of but one syllable, and that syllable of but one letter, and yet the fellow hat contrived to have three false spellings in it.*

If Buchunan's llistory hal been written on a subject far enough back, all the world might have mistaken it for a piece writ in the Angustan age. It is not only his words that are so pure, but his entire manner of writing is as of that age. $-L$.

Settle, in his Anti-Achitophel, was assisted by Matthew Clifford, sprat, and several of the best hands of those times. $-L$.

Considering the manner of writing then in fashion, the purity of Sir John Suckling's style is quite surprising.- $-L$. [He spoke of Farquhar, at the same time, as a mean poet, and as placed by some in a higher rank than he deserved.Mr. Pope always used to eall Farquhar a farce writer.]

Old Salvini of Florence has translated all the Greek poets throughout. His translations are very close, and would serve as excellent comments on several parts of their works. They are written by the side of the originals, on a large margin, and in a very small bal hand, scaree legible to anybody but himself. Had they been fairer, I would have begrged leave to have transeribed some of them; and had them printed in Holland.-L. [The Dean was with Salvini for some time in Lord Molesworth's house in Italy; and explained some of Aidison to him oceasionally.]-MS. B.

Surely the C'hinese are not the wise people they have been eried up for.-It is true they have had astronomy,

- Additions from US, B.-Eye instead of I.-It is not clear whether Swift or Lockier said this.-Editor. 
gunpowder, and printing, for perhaps these two thousand years: but how little have they improved on each of those articles in all that time! When the European missionaries first came among them, all the astronomy they had could not rise to the making of an almanack. Then their printing, to this day, is not by detached letters, but by whole blocks of wood for each page, so that the pieces for a moderate sized book, nust be laid by for a future edition, and would almost lumber up a whole room. Their engineers are sad fellows: indeed they were always for encouraging a spirit of peace; and are some of the worst soldiers in the world. Though they had two hundred and fifty thousand men to defend their famous wall, the Tartars forced their way in through them with blood, and conquered their whole country; and their kings have ever since been of the Tartar race. $-L$.

The great men and celebrated philosophers among the Chinese, are all Atheists; a sort of Spinosists. At least, they believe the world was always as it is now. $-L$.

The Chinese classies are their ancient writers of two thousand years standing, and upwards, that have given some account of their history ; and settled the first principles of their religion. Some people talked of them as if they would make five large volumes in folio, but they who are better acquainted with them say that the copy of them all together is not bigger than the Pentateuch.- $L$.

Most of the missionaries deserve but little credit; they have falsified often, and have been discovered in some of their cheats. I think it was in the calculation of a comet or eclipse, however in some very nice calculation, sent from China to Rome, the learned there were strangely surprised to find it agree exactly with one by Tycho Brahe: whereas 
the best of our European astronomers generally differ as to a few minutes at least. This was much talked of there at first, till it was discovered some time after, that the missionaries at Pekin had corrected and set this caleulation by Tychos. $-L$.

Moses did not write witl a view to all the world, but for one people; to establisil their religion and polity: and this is the best key to let us into the meaning of his writings. Thus, for instanee, in the history of the fall : I don't question but that Adam had a larger law given lim than we hear of, but Moses may have particularized in the breach of a positive order, beeause the religion he was to establish was all ritual.- $L$.

Where we translate it, " the Lord set a mark upon Cain," the original signifies a token; and in the Hebrew, to set a token upon anything, and to preserve it, are equivalent expressions.- $L$.

The same word in Hebrew signifies blessing and cursing, as they say in Italian : "tu è benedetto ;" you are a eursed raseal._Where we make Job's wife advise him to curse God and die; it should be, Bless Gool and die; bless him for the gool you have hitherto received; and die, to avoid the evils that are now come upon you.*-L.

To call by their names was an expression, among the Hebrews, equivalent to the being master or having dominion over anything. Thus God is said to call the stars by their names; and Adam to liave given names to all animals. $-L$. The one book necessary to be understood by a divine, is

- She, as everybody then did, lorked on this life as the ultima tum to man. This sense of the passage is plain from the context. -Addition from MS. $B$. 
the Bible; any others are to be read, chiefly, in order to understand that.-One must not read it through a system, as a perspeetive, but bring our systems to our Bible; and not our Bible to our systems, as most divines (in every ehurch) are too apt to do.- Try to see its first natural sense, and eonsult comments afterwards; and that only where the nature of the thing makes them neeessary.

The most general, and the greatest difficulty, in understanding the true sense of the Scriptures, arises from our not knowing the proportion between the ways of speaking used in the east, and those in such a northernly eountry as our own. An Italian would not stiek at ealling that little parterre, with two rows of trees about it, a Paradise; and my villa in the eountry, a magnifieent palace. As we are aequainted with their way of speaking, we know very well that they mean nothing by this, but a pretty little garden, and a tolerable house; but if any one less aequainted with their way should take it literally, and assert, in plain honest English, that I was master of a magnificent palace, and that my garden was equal to the garden of Eden; nothing could well be more ridieulous. Now the disproportion between our ways of speaking and those of the orientalists, is mueh wider at present (and was still more so formerly), than between our plainness and the Italian hyperbole. $-L$.

It is not at all improbable that Sir Isaae Newton, though so great a man, might have had a hankering after the French prophets.* There was a time when he was possessed with the old fooleries of astrology; and another when he was so far gone in those of chemistry, as to be upon the hunt after the philosopher's stone.- $L$. 
In all my travels I never met with any one Seotehman but what was a man of sense: I believe everybody of that country that has any, leaves it as fast as they ean.- $L$.

[ lreland a noble country if it were cultivated, and would, perhaps, be the best in the world for trade, if made the great mart of it. $L$ L. Addition from MS. B.]

The English abroad ean never get to look as if they were at home. The Irish and Scoteh, after being some time in a place, get the air of the natives; but an Englishman, in any foreign court, looks about him as if he was going to steal a tankard.- $L$.

Upon the death of the queen (Anne), Ormond, Atterbury, and Lord Marshal, held a private consultation together, in which Atterbury desired the latter to go out immediately, and proclaim the Pretender in form. Ormond, who was more afraid of consequences, desired to communicate it first to the council.- " Damn it, sir," said Atterbury in a great heat, (for he did not value swearing, " you very well know that things have not been eoncerted enough for that ret, and that we have not a moment to lose."--Indeed it was the only thing they could have done: such a bold step would have made people believe that they were stronger than they really were; and might liave taken strangely.The late king, I am fully persuaded, would not have stirred a foot, if there had been a strong opposition: indeed the family did not expeet this erown; at least nobody in it, but the old Princess Sophia.- $L$.

The Prineess Sophia was a woman of very good sense, and exeellent conversation. I was very well aequainted with her. She sat very loose in her religious prineiples; and used to take a particular pleasure in setting a Free- 
thinker (whenever she could meet with such) and one of her ehaplains a disputing together. [As somebody does now.*]- $L$.

No one will ever shine in conversation, who thinks of saying fine things: to please, one must say many things indifferent, and many very bad.- $L$.

Large eommon-plaeing teaches one to forget, and spoils one for eonversation, and even for writing. $-L$.

When we write in a foreign language, we should not think in English ; if we do, our writings will be but translations at best. If one is to write in French, one must use oneself to think in French; and even then, for a great while, our Anglieisms will get uppermost, and betray us in writing, as our native accent does in speaking when we are among them.- $L$.

Though the Dean is the best of eompany, and one of the liveliest men in England of his age, he said (when in no ill-humour), "The best of life is but just tolerable; 'tis the most we can make of it." $-L$. [He observed that it was very apt to be a misfortune to be used to the best eompany : and gave as a reason for his not marrying, that he had always been used to eonverse with women of the higher elass, and that he might as well think of marrying a princess as one of them.- " A competenee enables me, single as I am, to keep as good eompany as I have been used to, but with a wife of this kind and a family what should I have done?"]-Addition from papers.

Let your great endeavour be, to get an independency.- $L$. If a person would travel for three months (to get the

* Plain from what was afterwards said to be the queen ; (i. e. Caroline wife of George the Second.)-Addition from MS. $B$. 
Freneh language and qualify himself for a larger tour), tho whole expense need not be alove fifty pounds. Orleans would be the best place, or Caen. If you take a friend with you, 'twill make you miss a thousand opportmities of following your end. You go to get French; and it would be best, if you eould aroid making an aequaintance with any one Englishman there. To converse with their learned men, will be beside your purpose too, if you go only for so short a time; they talk the worst for conversation, and you should rather be with the ladies. $-L$.

Holland settled itself, in a little time, in opposition to one of the most powerful monarehs then in the world: and Rome was a long time in forming its state to any size in opposition to only petty neighbours.- $L$.

It is strange that Harrington (so short a time ago) should be the first man to find out so evident and demonstrable a truth, as that of property being the true basis and measure of power. His Oceana, allowing for the different situation of things (as the less number of lords then, those lords having no share in the parliament and the like), is certainly one of the best founded political pieces that ever was writ.- $L$.

Our Gothic aneestors were very great men, and of great capacities. They were the first that established in faet, what Aristotle had only touched in theory: I mean their exeellent institution of limited monarchies. The Asiatic monarchies were absolute, and the greatest republies of antiquity were very defective.-Greece was split into too many little distinet powers, as Holland is at present, which were always jarring with one another, unless when held together by the pressure of some powerful common enemy. 
-Rome, whilst a republic, was searce ever free from distractions between the patricians and plebeians for ten years together.-Whatever is good, either in monarehies or republies, may be enjoyed in a limited monarchy. The whole foree of the nation is as ready to be turned one way, as in monarehies; and the liberties of the people may be as well secured as in republies. $-L$.

The Jews offered my Lord Godolphin, to pay five hundred thousand pounds (and they would have made it a million), if the gorernment would allow them to purchase the town of Brentford, with leave of settling there entirely, with full privileges of trade, \&c. The agent from the Jews said, that the affair was already eoneerted with the chiefs of their brethren abroad; that it would bring the richest of their merchants hither, and of course an addition of above twenty millions of money to circulate in the nation. Lord Molesworth was in the room with Lord Godolphin, when this proposal was made, and as soon as the agent was gone, pressed him to elose in with it. Lord Godolphin was not of his opinion. He foresaw, that it would provoke two of the most powerful bodies in the nation, the elergy and the merchants; he gave other reasons too against it, and in fine it was dropped. $-L$.

The Jews had better suecess with Oliver Cromwell, when they desired leave to have a synagogue in London. They offered him, when Protector, sixty thousand pounds for that privilege. Cromwell appointed them a day for his giving them an answer. He then sent to some of the most powerful among the clergy, and some of the chief merchants in the city, to be present at their meeting. It was in the long gallery at Whitehall. Sir Paul Rycaut, who was then 
a young man, pressed in among the erowd, and said he never heard a man speak so well in his life, as ('romwell did on this oscasion. When they were all met, he ordered the Jews to speak for themselves. After that he turned to the elergy, who inveighed much against the Jews, as a cruel and eursed people. Cromwell in his answer to the elergy called them "Men of God ;" and desired to be informed by them whether it was not their opinion, that the Jews were one day to be ealled into the ehureh? He then desired to know, whether it was not every Christian man's duty to forward that good end all he could? Then he flourished a good deal on the religion prevailing in this nation, the only place in the world where religion was taught in its full purity: was it not then our duty, in partienlar, to encourage them to settle here, where alone they could be tanght the truth; and not to exclude them from the sight, and leave them among idolaters? This sileneed the clergy. He then turned to the merchants, who spoke much of their falseness and meanness, and that they would get their trade from them. "'Tis true," says Cromwell, " they are the meanest and most despised of all people."-He then fell into abusing the Jews most heartily, and after he had said ererything that was contemptille and low of them: "Can you really be afraid," said he, " that this mean despised people should be able to prevail in trade and credit over the merchants of England, the noblest and most esteemed merchants of the whole world :"-Thus he went on, till he had silenced them too; and so was at liberty to grant what he desired to the Jews.-L. (Who had this from Sir. P. Ricant himself; as he had the former from Lord Molesworth.)

The King of Sardinia made an absolute act of Mortmain, 
some years ago, and was much for humbling the clergy. He took the education of children too out of the hands of the Jesuits, and none but secular priests can teach them in his dominions. Had our late Regent lived a few years longer, I dare say we should have seen at least as bold steps taken among us.-Mons. Legris, at Lyons.

One of the greatest liberties of the Gallican church, is, that no bull, or order whatever, sent by the Pope, is looked upon as any way valid among us, till it lias first passed the king, and then the parliament. By this means (for instance), the King of France can never be excommunicated, as to his own subjects; and the parliament can stop anything they dislike.-The present Pope (Clement XII.), sent his bull for a jubilee, on his promotion to the see; with pardon to all, except the Jansenists. The parliament did not like this exception, and sent the bull back for amendment; that was refused, and so they had no jubilee at all. -Mons. $L$.

Our Religieux, are such ecelesiastics as live in their regular houses, according to their several orders; Chanoins, such as serve in particular churches: Curés, are those who have parishes under their care; and Vicaires, their assistants. Our Abbés are of two sorts, grands et petits: the formcr, are governors of houses; and the latter, ecclesiastics in the world, and without cure.-Mons. $L$.

'Tis the general maxim of all our colleges, to choose a man of management for their head, rather than a man of letters.

In speaking of Benedict XIII. he said, that " he was a good man, a mediocre bishop, and a bad pope."-Père de Colonia, of the Coll. of Jesuits, Lyons. 
The government of Geneva is partly aristoeratic and partly demoeratic. The liberty of the people is, really, very considerable: it consists in our having no magistrate over us, whom we do not choose ourselves, and no law to which we do not give our eonsent.-The Assembly of Citizens (about fifteen or sixteen luundred in number), nominate persons out of their own body to supply the vaeancies in the eouncil of two-hundred. The two-hundred nominate twenty-five of their members for the Syndieship or ehief of office; out of whieh twenty-five, the Assembly of Citizens again eleet the four Syndies.-We have but one book of laws, so small, that you may hide it in your hand, and we have not had any new law made these hundred years.Law-suits are not common amongst us, and the trade of quarrelling meets with small encouragement.--Our advocates (or pleaders), are tied down to a certain and very low pay; yet we have about fourscore of them; because it is necessary for any one to have been an adrocate, in order to qualify him for the holding any of the elief posts in the republie.-Mons. Cramer, one of the Professors at Geneva.

Our ecelesiastieal polity in Holland, is, in my opinion, preferable to yours in England on several aecounts.-First, in the people's having a share in ehoosing their own teachers for themselves.-Secondly, in the clergy's not being so subject to intrigue, rivalship, and fawning for preferments as they are with you.-Thirdly, in the greater equality of their ineomes, which renders them less subject either to pride or contempt. No clergyman, in the Province of Holland, has less than forty pounds a year; and no one more than two hundred and forty pounds.-Fourthly, in the manuer of receiving their income, in settled sums quarterly, 
from the magistrates; which lessens their coneern about temporal matters, and prevents all law-suits, and disputes with their parishioners.-Fifthly, in their being wholly uneoncerned with the civil government, which keeps them out of party quarrels, and gives them more time to attend to their proper employment.-M. Soyer.

When there was that great fire in the seraglio at Constantinople, about fifty years ago, a great portion of the furniture, and, among the rest, several books were flung into the street. The seeretary of the French embassy, then at the Porte, happened to be walking that way, and as he was getting as well as he could through the crowd, he saw a man with a large folio volume, which he had opened, but could not tell what to make of it. The seeretary saw it was a mannseript of Livy, and on turning over the leaves a little further, found that it had the second deeade, as well as the first, and probably might have all that is lost to us. He offered the man a handsome reward if he would keep the book under his long robe, and follow him with it to his lodgings. The man agreed to it, and followed him; but, the crowd and confusion increasing, they were separated, and so the secretary lost the recovery of so great a treasure as this would have been to the learned world.- $S$.

At a convent ( $I$ think it was of Benedictines), at Caen in Normandy, they keep an exact terrier of all the lands, which formerly lelonged to the monks of that order, in England; in hopes it may be one day of use to them.-Mr. Clark. [Who san the writings in their possession.]

The grandees in Spain are extremely ignorant. There is searee anything like taste among them. Even in the king's palaces, they have cut some of the finest pictures, 
that they formerly brought out of Italy, only to fit them to the places where they are hung; so that you shall see the upper part of a capital piece, perhaps, over one door, and the remainder of it, over another. [The French General we met upon the Alps, returning from LAadrial to Rome.]

Pray observe with what ease the passions are expressed in that face:-Our statuaries now are foreed to distort the features, to show a passion; their strokes are all violent and foreed.-This will help you, as much as anything, to see the superiority of the best ancient seulptors over the moderns. We have no one, exeept Michael Angelo, that eomes near them.-The Marquis Maffei, at Verona.

The French pretend to rival our musie, and seem to forget that they were obliged to us for their own. Some of our musicians, who resided in their country, helped them to the sort of music they have; and formed it, not on the true prineiples of harmony, but so as to hit their particular taste. What musie they have, such as it is, is a scion from our tree.*-The same.

When I was young, I published a piece ealled Ninfu Fidele; was I to write anything of that nature now, it should be Vinfic Infirla: that title would have been more just; at least, I am sure I have found them so._-The same.

Most of the statues in the great Farnese Palace, were found in Caracalla's Baths, and all the marble of which it is built, was brought from the Colosseum, in Paul the Third's time, a pope of that family.-Sign. Ficoroni, at Rome.

The Ichnography of Rome, in the same palace, $\uparrow$ was found in the temple of Romulus and Remus, that which is

* Une feuille de notre arbre, were his words.

$\dagger$ It is now removed to the noble collection in the eapitol. 
now dedicated to St. Cosmo and Damiano, two brothers too.-Though ineomplete, it is one of the most useful remains of antiquity. The names of the partieular buildings and places are marked upon it, as well as the outlines of the buildings themselves ; and it is so large, that the Horrea Lolliana (for instance), are a foot and a half long; whieh may serve you as a seale, to measure any other of the buildings or plaees in it. 'Tis published in Graevius's Thesaurus. $-F$.

The two best Egyptian statues in Rome, are the Hereules with a lion's skin over his head, in the eapitol; and the rieher Zingara, at the Villa Borghese. You may know them to be Egyptian by that fulness about their mouths.*-F.

This large statue of Pompey was probably the very same at the feet of which Cresar fell ; for it was found on the very spot where the senate was held on the fatal Ides of Mareh. They diseovered it in elearing away the ground to make some cellars for a house that now stands there. The greatest part of the statue lay under that house, but the head of it reached under the ground belonging to their next neighbour. This oceasioned a dispute between the two proprietors, whieh was at last deeided by Cardinal Spada. He ordered the head to be broken off, and given to the latter; and the body to the former: you may now see the mark where they were joined again. This decision was not made out of a whim, but very prudentially. From the first, that cardinal had a great desire to get the statue into his own possession, and by this means, he got it much cheaper than he could otherwise have done: for after this division of it, the whole eost him but five hundred crowns. $-F$. at the Palazzo Spada in Rome.

* Per oris.luxuriem, was his expression. 
That arm, behind the Laoeoon, was begun by Michael Angelo, and he left it unfinished, "beeause, (as he said,) he found he could do nothing worthy of being joined to so admirable a piece." It lies there as a testimony of the superiority of the best ancient artists over the modern; for, of all the modern sculptors, Miehael Angelo is universally allowed to be the hest. $-F$, at the Belvedere in the Fatican.

When they first diseorered the Verospi statue of IIercules killing the hydra, some parts of it (and particularly that monster itself), were wanting, and were supplied by Bernini. Some years after, in further digging the same piece of ground, they found the hydra that originally belonged to it, and whieh differ's very much from Bernini's supplemental one; thongh that is given in Maffei's book of statues, and other books of prints, as antique. It is now removed from the Verospi palace to the eapitol; and the original hydra, with a horned sort of human face, snakes for hair, and a serpentine body, is there too, in the same little court where Marforio lies. $-F$.

The arts are greatly fallen among us of late, and there is nothing we exeel in so much, at present, as the works in Mosaie. They are in greater perfection than they ever were, even among the ancients. In their works of this kind (as to what liave been hitherto diseovered), the design is often good, but the colouring indifferent, or rather bad. They used nothing but stones with their natural colours, and we use a paste or composition which does not only represent all the principal colours in a strong and lively manner, but all the different shades and degrees of each, as far as they are wanted.-The composition for Mosaie work consists of glass, stannum, and lead; it is formed into little oblong 
squares, and ranged aceording to their different colours and shades, not unlike our manner of disposing types for printing. These Mosaie types are coloured througlout, and are stuek in their proper places, in a sort of soft stueco, spread over a stone (which is eut rough on that side), of the size of the picture. When the types are all set, they can smoothen it to the thinness of a shilling, and this smoothing makes it look all of one piece in a proper light and distance, as much as a picture. They don't want for encouragement in this art, for the price bears proportion to the exeellence of the work. They ask a thousand erowns for that little oval piece of Fame, and are to have fifteen thousand crowns for the copy of Dominichino's St. Jerome when finished. Indeed the work takes up a vast deal of time, for they have been four years about that piece already. $-F$. (and Christoferi, the principal Mosaic artist at that time.)

The diameter of that part of Augustus's mausoleum, which is still entire, (and which was the largest round of all,) is fifty paces. In it were deposited the ashes of Julius Cæesar, Augustus himself, Marcellus, and Germanicus. The tomb of Adrian (now the eastle of St. Angelo), was built on the opposite side of the Tiber, to rival this, and is the largest of our ancient mausoleums. It was riehly adorned too with fine statues, all round each particular rising; which in the Gothie times were thrown down by the Romans, that had fortified it, to defend themselves and crush their enemies. $-F$.

The Roman matrons of old used to eary their ehildren when ill to the temple of Romulus, which was said to be built on the very spot where he was supposed to be found in his infaney. That temple is now Christianized; and the 
women of Rome still earry their children there on the same ocensions: but the priests now are, perhaps, more emning than they were of old; for whenever they offer a child thus to the now saint of the place, they pray " that he would be so grool as either to eure him, or to take him to himself," so that the parents must always be obliged to them ; and their prayer can never be unsuceessful. $-F$.

When ILenry the Fourtl of France was reconeiled to the Chureh of Rome, it was expected that he should give some remarkable testimony of his sincerity in returning to the true faith. IIe accordingly ordered a cross to be erected at Rome, near the ehurch of Santa Maria Maggiore; with this inseription: In hoe signo vinces, on the prineipal part of it. This passed at first for very Catholic, until it was observed that the part on which the inseription was placed, is shaped in the form of a cannon; and that he had really attributed to his artillery, what they had taken to be addressed to heaven. $-F$.

The floor of the Rotunda is so much raised, as to hide all the pedestals of the columns in the inside. There was formerly a round of the imaginary figures of the provinees conquered by the Romans, in relievo, one against each pedestal; which were taken away, when the floor was raised, and are now dispersed about in the capitol, and other collections at Rome. $-F$.

There are three sorts of Egyptian statues. First, Those that are good without any mixture of their bad taste; and this manner is very aneient, before they were eonquered by the Greeks. Secondly, After they were conquered, and their spirits debased, they made the figures of their deities frightful, on purpose to keep the people in awe; and this 
was the cause of their bad taste, some parts out of nature and some in. Thirdly, As everything is apt to degenerate and grow worse and worse, when once fallen; they at last, in many of their figures, deserted nature entirely; and made every part monstrous and ont of all proportion. $-F$.

Dominico Guido was the last of our very good statuaries; he died about fifteen years ago. [We were looking at the Dead Saviour and Virgin by him, at the Monte di Pietà at Rome.]- $F$.

The Monte di Pieta is a bank for charity, established by Gregory the Thirteenth, and improved by his successors. They lend money out of it to the indigent, on pawns of all sorts, without interest, if the sum be under thirty crowns; and but two per cent. if it exceed it. Two years are allowed for payment; if the debtor then fails, this pawn is sold, and the overplus is given to the proprietors. $-F$.

You may know that Hereules to be Roman, by its being so much overwrought: the muscles look like lumps of flesh upon it. The Greek artists were more expressive, withont taking so much pains to express.-F. (At the Palazzo Lancilotti.)

This groupe of Arria and Pætus is evidently by a Greek artist. Though the place he has chosen to stab himself in* be very uncommon, it was not ill chosen; for the blow could not but be mortal, most of the blood running down among his vitals. $-F$.

The most promising of Carlo Maratti's scholars was one Berettoni. He died when he was but two-and-thirty, and not without suspicion of foul play from his master, who

* It is a very bold stroke, and takes away the false idea one might have got of him, from the well known epigram in Martial. -spence. 
could not bear to have one of his scholars excel himself. That he evidently did so may be seen by compraring both their works in the Palazzo Altieri.*-F.

Dominichino is in as high esteem now as almost any of the modern painters, at Rome. When you see any works of his and Guido's together, how much superior does he appear! Guido is often more showy ; but Dominichino has nore spirit, as well as more eorreetness. (Più spiritoso was his word.) $-F$.

This Leda (at the Palazzo Colonna) is said to be by Correggio; but there is not one undoubted pieture of that great master in all Rome.-F. or Mr. Knapton.

When M. Aurelius's triumphal areh was taken down, to give more space to the Corso, the relievos on it were carried to the eapitol. These are the six compartments of M. Aurelius pardoning the vanquished in his triumphal ear ;-saerifieing;-receiving the globe from the genius of Rome;-Lueius Varus haranguing; - and Faustina ascending to heaven.-F.

The brass wolf suckling Romulus and Remus (now in the eapitol), was found in the temple of Romulus; and the marks are visible upon it where it has been struck with lightning. Cicero speaks of the same aceident happening to sueh a figure in his time (in his third Oration against Catiline); and this must have been made before his time by the badness of the workmanship. $-F$.

I measured the Tarpeiau Rock, when the Duke of Beau-

- There are two altar-pieces in one of the churches called the Gemelli (just as you enter Rome), one by Carlo Maratti, and the other by this Berettoni; the latter of which is of a darker, graver, and better manner, than that of his master.-Spence. 
fort was here, and found it to be eighty palms high, which just answers to sixty feet English. It goes down perpendicular as you see; and so was easily measured. I took only the height of the rock itself, exelusive of the building that has been added upon it.- $F$.

Mr. Addison did not go any depth in the study of medals : all the knowledge he had of that kind, I believe, he had from me; and I did not give him above twenty lessons upon that subject. $-F$.

The fine statue of Jonas, in the church of Santa Maria del Popolo, was made by Lorenzetto, after a design of Raphael's: and it is remarkable that Jonas, who seems to have been by mueh the most hot-headed of all the prophets, is represented as much the youngest of them too. His likeness to Antinous, both in his make and youth, is visible to everybody. $-F$.

Caraealla's baths are the most perfect remains of the kind at Rome, and the most eapable of giving us an idea of the aneient Thermce. The roofs, where left, eonsist half of pumice-stone, for the sake of lightness, in such large arehes. The niches are very perfect in some squares of it; but in the most perfect parts there is nothing to be seen of windows. The Jesuits begged it for their boys to play in ; and have since sold a good deal of the stone; and often dig for statnes in it. $-F$. [They had been digging the very week before we saw it, and had brought up several broken pieces of statues, \&e.]

The front pillars of the Temple of Coneord, those of Antonine and Faustina, and those of the Rotunda, are the most perfect of any in Rome; and in each of them, the opening between the two middle pillars is larger than the 
openings between the side ones. The differenee is not enough to be observed by a common eye; and in some of them not to be sure of it till you measure them. By this means the entrance had a freer and nobler air, without breaking the regularity and harmony of the building.Mr. Phitips.

It was Sixtus the Fifth that began the palace on Monte Cavallo, and placed the two large equestrian statues there, from whence it has its name. They were found in Constantine's baths, and were brought originally to Rome from Alexandria. The names of Phidias and Praxiteles on the bases are certainly fictitious, and some of the antiquarians say, that they were put there by the people of Alexandria. -Ficoroni.

The chief ornaments of Constantine's triumphal areh are spoils from one of Trajan; as it was despoiled itself afterwards, (of the heads of the statues,) by Lorenzo de' Medici. There is at least seven feet of it hid, by the rising of the ground. $-F$. [They began refitting it afterwards, while we were there, and the relievos on the lowest part were very mean : bad victories, \&c.]

Trajan's column is composed of twenty-four stones only ; cut within, for the stairease. It is one hundred and twentyeight Roman feet high, just the height of what was taken from the hill, to make room for Trajan's forum; which was one of the most magnificent things in Rome. This column stood in the midst of it, and on that was his statue, and, they say, his ashes in an urn.-F.

The four most celebrated works of the modern sculptors in Rome are Michael Angelo's Moses; Algarli's Story of Attila ; Fiamingo's Susanna; and Bernini's Bibbiana.-F. 
What they point out as the four most celebrated pictures, are, Raphael's Transfiguration; Volterra's Descent from the Cross; Dominichino's Saint Jerome; and Andrea Sacchi's Romualdo. $-F$.

There are ten thousand six hundred pieces of ancient sculpture of one sort or other now in Rome; (relievos, statues, and busts.) And six thousand three hundred ancient columns of marble. What multitudes of the latter sort have been sawed up for tables, or wainscoating chapels, or mixed up with walls, and otherwise destroyed! And what multitudes may there yet lie undiscovered under ground! When we think of this altogether, it may give us some faint idea of the vast magnificence of Rome in all its glory. $-F$. 


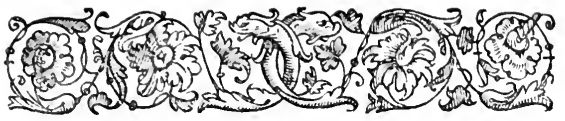

\section{SPENCE'S ANECDOTES.}

\section{SECTION III. 1732-33.}

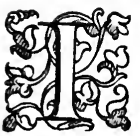

INTEND to publish all the most select and sacred books of the Clinese, in one volume, which will not be so mueh as the Pentateuch. $-A$ Latin translation of their family ritual, with a dissertation of their funerals prefixed to it.-A treatise to prove that the eharacter Tao signifies the great God: in this I shall show; First, That their Tao is one and three. Seeondly, That he created the material world. Thirdly, That he created all intelligent beings. Fourthly, That he was incarnated. Fifthly, That though he has the attributes of whatever is exeellent, yet he is but one. They call him Ching Gin, or the Holy One. Besides these I shall publish " The Temple of the most Aneient Wisdom," in whieh I shall slow that Adam was informed of the doctrines of the Trinity and Future Redemption: that this knowledge was delivered down to Moses and revived by him; that it was preserved in other mystie books, and that several of these books are still preserved in China. I also intend to republish my Chronological Table, with an 
aecount how to manage it.*-M. Fauquet, Bishop of Eleutheropolis; then resident in the College of the Propaganda at Rome.

There are about thirty-five thousand houses in Rome; twenty-three thousand of which belong to the religious orders. The Pope ean suppress any religious society if he pleases, so that all their property is in his power.-His usual way of rewarding those whom he is under obligations to, is by assigning them a pension on one of these religious societies; and as he ean thus tyranuize over them, he allows them to tyrannize over their dependents in their turn.-Ficoroni.

Dante wrote before we began to be at all refined; and of eourse, his eelebrated poem is a sort of gothie work. He is very singular, and very beautiful in his similes; and more like Homer than any of our poets sinee. He was prodigiously learned for the times he lived in ; and knew all that a man could then know. Homer, in his time, was unknown in Italy; and Petrarea boasts of being the first poet that had heard him explained. Indeed in Dante's time there was not above three or four people in all Italy that could read Greek: (one in particular at Viterbo, and two or three elsewhere.) But though he had never seen

* A long article of M. Fauquet's upon Chinese learning is omitted here, because better printed accounts are before the public.-Editor.

I got this list of his intended publications at the desire of M. Ramsay; and observed at the time that he was working on so many designs together, that $I$ feared he would never finish one of them; which proved to be the case. The bishop brought out of China near four hundred of their books, but lost almost half of them before he reached Europe.-Spence. 
Homer, he had conversed much with the works of Virgil. - His poem got the name of Comedia after his death. He somewhere ealls Virgil's works Tragedie (or sublime poetry); and in deference to him, called his own Comedia (or low): and henee was that word used afterwards, by mistake, for the title of his poem.-Dr. Cockhi, at Florence.

Dante, Galileo, and Machiavelli, are the three greatest geniuses that Florence has ever produced.-Dr. $C$.

Petrarea is the best of all our lyric poets; though there are several now who are very strenuous in preferring Chiabrera to him. It has divided the wits into two parties, they are ealled Petrarehists, or Chiabrerists, according to the side they take. The dispute turns wholly on their lyric pieces.-Chiabrera is not so equal a writer as Petrarch: some of his odes are extremely good; and others full of false thoughts. Those which are his best are lofty, and full of fire, after the mamer of the Greeks.-Petrarca's language is excellent; and reads extremely well, even though you should fling it into prose. His poetry is often fine, soft, and moving; but he is not without his false thoughts (concetti) too sometimes.- $D r$. $C$.

Tasso followed Ariosto too much in his particular faults; so that they are a good deal alike so far: but he was more classically read, and especially in the old erities. He endeavoured also to write on a more correct plan. Sperone brags of finding out and disposing the subjects for him.Ariosto loved the elassies too; and, in particular, understood Horace better than any man in his time. When he first came to Rome, Bembo, and several of the greatest wits there, were endeavouring to get to understand Horace. Ariosto joined them; and they all allowed him to have a 
greater insight into that anthor than any of them.- " I believe he did not understand Greek." "No, sir ;" and he owns it in a letter to Bembo.-Ariosto was a vast master of poetical language; his imagination is strong, and his deseriptions often extremely lively and natural. He wrote his Orlando to divert himself: and did not eare whether he was eorreet or no.* The great Galileo used to eompare that poem to a melon field: "You may meet with a very good thing here and there in it (says he), but the whole is of very little value." $-D r$. $C$.

Ariosto, Boiardo, and Berni, have written all on the same subject, the siege of Paris; and took it from an old prose romance called I Reali di Francia: as the aneients used to write in droves, on the siege of Thebes, or the siege of Troy.-Dr. $C$.

[In speaking of their Latin poets, he mentioned Vida, Sannazaro, and Fracastorio ; but went no farther.-Spence.]

Folengo's Poem is written in mixed language: Latin, with several of the words Italianized; as the Fidenzian $\dagger$ is Italian Latinized. Macaronic Poetry is the general name for both of them; or any other such confused ridiculous stuff.-Dr. C.

* This is at variance with the accounts given by the biographers of Ariosto, who represent him as very solicitous about the correctness of his poem; indeed the alterations and corrections which he made in each subsequent impression during his life afford sufficient proof of it. He was engaged in revising it for a new edition at the time of his death.-It is in one of his Satires, addressed to Bembo, that he laments having lost the opportunity of learning Greek from Gregoris of Spoleto, his preceptor.-Editor.

† The Italians sometimes call this lingua pedantesca. I believe the name above mentioned is taken from that of Fidenzio Glottochrysio; the sobriquet of the first inventor of it.-Editor. 
Berni's way of writing is genteel;* and the introduetions to each eanto in particular are very beautiful. ( $I$ preamboli sono superbi) were his words. - Di. C.

Lippi's Mahnantile Raequistato is very good. Though it is a mock-epie, his style is that of 'Tasso, Petrarea, and the best Tusean writers : for the eommon people in Florence talk the language of the nobility and gentry; $\uparrow$ it is not there as it is in the other eities of Italy.-Dr. C.

Mauro has written on low subjeets, in the common genteel style; but Cruileli is the first among us that has ever attempted to treat of low things in the high epie manner. I gave him the hint from Mr. Pope's Rape of the Lock; and what is handed about of his, in that style, has pleased extremely.-Dr. $C$.

Why are the Italians, who are a grave solid people, the most fond of drolleries on their stage ; and greater dealers in burlesque than any other nation?--Salvini used to say it was, beeause when people have a mind to divert themselves, they generally ehoose what is most different from their ordinary temper and praetice, as most likely to divert them. That may be the reason, but I should not be apt to aequiesee in it.-Dr. C. [Perhaps he thought their gravity was a eheat; and ridieule their natural bent. On the other side, it is evident that most of their drolleries are very low, and violent. There is the same difference between fine drollery and theirs, as there is between true

- Probably Mr. Spence thinks this a correct translation of the Italian gentile.-Editor.

$\dagger$ But see what a late intelligent and amusing traveller (Mr. Stewart Rose) says on this subject, it is quite at issue with this piece of information, and probably , $_{\mathbf{b}}$ uch nearer the truth.-Editor. 
and false wit. This would rather incline one to think that they are really grave, and only affeet gaiety; beeause they pursue it so boisterously and so injudieiously.-Spence.]

Perfetti was crowned about four years ago, for his talent at improvisoing, or making extempore verses: but Manfredi is the best poet we have now in Italy.- " I thought the impromptu-way had prevailed all over Italy, and was regarded as the highest exeellence of poetry at present?" -No; it is only admired so much by the little and great Vulgar.-Dr. C.

Our not having any settled stage for tragedies in Italy, is a great blow to our dramatic poetry. . The actors indeed that stroll about from eity to eity, do now and then aet a tragedy: but even when that happens, and the king of the play is seated on his throne, it is ten to one but you see a harlequin eome upon the stage, and place himself just by him.-Dr. C.

By a ealculation made from the best dietionary for each of the following languages; there are about twenty thousaud words in the Spanish, twenty-two thousand in the English, twenty-five thousand in the Latin, thirty thousand in the French, forty-five thousand in the Italian, fifty thousand in the Greek, and eighty thousand in the German.* Of the twenty-two thousand worls in the English language, there are about fifteen thousand words that a man understands who is before a master of Latin, Freneh, and Italian: and three thousand more, if he be master of

* Note by Mr. Spence from papers.-One thousand seven hundred radical words, according to Buxtorf, three hundred and sixty Chaldaie words in the Bible, according to Bythner, and two thousand and sixty in all.-Mr. Hill. 
German. The other four thousand are probably the old British.-DIr. C.

When the English were good Catholies, they usnally drank the Pope's health in a full glass after dinner : au bon pere; whence your bumper.-Di. C.

As cumning as old Nie, and as wicked as old Nie, were originally meant of our (Nicolas) Machiavelli : and eame afterwards to be perverted to the devil. - Di. $C$.

Machiavelli has been generally ealled so wieked, from people's mistaking the design of his writings. In his Prinee, his design, at lottom, was to make a despotie government odious. "A despotie prince, (says he,) to secure himself, must kill such and such people:"-he must so: and therefore no wise people would suffer such a prince. This is the natural consequence; and not that Machiavelli seriously alvises princes to be wicked.-Di. $C$.

The best traditions concerning Maehiavelli are, that he was a good honest man himself in his way of living ; rather weak and ignorant in his private affairs than otherwise. Ifis familiar letters are now in the hands of the $\mathrm{A}$ bate del Riecio, at Florence; and there are several things in them that slow lim to have been a good sort of man. He kept the best eompany; and consorted with good men. We have several soeieties of men in Florence, who (though they are of no religious order) profess a greater strictness, and a higher love of religion than ordinary; they are a sort of voluntary religious soeieties: Machiavelli belonged to one of these confraternities. They used to meet once a week, for devotion, in a chureh of theirs; and (among other good things) one of the society made a moral discourse, or sermon to the rest. There are several of these 
discourses, of Machiavelli's composing, in the same Abbe's hands, and one in the great Duke's, on Repentance (in lode della penitenza), which were spoken by him in the confraternity he belonged to.-Dr. $C$.

[Signor Sbarra, at Lucca, did not carry this point so far, he only said, "that Machiavelli advised politicians to be good, that was their best and easiest way; but if they must be bad, he laid down rules how they should be so most wisely and politically."-Spence.]

Lord Burlington was so much for Palladio, that he used to run down Michael Angelo. 'Tis true the latter did not follow the rules so much as the former, but then he had a more correct eye, and is universally reckoned the best architect of the moderns, by the best judges, at Rome, as well as at Florence.- $D r$. $C$.

It was objected to Copernicus, in his own days, that if his scheme was true, Venus must appear to us with different phases, just as the moon does. "So she would, I believe," replied he, "if we could see her aright." This was a noble guess for the time, and what has proved to be actually the case, since Galileo has found out new eyes for us.Dr. C.

Kepler (a German), carried things rather further than Galileo. It was he that found out the gravitation of the planets, but not the proportions of them.-Dr. $C$.

Cardinal Barberini had made some of the objections to $\mathrm{Ga}-$ lileo's scheme, that are jut into the mouth of Simplicius, (the foolish character that personates the Aristotelians,) in Galileo's Dialogues. This was one of the chief motives which led to the persecution of so great a man, under this same cardinal, when promoted to the papacy.-Dr. $C$.

The pursuit of the greatest trifles may sometimes have 
a very good effeet: the seareh after the philosopher's stone has preserved ehemistry; and the following astrology so much in former ages, has been the canse of astronomy's being so mueh advanced in ours. Sir Isaac Newton himself has owned that he began with studying judieial astro$\log y$, and that it was his pursuit of that idle and vain study. whieh led him into the beauties of, and love for, astronomy.-Dr. $C$.

When I asked Sir Isaac Newton, how the study of the mathematies thourished in England? he said, "not so mueh as it has done here, but more than it does in any other country."-Di. $C$.

Mr. Locke spent a good part of his first years at the university in reading romanees, from his aversion to the disputative way then in fashion there. He told Coste so, and gave that reason for it to him.-Dr. C.

[Coste gave Cocchi Mr. Locke's physieal eommon-place book; which seemed (by what I eould see of it), more valuable for being in Mr. Loeke's hand, than for the matter contained in it.-Spence.]

I must own, that to my taste, Corregio is the best of all our painters. His pieces are less pietures, than those of Raphael himself.-Dr. $C$.

Tasso's madness, some think, was only a pretended madness. He was eaught making too free with a Prineess of the Duke of Ferrara's family, in which he lived. To save her honour and himself, he from that time (say they), began to play his melaneholy trieks. There is a passage in his Aminta which may allude to this; it is in the end of the first aet, and is spoken by Tirsi, under which character Tasso meant himself.- $D r . C$. 
In all the disputes between the Tusean literati, whether Tasso or Ariosto be the better poet, the debate always runs on the outside. Those numerous pieees are entirely taken up in speaking of the style and eolour of the poetry, and the writers of them seem never to have thought anything of the plan or eomposition. Ariosto's poem is like the richer kind of Harlequin's habit, made ip of pieces of the very best silks, and of the liveliest colours. The parts of it are many of then more beautiful than those in Tasso's poem, but the whole in Tasso is, without comparison, more of a piece and better made.-Dr. $C$. [The word richer was added on Dr. C.'s saying the simile was too low for Ariosto. He added, your Spenser has taken mueh from him.-Spence.

The first four hundred years of the Roman History are supposed to have been fabulous by Senator Buonarotti, and he gives several good reasons for his opinion. He suspeets that Rome, in particular, was built by the Greeks ; as Tarentum, Naples, and several other eities in Italy were. $-D r . C$.

Among all our poets we have not any good love-poet. They all follow Petrarea, and his is not a good love for poetry. Some of Ariosto's rhymes are the best this way, he having formed himself on the aneients, and on Tibullus in partienlar.- $D r$. $C$.

Menzini is generally eonsidered as our best satirist, and Ariosto as the next. I don't speak of my own taste, for I like Ariosto better than the other. Menzini is more like Juvenal, and Ariosto more like Horace.-Dr. $C$.

The Spaniards were at the top of their poetry, under the reigns of Charles the Fifth and Philip the Second. They imitated the Italian poets, and would fain set up Gareilasso 
della Vega for their Petrareh. 'Their poetry is generally bad, and even Lope de Vega's is wretehed stuff.*-Gonzalo Perez's trunslation of the Odysey is rery good.-Di. C.

If you look for a right yood poet amongst us, 'tis what you must look for in rain,-Di. $C$.

If a lady applies to learning among us, and arrives to any eminence in it, she is almitted to her degrees as well as the men. Intonia Maria Bassi was lately made a doetoress at Bologna: and a famons Venetian laily was some time sinee admitted to the doetorate at Padua.-Di. C.

Galen's Book, de Consuctudine, has never been published, exeept in a barbarous Latin translation, drawn off

* This sweeping censure of Spanish poetry is too flippant to pass entirely unnoticed.-Though Spain may not boast of any poet like Dante, Ariosto, or 'Tasso ; yet is she not defieient in such as may rank with any of the minor Rimatori of Italy.-Neither is there much arrogance in comparing Garcilasso della Vega to Petrarca. I know not, indeed, whether it is not doing the Tuscan "Imp of Fame" much honour. The Spaniards can boast of lyric and pastoral poets, though not in number equal, yet in sterling merit superior, to those of Italy. It may be sufficient to mention Manrique, Boscan, Mendoza, Luis de Leon, Francisco de la Torre, Villegas, Gongora, (though spoiled by Italian concetti,) Quevedo, the two Argensolas, Castillejo, and Francisco de Rioja.-The climax of this foolish censure of what he probably did not understand, is Coechi's praise of that insipid and tasteless paraphrase of the Odyssey, the Llyssea of Gonzalo Perez.-But hear what the julicious Sellegel says of the language of this contemned poetry. "The Spanish language is less soft than the Italian, on account of the guttural sounds, and the frequent termination with consonants; but its tones are, if possible, more full, proceed still more from the breast, and fill the ear with a pure metallie resonance. It had not yet altogether lost the rough strength and cordiality of the Goths, when oriental intermixtures gave it a wonderful degree of sublimity, and elevated a poetry, intoxicated as it were with aromatic vapours, far above all the scruples of the sober west."-Editor. 
from an old Arabic one : and that so bad, that it was suspected of never having come from any piece that really was Galen's. The Greek original, or at least a great part of it, is in the Lamentian library, where there are also five or six other Greek physicians which I have transeribed.*Dr. C.

There are three thousand manuscript books in the Laurentian library (including a few printed books equivalent to manuscripts), and in many of them, the works of several authors are bound up together; which they call Catenas. -If you take them singly, there are about ten thousand. -There is no other library so well stocked in three of the best sorts ; physical, mathematical, and poetical, manuscripts. $-D r . C$.

The paraphrases written in the margin of Theodore Gaza's Homer, in the Laurentian library, have been often of particular service to me, when $I$ lave been at a loss to fix the meaning of any passage in that poet.-Di. C.

Operas were at first set on foot by a set of gentlemen, who acted, not for money, but for their own diversion. There was about thirty of them.-When they first came to be acted for money, there was one of the actresses who had one hundred and twenty crowns for acting one season. This was then looked upon as such a rast reward for a singer, that she got the name of La Cento-vinti by it.Signor Crudeli, of Florence.

The good taste for medals continued from the time of Augustus to Adrian's ; that for building to Septimius Sererus.-Baron Stosch, at Florence.

The figure of the famous Pasquin, when entire, was the

* Some of these were subsequently published by Cocchi.Editor. 
same with that by the Ponte Vecehio at Florence.-Maffei, in his collection of statues, No. 42 , gives that tigure, and calls it Ajax supported by his brother. P'oor Pasquin was like to have been confined in the eapitol, by the same Pope who sent Marforio thither: but the marquis, to whom he belonged, prevented it. Ilis descendant is still obliged to pay a certain fine, if any seandal be found fixed to him.Ficoroniand Cocchi.

Marehetti's translation of Lueretius, in blank verse, is the best translation in our language.-Le Sette Giornate. or Creation, of Tasso, is in blank verse too, and is much esteemed by the best judges; but not generally read, because without rhyme.-Crudeli.

What the monk sail of Virgil's Eneid, " that it would make an excellent poem if it were only put into rhyme;" is just as if a Frenchman should say of a beanty, "Oh, what a fine woman that would be, if sle was but painted!"- $-C$.

Camillo Querno was sometimes a dealer in monkish verses. -When he was at the table of Leo the Tenth, one day. some time after dinner, the pontiff said to him, "I Iow eomes it about, Querno, that Bacehus, who was the old inspirer of poets, camnot inspire you?"-Querno immediately answered him in the following couplet:

"In cratere meo, Thetis est conjuncta Lyæo:

Est Dea juncta Deo; Sed Dea major eo."- $c$.

When Doctor Garth had been for a good while in a bad state of health, he sent one day for a physician with whom he was partieularly intimate, and conjured him by their friendship, and by everything that was most sacred (if there was anything more saered), to tell him sincerely, whether he thought he should be ever able to get rid of his illness 
or not. His friend, thus eonjured, told him; " that he thought he might struggle on with it, perhaps for some years; but that he mueh feared he could never get the better of it entirely." Dr. Garth thanked him for dealing so fairly with him, turned the discourse to other things, and talked rery cheerfully all the rest of the time he stayed with them.-As soon as he was gone, he ealled for his servant, said he was a good deal out of order, and would go to bed: he then sent him for a surgeon to bleed him. Soon after, he sent for a seeond surgeon, by a different servant, and was bled in the other arm. He then said he wanted rest, and when everybody had quitted the room he took oft the bandages, and lay down with the design of bleeding to death. His loss of blood made him faint away, and that stopper the bleeding: he afterwards sunk into a sound sleep, slept all the night, waked in the morning without his usual pains, and said, " if it would continue so, he eould be content to live on." - In his last illness, he did not use any remedies, but let his distemper take its course.- He was the most agreeable eompanion I ever knew.*-Mr. Townley, of Townley in Lancashire, (who had this account from Garth himself.)

Gravina, for an Abaté, was a great freethinker.- When he died, all his papers were seeured by the emperor's am-

* Garth has been censured for voluptuousness, and accused of infidelity. Being one day questioned by Addison upon his religious creed, he is said to have replied, "that he was of the religion of wise men," and being urged to explain himself further, he added, "that wise men kept their own secrets."-Pope says of him, in his farewell to London, 1715 :

"___ Garth the best good Christian he Although he knows it not."-Editor. 
bassador at Rome. Among other things, there were notes of his upon the Bible, which, eonsidering his character, one would be eurious enough to sce.-Ile was no poet, and his fire tragedlies are very iullfferent things.-The eritieisms in his Reefione Poetica, are many of them false.-Crudeli.

The Oetave Stanza was first well used by Politian. All the eight rerses are equal, of eleven syllables each: the same alternate rhyme in the six first rerses, and an immediate rhyme in the two last. Tasso's verses are sung mueh all over Lombarly, and particularly at Veniec.-The common tune, to which they sing them, is called, il passo gallo, and sounds something like church musie.-C. [When we were at Veniee, there was a common Gondolecr, that could repeat all Tasso's Gierusalemme Liberata in this manner. Dip where you pleased, show him the top of the page, and he would sing three or four verses on immediately.-Spence.]

The last syllable but one in the Octave verses is always long, exeept in the verses which are called struccioli (or sliding). These end with a dactyl, instead of a spondee; and are of twelve syllables, as the others are of eleven. This affects the whole stanza; for if there is one verse of this kind in it, they must be all so. They were used by Politian sometimes, but are now quite out of fashion.-C.

The improrviso or(extempore), poets in Italy, are actually what they are called. They do it with great emulation and warmth; generally in octaves: in which the answerer is obliged to form his oetave to the coneluding rhyme of the ehallenger, so that all the octares after the first, must be extempore; unless they act in concert together.-Our method is, to create our thought at the adversary's seventh verse. Then we have the idea, the rhymes, the words, and 
the verse to think of, only whilst our opponent is repeating his last line; which we take no manner of notice of at all. We almost always do better the second half hour than the first, because we grow warmer and warmer; to such a degree at last, that when I have improvriso'd a whole evening, I can never get a wink of sleep all the night after.-Signor Vanneschi of Florence, (a celebrated Improvvisatore.)

[The first time I heard these Improvvisatori, I thought it quite impossible for them to go on so readily as they did, without having agreed things together beforehand. It was at Florence, at our Resident's, (Mr. Coleman's,) and when that gentleman asked me what I thought of it? I told him that I could not conceive how they could go on so promptly and so evenly without some collusion between them. He said that it amazed everybody at first; but that he had no doubt of its being all fair : and desired me to be satisfied of it, to give them some subject myself, as much out of the way as I could think of.-As he insisted upon my doing so, I offered a subject which must have been new to them, and on which they could not be well prepared. It was but a day or two before, that a band of musicians and actors set out from Florence, to introduce operas for the first time at the Empress of Russia's court. This advance of music and that sort of dramatic poetry, (which the Italians esteem the most capital parts of virtù,) so much farther north, than ever they had been, under the auspices of the then great duke, was the subject I proposed to them.-They shook their heads a little, and said it was a very difficult one: however in two or three minutes time, one of them began with his octave upon it, another answered him immediately ; and they went on for five or six stanzas alternately, without 
any pause; exeept that very short one, whieh is allowed them by the going off of the tune of the guitar, at the cnd of each stanza. They always improrviso to musie, (at least all that I ever hearl,) and the time is somewhat slow; but when they are thoroughly warmed, they will sometimes call out for quicker time.-If two of these (Suonatori) guitarrers meet in the summer nights, in the very streets of Florenee, they will challenge one another, and improvviso sometimes as rapidly as those in set companies. Their most common subjects are the commendation of their several mistresses; the dispute of two shepherds; or a debate which is the best poet. They often remind one of Virgil's third, fifth, or seventh eelogues; or, what he ealls, the contentions of his shepherds, in alternate verse: and, by the way, Virgil's shepherds seem sometimes to be tied down by the thought, in the preeeding stanza; as these extempore poets are, by the preceding rhyme.-Spence.]

The first time I met the famous Searpellino (Stonecutter) of Settimiano, he got the better of me in improvvisoing. IIe has no learning, but is a great reader; and remember's a vast deal of Petrarea, and some other of our best poets. When we are hard put to it, we sometimes fling in some of the most difficult rhymes we can think of, at the elose of the stanza, to get the better of our rival: and the Searpellino is very notable at that in partieular.- Tranneschi.

Tuscany is the prineipal place for extempore poetry; particularly Florence, Sienna, and the country for five or six miles round them. There are a few indeed at Rome; but even those are ehiefly Tuseans.- $V$.

The Cavalier Perfetti of Sienna, is the best improvvisatore at present in Italy. He was crowned in the capitol about 
five years ago, ${ }^{*}$ by order of the Pope; at the desire of the Princess Violante, widow to Ferdinand Prince of Tuseany. He has laid in a heap of different sorts of learning (una grande infarinatura di tutte le scienze), and has an extraordinary fluency of language: but is rather a versifier than a poet. He is so impetuous in improvisoing, that sometimes he will not give way for the guitar.- $\Gamma$.

There are two tunes chiefly used in improverisoing; the Passo gallo, and the Folia di Sienna; the latter is so called because it is generally used in that eity, as the other is at Florence. The Passo gallo is more like reeitative than the Folia.- $V$.

The Count Torquata Montaiuti, of Arezzo, has translated upwards of forty of Ariosto's eantos, and has but two or three more to finish the whole. It is an exeellent translation; but doubtful whether he will ever publish it. He is one of the most modest men in the world.-Crnedeli.

Ariosto's poem is a continuation of Boiardo's Orlando Inamorato. He takes up the story just where Boiardo leaves off.- $C$.

\section{" Ed il guerrier, qui non s'en era accorto, Andava combattendo, ed era morto."}

This is a couplet of Berni's, in his burlesque of Boiardo"s poem. He laid that poem before him, generally used the very lines, and only ehanged some of them, to make the ridicule appear the stronger. $\uparrow$ - $C$.

* This was said in 1733.-Spence.

$\dagger$ Vedesti mai di due Palazzi, l'uno Vasto, ed immenso e con gran sale ed archi, Ed abbia più di quel, che in carte aduno? 
Ia Fontaine's Juconde is all taken from Ariosto; the part it is taken from is particularly well translated in the Latin version of Count Montaiuti.-C.

Menzini in his Poctica gives the truest illea of Ariosto, and 'Tasso, of any of our writers. "The poem of the former (says he) is like a vast palace, very riehly furnished. but built in detiance of the rules of architecture; whereas that of 'Tasso is like a neat palace, very regular and beattiful."*-Menzini's Poetice is very good, and so are his sonnets. In the latter, he is a consistent imitator of ('hiabrera, with more graee, but lesi of spirit and majesty.-C.

Muratori, an ceclesiastie of Modena, is one of the most learned men at present in Italy.-Manfredi of Bologna is a great mathematician; and the very best of all our [living] poets.-Metastasio, though much the best for operas, blames that way of writing. but shrugs up his shoulders, and says, " One must get money, you know."- - .

Redi"s Dithyrambic of Buceo in Toscana, is as lively and exeellent, as his sonnets are low and tasteless. $-C$.

Let a man excel as much as he please in anything else, he is not esteemed in Tuscany unless he ean write verses. This is the reason of Redi, and several others, being poets as well as philosophers.- $C$ '.

Filicaja, in his Sonnets, makes use of many expressions borrowed from the Psalms; and consequently not generally

Pur il tuo sguardo resteranne offeso Per qualche imperfezione; e tal vedrai O non finito, o non ben' anche inteso.

* Dore nell' altro in minor mole arrai Ordin più giusto, e rispondente al segno De' Latini Architetti, o pur del Graj. Mensini, Arte Poetica. Lib. ii. 
understood among us.-A gentleman of Florence, on reading some of the passages in him (which were taken literally from David), eried out, "Oh, are you there again with your Lombardisms!" and flung away the book as not worth the reading. $-C$.

Salvini was an odd sort of man; subject to gross absences: and a very great sloven. His behaviour in his last hours was as odd as any of his actions in all his lifetime before could have been. Just as he was departing, he eried out in a great passion, "I will not die! I will not die, that's flat." $-C$.

The author of the Circulus Pisanus is very strenuous for the modern system of the earth's moving round the sun; and says in that work: " that the world would certainly come into it hereafter ; and all unanimously ery out V. G." By which he meant Vicisti Galitcee!-The inquisitors did not understand the passage ; and took it for Verbi gratia, and so let it pass.- $C$.

The Greek statues are nine faces in height, and the Roman only eight.-Stosch.

Crescimbeni was continually inquiring, for twenty-eight years together, into the subject he has written upon (the History of Italian Poetry); and was much the ehief man in Italy for that sort of knowledge. His being a member of the Arcadi, and aequainted with all the poets in Italy of his time, must have given him great lights for all the latter parts of it. He had at first a very huddled method, but that is in a great measure remedied by the edition printed at Venice in 1730.-S.

There is a book of immense erudition, which is almost unknown: it is called La Crusca Provenzale e Catalana : 
in two volumes, in folio. It was written by a Spanish Abbé at Rome; and he proves in it, that the Tusean is absolutely derived from the old Catalan language. IIC left Rome soon after publishing it ; and earried almost all the eopies with him into Catalonia.-S.

I wonder how they eame not to find out printing sooner? (We had been just speaking of the mamer in which the emperors of Rome impressed their names with seals or stamps on their grants and letters.) This method was so common that the very shepherds impressed theirs* on their sheep and eattle. It was in faet a sort of printing, and it would have been as easy to impress a whole line as two words, and a page as a whole line. IIad they gone but these two easy steps farther, it would have been just what the Chinese printing is now.- $S$.

The aneient poets seem to use Laurus indifferently for the larger and the lesser laurels or bays. Strietly speaking, Lauro, or Lauro Regio, signifies the former in Italian ; and Alloro, the latter; but our poets too, use Lauro indifferently for both.-Crudeli.

We have garlands intermixed with fruits as well as

* Aut pecori signum, aut numeros impressit acerris.

Virg. Georg. i. 263.

Vivi quoque pondera melle?

Argenti coquito, lentumque bitumen aheno, Impressurus ovi tua nomina; nam tibi lites Auferet ingentes lectus possessor in arvo.

$$
\text { Calphurnins, Eslog. v. } 85 .
$$

The reader may see specimens of these Roman Sigill $a$, and some curious matter on the subject of ancient printing, in a work published a few years since, entitled, "Researches into the History of Playing Cards, Printing, and Engraving on Wood:" by the Editor of these Anecdotes. 
flowers; like that described by Virgil in his Eclogues.*$C$. [I afterwards saw some of these carried about the streets of Florence; the Sunday before Christmas Day. They were built up in a pyramid of evergreens, chiefly of bays; and faced with apples, grapes, and other fruits._-Spence.]

This old olive tree, that seems so totally dead in its trunk, and yet has such a flourishing young head, may serve to justify what Virgil has said $\uparrow$ in general of this sort of tree.-Crudeli.

[I believe they do this without the aid of art of them-. selves. The same is observable in our old willows, of which I have seen several (particularly in the garden island in St. James's Park), which send down a tap-root from their heads through the trunk, which often seems entirely deeayed; and so form a young tree on an old stock, which looks as flourishing as the other does rotten.-Spence.]

There is a place in the kingdom of Tunis, under the promontory of Mercury (now called Cape Bon), a few miles east of Carthage, that exactly answers Virgil's de-

Tibi candida Naïs

Pallentes violas et summa papavera carpens,

Narcissum, et florem jungit bene olentis anethi :

Tum casia atque aliis intexens suavibus herbis,

Mollia luteola pingit vaccinia caltha.

Ipse ego cana legam tenera lanugine mala,

Castaneasque nuces, mea quas Amaryllis amabat;

Addam cerea pruna; honos erit huic quoque pomo:

Et vos, o Lauri, carpam; et te, proxima myrte;

Sic positæ, quoniam suaves miscetis odores.

Virg. Eclog. ii. 46.

† Quin et caudicibus sectis, mirabile dictu, Truditur e sicco radix oleagina ligno.

Georg. ii. 30. 
seription of the Grotto, where Eneas anchored on his first coming to Afriea. This hollow goes in twenty or thirty fathoms, under the rock; and those who took out the stones from it, (for it seems to have been a quarry, left pillars, at proper distanees, to support the weight at top from falling in. T'he arches, whieh these pillars help to form, lie open to the sea : there are little streams perpetually draining from the roeks, and seats of stone formed within, probably for the use of those who worked in the quarry. There is a clift' on each side; and the brow of the mountain is overshadowed by trees.-Dir. Shaw, then at Florence, on his retum from his Travels.

Etruria aneiently had two kings: the seat of one of them was at Ceris, or Cervetere; and of the other, at Coitum, or Cortona. There were twelve chief eities in Etruria: the deputies from each of which met to elect these kings. Their establishment had an air of freedom.-Cuv. Venuti, a nobleman of Cortora.

In Fueas's time, Mezentius was the king at Cceris; and Tarehon, at Cortona. Hence Silius Italieus seems to comprehend all Etruria under the names of these two eities:

Lectos Ciere viros ; lecto Cortona superbi

Tarehontis domus__. $\dagger$

* Est in secessu longo locus. Insula portum Efficit objectu laterum; quibus omnis ab alto Frangitur, inque siuus scindit sese unda reductos. Hinc atque hine rastre rupes, geminique miuantur In cuelum scopuli; quorum sub vertice late Equora tuta silent : tum sylvis scena coruscis Desuper, horrentique atrum nemus imminet umbra. Fronte sub adversa, scopulis pendentibus antrum :

Intus, aque dulces; vivoque sedilia saxo. $\quad E n$. i. 159.

$\dagger$ Lib. viii. 474. 
Where, by the way, superbus seems to be used in a good sense, (as it often is in the Latin,* and several languages derived from it,) because Tarchon assisted in helping Fneas to the throne; and consequently toward the establishment of the Cæsars. This allianee of Eneas and Tarchon is pointed out by Virgil, so early as in the third book of the Aneid: where his great Gods tell him, " that Crete is not the place he is to fix at: no; he is to go on for Italy ${ }_{\uparrow}$ and Cortona."

The Ilex is what the Italians now call Ilce; that evergreen sort of oak, which has so dark a leaf; and which the old pocts so often mention together with the quercus or common oak.‡-Crudeli.

They found a vast piece of marble last summer at Rome, near the Forum Antoninii; which had been part of the architrave of that building. It was the only piece of antiquity I ever met with, that might serve to illustrate a passage in Vitruvius; where he is spcaking of a particular manner of disposing the roses on architraves.-Going to see it, I found the workmen very busy sawing it out, like common marble, to repair the arch of Constantine; and after all the remonstrance I could make to Galileo the arehitect, and others, there was only a rose or two, saved at last, and

* Populum late regem, belloque superbum.

En. i. 21. of the Trojans.

Virtute et factis animæ. Superbæ

Sil. Ital. x. 573.

† Corythum, terrasque require

Ausonias.

An. iii. 170.

† See Horace, Lib. iv. Od. iv. 58.-Epist. Lib. i. xvi. 10.Virgil's Georg. iii. 334 
sent into the eapitol.-Mr. Holdsworth (author of the Muscipula, then ut Rome.)

The areh of the bridge, built by Augustus at Nami, is a semicircle (as all the old Roman arches are); it measures one hundred and ten feet on the surface of the water.- $H$.

The ltalian noblemen have been so fond of getting the old Roman milestones to set before the entranee of their houses, and the collectors of antiquities are so wrong-headed, that between them, they have not left any two standing together, in their old places, all over Italy; to determine exactly low much the Roman mile was. The taking the first milestone from its proper spot to place it in the eapitol, has something of the same Gothieism or ignorance in it too. $-H$.

The three most celebrated triumphal arehes in Italy, are all either Trajan's, or ornamented from Trajan's.- $-H$. [He had been speaking of those at Aneona and Benevento, and that of Constantine at Rome.-Spence.]

The amphitheatre of Vespasian is raised four stories high ; and is adorned all round on the ontside with four different degrees of pillars; Doric, Ionic, Corinthian, and Composite. It is an oblong of eight huntred and twenty Roman palms, by seven hundred; and the height of it is two hundred and twenty-two. There were places in it for eighty-seven thousand persons. They formerly aseended by three steps to it; but they are now hid by the raising of the ground. There was no cement used in the whole building, but the stones are eramped together with lead and pieces of iron.- $H$.

They still use the method, so mueh recommended by Virgil, of burning the stubble, especially in the more barren fields, in most parts of Italy ; and about Rome in particular, 
where there is so much bad ground. The smoke is very troublesome when they do it, and there had been so many complaints marle of it, that Clement the Eleventh resolved to forbid the practice. When the order was lail before that pope to be signed by him, a eardinal (who happened to be with his holiness) spoke mueh of the use of it ; showed him the passage in Virgil : * and the pope on reading it changed his mind, and rejected the order.- $H$.

"Our religion is not founded upon reason," t said the Bishop of Arles, speaking of the religion of the church of Rome. That great prelate had the goodness to attempt (in a quarter of an hour's visit) to bring us over to the love of popery, and of a popish prince. When he found that we held steady to our principles all that time, he pitied us very much, and was extremely sorry that such fine and such promising young gentlemen would shut their eyes thus against the light, when it was offered to them: he lamented pathetieally over us, and begged us again to eonsider all that he had offered to us. If we did not, he said, it shoeked him to think of the sad consequence that could not but follow from our eontinuing in the way we were in: "for you Protestants (added he), when you die, all fall down into hell, as the flakes of snow fall upon the earth in the winter season." $\div$-Spence.

Malherbe was the first good poet among the French; and Rousseau is allowed by everybody to be their best now.

* Virg. Georg. i. 84-93.

† " Notre religion n'est pas fondée sur les raisonnements," were his words.-Mr. Spence has evidently mistaken the import of the word raisonnements-iditor.

$\ddagger$ "Quand vous venez à mourir, vous tomberez en enfer; comme les flocs de neige tombent sur la terre dans le tems de l'hyver." 
-Fontenelle has been the great corrupter of the French language; and the more from his writing with so much wit. Numbers endeavour to initate him, take the same liberties with the language, and aim at nothing but to shine.liamsay.

While Marshal Turenne was saying some very fine and very humane things, just after the battle of Retel; the Prince de Conde said: " What signifies moralizing so mueh about the matter, since one night at P'aris will make it all up again?"- $R$.

Pope and Boileau are certainly the two best poets of all the moderns. They both write extremely well; but I should prefer Pope to Boilean, beeause he excels in what is most material in the character of a poet. Boileau writes more correctly, and better than Pope; but Pope thinks more nobly, and has much more of the true spirit of poetry than Boileau.-R. [This had the more weight with me, beeause Dr. Cocehi, and other good judges I met with on the continent, agreed in this sentiment throughout, though they might express it in other words.] - Spence.

The Pretender's eldest son had been tanght, by his nurses, to be extremely terrified whenever it lightened. They had used to shut up all the winlows, and run into corners with him to avoid the sight of it. When Rimmsay was made his tutor, he resolved to take off so bad an impression. Whenever there was a storm, he would fling up the sashes, and hold him there, foreing him to fice the lightning. By this means, he in some time conquered his prejudices so far, that at last the boy came even to delight in looking at the lightning. He would run to the window, fling it up himself, and scemed to be diverted with the flashes 
instead of afraid of them. Somebody had told Cardinal Alberoni of this; and the next time he saw Ramsay, he complimented him upon it before a good deal of company. " You do well, M. Ramsay (said he), you must teach him to fear nothing; neither man, nor the devil, nor God himself-for, (added he, in a lower voice and graver air, on observing the company seemed shocked at what he had said) as to the good God, we ought to love him, not to fear him."*-From a firiend of Ramsay's.

* Vous faites très bien, Monsieur Ramsay. Il faut l'apprendre à ne rien eraindre; ni les hommes, ni le Diab!e, ni Dieu même. __ car-pour le bon Dieu-il faut l'aimer, et non pas lecruindre. 


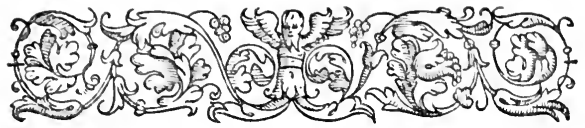

\title{
SPENCE'S ANECDOTES.
}

\author{
SECTION IV. 1734-36.
}

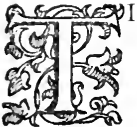

IE fanous Lord IIallifax (though so much talked of) was rather a pretender to taste, than really possessed of it.-When I had finished the two or three first hooks of my translation of the Ilial, that lord " desired to have the pleasure of hearing them read at his house."-Addison, Congreve, and Garth, were there at the reading.-In four or five places, Lord IIallifax stopped me very eivilly; and with a speceh, each time much of the same kind: "I beg your pardon, Mr. Pope, but there is something in that passage that does not quite please me.-Be so good as to mark the place, and consider it a little more at your leisure. -I am sure you ean give it a better turn."-I returned from Lord Hallifax's with Dr. Garth,* in his ehariot; and

* This is lengthened from the short hints in the first memorandum parer. Such fillings up, and in this particular, should be flung into notes; for one can't answer for the particular circumstances at such a distance of time.-For instance, according to my memory, it was Garth he returned home with; but in my paper, Congreve's name has a particular mark under it ; and so it might be he, and not Garth, that let Mr. Pope into this part of Lord Hallifax's character, This must be hinted at above, and enlarged upon in the notes. - Note in pencil on the margin by Spence. 
as we were going along, was saying to the doctor, that $\mathrm{my}$ lord had laid me under a good deal of diffieulty, by sueh loose and general observations; that I had been thinking over the passages alnost ever since, and could not guess at what it was that offended his lordship in either of them.-Garth laughed heartily at my embarrassment; said, I had not been long enough aequainted with Lord Hallifax, to know his way yet : that I need not puzzle myself in looking those places over and over when I got home. "All you need do (said he) is to leave them just as they are; call on Lord Hallifax two or three months hence, thank hin for his kind observations on those passages; and then read them to him as altered. I have known him much longer than you have, and will be answerable for the event."-I followed his advice; waited on Lord Hallifax some time after : said I hoped he would find his objections to those passages removed, read them to him exactly as they were at first; his lordship was extremely pleased with them, and eried out, "Ay now, Mr. Pope, they are perfectly right! nothing can be better." $-P$.

" Did not he write the Country Mouse with Mr. Pryor?", - " Yes, just as if I was in a chaise with Mr. Cheselden here, drawn by his fine horse, and should say,-Lord, how finely we draw this chaise!"-Lorel Peterborough.

Donne had no imagination, but as much wit, I think, as any writer ean possibly have.*_-Oldham is too rongh and coarse.-Rochester is the medium between him and the Earl of Dorset.-Lord Dorset is the best of all those writers.-What! better than Lord Rochester?'-Yes, Ro-

* It is remarkable that Dryden also says of Donne; " he was the greatest wit, though not the greatest poet of this nation." Jos. Warton. 
chester has neither so mueh delicacy or exactness as Lord Dorset.** $P$.

Sedley is a very insipid writer; except in some few of his little love-rerses. -2 .

"I have drawn in the plan for my Ethie Epistles mueh narrower than it was at first."- He mentioned sereral of the particulars, in which he had lessened it; but as this was in the year 1734, the most exact aceount of his plan (as it stood then) will best appear from a leaf which he ammexed to about a dozen copies of the prom, printed in that year, and sent as presents to some of his most partieular friends. Most of these were afterwards called in again; but that which was sent to Mr. Bethel was not. $\uparrow$ -

+ IIe instancel from Lord Rochester's Satire on Man.-Spence.

It run as follows,

\section{INDEX TO TIIE ETHIC EPISTLES.}

Book I. Of the Nature axd State of Man.

Epistle 1.-With respect to the Universe.

2.- As an Individual.

3.-With respect to Society.

4.-With respect to Happiness.

BоoK II. OF THE U'se of THINGs.

Of the Limits of IIuman Reason.

Of the Lse of Learning.

Of the Use of Wit.

- Of the linowleilge and Characters of Men.

Of the particular Characters of Women.

Of the Principles and Use of Civil and Ecelesiastical Polity.

Of the Use of Education.

A View of the Equality of IIappiness in the several Conditiuns of Men.

-Of the Use of Riches. 
You know there is nothing eertain about him (we had been speaking of Homer's blindness); that life, attributed to Herodotus, was hardly written by that historian, and all the rest have guessed out eireumstances for a life of him from lis own writings. I collected everything that was worth notice, and classed it; and then Arehdeacon Parnell wrote the Essay on his Life, which is prefixed to the Iliad.-It is still stiff; and was written much stiffer. As it is, I think verily it eost me more pains in the eorrecting, than the writing of it would lave done.*-P.

What Patereulus says of Homer's not being blind, might be said by him, only for the turn of it. Ilis book is a flimsy thing; and yet nine in ten that read it will be pleased with it. $-P$.

Parnell's? Pilgrim is very good.-The story was written

* Pope has heen blamed for his inconsistency in praising Parnell in one place and censuring him in another, but it should be remembered that Pope was no party to the publication of this censure, which was spoken in the confidence of conversation with a friend. The only eharges that can be made against him, are, his want of sincerity, and his propensity to feed the vanity of his correspondents by gross flattery. In a letter to Parnell, with whom he lived in habits of the strictest friendship, he says: "If I were to tell you the thing $I$ wish above all things, it is to see you again ; the next is to see your treatise of zilus, with the Batrachomnomachia and the Pervigilum Veneris, both which poems are master-pieces in their several kinds, and I question not the prose is as excellent in its sort as the Fssuy on Homer." -Dr. Anderson very justly observes, that " what he says in both places may be easily reconeiled to truth ; for everything of Parnell's that has appeared in prose, is written in a very awkward inelegant manner; but who can defend Pope's candour, and his sincerity ?"-Editor.

$\dagger$ In the first MS. memoranda of this conversation, Pope is made to say, that Parnell is " a great follower of drams; and strangely open and scandalous in his debaucheries."-As this was 
originally in spanish.-P. [Whenee, probably, Ilowel translated it, in prose, and inserted it in one of his letters.] -ipence.

It is a great fault, in deseriptive poetry, to deseribe everything. * The good ancients (bat when I named them, I meant Virgil) have no long deseriptions: commonly not above ten lines, and searee ever thirty. One of the longest in Virgil is when. Eneas is with Evander: and that is frequently broke by what Evander says.-P.

After reading the Persian Tales, (and I had been reading Iryden's Fables just before them, I had some thought of writing a Persian fable; in which I should have given a full loose to description and imagination. It would have

omitted in the transcript, Spence probably thought it not quite correct.-Poor Parnell did indeed give in to excesses after the deatl of his wife, whom he tenderly loved, and had the misfortune to lose in 1712 ; this event made such an impression on his spirits, that he could hardly bear to be alone, he sought therefore to obliterate his grief by company and conviviality; " those helps that sorrow tirst called in for assistanee, habit soon rendered necessary, and he died in his thirty-eighth year, in some measure a martyr to conjugal fidelity." Pope can hardly be suspected of having any motive to calumniate the man whom he had described in his Epistle to Lord Oxford, as " Just beheld and hist, admir'd and mourn'd!

With sweetest manners, gentlest arts adorn'l!"”

Whose company he seems to havebeen extremely fond of, and whose posthumous fame he had beeu particularly solicitons to increase! It is somewhat singnlar that this same charge of dram drinking has been bronght against the poet himself by Dr. King, in the late publication of "Aneclotes of his own time, p. 12." After relating an anecdote, which seems to give some colour to the charge, he says, in direct terms, that " Pupe hastened his death by feeding much on high-seasoned dishes, and drinking spirits.-Editor.

* That is the fault in Thomson's Seasons.-Addition from MS. 
been a very wild thing, if I had executed it; but might not have been unentertaining.*-P.

It might be a very pretty subject for any good genius that way, to write Ameriean pastorals; or rather pastorals adapted to the mamers of several of the ruder nations, as well as the Amerieans. I once had a thonght of writing such ; and talked it over with Gay : but other things eame in my way and took me off from it.-P.

If I am a good poet? (for in truth I do not know whether I am or not.) But if I should be a good poet, there is one thing I value myself upon, and which can searce be said of any of our good poets: and that is, " that I have never flattered any man, nor ever received anything of any man for my rerses." $-P$.

Dr. Swift was a great reader and admirer of Rabelais; and used sometimes to scold me for not liking him enough. Indeed there were so many things in his works, in which I could not see any manner of meaning driven at, that $I$ could never read him over with any patience. $-P$.

Lord Bolingbroke and the Bishop of Rochester (Atterbury) did not quite approve of 'Telemachus; and Lord

* In Pope's Letters to a Lady, published by Dudsley, in 1769, this thought is thus amplified: "I have long had an inclination to tell a fairy tale, the more wild and exotic the better; therefore a vision, wbich is confined to no rules of probability, will take in all the variety and luxuriancy of description you will; provided there be an apparent moral to it. I think one or two of the Persian tales would give one hints for such an invention : and perhaps if the scenes were taken from real places that are known, in order to compliment particular gardens and buildings of a fine taste, (as I believe several of Chaucer's descriptions do, though it is what nobody has ubserved,) it would add great beauty to the whole."Editor. 
Bolingbroke in partienlar used to say, that " he conld never bear the satfion Morning with her rosy fingers, in prose."-For my own part, though I don't like that poetic kind of prose writing, yet I always read Telemachus with pleasure.- " That must be, then, from the good sense and spirit of lmmanity that runs throngh the whole work?" Yes, it must be that; for nothing else could make me forget my prejudices against the style it is written in so much as $I$ do. $-P$.

The things that I have written fastest, have always pleased the most.-I wrote the Essay on ('riticism fast; for I had digested all the matter, in prose, before I began upon it in verse. The Rape of the Lock was written fast: all the machinery was alded afterwards; and the making that, and what was published before, hit so well together, is, I think, one of the greatest proofs of judgment of anything I ever dicl. I wrote most of the Iliad fast; a great deal of it on journeys, from the little pocket I Iomer on that shelf there; and often forty or fifty verses in a morning in bel.--The Dunciad cost me as much pains as anything I ever wrote.- $P$.

In the Moral Poem, I had written an address to our Savionr; imitated from Lueretius's compliment to Epicurus: but onitted it by the advice of Dean Berkley.--One of our priests, who are more narrow-minded than yours, made a less sensible objection to the Epistle on Happiness : he was very angry that there was nothing sail in it of our eternal happiness hereafter, though my sulject was expressly to treat only of the state of man here.- $P$.

The four first epistles are the seale for all the rest of the work, and were much the most difficult part of it.-I don't 
know whether I shall go on with the Epistles on Government and Education.- $P$. [He spoke a little warmer as to the use of it than before ;* but more coldly as to the execution.-Spence.]

I have omitted a character (though I thought it one of the best $\mathrm{I}$ had ever written) of a very great man who had everything from without to make him happy, and yet was very miserable; from the want of virtue in his own heart.$P$. [Though he did not say who this was, it seemed to have been that of the Duke of Marlborough.-He mentioned Julius Cæsar, and the late king of Sardinia, as instances of a like kind. $-S$.]

Count Osorio has given me two reasons for the king of Sardinia's quitting the crown. He said he thought it was either from his previous engagements and foresight of the war between France and the empire, or else from his beginning madness and apprehension that he should misbehave.-Pope.

Lord Bolingbroke will be more known to posterity as a writer and philosopher than as a statesman. He has several things by him that he will searce publish; and a good deal that he will.- P. [He at the same time spoke very highly of his Dissertation on the English History, and that on Parties: and called him " absolutely the best writer of the age."- $-\mathrm{He}$ mentioned then, and at several other times, how much (or rather how wholly) he himself was obliged to him for the thoughts and reasonings in his moral work ; and once in particular said, that beside their frequent talking orer that subject together, he had received, I think, seven or eight sheets from Lord Boling-

* See Sect. I. p. 12, ante. 
broke, in relation to it, as I apprehended by way of letter's; both to direet the plan in general, and to supply the matter for the particular epistles.*-Spence.]

He mentioned Cleveland and ('artwright as equally good, or rather equally bad.-What a noise was there made abont the superior merits of those two writers? - Donne is superior to Randolph ; and Sir W. Navenant a better poet than Donne. [He commended Monne's Epistles, Metempsychosis, and Sittires, as his best things. - S.]

All gardening is landseape painting.- $P$. [This was spoken as we were looking upon the round of the physic garden at Oxford; and the view through it, that looks so much like a picture hung up.]

Self-love would be a necessary principle in every one; if it were only to serve each, as a seale for his love to his neighbour. $-P$.

When there was so mueh talk about the Duke of Chandos being meant usder the eharaeter of Timon, Mr. Pope wrote a letter to that nobleman: (I suppose to point out some particulars which were incompratible with his character.) The Duke in his answer, sail, " He took the application that had been made of it, as a sign of the malice of the town against himself ;" and seemed very well satisfied that it was not meant for him. $-P$.

I wrote the law case of the black and white horses, with the help of a lawyer: (by what he added, it was the late Master of the Rolls, Fortescue.) - Dr. Arbuthot was the

- See also some very curious matter further confirming this disputed point, in Mr. D'Israeli's Quarrels of Authors, (vol. i. pp. $71 \cdot 3$,) a work replete with interesting anecdote, selected and arranged with infinite taste.-Editor. 
sole writer of Joln Bull; and so was Gay of the Beggar's Opera. I own appearances are against the latter; for it was written in the same honse with me and Dr. Swift. - He used to communieate the parts of it, as he wrote them, to ns ; but neither of us did any more than alter an expression here and there. $-P$.

Addison had Budgell, and, I think, Philips, in the house with him.-Gay, they would eall one of my Eleves. -They were angry with me for keeping so much with Dr. Swift, and some of the late ministry.*-Parnell was with me too, and had come over from the others, when Lord Oxford was at the head of affairs.-On Parnell's having been introduced into Lord Bolingbroke's company, and speaking afterward of the great pleasure he had in his conversation: Mr. Addison came out with his usual expression, "If he had but as good a heart as he has a head !" and applied to him, "that eanker'd Bolingbroke!" from Shakespeare. $-P$.

There had been a coldness between Mr. Addison and me for some time, and we had not been in company together, for a good while, anywhere but at Button's coffeehouse, where I used to see him almost every day.-On his meeting me there, one day in partieular, he took me aside, and said he should he glad to dine with me at such a tavern, if I would stay till those people (Budgell and Philipst) were gone. We went aceordingly, and after dimner Mr. Addison said, "that he had wanted for some time to talk with me: that his friend Tiekell, had formerly, whilst at

* Lord Bolingbrclie was one of my oldest acquaintances.-Addition from MS. $B$.

+ "He abused those two gentlemen very much, and saik, he hoped that noborly could think that he esteemed 'em heartily." MS. $B$. 
Oxford, translated the first book of the Iliad. That he now designed to print it : and had desired him to look it over: he must, therefore, leg that 1 would not desire him to look orer my first book, beeause, if he did, it would have the air of double dealing." - I assured him that I did not at all take it ill of Mr. Tickell, that he was going to publish his translation ; that he eertainly had as much right to translate any author as myxelf: and that publishing both, was entering on a fair stage."-I then added, " that I would not desire him to look orer my first book of the Iliad, beeanse he had looked over Mr. 'Tiekell's; but conld wish to have the benefit of his olservations on my seeond, which I had then finished, and which Mr. Tickell had not tonched npon." Aecordingly, I sent him the seeond book next morning: and in a few days he returned it with very high commendation.- Soon after it was generally known that Mr. Tickell was publishing the first book of the Hliad. I met Dr. Young in the street, and npon our falling into that subject. the doetor expressed a great deal of surprise at Tickell's having such a translation ly him so long. He said, that it was inconecivable to him; and that there must be some mistake in the matter: that he and Tiekell were so intimately aequainted at Oxford, that each used to commumicate to the other whatever verses they wrote, even to the least things: that Tickell conld not have been busied in so long a work there, withont his knowing something of the matter; and that he had never heard a single word of it, till on this oceasion. This surprise of Dr. Young, together with what Steele has said against 'Tickell in relation to this affair, make it highly probable that there was some underhand dealing in that business: and indeed Tiekell 
himself, who is a very fair worthy man, has since in a manner as good as owned it to me.-P. [When it was introduced in conversation between Mr. Tiekell and Mr. Pope, by a third person, Tickell did not deny it; which, considering his honour and zeal for his departed friend, was the same as owning it.*-Spence.]

Philips seemed to have been enconraged to abase me, in coffee-houses and conversations: Gildon wrote a thing about Wycherley, in whieh he had abused both me and my relations very grossly.-Lord Warwick $\uparrow$ himself told me, one day, " that it was in vain for me to endeavour to be well with Mr. Adlison; that his jealous temper would never admit of a settled friendship between us; and to convinee me of what he had said, assured me that Addison had encouraged Gildon to publish those scandals, and had given him ten guineas after they were published." The next day, while I was heated with what I had heard, I wrote a letter to Mr. Addison, to let him know " that I was not unacquainted with this behaviour of his; that if $I$ was to speak severely of him in return for it, it should not be in such a dirty way; that I should rather tell him himself fairly of his faults, and allow his good qualities; and that it should be something in the following namner." I then subjoined the first sketeh of what has been since called my satire on Addison.-He used me very eivilly ever after; and never did me any injustice, that I know of, from that time to his

- Lintott, in a letter to Pope, dated June 10, 1715, sending him Tickell's translation, says, "You have Mr. Tickell's book to divert one hour.-It is already condemned here, and the malice and juggle at Button's is the conversation of those who have spare moments from politics."-Editor.

† "Who was but a weak man himself."-MS. B. 
death, which was about three years after.-P. [Dr. Trapp, who was by at the time of this conversation, said that he wondered how so many people came to imagine that Mr. Pope did not write this eopy of rerses till after Addison's death: sinee so many people, and he himself for one, had seen it in Addison's lifetime.,Spence.]

A fortnight hefore Addison's death, Lord Warwick eame to Gay, and pressed him in a very partieular manner " to go and see Mr. Addison;" which he had not done for a great while. Gay went, and found Addison in a very weak way. IIe receired him in the kindest manner, and told him " that he had desired this risit to beg his pardon: that he had injured him greatly ; but that if he lived, he should find that he would make it up to him." Gay, on his going to Hanover, had great reason to hope for some good preferment;* but all his views eame to nothing. It is not impossible but that $\mathrm{Mr}$. Addison might prevent them, from his thinking Gay too well with some of the great men of the former ministry. He did not at all explain himself, in what he had injured him, and Gay could not guess at anything else, in which he could have injured him so eonsiderably. $-P$.

Wyehertey was really angry with me for correcting his rerses so much. I was extremely plagued, up and down, for almost two years with them. However, it went off pretty well at last; and it appears, by the edition of Wyeherley's Posthumous Works, that he had followed the adviee I so often gave him; and that he had gone so far as to make some hundreds of prose maxims out of his verses.Those verses that are published, are a mixture of Wyeher-

- The present family had made strong promises to him.-MS.B. 
ley's own original lines, with a great many of mine inserted here and there, (but not diffieult to be distinguished,) and some of Wyeherley's softened a little in the running, probably by Theobald, who had the chief care of that edition. - P.

Mr. Addison would never alter anything after a poen was once printed ; and was ready to alter almost everything that was found fault with before.-I believe he did not leave a word unchanged, that I made any scruple against in his Cato.*-P. [The last line in that tragedy originally.

"And oh, 'twas this that ended Cato's life."

It was Mr. Pope who suggested the alteration as it stands at present.

"And robs the guilty world of Cato's life."]-Spence.

'Tis amazing how Lord Peterborough keeps up his spirits, under so violent and painful an illness, as he is afflieted with. When I went down into Hampshire to see him, a few weeks ago, I did not get to him till the dusk of the evening; he was sitting on his eoueh, and entertaining all the company with as much life and sprightliness of conversation, as if he had been perfectly well: and, when the candles were brought in, I was amazed to see that he looked more like a ghost than a living ereature.-Dying as he was, he went from thenee to Bristol, and it was there that it was declared that he had no chance for a recovery, but by going through the torture of a very uncommon chirurgical

* A passage was objected to by Mrs. Oldfield, and Mr. Pope suggested the alteration to "stiffens yet alive."-" So the fair limpid stream, \&c."-tautology, a frequent fault of Addison: more such faults in lis Campaign than any one would easily imagine. $-P$. Addition from MS. $B$. 
operation; and that even with it, there were a great many more chanees against him than for him. However he would go through it; and the very day after set out from Bristol for Bath, in spite of all that st. Andre and the physicians could say to him." -1 . [ [t was some time after

* In a letter of Pope's to Martha Blount, dated August 25, 1735 , is the following very interesting account of a subsequent in. terview at Beris Momnt.-Editor.

"I found my Lord Peterborough on his coucl, where he gave me an aceount of the excessive sufferings he had passed through, with a weak voice, but spirited. He talked of mothing but the great amendunent of his condition, and of finishing the buildings and gardens for his best friend to enjoy after him; that he had one care more when be went to France, which was, to give a true account to posterity of some parts of history in Queen Anne's reign, which Burnet had scandalonsly represented; and of some others, to justify her against the imputation of intending to bring in the Pretender, which (to his knowledge) neither her ministers, Oxford and Bolingbroke, nor she, had any design to do. He next told me, he had ended his domestic affinirs, through such difficulties from the law, that gare him as much torment of mind, as his dis. temper hal done of body, to do right to the person to whom he had obligations beyond expression: that he had found it necessary not only to declare his marriage to his relations, but (since the person who hatd married them was deall) to re-marry lier in the chureh at Bristol, before witnesses The warmth with which he spoke on these subjects, made me think him much recorered, as well as his talking of his present state as a heaven to what was past. I lay in the next room to him, where I found he was awake, and called for help most hours of the night, sometimes crying out for pain. In the morning he got up at nine, and was carried into his garden in a chair: be fainted away twice there. He fell, about twelve, into a violent pang, which made his limls all shake, and his teeth chatter; and for some time he lay as cold as death. His wound was dressed, (which is done constantly four times a day,) and he grew gay, and sat at dinner with ten people. After this he was again in torment for a quarter of an hour; and as soon as the pang was over, was carried again into the garden to the 
this that I saw him at Kensington. I was admitted into his ruelle (for he kept his bed), and everybody thought he could not last above five or six days longer: and yet his first speeeh to me was, "Sir, you have travelled, and know the places; I an resolved to go abroad; which of the two would you think best for me to go to, Lisbon or Naples?" That very day he would rise to sit at dimer with us; and in a little time after actually went to Lisbon.-Spence.]

"A general is only a hangman in chief."-Lord Peterborough. [They had been just speaking of General Cadogan, and his father.]

"One morning when I went to hear Penn preach, for 'tis my way to be eivil to all religions." - Lord $P$.

workmen, talked of his history, and declaimed with great spirit against the meanness of the present great men and ministers, and the decay of publie spirit and honour. It is impossible to conceive how much his heart is above his condition : he is dying every other hour, and obstinate to do whaterer he has a mind to. He has concerted no measures beforehand for his journey, but to get a yacht in which he will set sail, but no place fixed on to reside at, nor has determined what place to land at, or provided any accommodation for his going on land. He talks of getting towards Lyons, but undoubtedly he can never travel but to the sea-shore. I pity the poor woman who is to share in all he suffers, and who can in no one thing persuade him to spare himself. I think he must be lost in this attempt, and attempt it he will.-He has with him, day after day, not only all his relations, but every creature of the town of Suuthampton that pleases. He lies on his couch, and receives them, thongh he says little. When his pains come, he desires them to walk out, but invites them to dine or sup, \&c. *****. Nothing can be more affeeting and melancholy to me than what I see here: yet he takes my visit so kindly, that I should have lost one great pleasure had I not come. I have nothing more to say, as I have nothing in my mind but this present object, which indeed is extraordinary. This man was never born to die like other men, any more than to live like them." 
"I would willingly live to give that raseal (Bunet) the lie in half his history."-Lord P. [ [He had marked both the volumes in several parts of the margin, and earried them with him to Lisbon.-Pope.]

" I took a trip onee with Penn to his colony of Pennsylvania. The laws there are contained in a small volume; and are so extremely good, that there has been no alteration wanted in any one of them, ever sinee Sir William made them.-They have no lawyers. Every one is to tell his own ease, or some friend for him : they have four persons, as juiges, on the beneh; and after the ease has been fully laid down, on both sides, all the four draw lots; and he on whom the lot falls deeides the question.-'Tis a fine eountry, and the people are neither oppressed by poor's-rates, tithes, nor taxes."-Lord $P$.

Under James the First, which was absolutely the worst reign we ever had, exeept perhaps that of James the Second.-Pope.

There is this difference, among others, between soft and sweet verses; that the former may be very effeminate, whereas the latter are not at all so. $-P$.

"Which, sir, do you look upon as our best age for poetry?"-Why, the last, I think; but now the old are all gone, and the young ones seem to have no emulation among them. $-P$.

When Atterbury was in the Tower, upon its being said in the drawing-room, "What shall we do with the man?" Lord Cadogan answered: "Fling him to the lions." The bishop was told of this: and soon after, in a letter to Mr. Pope, said, that he had fallen upon some verses in his room, which he must copy out for him to read. These were four 
extremely severe lines against Lord Cadogan: and in the last, in particular, lie called him

"A bold, bad, blundering, blustering, bloody booby."- $P$.

I never could speak in public: and I don't believe that if it was a set thing, I conld give an account of any story to twelve friends together, though I could tell it to any three of them, with a great deal of pleasure.- When I was to appear for the Bishop of Rochester, in his trial, thongh I had but ten words to say, and that on a plain point, (how that bishop spent his time whilst I was with him at Bromley,) I made two or three blunders in it: and that notwithstanding the first row of lords (which was all I could see) were mostly of my acquaintanee. $-P$.

The Bishop of Rochester's speech,* as it is juinted, could not be as he spoke it. I was there all the while. Both the bishop, and myself, minded the time; when he began, and when he left off. He was two hours in speaking it; and, as it is printed, you ean't well be above an hour reading it._-" Was not there an act of parliament read in the midst

* A copy of the bishop's speech was taken in short-hand (by order of the ministry) for the use of Mr. Wearg, one of the king's council, soon after made solicitor general, for his exertions on this occasion. It was printed by Woodward and Peele, from a copy sold them by Wearg's clerk!-Francklin had another short-hand copy, taken by a different person, which they were forced to buy off, and burnt the sheets. The two copies agreed rerbatim.Peele. Hoadly answered this speech of Atterbury's distinctly and fully, in several letters published in the London Journal, under the name of Britannicus. In the whole course of this dispute, the printed speech was always considered the right one; and was never denied to be so by the bishop or his friends.-All the letters in the London Journal about that time, signed Britannicus, were Hoadly's. $-1758 .-$ Spence. 
of it?"- $\mathrm{No}$, I don't remember that there was: but he was indulyed to sit down for two or three ninutes, to rest himself a little between the speaking.- $P$.

That very hot copy of verses against King William and Queen Hary, in this volume of the State Poens,* was written by the famois Mr. Manwaring: though he was so great a whig afterwards, on his aequaintance with Lord I Aallifax.-." Are not there several of Lord Dorset's pieces in these State Poems?" - Yes, I have met with two or three, in dipling about this volume already. $-P$.

Many people would like my Ode on Music better, if Dryden had not written on that subject. It was at the request of Mr. Steele that I wrote mine; $\uparrow$ and rot with any thonght of rivalling that great man, whose memory I do and always have reverenced. $-P$.

That pieture of Dr. Swift is very like him. Though his face has a look of dullness in it, he has very partieular eyes: they are quite azure as the heavens, and there's a very uncommon archess in them. $-P$.

When swift and I were onee in the country for some time together, I happened one day to be saying, "That if a man was to take notice of the reflections that came into his mind on a sudden as he was walking in the fields, or sauntering in his study, there might be several of them perhaps as good as his most deliberate thoughts."-On this hint, we both agreed to write down all the volunteer refleetions that should thus come into our heads, all the time we stayed there. We did so: and this was what afterwards

- Vol. iii. p. 319, Tarquin and Tullia.

† Steele's note, requesting his assistance, is dated July 26, 1711.-Editor. 
furnished out the maxims published in our miscellanies. Those at the end of one volume are mine; and those in the other Dr. Swift's. $-P$.

Dr. Swift had been observing once to Mr. Gay, what an odd pretty sort of thing a Newgate Pastoral might make. Gay was inelined to try at such a thing, for some time, but afterwards thought it would be better to write a comedy on the same plan. This was what gave rise to the Beggar's Opera. He began on it, and when first he mentioned it to Swift, the Doctor did not much like the project. As he carried it on, he showed what he wrote to both of us; and we now and then gave a correction, or a word or two of advice: but it was wholly of his own writing. When it was done, neither of us thought it would succeed. We showed it to Congreve, who, after reading it over, said, " It would either take greatly, or be damned confoundedly." -We were all at the first night of it, in great uncertainty of the event; till we were very much encouraged by overhearing the Duke of Argyle, who sat in the next box to us, say, "It will do,-it must do !-I see it in the eyes of them."-This was a good while before the first act was over, and so gave us ease soon; for the duke (bcsides his own good taste) has a more particular knack than any one now living, in diseovering the taste of the publie. Ile was quite right in this, as usual; the good nature of the audience appeared stronger and stronger every act, and ended in a clamour of applause. $-P$.

Gay was remarkable for an unwillingness to offend the great, by any of his writings : he had an uneommon timidity upon him, in relation to anything of that sort. And yet you see what ill luck he had that way, after all his care not to offend ! $-P$. 
"People have pitied you extremely, on reading your letters to Wycherley: surely "twas a very difficult thing for you to keep well with him?" - The most diftieult thing in the world.- - He lost his memory (forty years before he died) by a fever, and would repeat the same thought, sometimes in the compass of ten lines, and did not dream of its being inserted but just before: when you pointed it out to him, he would say, "Gauls-so, so it is! I thank you very mueh:- pray blot it out."- - He had the same single thoughts (which were very good) come into his head again, that he had used twenty years before. His memory did not earry above a sentence at a time. These single sentenees were good, but the whole was without eomexion; and good for nothing but to be flung into maxims.-_" In spite of his good sense, I eould never read his plays with true pleasure, from the general stiffness of the style!"- - $\mathrm{Ay}$, that was occasioned by his always studying for antitheses." $-P$.

The ehronology of Wycherley's plays I am well acquainted with, for he has told it me over and over. "Love in a Wood," he wrote when he was but nineteen; "The Gentleman Dancing-master," at twenty-one; "The Plain Dealer," at twenty-five: and "The Country Wife," at one or two and thirty. $-P$.

Dr. Swift has told me that he was born in the town of Leicester; and that his father was minister of a parish in Herefordshire.* $-P$.

- This appears singular; Pope probably misunderstood the dean, for it is pretty certain that he was born in Dublin. Pope, however, seems to have been convinced he was right, for in a letter to Swift he calls England his native country. Swift would often say, when he was provoked at the ingratitude of Ireland, "I am 
Addison used to speak often very slightingly of Budgell, " One that calls me cousin," __ " the man that stamped himself into my acquaintance, \&c."-P. [When Addison was first in town, in lodgings, Budgell lodged in the room over his. Ile walked much, and was troublesome to him. One night Addison was so tired of the noise that he invited him down to sup with him; and that began their acquaintance.-Spence.]

Inconsistent as the Duke of Marlborough's character may appear to you, yet, may it be accounted for, if you gauge his actions by his reigning passion, which was the love of money. He endeavoured, at the same time, to be well both at Hanover and at St. Germains; this surprised you a good deal when I first toll you of it; but the plain meaning of it was only this, that he wanted to secure the vast riches he had amassed together, whichever should succeed.-He was calm in the heat of battle; and when he was so near being taken prisoner (in his first campaign) in Flanders, he was quite unmored. It is true, he was like not of this vile country, I am an Englishman;" but, in cooler moments, he never denied that he was born in Dublin, and sometimes even pointed out the house in which he was born.-Pope has said his futher instead of his grandfather, in the latter part of this article.-Editor.

* There must be some inaccuracy in this story, for poor Budgell was in fact a cousin of Addison's, and appears to have been very early in life patronized by him. When Addison was made secretary to Lord Wharton, in 1710, he appointed Budgell his clerk. His papers in the Spectator are marked $\mathrm{X}$. and those by him in the Guardian are distinguished by an asterisk. - His melancholy end was accelerated by distressed circumstances, brought on by repeated acts of indiscretion; he drowned himself by springing from a boat into the Thames, his pockets being filled with stones, in the year 1737.-Editor. 
to lose his life in the one, and his liberty in the other; lut there was none of his money at stake in either.-This mean passion of that great man, operated very strongly in him in the very beginning of his life, and eontinued to the very end of it.-One day, as he was looking orer some papers in his serutoire with Lord Cadogan, he opened one of the little drawers, took out a green purse, and turned some broal piees out of it. Ifter riewing them for some time, with a satisfaction that appreared rery visibly on his face; "Cadogan (said he), observe these pieces well ! they deserve to be observed; there are just forty of them: 'tis the very first sum I ever got in my life, and I have kept it always unbroken, from that time to this day." This shows how early, and how strongly, this passion must have been upon him; as another little affiir, which happened in his last deeline, at Bath, may serve (among many others) to show how miserably it continued to the end. He was playing there with Dean Jones at piquet, for sixpence a game; they played a good while, and the Duke left off when wimer of one game. Some time after, he desired the Dean to pay him his sixpence, the Dean said he had no silver; the Duke asked him for it over and over, and at last desired that he would ehange a guinea to pay it him, beeause he should want it to pay the chair that earried him home.-The Dean, after so much pressing, did at last get ehange; paid the Duke his sixpence; observed him a little after leave the room, and declares, that (after all the bustle that had been made for his sixpence) the Duke actually walked home to save the little expense a chair would have put him to.- $P$.

Lord Cadogan appeared shamefully at the Duke of Marlborough's funeral. He showed his pleasure in his 
face, and in his actions. All his behaviour on that oceasion looked more like an exultation that he himself was going to be chief, than an attendanee of that man to his grave, who had been the entire making of him.-P.

"I was extremely inclined to have gone to Lisbon with Lord Peterborough."-_" That might lave done you good indeed, as to your health; but it must have been a very melancholy thing for you to be so entirely (as you would have been) with a person in his condition."- " That's true: but if you consider how I should have been employed all the time, in vursing and attending a sick friend, that thought would have made it agreeable." $-P$.

The witty Duke of Buckingham was an extreme bad man. His duel with Lord Shrewsbury was concerted between him and Lady Shrewsbury. All that morning she was trembling for her gallant, and wishing the death of her husband; and, after his fall, 'tis said the duke slept with her in his bloody shirt.-P.

You know I love short inseriptions, and that may be the reason why I like the epitaph on the Count of Mirandula* so well.- Some time ago I made a parody of it for a man of very opposite character-

Here lies Lord Coningsby; be civil,

The rest God knows, perhaps the devil.-Pope.

I paid Sir Godfrey Kneller a visit but two days before he died $; \uparrow$ I think I never saw a scene of so much vanity

* Johannes jacet hic Mirandola : cæetera norunt Et Tagus, et Ganges, forsan et Antipodes.

† It was upon this occasion the following conversation is said to have occurred; the authority for it, is the younger Richardson. -Mr. Pope was sitting by Sir Godfrey's bedside, and seeing him 
in my life. He was lying in his hed, and eontemplating the plan he had male for his own monument. He said many gross things in relation to himself, and the memory he shonld leave behind him. Ite said he should not like to lic among the rascals at Westminster; a memorial there would be sufticient; and desired me to write an epitaph for it. I did so afterwards; and I think it is the worst thing I ever wrote in my life. $-P$.

" Did you never hear Sir Golfrey's dream?"- " No." - "Why then I'll tell it you.-A night or two ago (said Sir Godfrey) I had a very odd sort of dream. I dreamt that I was dead, and soon after found myself walking in a narrow path that led up between two hills, rising pretty equally on each side of it. Before me I saw a door, and a great number of people abont it. I walked on toward them.-As I drew nearer, I could distinguish St. Peter by his keys, with some other of the apostles; they were admitting the people as they eame next the door. When I had joined the company, I could see several seats, every way, at a little distance within the door. As the first, after my coming up, approaehed for admittanee, St. Peter asked his name, and then his religion.-I am a Roman Catholic, replied the spirit. Go in then, says St. Peter, and sit down on those seats there on the right hand. The next was a Presbyterian: he was admitted too after the usual questions, and ordered to sit down on the seats opposite to the other. My turn came next, and as I approached, St. Peter very

so impatient at the thoughts of going, had told him, he had been a very good man, and no duibt would go to a better place :- " $\mathrm{Ah}$, my good friend, Mr. Pope (said he), I wish God would let me stay at Whitton."-Editor. 
civilly asked me my name. I said it was Kneller. I had no sooner said so, than St. Luke (who was standing just by) turned toward me, and said, with a great deal of sweetness-' What! the famous Sir Godfrey Kneller, from England?'- The very same, sir, (says I,) at your service.'-On this St. Luke immediately drew near to me, embraced me, and made me a great many compliments on the art we had both of us followed in this world: He entered so far into the subject, that he seemed almost to have forgot the business for which I eame thither. At last, however, he recolleeted himself, and said; ' I beg your pardon, Sir Godfrey; I was so taken up with the pleasure of conversing with you !-But, apropos, pray, sir, what religion may you be of?'- 'Why truly, sir, (says I,) I am of no religion.' - $O$, sir, (says he,) you will be so good then as to go in and take your seat where you please." $-P$.

My letter to Mr. Addison on a Future State, was designed as an imitation of the style of the Spectators; and there are several eant phrases of the Speetator in it. $-P$. [As " Seale of beings," and some others which he mentioned.]

$\mathrm{My}$ letters to Cromwell were written with a design that does not generally appear; they were not written in sober sadness. $-P$.

The piece to prove that all learning was derived from the Monkeys in Elhiopia, was written by me, and (I think he added) Dr. Arbuthnot. It made part of the Memoirs of Seriblerus. The design of it was to ridieule such as build general assertions upon two or three loose quotations from the ancients. $-P$.

There is nothing more foolish than to pretend to be sure 
of knowing a great writer by his style.-P. [Mr. Pope seemed fond of this opinion. I have heard him mention it several times, and he has printed it as well as said it. But, I suppose, he must speak of witers when they use a borrowed style, and not when they write their own. He himself had the greatest eompass, in imitating styles, that I ever knew in any man: and he hard it partly from his methorl of instructing himself, after he was out of the hands of his bal masters, which was, at first, almost wholly by imitation. Mr. Addison did not discover Mr. Pope's style, in the letter on Pastorals, which he published in the Guardian; but then that was a disguised style. Mr. Pope had certainly a style of his own, which was very distinguishable. Mr. Browne, in his imitations of the styles of several different sorts of poets, has pointed it out strongly; and ifr. Pope used to speak of those likenesses as very just and very well taken. It is much the same in writing as in painting; a painter (who has a good manner of his own, and a good talent for copying), may quite drop his own manner in his copies, and yet be very easy to be distinguished in his originals._Spence.]

Lord Bolingbroke wrote the long inseription, on the column set up in honour of the Duke of Marlborough, at B!enheim.-- " I own I should have thought that too stiff for so fine and easy a writer as Lord Bolingbroke?" "What may scen too stiff to you in it, is from that Lord's imitating the best old inseription style on that oecasion." $-P$.

Lord Bolingloroke is something superior to anything I have seen in human nature. You know I don't deal much in hyperboles: I quite think him what I say.-P.

Lord Bolingbroke is much the best writer of the age.- 
Nobody knows half the extent of his excelleneies, but two or three of his most intimate friends.-Whilst abroad, he wrote, "A consolation to a man in exile;" so much in Seneca's style, that, was he living now among us, one should conclude that he had written every word of it. He also wrote several strictures on the Roman affairs (something like what Montesquieu published afterwards) among which there were many excellent observations. $-P$.

Lord Bacon was the greatest genius that England (or perhaps any country) ever produced.- $P$.

One misfortune of extraordinary geniuses is, that their very friends are more apt to admire than love them. $-P$.

When a man is much above the rank of men, who can he have to converse with ?-P. [He had been speaking of Lord Bacon, and Lord Bolingbroke, a little before: this reflection seems to have arisen in his mind, in relation to one, or, perhaps, both of them.-Spence.]

I was born in the year 1685.-My Essay on Criticism was written in 1709 ; and published in 1711 ; which is as little time as ever I let anything of mine lay by me.-P.

Sir William Davenant's Gondibert is not a good poem, if you take it in the whole; but there are a great many good things in it.-He is a scholar of Donne's, and took his sententiousness and metaphysies from him.- $P$.

The burlesque prologue to one of Sir William Davenant's plays leegan with this couplet:

"You who stand sitting still to hear our play, Which we to-night present you here to-day." $-P$.

I don't think Dryden so bad a dramatic writer as you seem to do. There are as many things finely said in his 
plays, as nlmost by anybody. Beside his three best, (All for Love, Don Sebastian, and the Spanish Eryar,) there are others that are good: as, Sir Martin Mar-all, Limberham, and The Conquest of Mexieo. Mis Wild Gallant was written while le was a boy, and is very bad.-. Ill his plays are printed in the order they were written.- $P$ ".

1) ryden, in his " Spanish Fryar," speaking of the bad titles of kings growing good by time, had said,

"So when clay's buried for a hundred years, It starts furth china."

Betterton found fault with it, as mean, and Dryden omitted it.-Dr. Tropp, from Betterton.

It is easy to mark out the general course of our poetry. Chaneer, Spenser, Milton, and Dryden, are the great landmanks for it. $-P$. [It is plain that he was speaking of our miscellancous writers, by his omitting Shakespeare, and other considerable names in the dramatie way. His own name, added to the four he mentioned, would complete the series of our great poets in general.-Spence.]

It was King Charles the Second who gave Dryden the hint for writing his poem called "The Medal." One day, as the king was walking in the Mall, and talking with Dryden, he said, " If I was a poet, and I think I am poor enough to be one, I would write a poem on such a subject, in the following manner:" and then gave him the plan for it.-Dryden took the hint, earried the poem as soon as it was finished to the king, and had a present of a hundred broad pieees for it.-[This was said by a priest that I often met at Mr. Pope's: and he seemed to confirm it; adding, that King Charles obliged Dryden to put his Oxford speech 
into verse, and to insert it toward the close of his Absalom and Achitophel.-Spence.]

When the same priest was saying, that in the disputes between the Catholics and Protestants in James the Second's reign, their cause had not so gool hands to defend it as it deserved.-Mr. Pope said, "Sir, I beg your pardon, we had really some very clever men, engaged on our side, as well as some very wretched ones." - [He mentioned Whitehead;-a piece called Pax Vobis; another called Fiat Lux; and some other persons and pieces, the names of which I have forgot.-Spence.]

Chaucer and his contemporaries borrowed a good deal from the Provençal poets : the best account of whom, in our language, is in Rymer's piece on Tragedy.- " Rymer a learned and strict eritic?"-_ Ay, that's exactly his eharacter. He is generally right, though rather too severe in his opinion of the particular plays he speaks of; and is, on the whole, one of the best critics we ever had." - $P$.

Skelton's poems are all low, and bad: there's nothing in them that's worth reading.- $P$. [Mr. Cleland, who was by, added, that the Tunning of Ellinor Rummin, in that author's works, was taken from a poem of Lorenzo de' Medici's._Spence.]

Cowley is a fine poet, in spite of all his faults.-He, as well as Davenant, borrowed his metaphysical style from Donne._- Sprat a worse Cowley.-P.

Ćrecch lurt his translation of Lucretius very much, by imitating Cowley, and bringing in turns [of expression], even into some of the most grand parts. He has done more justice to Manilius than he has to Lucretius.- " That was 
much easier to do?"- "That's true."-“ No, he could never be of the high age," (spenking of Manilius.) - $P$.

Shakespreare generally used to stiffen his style with high words and metaphors for the speeches of his kings and great men: he mistook it for a mark of greatness.-This is strongest in lis early plays; but in his very last, his Othello, what a foreed language has he put into the mouth of the Duke of Venice? ${ }^{*}-$ This was the way of Chapman, Massinger, and all the tragie writers of those days.-[It was mighty simple in Rowe, to write a play now, professedly in Shakespeare's style, that is, professedly in the style of a bad age.] $-P . \dagger$

Milton's style, in his Paradise Lost, is not natural; 'tis an exotic style.-As his subjeet lies a good deal out of our world, it has a partieular propriety in those parts of the poem: and, when he is on earth, wherever he is describing our parents in Paradise, you see he uses a more easy and natural way of writing.-Though his formal style may fit the higher parts of his own poem, it does very ill for others who write on natural and pastoral subjects. Philips, in his Cyder, has sueceeded extremely well in his imitation of it, but was quite wrong in endeavouring to imitate it on such a subject. $-P$.

* Dr. Young observed to me, that Shakespeare's style, where the hearts and manners of men was the subject, is always good; his bad lines, generally, where they are not concerned. 1759.Spence: from MS. B.

† Mr. Spence, in a note, says of this paragraph, " Omitted in vellum Copy," i. e. I prestme, in the MS. now in the Duke of Newcastle's library. It would have been as well for Pope's reputation as a critic if it had never been recorded.-Editor. 
Lord Bathurst used to call Prior his verseman, and Lewis his proseman.--Prior, indeed, was nothing out of verse: and was less fit for business than even Addison, though he piqued himself much upon his talents for it.-What a simple thing was it to say upon his tombstone, that he was writing a history of his own times :- He could not write in a style fit for history; and, I dare say, he never had set down a word toward any such thing.- $P$.*

Mr. Addison could not give out a common order in writing, from his endeavouring always to word it too finely. †He had too beautiful an imagination to make a man of business. $-P$.

Sir Isaac Newton, though so deep in Algebra and Fluxions, could not readily make up a common account : and, when he was Master of the Mint, used to get somebody to make up his accounts for him.- $P$.

Milton was a great master of the Italian Poets; and I have been told, that what he himself wrote in Italian is in exceeding good Italian.-I can't think that he ever meant to make a tragedy of his Fall of Man. At least I have Andreini's Adamo ; and don't find that he has taken anything from it. $-P$.

In Queen Elizabeth's time, and a great deal lower, people went from hence to Italy for manners, as they do now

* In this Mr. Pope was mistaken, for this history of his own times was subsequently given to the world: it is indeed poorly written enough.-Editor.

† Confirmed by Dr. L-'s Account of Russel.-Lord Oxforả said, one day before Mr. Sandys (son to Lord Sandys), "This fellow can't write a common letter," and snatched the pen out of Addison's hand, and wrote it himself.-Spence, from pencil note in MS. B. 
to France. Ascham has a severe letter upon it; and there are many passages relating to it in shakespeare, and sereral other of our old dramatie writers. - $P$.

The Profoneme, though written in so ludierous a way. may be very well worth reading seriously, as an art of rhetorie.-P.

I have so much of the materials for the Nemoirs of Serillerus ready, that I could eomplete the first part in three or four days. $-P$.

It is idle to say that letters should be written in an easy familiar style: that, like most other general rules, will not hold. The style, in letters as in all other things, should be adapted to the subject.-Many of Voiture's letters on gay subjects, are excellent; and so are Cicero's, and several of Pliny's and Seneea's, on serious subjeets.-I do not think so ill even of Balzae, as you seem to do ; there are certainly a great many good things in his letters, though he is too apt to run into affectation and bombast.-The Bishop of Roehester's letter is on a grave subject (on the Value of Time), and therefore should be grave.-P. [On my having said that a friend of mine thought that letter of the Bishop's too stiff.-Spence.]

I began translating the Iliad in my twenty-fifth year, $(1712$, ) and it took up that, and five years more, to finish it.-Mr. Dryden, though they always talk of his being hurried so much, was as long in translating Virgil: but, indeed, he wrote plays and other things in the same period.* $-P$.

* Mr. Malone observes on this passage, "It is strange that this great poet, who lived so near the time, shonld have been so inac. eurate in his aceount of his predecessor's performance; for during the period in which this translation was made, Dryden eertainly 
Hutcheson is a very odd man, and a very bad writer: but he has struck out very great lights, and made very considerable discoveries by the way: as I have heard from people who know ten times more of those matters than I do.—“ Does Lord Bolingbroke understand Hebrew?"No, but he understands that sort of learning, and what is wrote about it. $-P$.

Lord Oxford was huddled in his thoughts, and obscure in his manner of delivering them.-It was he who advised Rowe to learn Spanish ; and after all his pains and expectations, only said; "Then, Sir, I envy you the pleasure of reading Don Quixote in the original."- W Was not that cruel?"- " I don't believe it was meant so ; it was more like his odd way." $-P$.

The works of Pindar that remain to us, are by no means equal to his great character.-His Dithyrambics, which were his best things, are lost; and all that is left of his works being on the same subject, is the more apt to be tiresome.-This is what induced me to desire Mr. West not to translate the whole, but only to choose out some of them. $-P$.

Monsieur St. Evremond would talk for ever. He was a wrote not a single play; and the work, instead of consuming six years, employed but half that time. It appears to have been begun in the summer of 1694 - was probahly sent to the press in the beginning of 1697 ; and published in the following July —. It is painful to learn, frum Dryden's letter to 'Tonson, that he would have made the annotations on this work much more ample, but that the bookseller would not make him any compensation for them. "I am sorry (says he), that you would not allow any thing towards the notes; for to make them good, would have cost half a year's time at least......It would require seven years to translate Virgil exactly."-Lije of Dryden, p. 234. 
great epieure, and as great a sloven. He lived, you know, to a great old age, and in the latter part of his life, used to be always feeding his dueks; or the fowls that he kept in his chamber. He had a great variety of these, and other sorts of animals, all over his house. Ile used always to say, "that when we grow old, and our own spirits deeay, it reanimates one, to have a number of living ereatures about one, and to be much with them." $-P$.

The French translation of my Essay on Man, gives the sense very well, and lays it more open: which may be of good service to Mr. Dolson in any passages where he may find himself obliged to enlarge a little. $-P$. [A bout this time (1736), Lord Oxford was very desirous of having the Essay on Man translated into Latin verse. Mr. Iobson had got a great deal of reputation by his translation of Pryor's Solomon.-On my mentioning something of the diffieulties which would attend the translation of his essay, Mr. Pope said, " If any man living could do it Dobson could." And by his desire I engaged that gentleman to undertake it. Lord Oxford was to give him a hundred guineas for it. He began upon it, and I think translated all the first epistle: what I showed of it to Lord Oxford and Mr. Pope was very well approved of.-It was then that Mr. Benson offered to give the same gentleman a thousand pounds, if he would translate Milton's Paradise Lost. He told me of that offer, as inelined to elose with it if he conld; and on my mentioning it to Lord Oxford and Mr.. Pope, they readily released him from his first engagement, and so left him at full liberty to enter upon the other.-Spence.]

As I was sitting by Sir Godfrey Kneller one day, whilst he was drawing a pieture, he stopped and said, "I can't 
do so well as I should do, unless yon flatter me a little, pray flatter me, Mr. Pope ! you know I love to be flattered." -I was once willing to try how far his vanity would carry him: and after considering a picture which he had jnst finished, for a good while, very attentively; I said to him in French (for he had been talking for some time before in that language), " On lit dans les Ecritures Saintes, que le bon Dieu faisoit l'homme après son inage: mais, je crois, que s’il voudroit faire un autre à présent, qu’il le feroit après l'image que voilà." - Sir Godfrey turned round, and said very gravely,-“" Vous avez raison, Mons. Pope; par Dieu, je le crois aussi." "*-P.

* The following anecdotes of Sir Godfrey Kneller, scome of which were derived also from Pope, are related by the younger Richardson, and were given to the world in a posthumous publication, but little known,'entitled, " Richardsoniana ; or, Occasional Reflections on the Moral Nature of Man, 8vo. 1776," they are too characteristic and curious to be omitted here.-Editor.

Gay read a copy of verses he had made on Sir Godfrey Kneller, to him, in which he had pushed his flattery so far, that he was all the while in great apprehension that Sir Godfrey would think himself bantered. When he had heard them through, he said, in his foreign style and accent : " $\mathrm{Ay}, \mathrm{Mr}$. Gay, all what you have said is very fine, and very true; but you have forgot one thing, my good friend, by G-, I should have been a general of an army; for when I was at Venice, there was a Girandole, and all the Place St. Mark was in a smoke of gunpowder, and I did like the smell, Mr. Gay; I should have been a great general, Mr. Gay!"

"By G-, I love you, Mr. Cock, (said Sir Godfrey Kneller to Cock the auctioneer,) and I will do you good; but you must do something for me too, Mr. Cock; one hand can wash the face, but two hands wash one another."-Pope.

Old Jacob Tonson got a great many fine pictures, and two of himself, from him, by this means. Sir Godfrey was very covetous, but then he was very vain, and a great glutton; so he played these passions against the other; besides telling him he was the greatest 
master that ever was, sending him, every now and then, a haum h of venison, and dozens of excellent claret.- 0 , my (i-, man, (said he once to Vander Gutcht,) this old Jneob loves ne; he is a very good man; you see he loves me, he sends me gont things; the venison was fat."-Old Geekie, the surgeon, got several fine pictures of him too, and an excellent one of himself; but then he had them eheaper, for he gave nothing but praises; but then his praises were as fat as Jaeob's venison; neitler could be too fat for Sir Gollirey.-Pope.

Secretary Craggs brouglit Dick Esteourt onee to Sir Godfrey Kneller's, where he mimicked several persons whom he knew; as Lords Godolphin, Somers, Hallifax, \&e. Sir Godfrey was highly delighted, took the joke, and langhed heartily : then they gave him the wink, and he mimieked Nir Golfrey himself; who cried, "Nay, now you are ont, man ; by G-, that is not me." 


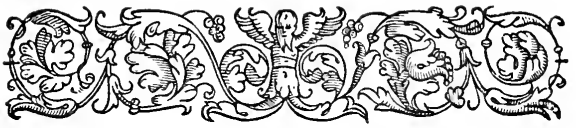

SPENCE'S ANECDOTES.

SECTION V.* 1737-39.

Sollection of pietures in the Palais Royal at Paris, cost the Regent above a million of Louis d'ors. In particular the St. Joseph, little Jesus, and Virgin, cost fifteen thousand livres (or six hundred and twenty-five guineas), the little St. John, Jesus, and Virgin, thirty thousand livres; and the St. John in the Wilderness, fifty thousand livres.-The pieture of a Muleteer, in that collection, was painted by Correggio, and served for a good while as a sign to a little public-house by the road side. It has still the marks in the upper corners of its having been doubled in for that purpose. The man who kept the house had been a muleteer, and had on some oceasion obliged Correggio a good deal, on the road. He set him up, and painted his sign for him. The persons who were sent into

* The fifth and sixth centuries (or sections), of these Anecdotes, according to Mr. Spence's division, are here blended into one; because it has been deemed proper to omit all those observations on Virgil by Mr. Holdsworth, which were printed in Warton's Virgil, or in the publication of Mr. Spence from Mr. Holdsworth's papers ; and a few other articles on very unimportant or uninteresting subjects.-Editor. 
Italy to colleet pietures for the Regent, met with this sign, and bought it. It eost five hundred guineas.-This gallery was painted by (the best) Coypel. "Surely it is hardly worthy of him." - That is beeause it has bad neighbours. It might do very well in any other palace in Paris, but must look poor and unaffecting to you, after having passed through the other rooms.-." But I think those pietures on the roof are much better than these on the walls?"-That's very true: Coypel painted the roof first, and between the painting of the ceiling and the sides, he took to dram-drinking, which soon spoiled his hand: and so mueh the sooner, beeause he had previously been a water-drinker. The Officer who showed us the Pulace.

[At the Count of 'Toulouse's gallery, the oftieer said, " My Lord is the best of masters ; lout alas! he grows very old, and, I fear, ean't last long: I would with all my heart, give ten years out of my own life to prolong lis, if it eould be done."- Upon seeing us affected by what he had said ; he added: " that this was no great merit in lim ; that most of his fellow-servants, he believed, would be willing to do the same: that the goodness of their master to them, and the greatness of tlieir affection for him, was so remarkable and so well known, that a friend of the Count's onee said to him; 'I don't know what it is you do to charm all the people thus about you; but though you have two hundred servants, I believe there is searee any one of them that would not die to save your life.'- 'That may be, (replied the Count,) but I would not have any one of them die, to save it.' ']

Mr. Addison stayed above a year at Blois.-He would rise as early as between two and three in the height of 
summer, and lie a bed till between eleven and twelve in the depth of winter.--He was untalkative whilst here, and often thoughtful: sometimes so lost in thought, that I have come into his room and stayed five minutes there, before he has known anything of it.-He had his masters, generally, at supper with him ; kept very little company beside; and had no amour whilst here, that I know of; and I think I should have known it, if he had had any.*_-Abbé Philippeaux, of Blois.

"We have two millions of religious, (men and women of all sorts,) and only twenty millions of souls in France :" said a sensible priest of the order of St. Geneviève at Blois. -I said our computation was about two hundred thousand ecclesiastics for France.- He laughed at that, as extremely short of their numbers; and, by his computation, made it one tenth part of the whole population, instead of one hundredth only.-Whereas our clergy in England, is but one four hundredth part of the people, computing the people at eight millions. How much would it tend toward the enslaving and impoverishing the country, should we ever happen to have a Popish prince, and grow as zealous $\mathrm{Ca}$ tholics as they are in France?-Spence.

Father Courayer was the most amiable man, and was, in fact, the most generally beloved of anyone I know in our order. - I have heard the Abbé Bignon, (who is as good a judge of writing as any man living,) say " that lie looked on

* [The strange story that the Abbé Morei told, as the cause of the redness in his cheeks:- a blow from an invisible hand, in an old castle in Normandy.-Spence. This hint follows the above article in the MS. B. so often referred to, whether it relates to Addison or not, does not appear. I have not heen fortunate enough $t_{0}$ meet with the original memorandum paper.-Editor. 
Courayer as the best pen in France."-Courayer is, as Father Paul was before him, a (atholie by profession, but a Protestant in his partienlar tenets.*-The same Priest.

Roussean is now grown old: he was, for a long time, onr only poet: now Voltaire may share that honour with hin ; and is next to him both in merit and reputation.-Abbé Boileau, at Tours.

Corneille's middle plays (for you know they are published in the order in which they were written), are his only good ones. Ite has a greater variety of characters, and those more distinguished than Raeine's. One should set his good plays only against those of the latter, which are in all but six; and Corneille has nine or ten good ones.-Abbé $B$.

The sprectators, though there are so many bad ones among them, make themselves read still. All Addison's are allowed to be good, and many of Steele's.-Gulliver was reeeived but indifferently, at first, among us; but pleased mueh after people had entered more into the humour of it.-Ablé $B$.

Ramsay wrote his Cyrus in imitation of Fenelon, and perhaps had some papers of his to help him in that work. That got him some reputation; but it is fallen again by the publishing of his Turenne. Everybody is angry with him for that history, beeause Turenne's is a favourite charaeter among us; and everylody eomplains that he has not written up to the dignity of his subjeet.-The Commentaries of Turenne are much better written, and have a good deal of Julius Cæsar's manner in them.-Abbé B.

" His words were, " Paolo est, comme lui, Catholique en gros et Protestant en détail." 
Old Fontenelle has done a great deal of hurt to our language.-Abbé B. [I have often heard Ramsay complain of the same. He used to say that he was the ehief corrupter of the Freneh language, by introducing so many new words and expressions; and writing with so much wit :numbers endeavour to initate him, take the same liberties, and aim at nothing but to shine. Partieular instances of his faults, and those of his imitators, are pointed out in the Memoirs of the Calotte.-Spence.]

Mons. Le Sage writes for bread. He has published Gusman d'Alfarache, and always keeps to Spanish seenes. -_ Has he ever been in that eountry?"--Yes, I think, he has.-He is a very worthy good man, and cheerful though so extremely deaf; and even gay in company, by the help of a cornette.-Abbé Colvil, of Tours.

Marivaux overflows: he begins well, but he does not know where to leave off.-Ablé $C$.

It is very often from our own ignoranee, and not from any fault in them, that the old writers seem to contradiet one another, and sometimes themselves so strangely. What seems to us to be downright contradietion in them, is sometimes nothing but different ways of expressing the very same thing.-Mr. Holdsworth.*

* It has been mentioned, at the head of this section, that parts are omitted, because the substance of them had been already published in the "Remarks and Observations on Virgil, with other Classical Observations;" edited by Mr. Spence, in 1768. In the Preface to that work, Mr. Spence says, "Mr. Ifoldsworth's excellent taste for poetry, and his superior talents in classical learning, and particularly in poetical criticism, have been as well known, and allowed as universally, as any person's of the age we live in. - He made more journeys to Italy than perhaps any gentleman of his age; and studied Virgil's works, in particular, on the very 
The Arar and Rhodanus in Livy, should be the Isara and Rhodanus. - That historian, in mentioning those two rivers, says that they both come from the $\mathrm{\Lambda} \mathrm{ps}$ : which is true of the Isaru, and not of the Arar. This is the river which we pass and repass so often, in going from Lyons to Mount Cenis; it falls into the Rhone near Valenee.- $I I$.

IIamilnal, aceording to Livy, lid not go over Mount Cenis; but passed a little on the right of it: and others will have it, that he passed so much on the left as Mount St. Bernard: but then he would not have eome into the country of the Taurini, so soon as by all aceounts hedid.-II.

Polybius is much more to le trusted, in his aecount of Hannibal's passage of the $\mathrm{Al}_{\mathrm{l}} \mathrm{s}$, than any other historian. He lived but a little after IIamnibal's time ; and went himself to trace his marehes over those mountains. He makes him pass a little on the left of Mfount Cenis; and descend into the Milanese. That road had been often used before;

spot where he wrote them."-" IIis prineipal aim was to acquire a more perfect insight into the Georgics; of which he intended to have given a new edition.-Mr. Hollsworth's last years were attended with almost constant ill-health, which preventerl his setting his last hand to the work." - "Several other observations of this kind I had been aecuainted with many years befure his death : I first having had the happiness of meeting with him at Florence in 1732; and of being fuvoured with a great dlegree of his intimacy and friendship. He soon communieated his design, and particular thoughts on Virgil to me with the greatest freelom. I took notes, that I might not lose his thoughts, which were so very valuable to me."-" Of the remarks which I could remember from his conversation, many have been already printed in the Virgil published by the ingenious Mr. Warton." - These publications are well known to the classical reader of taste, and the few articles which I have retained, are such as from their nature did not find a place in them.-Editur. 
and Hannibal was invited over by a Regulus of the Boii, a people that lived in the Milanese, who were at enmity with the Taurini.- $H$. [Mr. Holdsworth spoke slightingly of Livy in general, for his beautifying and making fine speeches rather than true ones; and being more of a romance-writer, than an historian. He commended Polybius for a good and solid writer, and one that might be safely confided in.-Spence.]

One of Martial's friends had a delightful villa near Rome; which he celebrates and points out very distinctly (Lib. i. Epig. 64). It was on that delicious little hill where the Villa Madama now stands: the garden theatre is still shown, in which they acted Guarinis's Pastor Fido ; and where Barclay wrote his Argenis.- $H$.

What they now show for a Temple of Janus in the Forum Boarium, was only an open place there, of which they had one in all their forums, (like the openings under part of our market-houses, ) for the convenience of people to deal and converse in when it rained. The Romans using the name of Janus for an open areh, probably led people into this mistake. $-H$.

The Lacus Fucinus could not have been drained all at onee: Claudius began upon it; and Suetonius says, the work was, invidia snccessoris intermissum, (Claud. C. 21.) People have puzzled themselves so much, and accused Suetonius of contradicting himself, in his account of this matter, purely from their own ignorance, and having got it into their heals that all the water must have been let out at the same time.* Claudius actually sunk it twice, and

* The Lake is thirty miles round; so that if the ground had proved good it would have been a considerable acquisition. The drain remains through which Claudius carried off part of the water. 
then probably quitted his design, on finding it so rocky, that the ground would have been good for nothing. -11 .

'The Greeks of old were of as romantic a turn as the Spaniards in more modern times; and possibly might deal as much in romances. The Eq $q \sigma a x \alpha$ of Xenophon the Ephesian, is a remainder of this kind, which might have been as unknown to us as the rest, had not our friend Dr. Cocehi found it out in the Lorenzo Library, and published it. $-H$.

Mr. Adlison originally designed to have taken orders;* and was diverted from that design, by being sent abroal in so encouraging a manner. It was from thenee that he began to think of publie posts; as being made Secretary of State at last, and sinking in his eharaeter by it, turned him back again to his first thought. Ife had latterly an eye toward the lawn: and it was then that he began his Evidenees of Christianity : and had a design of translating all the Psalms, for the use of ehurehes. Five or six of them that he did translate were published in the Spectators.-Pope.

Mr. Holdsworth's euriosity earried him so far into it, and the place was so filled with damp, stagnant water, and rapour, that it gave him a rleelmatism, which often returnel, and hung about him as long as he lived. How mueh do I wish that Clatudius had either never began, or had quite finished that work, and stopped up his drain! For it seems to have much eontributed toward shortening the days of one uf the most intelligent of men, and one of the most sincere of friends. - Spence.

* He himself speaks of this design in the close of his verses to Sacheverel; written in $\mathbf{1 6 9 4 .}$

"I leave the arts of poetry and verse To them that practise them with more suceess, Of greater truths I'll now prepare to tell." 


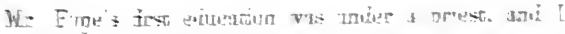

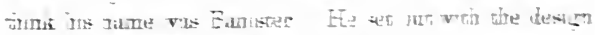

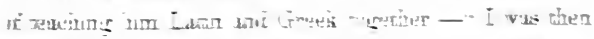

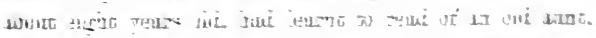

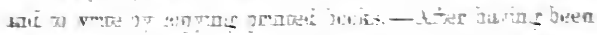

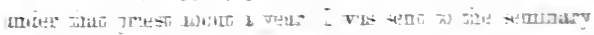

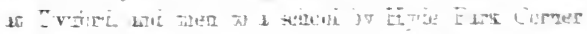

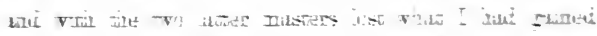

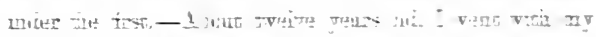

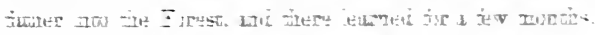

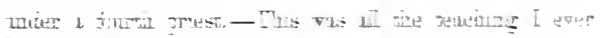

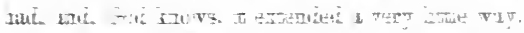

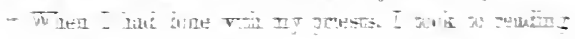

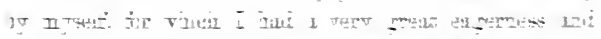

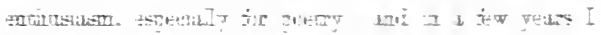

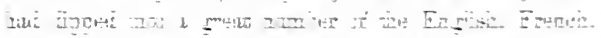

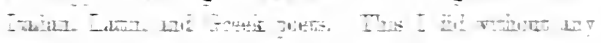

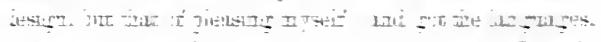

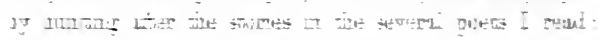

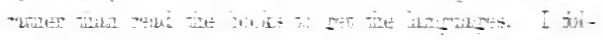
A

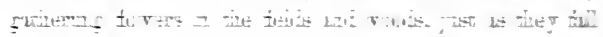

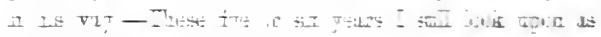

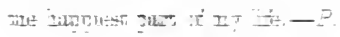

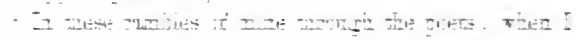
I

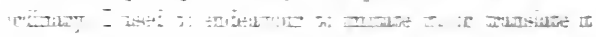

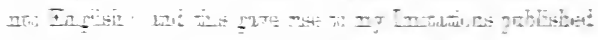

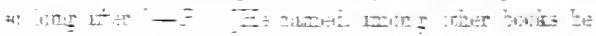

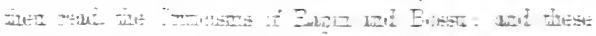

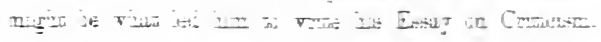




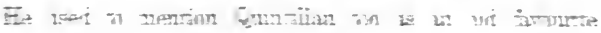

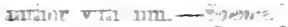

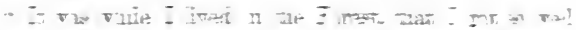

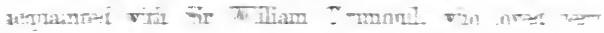

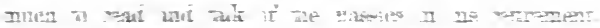

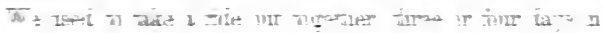

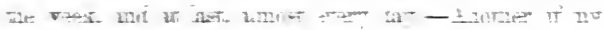

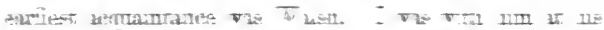

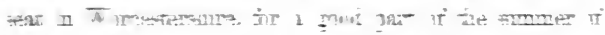

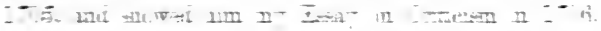

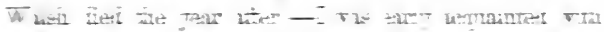

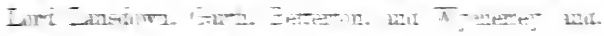

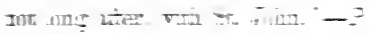

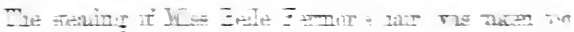

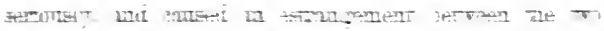
ำ

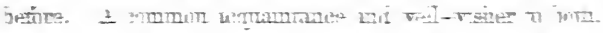

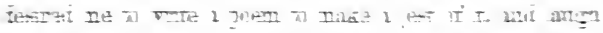

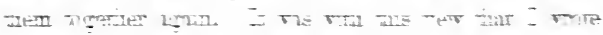

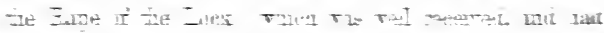

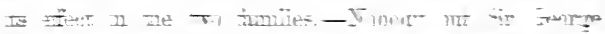

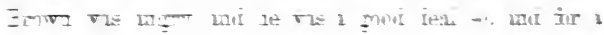

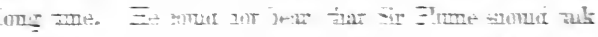

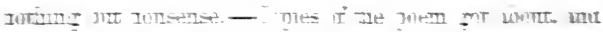
I $\nabla$ I

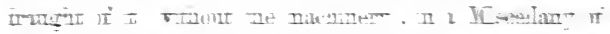

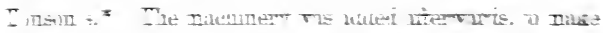

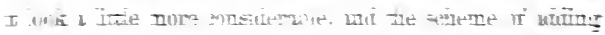

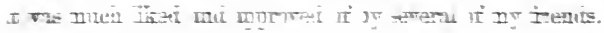

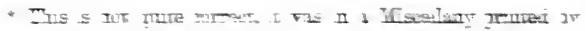

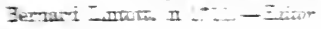


and particularly by Dr. Garth: who, as he was one of the best natured men in the world, was very fond of it. $-P$. [I have been assured by a most intimate friend of Mr. Pope's, that the Peer in the Rape of the Lock was Lord Petre; the person who desired Mr. Pope to write it, old Mr. Caryl, of Sussex; and that what was said of Sir George Brown in it, was the very pietnre of the man.-Spence.]

My aequaintance with Mr. Addison commenced in 1712: I liked him then as well as I liked any man, and was very fond of his conversation. It was very soon after, that Mr. Addison advised me " not to be content with the applause of half the nation." He used to talk much and often to me, of moderation in parties: and used to blame his dear friend Steele for being too much of a party man. He encouraged me in my design of translating the Iliad, which was begun that year, and finished in 1718. $-P$.

When Mr. Addison had finished his Cato, he brought it to me; desired to have my sincere opinion of it, and left it with me for three or four days. I gave him my opinion sineerely, which was, " that I thought he had better not act it, and that he would get reputation enough, by only printing it." This I said, as thinking the lines well written, but the piece not theatrical enough.-Sometime after Mr. Addison said; "That his own opinion was the same with mine: but that some particular friends of his, whom he could not disoblige, insisted on its being acted." And so it was, you know, with the greatest applause. $-P$.

Addison's ehief companions, before he married Lady Warwick (in 1716), were Steele, Budgell, Philips, Carey, Davenant, and Colonel Brett. He used to breakfast with one or other of them, at his lodgings in Saint James's 
Place, dine at turerns with them, then to Button's, and then to some tavern again for supper in the evening: and this was then the usual round of his life.-P.

Steele had the greatest veneration for Addison, and used to show it, in all companies, in a partieular manner. Addison, now and then, used to play a little upon him; but he always took it well.- $P$.

When I was very young. I wrote something toward a tragedy,* and afterwards an entire one. The latter was built on a very moving story in the Legend of St. Geneviève. After I had got aequainted with the town, I resolved never to write anything for the stage: though I was solieited by several of $\mathrm{my}$ friends to do so, and particularly by Betterton, who (among other things), would have had me turn my early Epie Poem into a tragedy.-I had taken such strong resolutions against anything of that kind, from seeing how much everybody that did write for the stage, was obliged to subject themselves to the players and the town. $-P$.

The Deuealion in my Epie Poem, was a second Deuealion, not the husband of Pyrrha.-I had flung all my learning into it, as indeed Milton has done too mueh in his Paradise Lost.-The Bishop of Rochester, not many years ago, advised me to burn it: I saw his advice was well grounded, and followed it, though not without some regret. $-P$.

There were several verses of mine inserted in Mr. Wyeherley's Poems, here and there; and particularly in those

- Perhaps this was only that tissue of speeches, collected by him from Oyilby's Homer, and joined together by some verses of his own; which he got his schoolfellows to act, whilst he was at the little seminary at Hyde Park Corner.-Spence. 
On Solitude,-On a Life of Business,- and on a Middle Life.-P.

Wycherley used to read himself asleep o'nights, either in Montaigne, Rochefoueault, Seneca, or Gracian; for these were his favourite authors.-He would read one or other of them in the evening, and the next morning, perhaps, write a copy of verses on some subject similar to what he had been reading: and liave all the thoughts of his author, only expressed in a different mode, and that without knowing that he was obliged to any one, for a single thought in the whole poem. I have experienced this in him, several times, (for I visited him for a whole winter, almost every evening and morning,) and look upon it as one of the strangest phenomena that $\mathrm{I}$ ever observed in the human mind.- $P$.

Stanley's poems consist ehiefly of translations, but of well chosen pieces.-His treatise of the Sentiments of the Old Philosophers is very good.- $P$.

Middling poets are no poets at all. There is always a great number of such in each age, that are almost totally forgotten in the next. A few curious inquirers may know that there were such men, and that they wrote sueh and such things; but to the world they are as if they had never been.- $P$.

Scaliger's Poetics, is an exceeding useful book in its kind, and extremely well collected.- $P$.

How very strange and inconclusive does the reasoning of Tully and Plato often appear to us! and particularly that of the latter in his Phædo._- "Is there not something like a fashion in reasoning?"-I believe there may, a good deal ; but with all that, there certainly is not any one of the ancients who reasons so well as our Mr. Locke, or even as Hobbes. 
In my first setting out, I never read any Art of Logic or Rhetorie. I met with Locke, he was quite insipid to me. I read Sir William Temple's Essays too then, but whenever there was anything politieal in them, I had no manner of feeling for it. -1 '.

There is a great number of exceeding good writers among the French. They don't indeed think so closely, or speak so elearly, as Locke; but they think and speak better than most of our other writers. $-P$.

I have nothing to say for rhyme, but that I doubt whether a poem can support itself without it, in our language; unless it be stiffened with such strange words, as are likely to destroy our language itself. The high style, that is affeeted so mueh in blank verse, would not have been borne, even in Milton, had not his subject turned so mueh on sueh strange out-of-the-world things as it does.- $P$.

Old Jacob Tonson did not like Mr. Addison. He had a quarrel with him: and after his quitting the secretaryship, used frequently to say of him: "One day or other, you'll see that man a bishop! I'm sure he looks that way: and, indeed, I ever thought him a priest in his heart." $-P$.

The mass of mankind are generally right in their judgments: at least, they have a very good medioere taste. As to higher things, it requires pains to distinguish justly : they are not fit for the crowl: and even to offer such to them is, as Ben Jonson* says, giving eaviare to the multitude. $-P$.

Lord Rochester's charaeter of Wycherley is quite wrong.

* Can this be Pope's mistake, or is it chargeable upon his friend Spence ?-I am afraid that Pope's acquaintance with Ben Jonson was not very extensive, and perhaps he did not relish Shakespeare mure than he seems to have done Milton.-Editor. 
He was far from being slow in general, and in particular. wrote the Plain Dealer in three weeks. $-P$.

The little copy of verses on Ditton and Whiston, in the third volume of the Miscellanies, was written by Gay ; that on Dennis, by myself: and the Origin of the Sciences. from the Monkeys in Ethiopia, by me, Dean Parnell, and Dr. Arbuthnot. $-P$.

Lord Oxford was not a very capable minister, and had a good deal of negligenee into the bargain.* He used to send trifling verses from court to the Seriblerus-club almost every day, and would come and talk idly with them almost every night: even when his all was at stake.-He talked of business in so confused a manner, that you did not know what he was about; and everything he went to tell you was in the epic way; for he always began in the middle.-They were quite mistaken in his temper, who thought of getting rid of him, by advising him to make his escape from the Tower. He would have sate out the storm, let the danger be what it would.- - He was a steady man, and had a great firmness of soul, and would have died unconcernedly : or, perhaps, like Sir Thomas More, with a jest in his mouth.- $P$.

* It may be worth while to oppose to this opinion of Pope, that of Swift, who, in a letter to Archbishop King, says; "The Lord Treasurer is the greatest minister I ever knew : regular in life, with a true sense of religion, an excellent scholar, and a good divine, of a very mild and affable disposition, intrepid in his notions, and indefatigable in business, an utter despiser of money for himself, yet frugal (perhaps to an extremity), for the public. In private company he is wholly disengaged, and very facetions, like one who had no business at all." Yet Swift knew the great foible of his friend, and in his frank and familiar manner occasionally told him of his fault, which appears to have been a sort of indolent procrastination, rather than negligence.-Editer. 
On somebody's saying of a measure proposed, that the people would never bear it, Lord Oxford's answer was. "You don't know how far the good prople of England will bear." $-P$.

Lord Lansdowne insisted on my publishing my Windsor Forest, and the motto (non injussa cano), shows it. $-P$.

Mr. Addison and his friends had exclaimed so much against Gay's " Three Hours after Marriage," for obseenities, that it provoked him to write " $A$ Letter from a Lady in the City to a Lady in the Country," on that subjeet. In it he quoted the passages which had been most exclaimed against, and opposed other passages to them from Addison's and Steele's plays. These were aggravated in the same manner that they had served his, and appeared worse. Inal it been published it would have male Addison appear ridieulous, which he conld bear as little as any man. I therefore prevailed upon Gay not to print it, and have the manuscript now by me.- $P$.

No writing is good that does not tend to better mankind some way or other.-Mr. Waller has said, " that he wished everything of his burnt, that did not drive some moral."Even in love verses it may be flung in by the way.- $P$.

Mr. Pope was born in the City of London, in Lombard Street, at the house whieh is now one Mr. Morgan's, an apotheeary.-P. and Hooke.

Our flattering ourselves here with the thoughts of enjoring the company of our friends when in the other world; may be but too like the Indians thinking, that they shall have their dogs and their horses there. $-P$.

A metempsychosis is a very rational scheme, and would give the best solution of some phenomena in the moral world.-P. and $\mathrm{V} r \mathrm{r} . L \ldots$ 
It is vanity which makes the rake at twenty, the worldly man at forty, and the retired man at sixty. We are apt to think that best in general, for which we find ourselves best fitted in particular.-Everybody finds that best and most commendable that he is driving, whilst he is driving it: and does not then suspect, what he chooses afterwards, to be half so good.-If a man saw all at first, it would damp his manner of acting: he would not enjoy himself so much in his youth, nor bustle so much in his manhood.-It is best for us to be short-sighted, in the different stages of our life, just in the same manner as it is best for us in this world not to know how it is to be with us in the next.-P.

Browne* is an excellent copyist, and those who take it ill of him are very much in the wrong. They are very strongly mannered, and perhaps could not write so well if they were not so: but still it is a fault that deserves to be pointed out. $-P$.

There is no one study that is not capable of delighting us after a little application to it.-." How true of even so dry a study as Antiquities !"-Yes, I have experienced that myself. I once got deep into Grevius, and was taken greatly with it: so far as to write a treatise in Latin, collected from the writers in Grævius, on the Old Buildings in Rome. It is now in Lord Oxford's hands, and has been so these fifteen years. $-P$.

"Do you remember anything of two Capitoliums at Rome?"-Yes, there certainly were two.- $P$. [This he answered much more readily and directly than Mr. Holdsworth himself, who was so particularly well acquainted with Rome and its Antiquities. The former of these Capitols

* In his Pipe of Tobacco.-Dpence. 
was built by Tarquinins Prisens, near the place where the Barberini Palace now stands, and was ealled Capitolium vetus: the other, by the seeond Tarquin, on the hill, which was thence called the Capitoline hill.-Spence.]

La Cerda observes, " That slowuess makes the majesty of verse," and the truth of that observation will appear, by comparing only the beginning of Virgil's Eneid with the beginning of his Eelogues.-Mr. Auditor Benson.

The strongest eontrast of versifieation $I$ am aequainted with is in Virgil's story of Aristeus.* And the softest couplet that was ever written is in the same.†-Sir John Denham's eelebrated eouplet on the Thames, owes a great part of its fineness to the frequeney and variety of the pauses.-Erythræus, above two hundred years ago, has shown all the mysteries of fine versification.--Vossius's treatise de Rhythmo, is a wretched silly thing.-I have seen English verse of Havillan's.-Mr. A. B. [Havillan was one of the most eelebrated men of his time for Latin verse, and is the only Latin poet, of all our countrymen, that is recommended by Ludoviens Vives in his treatise, “De tradendis Disciplinis." (Lib. iii. p. 542.) If there be any English poem of his extant, it must be a great curiosity, for he lived above a hundred years before Chancer's time.-Spence.]

My brother was whipped and ill-used at Twiford school for his satire on his master, and taken from thence on that

* "Unde pater Tiberinus, et unde Aniena fluenta, Saxosumque sonans Hypanis, Mysusque Caïcus."

Georg. iv. 369, 370 .

$\dagger$ " Te, dulcis conjux, te solo in littore secum,

Te veniente die, te decedente canebat."

Ib. $465,466$. 
account.-I never saw him laugh very heartily in all $\mathrm{my}$ life.-Mrs. Racket, speaking of Mr. Pope. [This is odd enough ! because she was with him so much in all the first part of his life, when he is said, by persons most intimate with him, to have been excessively gay and lively. It is very true, that in the latter part of his life, when he told a story, he was always the last to laugh at it: and seldom went beyond a particular easy smile, on any occasion that I remember.-Spence.]

"Imperatorem decet stantem mori," seems such odd sense to us, partly from our having shifted the sense of the word Imperator.-It then signified a commander or general, not an emperor. " A general should die in action," is much the same sentiment with that of marshall Villars, when he was told of the death of the Duke of Berwick.Mr. Holdsworth.

We often stare at the customs of other countries, and condemn them only from our ignorance of the original design of them. What scems more ridiculous than that the blacks should cut and slash their faces by way of ornament? and yet if we consider their perpetual wars, and that this may be designed to make them less afraid of wounds in the face, it would not be ridiculous at all.-Mr. $H$.

Rabelais had written some sensible pieces, which the world did not regard at all.- " I will write something, (says he,) that they shall take notice of:" and so sat down to writing nonsense.-Everybody allows that there are several things without any manner of meaning in his Pantagruel. Dr. Swift likes it much, and thinks there are more good things in it than I do.-Friar John's character is maintained throughout with a great deal of 
spirit.-ITis concealed characters are touched only in part, and by fits : as for exmmple, though the King's Mistress be meant in such a particular, related of Gargantua's mare; the very next thing that is said of the mare, will not, perhaps, at all apply to the Mistress. $-P$.

Butler set out on too narrow a plan, and even that design is not kept up. He sinks into little true particulars about the Widow, \&e.-The enthusiastie Knight, and the ignorant squire, over-religious in two different ways, and always quarrelling together, is the elief point of view in it.- $P$. [Hudibras's character is that of an enthusiast for liberty, and so high and general a one, that it earries him on to attempt even the delivery of bears that are in chains. $-M i . L$.

"I can't conceive how Dinocrates could ever have earrich his proposal of forming Mount $\Lambda$ thos into a statue of Alexander the Great, into execution."-For my part, I have long sinee had an idea how that might be done; and if anyborly would make me a present of a Weleh mountain, and pay the workmen, I would undertake to see it exeeuted. I have quite formed it, sometimes, in my imagination. The figure must be in a reclining posture, because of the hollowing that would otherwise be necessary, and for the eity's being in one hand. It should be a rude unequal hill, and might be helped with groves of trees for the eycbrows, and a wood for the hair. The natural green turf should be left wherever it would be neessary to represent the ground he reciines on. It should be contrived so that the true point of view should be at a eonsiderable distanee. When you were near it, it should still have the appearance of a rough mountain; but at the proper distance sueh a rising should 
be the leg, and such another an arm. Itwould be best if there were a river, or rather a lake, at the bottom of it, for the rivulet that came through his other hand, to tumble down the hill, and discharge itself into it.*-P.

The lights and shades in gardening are managed by disposing the thick grove work, the thin, and the openings, in a proper manner: of which the eye is generally the properest judge.-Those clumps of trees are like the groups in pietures, (speaking of some in his own garden.)-You may distance things by darkening them, and by narrowing the plantation more and more towards the end, in the same manner as they do in painting, and as 'tis executed in the little eypress walk to that obelisk. $-P$.

There are several passages in Hobbes's translation of Homer, which, if they had been writ on purpose to ridicule that poet, would have done very well. $-P . \quad[$ He gave several instances of it, and partieularly in the very first lines, the Iehor, and the two tumblers at a feast.-Spence.]

In looking on the portrait of the Pope by Carlo Maratti, at Lord Burlington's, he ealled it " the best portrait in the world.-I really do think him as good a painter as any of them," were his words. $-P$.

When the Marquis Maffei was at Mr. Pope's at Twick-

* It is somewhat singular that Mr. Pope should have thought this mad project practicable, but it appears there are still persons who dream of such extravagant and fruitless undertakings. "Some modern Dinocrates had suggested to Buonaparte to have cut from the mountain of the Simplon an immense colossal figure, as a sort of Genius of the Alps. This was to have been of such enormous size, that all the passengers should have passed between its legs and arms, in a zig-zag direction."-Mrs. Baillies's Tour on the Continent, 1819, 8vo. p. 218. 
enham, the latter showed him the design of an Aneient Theatre at Verona. The Marquis sail the artist had done very well, but that it was all a whim. (Furola!) Mr. Pope begged his pardon, assured him that 'twas a reality: and convinced him that it was so, from an allowed old writer on the Antiquitics of Verona.-P.

Lord Bolingbroke is not deep either in pictures, statues. or arehitecture.- $P$. [I had been asking him what that Lord's opinion was of the Aehilles' Story, among the sculpture at Cardinal Polignae's ; and he said that Lord B. spoke but lowly of them.-Spence.]

Speaking of Dr. A. Clarke, he said, "The man will never be contented! He has already twice as much as I ; for I am told he has a good thousand pound a year, and yet he is as eager for more preferment as ever he was.-

"Let Clarke make half his life the poor's support, But let him give the other half to court ;"

Was a couplet in the manuscript for the fourth book of the Duneiad: but I believe I shall omit it; though, if rightly understool, it has more of commendation than satire in it. - The best time for telling a friend of any fault he has, is while you are commending him; that it may have the more influence upon lim. And this I take to be the true meaning of the character which Persius gives of IIorace :-

"Omne vafer vitium ridenti Flaceus amico

Tangit; et admissus circum præcordia ludit." - Pope.

I had all the subscription moncy clear, for the Iliad, and Tonson was at all the expense of printing, paper, \&e. for the copy.-An author who is at all the expenses of publishing, ought to clear two-thirds of the whole profit into 
his own pocket.-P. [For instance, as he explained it, in a piece of one thousand copies, at three shillings each to the common buyer; the whole sale at that rate, will bring in one hundred and fifty pounds ; the expense therefore to the author, for printing, paper, publishing, selling, and advertising, should be but fifty pounds, and his clear gains should be one hundred pounds.*_-Spence.]

Mr. Pope's not being richer may be easily accounted for. - He never had any love for money $: \dagger$ and though he was not extravagant in anything, he always delighted, when he had any sum to spare, to make use of it in giving, lending, building, and gardening; for those were the ways in which he disposed of all the overplus of his income.--If he was extravagant in anything it was in his grotto, for that, from first to last, cost him above a thousand pounds.-Mrs. Blount.

"What is your opinion of placing prepositions at the end of a sentence?"-It is certainly wrong: but I have

* There must be some mistake in this statement of Mr. Spence's. Did not Mr. Pope mean that an author should clear two-thirds of the prifits rather than of the whole proceeds of a book? Mr. Spence's after experience must surely have set him right upon this subject, although he was a successfil author, having cleared one thousand five hundred pounds by his Polynetis alone! In these degenerate times, I believe, very few writers have been enabled to clear onethird of the whole proceeds of the most successful publication, except in some very few cases, where the cony-right has been sold for a very large sum.-- Editor.

+ This does not appear to be true, Pope himself professed to be careless abcut wealth : but he seems ever to have been solicitous to accumulate it, and risked his money on all kinds of securities for this purpose. He was ostentatious too, yet mean; and the whole of this statement of Mrs. Blount's is a greater proof of her partiality than of her love of truth.-Editor. 
made a rule to myself about them some time ago, and I think verily'tis the right one. We use them so in eommon conversation: and that use will authorize one, I think, for doing the same in slighter pieces, but not in formal ones. In a familiar letter for instance, but not in a weighty one: and more particularly in dialogue writing, but then it must be when the people introduced are talking, and not where the author appears in his own person.- 1 .

"I wonder how Horace eould say such coarse obscene things in so polite an age, or how such an age could allow of it?"--'Tis really a wonder, though it was the same with us in Charles the Seeonl's time, or rather worse. Ilowever it was not above five or six years, even in that witty reign, that it passed for wit, as the saying of wieked things does among us now.-I wish there were not too great remains of the former vice still, even among people of the first fashion ; but the prevailing notion of genteelness consisting in freedom and ease, has led many to a total negleet of deceney, either in their words or behaviour.-True politeness eonsists, in being easy oneself, and making everybody about one as easy as one can. But the mistaking brutality for freedom, for which so many of our young people of quality have made themselves remarkable of late, has just the contrary effect. It leads them into the taking of liberties whieh often make others uneasy, and ought always to make the aggressors themselves so.- $P$.

Gay was quite a natural man, wholly without art or design, and spoke just what he thought, and as he thought it.-IIe dangled for twenty years about a eourt, and at last-was offered to be made Usher to the young Princesses.-Secretary Craggs made Gay a present of stock in 
the South Sea year: and he was once worth twenty thousand pounds, but lost it all again. He got about four hundred pounds by the first Beggar's Opera, and eleven or twelve hundred by the seeond.-He was negligent and a bad manager:-latterly the Duke of Queensbury took his money into his keeping, and let him have only what was necessary out of it: and as he lived with them he eould not have occasion for much: he died worth upwards of three thousand pounds.- $P$.

Otway* has written but two tragedies, out of six, that are pathetic.-I believe he did it without much design; as Lillo has done in his Barnwell.-'Tis a talent of nature, rather than an effeet of judgment, to write so movingly. $-P$.

Somebody had been speaking of Bayle's manner in his Dictionary :- -upon which Mr. Pope said: "Ay, he is the only man that ever colleeted with so much judgment, and wrote with so much spirit at the same time." - $P$.

'Tis difficult to find out any fault in Virgil's Eelogues or Georgies.-He could not bear to have any appear in his Eneid; and therefore ordered it to be burnt.- $P$.

Virgil is very sparing in his eommendations of other poets; and searce ever does it, unless he is forced.- He

* The following notice of Otway by a cotemporary, who still lived in the middle of the last century, was communicated to the Gentleman's Magazine in 1745. "His person was of the middle size, about five feet seven inches high, inclinable to fatness. He had a thoughtful speaking eye, and that was all. He gave himself up early to drinking, and like the unhappy wits of that age, passed his days between rioting and fasting, ranting jollity, and abject penitence, carousing one week with Lord Plymouth, and then starving a month in low company at an ale-house on Towerhill."-Editur. 


\section{SECTION I. 1737-39.}

hints at Theoeritus* beeause he had tnken so much from him, and his subject led to it; and does the same by IIesiod.t for the same reasons. He nerer speaks a single wort of Homer: and indeed could not do it, where some would have had him, beeause of the Anachronism. They have blamed him for not mentioning Homer, instead of Mnsiens (An. vi. 607.), without considering, that then Itomer must have been put into Elysium long before he was born.- $P$.

Virgil's trimph over the Greek poets in his Georgies, is one of the vainest things that ever was written.-There are not above two or three lines in Virgil from Hesiod's Works, he acknowledges imitating that poet; and would never do so, for two or three lines only.-Perlaps what we call IIesiod's Works, at present, are misnamed. The Theogony has little prettinesses in it, not like the greatness of antiquity. - The Shield of Hereules is taken from Homer's Shield of Achilles, and there are several lines exactly the same in both. The $\mathrm{H}_{\mu \varepsilon \rho \omega v}$, has the truest air of antiquity. -Nudus aress is, I think, from the Egrwv: but possibly none of it is Hesiod's.-P.

Virgil's great judgment appears in putting things together, and in his pieking gold out of the dunghills of the old Roman writers.-IIe borrowed even from his cotemporaries, as I think Aulus Gellius tells us.--The Eneid was evidently a party piece: as mueh as $\mathrm{Absalom}$ and

- Prima Syracosio dignata est ludere versu Nostra, nec erubuit silvas habitare, Thalia.

Lcl. vi. 1,2 .

$\dagger$ Ascreumque cano Romana per oppida carmen.

Georg. ii. 176.

† Genrg. iii. 10-22.

§ Ib. i. 299. 
Achitophel.-I have formerly said that Virgil wrote one honest line,

"Secretosque pios, his dantem jura Catonem,"

and that, I now believe, was not meant of Cato Uticensis.- $P$.

Otho Vænius has published a picture-book, which he calls the Emblems of Horace. "Nisce consiliis stultitiam brevem," is represented by Minerva leading a little short child, with a fool's cap on, by the hand.- " Paulum sepultre distat inertia celata virtus," is Virtue in a dark corner, Laziness in a sepulchre, and only a thin partition-wall between them.- $P$.

Nil Admirari, is as true, in relation to our opinions of authors, as it is in morality ; and one may say, $O$, admiratores, servum pecus! full as justly as $O$, Imitatores! $-P$.

What terrible moments does one feel, after one has engaged for a large work!- In the beginning of my translating the Iliad, I wished anybody would hang me, a hundred times.-It sat so heavily on my mind at first, that I often used to dream of it, and do sometimes still.*-When I fell into the methorl of translating thirty or forty verses before I got up, and piddled with it the rest of the morning, it went on casy enough; and when I was thoroughly got into the way of it, I did the rest with pleasure.- $-P$.

* He used to dream that he was engaged in a long journey, puzzled which way to take; and full of fears that he should never get to the end of it.-Spence. 


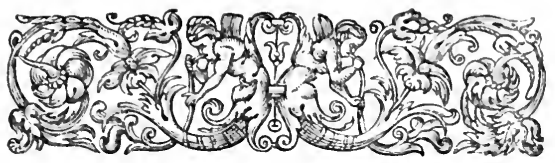

\title{
SPENCE'S ANECDOTES.
}

\author{
SECTION VI.* $1740-41$.
}

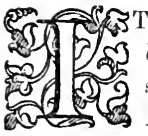

was Cardinal Mauriee who bought the Tabula Isicece, after the taking of Mantua, and sent it to Turin; where it is now kept in the Archives of the Royal Aeadeny. It is one of the finest Egyptian antiquities in the world, and had run a great many risks of being destroyed. At the sacking of Rome, five years before, it was suld to a locksmith. Bembo bought it of him and gave it to the Duke of Mantua. At Mantua it fell into the soldiers' hands again, and was saved the seeond time by the Cardinal of Saroy. It is a sort of table, of a particular metallie eomposition, four feet two inehes long, and two feet and a half wide. The ledges

- Sereral articles relating to the King of Saroy and his states, at the commencement of this section, are left out, because statistical accounts of that period are certainly out of their place bere.-The seventh and eighth centuries, (according to Mr. Spence's division,) are here blendled into one section; many unimportant and unin. teresting articles being omitted, together with some which had been printed before, such as the Account of Magliabecchi, \&c. 
are two inches and a quarter, and figured. The figures on the table are, or were, all inlaid. They are neater, and of a better taste than those on the obelisks, but not so high as some Egyptian statues and relievos at Rome. They are dispersed in three long compartments or ranges, and in the midst of the second range Isis sits enthroned; whence it is called the Mensa Isiaca. The things inlaid are of a different colour to the groundwork or table itself, there is a great deal of mighty pretty silver work among it, and you see the places where there was more, before the soldiers picked it ont to sell it. They found it so thin that it was searce worth while, or met with a purchaser for the table before they had time to do more damage to it. $-M r . D . V$.

Emanuel the First, and his son the Cardinal Maurice, were pretty active in making a collection of statues, busts, medals, and pictures. Emanuel the Second began a gallery for them, which would have been one of the most considerable in Italy._-The late king (Victor), was so perpetually engaged in affairs of much greater consequence to his family and his country, that the taste for the arts, which began to arise, was quite chilled, and continues so to this day. Most of the antiques that had been got together, were flung as rubbish into a ground room of the palace, and that part of the gallery which was built for them is turned into archives and offices for the Secretaries of State.-Mr. D. $V$.

There was a God called Pennus, much worshipped, on the great St. Bernard, some remains of his temple, and I think of his statue, are still to be seen there-Count Richa. [Pen signified high or chief. Hence the Alpes Pennince, 
and the Apennines in Italy. And with us the Pen ap pen, near 1 ligh Wyeomb in Buckinghamshire: the old l'ennoerusium or Penkridge in staffordshire: Pemlennis in Cornwall: Penmanmawr, and many others, in North Wales. -spence.]

When you eome near Poverino, two posts from 'l'urin on the way to Alessandria, the sand looks just like the sea shore: I have tried it in several places, and have always found a stratum of shells five or six feet under the surface. - Count Richa.

The finest remains I ever saw of the deluge are at Pianoro, the first post from Bologna in the way to Firenzuola. There are several picees of rock, full of shells, lie seattered behind the post-house, in the chamels that the torrents make as they fall down the Apennine: and in particular I remarked one square slab, large enough to make a table, which I have often wished I had brought away with me in my chaise - $\mathrm{H}, \mathrm{T}, \mathrm{*}^{*}$

There are no less than three of those strange fires, which constantly appear by night, on the road from Bologna to Florence.-When we were got a mile beyond Pietra Mala, we saw the largest of them: it was an eren yellow light. like the body of the sun, and seemed to be ahout three feet long and one broad.-At the place itself, they say, it is about ten feet long. There is no cavity: the earth on the spot is of a reddish colour, and so is the soil a good way round about it. It will burn a piece of paper if put into it, and may be lighted with a eandle when it does not appear of itself. The people of the eountry say it has been there time out of mind, and indeed it is mentioned so long ago

* Most probably Mr. Townley.-Editor. 
as by Pliny. It is oecasioned by what the Italians eall Oleo de' Sassi, and Physieians Petrolium, we Petrol, or oil of rock.-Mr. $T$.

The Court of Rome has more or less power in all the states of Italy. It is their interest that the people should be kept in ignoranee. Knowledge is therefore more or less discouraged everywhere, and if any person shows particular eagerness for it, they either drive him away, or at least oblige him to hold his tongue. When one consilers how far this is carried in most parts of Italy, one would rather wonder that there should be so mueh knowledge left, than that it should be so much fallen off among them.-There is no impunity for good sense in this country.-Lady 0 , at Florence.

Speaking of the King of Prussia and the present Pope (Benediet the Fourteenth), "Yes, they do well enough hitherto: they are but young kings, and searee know that they are kings yet; but let them alone a little, I am afraid you will find then as bad as the rest, in some time." Lady $O$.

That happiness you mention of England as an island, does not so much consist in the diffieulty of an invasion from a foreign power, as from the diffieulty which our own people have of flinging themselves into other lands.-Lady $O$.

The chief aim of any young nobleman on his travels should be, to make a man of sense his friend: as his great care should be not to be pleased with agreeable fools.Lady $O$.

I should rather think that the wise are happier than the fools, but indeed that must be all aceording to the eircumstances they fall under. A man of sense feels things more 
intensely than the fool, and consequently in the same good eireumstances must be happier, and in the same bad cireumstanees more unhappy.-Lat!y $O$.

The three first books in Giamnone's I History of Naples were not witten by him, and the rest that were, are but indifferent.-Lady $O$.

Petrarea, in his Somets to Laura, has some warmth at first, but he grows dull and falls asleep too soon.--Redi is the very best Italian writer that we have had of late.Lady $O$.

The best talkers, among the ladies at Naples, pique themselves on talking in Boceaccio's novel style.-Lady $O$.

I wonder how anybody ean find pleasure in reading the books which are that lady's chicf favourites!* There is no imitation of nature in the characters, and without that how is it possible for anything to please? - Wren the Princess of Cleves is monstrous and unnatural, in loving another while she loves her husband, and in not taking that other after her husband is dead.--Ifer firendship for her husband (if one must eall it by that strange name), need not have interfered at all with her making lierself happy after he was gone. Don Quixote is gool beeause it is natural, though 'tis such odd nature.-Lidly $O$.

The Venus de' Medici is placed in the tribuna, or ehief room in the great duke's gallery, between two other Venuses, the celestial and the victorious: if you observe them well, you will find as much differenee between her air, and that of the eelestial Venus, as there is between Titian's wife as a Venus, and as a Madonna in the same room.-Mr. T.

- i.e. Romances and novels. I gather from the first memoranda that Lady MI. W. Montague is the person here meant: I do not know who the speaker is, but probably Lady Oxford.-Editor. 
The famous Arretino, or Whetter, is in just the same attitude as the attendant at the feet of Apollo, in a gem which represents that god punishing Marsyas.-Baron Stosch. [It might be worth while to inquire where that fine statue was found, and to search for the rest of the figures of the group: for if this will hold, it is probable that it was not alone.-Spence.]

The little figure in the Tribuna, with a musieal instrument like a violin, is left rough and unfinished by the artist, particularly the violin and the stick to play on it :it is held as we hold our violins.-There are no buskins on the legs, but a fawn's skin over his back and breast, and he is crowned with ivy: the face is handsome, and there is a Bacchanalian air in the head. Bianchi used to say, that it was Orpheus who brought the Bacchanalian ceremonies into Beotia.-Mr. T. [I lave met but with two figures beside this with the modem violin. One of them is in a relievo, on the death of Orpheus, in the university at Turin: and the other is a statue, either of Orpheus or Apollo, in the Montalta gardens at Rome. It is unlucky that all three have something to be said against them. That at Florenee is an unfinished piece, and perhaps not quite indisputable: that at Turin, of a very bad taste or of a low age: and in that at Rome, the fiddle at least, is evidently modern.-Spence.]

There are two historical pieces in the Camera delli Cabinetti, in the great duke's gallery at Florence, by the famous Mantegna. Some of the faces are very well, but the manner in general is stiff and dry. The ground of both is all gold, and there is a good deal of gold in several other parts of the pictures. Mantegna was much the best 
painter in Europe, until Lionardo da Vinei so greatly advanced the art. It seems that the tawdry taste, brought into ltaly by the Greeks, ${ }^{*}$ continned quite down to the improvenents of the latter; and the banishing of it ought, most probably, to be reckoned among the many very high merits of that extraordinary man.- M $M$. T.

There is a loadstone in the Camera Mutematica, which holds up a piece of iron of forty pounds weight fast to it ; two of double or treble that power.might have kept up an iron eoffin, perhaps with Mahomet in it, suspended in the air. $-M r . T$.

In the Camera Madama there are two groups of the Laocoon, the lesser is of a different design from the famous Laoeoon in the Belvedere, but the larger group is just like it.-It has the arm which was wanting to the celebrated Belvedere one, and might direet a good artist how to supply it. $\downarrow$ - Mi. T.

In the chamber of Painter's' Heads, drawn by themselves, out of two hundred and forty, there are but five from England, and not any one of these properly an Englishman. Kneller's is set up above all the rest, aud is full of his usual ranity: he has inserted his gold chain, diamond ring, and his house at Twickenham in the back ground. It is not much liked, and I believe it will soon be removed quite out of the room. We have no head of Correggio out of his modesty, nor of Carlo Maratti, for a reason just contrary.-Siy. Bianchi.

- About the year 1013.-Mantegna died in 1517,--Lionardo da Vinei in 1518 .

$\dagger$ Bandinelli has followed it in the Copy of this Group at the end of the gallery.-Biunchi. 
The Bust of Julius Cæsar, in the long open gallery, has a very weakly look, and resembles Mr. Pope as much as any bust that has been male on purpose for him.-Mr. $T$.

The Pan in the same gallery, who has a face fit to frighten people, has the eyes painted with red : but it has been probably done by somebody sinee it was placed there. Bianchi tried it, and the red colour came off on lis fingers. $-M r . T$.

Pescennius is the first emperor's head that is wanting in the gallery; there are several others wanting among his sucessors, and that whieh they call by the name of Albinus, is misnamed.-Bianchi and Baron Stosch.

The Bacehus that loolds a mask in his right hand, and leans on a boy that is going to steal some of his grapes, with something of a drunken and libidinous look: has its head joined on, and is therefore doubtful enongh.-Bianchini.

The Lyre in the hand of that Apollo so much adorned with tortoiseshell, and resting on a column of fine marble of different colours, is modern: and so is the plectrum which he holds in his other hand.- $-B$.

"Is not the pleasure in the face of that very pretty Bacehus, holding up a cantharus in his left hand, and regarding it so fondly, too violently expressed for the ancient manner?"--Yes: it is modern, and was seulptured by Sansovino. $-B$.

The heads of Romans are without beards, all the time between the elder Brutus and Adrian, exeept a head of Nero and of two or three before him, who let theirs grow on some melancholy oceasion. $-B$.

There is a very fine Caracalla, and a very fine Plautilla, in the great Duke's collection of gems, and three or four 
very wretehed one's before them. After their time the art fell, in genernl, though you have now and then a tolerable head after them. $-B$.

If Coypel has represented Chiron with a switeh in his hand, in his history of Achilles, there are as ridieulous things to be met with in some of the works of the ancient artists: and among these very gems there is one with a centaur upon it, holding a whip to lash himself upon oceasion.- $M r . T$.

In the great Dnke's colleetion of medals there are twelve of Antoninus Pius, each with a sign of the zodiac for the reverse, and eight with as many diflerent labours of Hereules. $-B$.

In the gold medals, the good taste ends with Pertinax, though there are some pretty good of Caraealla's, and particularly one with the Arch of Severus for the reverse. $-B$.

Montesquieu, in his Persian Letters, has described the manners and eustoms of the Turkish Ladies, as well as if he had been bred up among them.-Latiy Mary Wortley Montague, at Rome.

The ladies at Constantinople used to be extremely surprised to see me go always with my bosom uneovered. It was in vain that I said everybody did so among us, and added everything I could in lefence of it. They could never be reconciled to what they thought so immodest a eustom; and one of them, after I had been defending it to my utmost, said, "Oh, my sultana, you ean never defend the manners of your eountry, even with all your wit ! but I see you are in pain for them, and shall therefore press it no further."-Lady $M$. 
One of the highest entertainments in Turkey is having you to their baths. When I was introduced to one, the lady of the house eame to undress me; another high compliment they pay to strangers. After she had slipped off my gown, and saw my stays, she was very much struck at the sight of them, and cried out to the other ladies in the bath: "Come hither, and see how cruelly the poor English ladies are used by their husbands:- Y ou need boast indeed of the superior liberties allowed you, when they lock you thus up in a box !"-Lady $M$.

It was from the customs of the Turks, that I first thought of a septennial bill for the benefit of married persons, and of the advantages that might arise from our wives having no portions. - Lady $M$. [That lady's little treatise upon these two subjects is very prettily written, and has very uncommon arguments in it. She is very strenuous for both those tenets. That every married person should have the liberty of declaring, every seventh year, whether they choose to continue to live together in that state for another seven years or not: and she also argues, that if women had nothing but their own good qualities and merit to recommend them, it would make them more virtuous, and their husbands more happy, than in the present marketing-way among us. Slie seems very earnest and serious on the subject, and wishes the legislature would take it under their consideration, and regulate those two points by her system. -Spence.]

Sure there cannot be a more detestable set of beings upon the earth, than those anti-knight-errants, who run about only to ruin as many ladies as they can.-Lady $M$.

Lord Bacon makes beauty to consist in grace and mo 
tion.-Lady .K. [Mr. Loeke makes it eousist in colour and fignre. Perhaps the two definitions joined would make one muel better than either of them is apart._s spence.]

It was my fate to be much with the wits: my father was acquainted with all of them.- Iddison was the best company in the world.-I never knew anybody that had so much wit as Congreve.-Cir Richard Steele was a very good-natured man:-Ind Dr. Garth a very worthy one.Lacly $M$.

When I was young I was a great admirer of Ovill's Metamorphoses, and that was one of the chief reasous that set me upon the thoughts of stealing the Latin langnage.*Mr. Wortley was the only person to whom I eommunicated my design, and he encouraged me in it. I used to study

* What her biographer, Mr. Dallaway, says, seems to contra. dict this, and yet Mr. Spence eould not surely be mistaken. I hare the original notes of this conversation, which took place, January 5, 1; $+10-1$, at Rome: and as they were made immediately after, on the spot, it is most probable that they are eorrect. "The first dawn of her genius, (says MIr. Dallaway, ) "pened so auspieionsly, that her father resolved to enltivate the adrantages of nature by a seduluus attention to her early education. Under the same preeeptors as her brother, Viscount Newark, sle acquired the elements of the Greek, Latin, and French languages, with the greatest suceess. Her studies were afterwards superintended by Burnet, Bishop of Salisbury, and her translation of Epictetus received his emendation."-IIer maiden name was Lady Mary Pierrepoint, she was the daughter of Evelyn, Duke of Kingston, and Lady Mary Fielding, daughter of William Earl of Derby : and was born at Thuresby athut the year 1690.-Her husband was the intimate friend of Addlison and Steele. She went with him on his embassy to Constantinople, and after his recall lived at Twiekenham. Her latter year's were spent in Italy, and her letters from thenee are very interesting: there is no satisfactory account given why she was so lung separated from her native country.-Editor. 
five or six hours a day, for two years, in my father's library : and so got that language, whilst everybody else thought I was reading nothing but novels and romanees.-Lady $M$.

I don't remember that there was any such thing as two parties, one to set up Pope and the other Addison, as the chief poet of those times. 'Twas a thing that could not bear any dispute.-Lady $M$.

You are very wrong in thinking that Mr. Pope could write blank verse well: he has got a knack, indeed, of writing the other, but was he to attempt blank verse, I dare say he would appear quite contemptible in it.*-Lady $M$.

I admired Mr. Pope's Essay on Criticism at first, very much, beeause I had not then read any of the ancient crities, and did not know that it was all stolen.-Lady $M$.

Gay was a good-natured man, and a little poet.-Swift has stolen all his humour from Cervantes and Rabelais.Lady $M$.

I would never be acquainted with Lord Bolingbroke, because I always looked upon him as a vile man.-Lady $M$.

I have got fifty or sixty of Mr. Pope's letters by me.†-

* The younger Richardson relates, that when Lady Mary showed Pope a paper of her verses, in which he wished to make some trifling alterations, she said, "No, Pope, no touching, for then whatever is good for anything will pass for yours, and the rest for mine."- "Her letters (says Mr. Buwle), in unaffected lan. guage, good sense, and natural humour, are as much superior to Pope's, as his verses are superior to hers." The flippant Walpole could sce no merit of any sort in Lady Mary's letters from the East : and says, that when a child, "She was a dirty little thing, and that the habit continued with her."-Pope gave her the Homer he had used in translating, and she wrote a poem in the blank leaves; it was a small edition by Wetstein, and afterwards came into the possession of Walpole.-Editor.

$\dagger$ These letters were first given to the world by Dr. Warton, 
"You shall see what a godless he made of me in some of them, thongh he makes such a devil of me in his writings afterwards, without any reason that $I$ know of.-Larly $M$. [Several of these letters were on common subjects, and one in partieular, that odd description of an ()ld Mansion, which he also sent to the Duke of Buckingham in answer to one of the Duke's, containing a description of Buckingham 1Iouse. This may show that it was one of his favourite letters.-spence.]

I got a common friend to ask Mr. Pope, why he had left off visiting me? he answered negligently, that he went as often as lie used to do.-I then got Dr. Arbuthnot to ask him, What Laly .I. had done to him?--He said, that Lady M. and Lord IIervey had pressed him onee together (and I don't remember that we were ever together with him in our lives), to write a Satire on some certain persons, that he refused it: and that this had oceasioned the breach between us.*-Ladly $M$.

and have since been incorporated in Lady Montague's works, by Mr. Dallaway. They are also to be fond in Mr. Buwle's edition of Pope's works. $1807,8 \mathrm{vo}$. "It is impossible to peruse them, (says Mr. Bowle,) withont being struck with two circumstances: - Pope's apparent adiration of the Laty, and the wounded pride and disappointment which afterwards made him so bitter and unrelenting an enemy.-Editur.

* The cause of this quarrel between Pope and Lady Montague has never been clearly developed, nor is it known exactly at what period it tork place; their intimacy must have been on the decline about 1720 , for Lady Mary, in a letter to Lady Mar in that year, says, "I see sumetimes Mr. Cungreve, and very selde min Mr. Pore, who continues to embellish his house at Twickenham. He has made a subterrarean grotto, which be has furnished with luokingglasses, and they tell me it has a good effect. I send you some verses, addressed to Mir. Gay, who wrote him a congratulatory 
—_ Don't you really think so, Sir?" - I think, madam, that he writes verses very well._." Yes, he writes verses so well, that he is in danger of bringing even good verse into disrepute! from his all tume and no meaning." -Lady $M$.

"Leave him as soon as you can, (said Addison to me, speaking of Pope, he will certainly play you some devilish trick else: he has an appetite to satire!"- - Lady $M$.

"Yes, that satire was written in Addison's lifetime." (Speaking of the verses on Addison.)-Lady $M$.

In Spain, the people are so overrum with devotion, that they have not a grain of religion left among them.-On

letter on his finishing his house. I stifled these here, and I beg they may die the same death at Paris, and never go farther than your closet."-These very beautiful lines were suppressed, in consequence of the quarrel which subsequently took place; they are among the most impassioned of Pope's productions, and evidently speak the langriage of his heart.

" $\mathrm{Ah}$ friend! 'tis true-this truth you lovers know-

In vain my structures rise, my gardens grow,

In vain fair Thames reflects the donble scenes,

Of hanging mountains, and of sloping greens :

Joy lives not bere,- to happier seats it flies,

And only dwells where Wortuey casts ber eyes.

What are the gay parterre, the chequer'l shade,

The murning bower, the evening colunnade,

But soft recesses for uneasy minds,

To sigh unheard in, to the passing winds ?

So the struck deer in some sequester'd part

Lies down to die, the arrow at his heart,

He, stretch'd unseen in coverts hid frum day,

Bleeds drop by drop, and pants his life away."

"Pope's acquaintance with her probably began about the year 1716. His passions were suspended with regard to his farourite 
hearing the Ave-Mary bell, the Spaniards who happen to be in the theatre, and even the actors on the stage, fall down on their knees: and then rise again, and earry on their diversions as before. I French gentleman, who happened to be present on one of those oceasions, and who had never seen anything of the kind before, scemed at first extremely surprisel at it : then burst out a langhing, and eried out bis! bis! with a great deal of vehemence.Siig. $N$.

The courtezans there do something of the same nature that is yet more extraordinary.-They are very great wor-

Blounts, and his heart captivated by the smiles of the young, the beantiful, the fashionable, the aceomplished Larly Mary Wortley Montagne. He proceeded with great caution : first with extreme flattery to her intelleet, next to her person; he then speaks a plainer language, talks of the congeniulity of minds; and if she ean overlook a wretched body, he does not see why, at last, every sentiment of their hearts might not be in unison and plainly avowed." IIis vanity got the better of his judgment, and there is little doubt but that he presumed too far, and met with a repulse, if not with reproof; hence his rancerous and lasting hate. I find among Mr. Spence's papers a memorandum to the following effect, "Lady Mary W- told Lady Pomfret, that when she became much acquainted with the Duke of Wharton, Mir. I'ope grew jealous, and that oceasioned the breach between them." Mr. Spence ap: pears to have had this from Lady P'omfret herself.-Jervas, in a letter to Pore, which has no date, facetiously hints at the good terms upon which he affected to be with her. - " Lady Mary $\mathrm{W}$ - ordered me, by an express this Wednesday morning, sedente Gayo et ridente Fortescurio, to send you a letter, or some other proper notice, to come to her on Thursday, about five o'cloek, which I suppose she meant in the evening." - His own letters to her contain many hints of his passion and pretensions, indeed the whole of them evidently show that he was then a fervent admirer, though his bosom was afterwards filled with such rancorous hate. -Editur. 
shippers of the Virgin Mary; and, among other things, pray to her for a good trade in their vocation.-The nuns in Spain take very great freedoms: and one of their prayers at the foot of the crucifix is to beg pardon of their sweetest spouse (whose image is on it), if they should happen to add a pair of horns to his head.-Sig. $N$.

Their very bull-feasts are a sort of religious act, as stageplays were among the Romans. They are generally to celebrate their rejoicings on some saint's day, or other great holiday of the church.- They seem almost as fond too of the sanguinary effects of these spectacles, as the Romans were of those in their amphitheatres.-When a bull that has obtained a high character in some former feast has been passing by, I have heard some of the ladies ery out, " $\mathrm{O}$ the dear creature!" and others: "Blessed be the soul of the mother who bore thee; thou hast killed thy six men !" 一Sig. $N$.

Santa Teresa, in one of her exclamations, makes the chief nisery of the damned to consist in their being incapalle of love! - This is the saint, who is so generally represented as fainting away, upon an angel's touching her with a dart tipped with fire.-The Spanish ladies are of a temperament particularly apt to take fire. As they are more confined, they are fuller of passion than other women are; and sometimes actually faint away from a look at a window.-Sig. $N$.

No paintings are so good for prints as those of Guido, from his disposition of the lights and shades.- "Why have you not engraved more of Raphael's designs?"-Because many of his are already done, and others are ill-placed and difficult to come at.-I wanted to have engraved the 
Transfiguration, but when I took a view of it with that design, I found 1 conld not see it enough to do it justice. -Grincomo Freig.

The top of the column, by which they measure the risings of the 'Tiber at Rome, is twenty-two feet above the common surface of the river: and yet the water has risen so high as to hide the very top of the columm.-Ficoroni.

Some of the Greek artists seem not to have likel the sort of Terminal figure used by the Egyptians. There is one in the Montalta gardens at liome, which is as broad at bottom as at top, and I have seen several others of the same kind. This appears to be a Greek Terminus by the inseription, which is:-OEMIETOK $\triangle$ IIC O NAYMAXOC.Mr. T.

The famous forge of Vulean there, is on what seems to have been a tombstone: and is, perhaps, only a common blacksmith's shop after all; for you have a cutler's shop on the opposite side. They are both very neat work, and much better than the poulterer's shop on a marble in one of the gardens just out of the Porta del Popolo.-Mr. T.

The old figure of a gardener in Montalta gardens, has only a loose vest or shirt on, and over that what some call a toga viminalis, or coat of twigs. I don't know how they came to mistake it for such, as it is evidently meant to imitate straps of leather.-Mr. T'.

The three altars, in one of the rooms in the Capitoline Gallery, were found in the port of Nettuno. That with a Neptune in relievo on it, is inscribed, ara neptrix. That with a winged deity flying, ARA ventorvm. And that with a ship sailing gently along, ARA Trangvillitatis.

- An eminent engraver and printseller at Rome. 
They are all three just alike; small, round, and with a rostrum coming out of the front. They are portable enough ; and are supposed to have been earried to sea in their voyages, for the ship's erew to offer sacrifice upon.-Mr.T.

One of the Centaurs in black marble, at the Monte Citorio, has a tiger's skin over his left shoulder, and his hands are tied together with the tail of it. He looks back with pain and dejeetion in his face. There was probably a Cupid behind him originally, and there is the hole in his baek, in which it might have been fixed. Centaurs are thus represented by the ancients, in other monuments, to show that love conquers the roughest monsters. The other Centaur, there, has Baechanalian attributes about him too ; but looks with a much gayer air. The former is represented in years, and this, young. As they are of black marble, and were found in Ifadrian's Villa, it is possible that they were part of the furniture in the first apartment of the Hades, which historians tell us was represented there; and they might have their Bacehanalian attributes, because the secrets of that place were laid open to those who were initiated in the mysteries of Bacchus.-If this conjecture should happen to be true, it might be very well worth while to search further about the spot where these figures were found; beeause there are no statues more searee than those relating to the infernal beings in general.-Mr. T.

The fine old Mosaie picture, of four pigeons drinking out of a bason of giallo antico, is much the finest Mosaic I ever saw of the ancients; and is almost as good as what they do at present at Rome. It is an absolute painting, and the bason is so admirably rounded and hollowed at bottom, that you see quite under the sides of it.-Mr. T. 
The persons who fixed the fine figures, relating to the Story of Niobe and her C'hildren, at the Villa Medici, did not either understand them, or place them so well als they ought to have done.--They seem to have mistaken Amphion for one of the sons ; so that there are but six sons at present, and seven daughters: and the faces of all the figures, in general (exeept two of the sons) are disposed so as to regard the speetator, rather than to follow their proper business in the story: just as one sees bad actors speak rather to the pit, than to one another; or injudicious painters, who make the persons in their pietures regard you, rather than the persons in the piece, with whom they should be wholly concerned.- $M r . T$.

I had this piece of marble from IFadrian's Villa. It was broken from a marble slab, to which it had been originally joined. In the juncture was a leaden medal, with the name of the Emperor Hadraxis Avgrstrs, and a little under it, on the stone itself, this inseription, MaDRIANI Avg. cos. II- $\overline{\mathbf{x}}$ crxxrr. This medal was, no doubt, placed there by IIadrian's order, as prinees now plaee medals in the foundation stone of any great work they undertake, to perpetuate the memory of the founder, even when the work may come to destruetion.-Ficoroni.

The whole rise of the Monte Testaceo, from the villa of the Cavalier Corradini, to the eross on the highest point of it, is upwards of eight hundred fect, and consists of broken piees of earthenware, quite up to the top. About that eross it is a sort of plain, of considerable breadth, all eonsisting of these fragments; sometimes bare, sometimes covered for two or three inches deep with earth. At the bottom, there are excellent vaults almost all round it; in 
which wine is kept extremely well, and eool. The vaults are plastered on the top and sides, exeept on that side next the mountain, which consists wholly of potsherds, without mortar, and with twenty or more round holes in each, to suffer the ingress of the air from the mountain. This convenienee was found out, about a humdred years ago, by the Jews, who spin silk in the valley.-Mr. $T$.

The genius of the Danube, in the first eirele of figures on the Trajan column, holds the beginning of the bridge of boats in his right hand.-In the fourth eirele is a battle, and a deity, like Jupiter, fighting for the Romans.-In the fifth, are several boats, and two Biremi in particular. The larger of the two has but ten oars on a side, which may serve to show the minuteness of the Roman galleys; for one of ten oars on a side, all in one line, would be but a very pitiful galley.-In the sixth eirele there is one soldier supporting another that is wounded; and a third person holding his hand, or feeling his pulse: all their faees are very fine and pathetie, and have a much stronger expression of the several passions, than appears in the prints by Bartoli.In the seventh eircle, is a person embraeing the emperor's knee, and my eye could not well reach any higher.-It might be worth while to compare the prints with the originals, as far as the eye ean reach.- The very first article I have mentioned, though a very significant one, is omitted in the prints.-Mr.T.

Might it not be worth while, for any one who is to stay long at Rome, to make a collection of all the religious inseriptions in the ehurches, and other parts of the city ; and publish them, as Gruter did his old inseriptions? This would show how vast a share of their religion in that holy 
eity, is turned to the Virgin; how little las remained for so many centuries back to our Siviour; and that (iod himself, is almost wholly forgot among them.- $\mathrm{Mr}$. T'.

A nobleman of Naples built a very pretty house to retire to, and enjoy himself in his latter days, at Portici. It was just finished, and the gardens eoming to perfection, when the king lappened to pass by, and like it. The next morning a courtier was sent to the nobleman, to let him know that his majesty had taken a faney to his house. The nobleman was extremely struck with the message, and only said; " if the king likes my house, to be sure he must have it."-Mr. Allen, at Naplss. ['This is the house where all the best of the statues, paintings, and antiquities found in the subterranean eity of IIereulaneum are now kept.spence.]

The country, by the road from Ferrara to Palua, grows more and more cultivated and pleasing, in proportion as you get farther from the ecelesiastical state: and in some of the best parts of it, the cultiration of the fields has a good deal the air of a garden. They leave a level border of eight or ten feet on each side of the cornfields; this is sown with grass, and, after mowing, makes a handsome grass walk all round each field. In some of these the fosses were made like eanals, and the grass walks were formed in easy slopes down to them._. $\mathrm{Nr}$. T T.

If spies are bal people, a great part of the population of Venice must be bad. There are no less than thirtythree thousand pensioned by the state: among which aro all the gondoliers, and a great number of priests and abbés.-Anon.

The eyes are everything.-When some one observed to 
me, that a pieture was like in everything but the eyes; my answer was: " then it is not like at all."--Signora Rosulba, at Venice.

Everything I do seems good to me just after I have done it, and perhaps for seven or eight hours afterwards.Signora $R$. [Though one of the most modest painters of the age. So that the difference between the modest and the sensible artists, and those that are ignorant and impudent, seems to be, that the former ean find out their own faults, and the latter never ean.-Spence.]

I have been so long aecustomed to stndy features, and the expressions of the mind by them, that I know people's tempers by their faces.-Signora $R$. [She added as a proof of this, the eharacters of two of my friends, whom she had seen but twice or thrice, and my own : as justly (and the last perhaps more so) as I could have done myself.-Spence.]

I was always imitative in everything, as far baek as I ean remember. As to painting, in particular, I began with miniature; and it was a good while before I drew any portrait the size of life.-Signora $R$.

That Magdalen is a very fine one! If you observe it, 'tis not only her eyes that cry; she eries all over. (Jusqu'au bout des doigts, were her words.)—Signora $R$.

I pray in German, beeause that language is so energetic and expressive.-Signora $R$.

The German painters are not so genteel, * nor so good as the French.-I have seen but very little of Sir Godfrey

* Si valenthuomini, appears to have been the expression made use of. I am at a loss to know what sense Mr. Spence affixed to the word substituted.-Editor. 
Kneller's.-There is a Mocenigo, done by him here at Venice; that is a very good picee. In speaking of sir Godfrey on another oceasion, she said: "I concluded he could not be religious, because he was not modest."signora $R$.

The country all about Mantua runs all on a flat, and for ten or twelve miles round the eity, the trees are remarkably low aud small. I did not see any such thing as a great beech, pine, or cypress, in all that eompass. There is no such thing as a rock, or a hill, near it. So the face of the country must have been quite ehanged, or Virgil did not take the landseapes, in his Eclogues, from his own country. They are therefore probably either imaginary, or taken from the Greek writers he imitated, or from some other parts of Italy_- $\mathrm{Mr}$. T .

Men are a sort of moving plants ; and, like trees, reeeive a great part of their nourishment from the air.-You were observing the other day how sickly that row of trees in the Thuilleries looked, from being pent up between the terrace and the wall. It is just the same with men who keep too much at home: and it is for the same reason that women, in general, who keep more within doors than men, are more unhealthy.-Mons. Le Grand, at Paris.

A lady, who came out of the country this summer, to see the Court at Versailles; on her return said: " bating the amours that reign there, I never saw so dull a thing." [Outre la passion, je n'ai jamais vu de chose plus triste.] - II. Le G.

I verily believe that the vices of the nineteen young people in twenty, are more out of vanity than inclination; at least I am sure it was so with me when I was young.- 
Our greatest fault, when we are joung, is, that we think we shall never be old.-Lord $C$.

They have made my Hidalgo a Lord in the English translation of Gil Blas, and a Burgomaster in the Dutch. I verily believe that people are much alike in all countries : one ean't paint one, without painting a thousand.-Mons. Le Sage, at Paris.

Speaking of his Git Blas, and Diable Boiteux, he said: "Ay, those were the two first works that ever I risked into the world." ("Ces sont mes enfans perdus.")—“ It was in this room that I wrote nost of Gil Blas." - Mr. Le S. [And an extreme pretty p]ace to write in it was.-- His house is at Paris in the Faubourg St. Jaques; and so, open to the country air: the garden laid out in the prettiest manner that ever I saw, for a town garden. It was as pretty as it was small, and when he was in the study-part of it, he was quite retired from the noise of the street, or any interruptions from lis own family. The garden was only of the breadth of the house, from which you stept out into a raised square parterre, planted with a variety of the ehoiecst flowers. From this, you went down, by a fliglit of steps on each side, into a Berceau; whieh led to two rooms or summer-houses quite at the end of the garden. These were joined by an open portieo, the roof of which was supported with eolumns; so that he eould walk from the one to the other all under cover, in the intervals of writing. The bereeaux were covered with vines and honeysuekles, and the space between them was grove-work. It was in the right-hand room as you go down that he wrote Gil Blas.-Spence.]

Monsieur Le Sage lives in a pretty genteel manner, though he has little more now to live on, than what his son 
Montmenil gets by the stuge. IIe is the best of sons, and they live together in the greatest harmony. * - Albe Colvit. [I heard le sage say, "I thank Crod, I don't wish for any one thing that I could not pray for aloud."-Montmenil is the best actor in Framee, for plain, easy, gented comely ; when he was upon the stage he did and said everything so naturally, that he sermed the very person he represented; and one almost forgot that he was upon a stage. Although so exeellent an aetor, the Abbe sail, that he did not get above a hundred Louis d'ors a year by his protession.Spence.]

Someboly had been teseribing the perpetual complaints of the people in England, in spite of all their privileges and enjoyments.-" Surely, (said Le Sage,) the people of Englind are the most mhappy people on the face of the earth,-with liberty, property, and three meats a day."

"Ifolland would be a good country to live in,-if you could only change the four elements and the people."-Le Sage. [If one considers that the land there is generally marshy, the waters stagnant, the air offensive; and that

- There is something very interesting in these little details of the peaceful and simple habitation of the admirable author of Gil Blas, a work only second to that of Cerrantes. - It is a painful reflection, that the pecuniary emoluments of Le Sage were so trifling as not to enable him to secure a moderate independency in his old age, althongh his writings were numeruus and snccessful. He however lived to enjoy his fame, in calm and philosophic retirement. How this contrasts with the rewards now bestowed on the successful adventurer in the same field!-the price of a single popular novel in our days, would have been to him, with such moderate desires, an ample e mpetence. He died in $174 i$, after having been aftlicted with total cica lness for ten years. - Euitor. 
peat is mostly used for firing:- one must allow that what is said of the elements, eomes near the truth.-spence.]

Horace, in his deseription of the Fortunate Islands, * says a great many things which agree with England: and had not he mixed his Italian trees, and some few other Italian ideas with it, (as everybody forms their notions of countries they have not seen from countries they have seen,) the whole might have passed almost for a description of our island.-Mr. T.

Dean Berkley $\uparrow$ used to apply the same deseription to

* Epod. xvi. 41-63.

+ The fullowing interesting notice of this amiable enthusiast, nceurs in a letter of Swift to Lord Carteret. "There is a gentleman of this kingdom just gone for England; it is Dr. George Berkley, Dean of Derry. He takes the Bath in his way to London, and will of course attend your excellency : and perhaps you may not be ill entertained with some account of the man and his errand. He was fellow of the university here, and going to England very young, about thirteen years ago, he became the founder of a sect there called the Immuterialists, by the force of a very curious book upon that sul ject. Dr. Smalrilge, and many other eminent persons, were his proselytes. I sent him, secretary and chaplain, to Sicily, with my Lord Peterborongh, and upon his Lordship's return, Dr. Berkley spent above seven years in travelling over most parts of Europe, but chiefly through every corner of Italy, Sicily, and other islands. When he came back to England, he found so many friends that he was effectually recommended to the Duke of Grafton, by whom he was lately made Dean of Derry. Your excellency will be frightened when I tell you all this is but an introduction; and I must now mention his errand. He is an absolute philosopher with regard to money, titles, and power, and for three years past, has been struck with a notion of founding an university at Bermudas, by a charter from the crown. He has seduced several of the hopefullest young clergymen and others here, many of them well provided for, and all in the fair way of preferment: but in England his conquests are greater, and I doubt 
Bermuda, and his seheme of going thither; and was so fond of this Epode on that aceount, that he grot Mr. Pope to translate it into English, and 1 have seen the translation. - Mr. L. A.

will spread very far this winter. He showed me a little tract which he designs to pullishl, and there your exeellency will see his whole scheme of a lifs arademieo-philosiphical (I shall make you remember what you were), of a college founded fin ludian seluolars and missionaries, where he most exurbituntly proposes a whole hundred pounds a year for himself, forty pounds fior a fellow, and ten fur a stmlent. Ilis heart will break if his deanery be not taken from him, and left to your excellency's disposal. I discouraged him by the coldness of courts and ministers, who will interpret all this as impossible, and a vision, but nothing will flo: and there. fore, I to humbly entreat your excellency either to use such persuasions as will keep one of the first men in the kingdom fur learning and virtue quiet at home, ur assist him by your eredit to compass his romantic design; which, however, is very noble and generous, and directly proper for a great person of your excellent education to encourage."-J)r. Warton, says, Lord Bathurst told him, " that all the members of the Scriblerus (dul, being met at his house at diuner, they agreed to rally Berkley, who was also his guest, on his scheme at Bermudas. - Berkley having listened to all the lively things they had to say, begged to be heard in his turn; and displayed his plan with such an astonishing and animated furce of elexpuence and enthusiasm, that they were struck dumb, and after some pause, ru se up all tugether with earnestness, exclaiming - "I.et us all set vut with him immediately." - After three years residence, and the utmust perseverance, he was obliged to abandon his project at the Burmudas, finding his plan impracticable, from the want of the promisel support of government.-The following elegant puetical effusion, written when he was preparing for his expedition, contains a prophecy which is now, probably, fast hastening to fultilment.

The Muse, disgnsted at an age and clime

Barren of every ghorious theme,

In distant lands now waits a better time, l'rodueing subjects worthy fame: 
In happy climes, where from the genial sun And virgin earth such scenes ensue:

The force of art by nature seems outdone, And fancied beauties by the true:

In happy climes, the seat of innocence, Where nature guides, and virtue rules;

Where men shall not impose for truth and sense, The pedantry of courts and schools.

There shall be sung another golden age, The rise of empire and of arts;

The good and great inspiring epic rage, The wisest heads and noblest hearts.

Not such as Europe breeds in her decay, Such as she bred when fresh and young, When heavenly flame did animate her clay, By future poets shall be sung.

Westward the course of empire takes its way: The four first acts already past,

$\Lambda$ fifth shall close the drama with the day: Time's noblest offspring is the last.

Editor. 


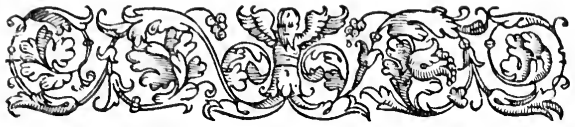

\section{SPENCE'S ANECDOTES.}

SECTION VII. 1742-43.

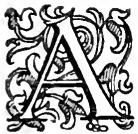

LITTLE after Dr. Young had published his Universal Passion, the Duke of Wharton made him a present of two thousand pounds for it.-When a friend of the Duke's, who was surprised at the largeness of the present, cried out on hearing it: "What! two thousand pounds for a Poem?" The Duke smiled, and said; "It was the best bargain he ever made in lis life, for it was fairly worth four thousand." Mr. Rawlinson.

When the Doctor was deeply engaged in writing one of his tragedies, that nobleman made him a very different kind of present.-He procured a human skull, fixed a candle in it, and gave it to the doctor as the most proper lamp for him to write tragedy by. $-R$.

The sale of a book may be burt a great deal, by an illehosen title.-Dr. Cheyne's bookseller absolutely refused to print his book on Health, unless he would change the title, the original one designed for it was, " A Treatise on Sanity and Longevity."-Mr. Hooke. 
The side Oratories at St. Paul's were added to Sir Christopher Wren's original design, by order of the Duke of York: who was willing to have them ready for the popish service; when there should be oceasion.-It narrowed the building, and broke in very much upon the beanty of the design. Sir Christopher insisted so strongly on the prejudice they would be of, that he aetually shed some tears in speaking of it; but it was all in vain. The duke absolutely insisted upon their being inserted, and he was obliged to eomply.-Mr. Harding.

Rollin has written a letter very full of compliments to Dr. Swift.— " Has not he affronted him by it?"'-No:the doetor does not hate praise, he only dislikes it when 'tis extravagant or coarse.-When $\mathrm{B}$ him more than all his friends and relations; the dean made him no manner of answer; but said afterwards; " the man's a fool !"-I once said to him ; "There's a lady, doetor, that longs to see you, and admires you above all things."_ "Then I despise her heartily !" said he.- $\mathrm{Mr}$. Pope.

When I had filled up this Epistle, begun by Swift, I sent it to him, and thought I had hit his style exactly; for it was familiar, lively, and with odd rhymes.-The doctor had a very different opinion of it; and did not think it at all a right imitation of his style.- $-P$.

When somebody was speaking to Mr. Addison, of Budgel's Epilogue to the Distressed Mother, and said they wondered how so silly a fellow could blunder upon so good a thing:-Addison said, " $\mathrm{Oh}$, sir, it was quite another thing when first it was brought to me !'- $P$.

Addison seemed to value himself more upon his poetry, 
than upon his prose; though he wrote the latter with such particular ease, flueney, amil happiness. $-P$.

The Duke of Buekingham was superfieial in everything; even in poetry, whieh was his fort.- $P$.

Rowe was bred first at Westminster, and then at the Temple. He had about three hundred pounds a year, and his chambers there. His father was a Sergeant at Law.He was of a eomely personage, and a very pretty sort of nan.*-Mr. Levis.

- Besides his patrimony, Rowe enjoyed in the latter part of his life several luerative oftices. When the Duke of Queensbury was Seeretary of State, he made Rowe his L'nder Seeretary, but at the death of the duke he retired. $\mathrm{U}_{\text {pon }}$ the accession of George the First, he had a place given him in the Customs, and was made pret-laureate. - Besides these the Prince of Wales conferred on him the place of Clerk of his Couneil; and the Lord Chaneellur, Parker, made him his Secretary for the Presentations. His voice was uneommonly sweet, his observations so lively, and his manners so engaging, that his friends delighted in his conversation. He died much regretted at the age of forty-five, in 1718. He was twice married, and left a son by his first wife, and a daughter by his seeond.-Dr. Welwood prefixed some brief memoirs of him to the posthumous publication of his translation of Luean's Pharsalia. -The following aecount probably rests upon the authority of Warburton, as it is well known he supplied the materials and corrected the sheets of liuffhead's Life of l'ope, from whenee I transcribe it. "Rowe, in the opinion of Mrr. Pope, maintained a decent character, but had no heart. MIr. Addison was justly offended with him for some behaviour whieh arose from that want, and estranged himself from him; which Rowe felt very severely. Mr. Pope, their common friend, knowing this, took an opportunity, at some juncture of $\mathrm{Mr}$. Addison's adraneement, to teil him poor Rowe was grieved at his displeasure, and what satisfaction he expressed at his good furtune; which he expressed so naturally, that he could not but think him sincere. Addison replied, I do not suspect that he feigned; but the levity of his heart is such, that 
The first part of Robinson Crusoe is very good.-De Foe wrote a vast many things; and none bad, though none excellent, except this. There is something good in all he has written. $-P$.

Mr. Pope was born on the 21st day of May, 1658.-His first edueation was extremely loose and disconcerted. He began to learn Latin and Greek together (as is enstomary in the schools of the Jesuits, and which he seemed to think a good way) under Banister their family priest, whom, he said, was hing abont two years ago at Sir Harry Tichburne's.-He then learned his accidence at 'Twiford, where he wrote a satire on some faults of his master.-He was then, a little while, at Mr. Dean's seminary at Marylebone; and sometime under the same, after he removed to Hyde Park Corner.-After this, he taught himself both Greek and Latin.- " I did not follow the grammar; but rather hunted in the authors, for a syntax of my own: and then began translating any parts that pleased me particularly, in the best Greek and Latin poets: and by that means formed my taste; which, I think, verily, about sixteen, was very near as good as it is now." $-P$.

I should certainly have written an Epic Poem, if I had not engaged in the translation of Ifomer. $-P$.

All the rules of gardening are reducible to three heads: - the contrasts, the management of surprises, and the concealment of the bounds.- " Pray, what is it you mean by he is struck with any new adventure, and it would affect him just in the same manner if he heard I was going to be hanged.-Mr. Pope said, he could not deny but that Mr. Addison understood Rowe well."-Mr. Bowle, in his edition of Pope's Works, has erroneously supposed that this note was taken by Dr. Warton from Spence's Anecdotes.-Editor. 
the contrasts?"-The disposition of the lights and shades. —" "I'is the colouring then."-Just that._- Should not variety be one of the rules?"-C 'ertainly; one of the chicf: but that is inchuded mostly in the contrasts.-I have expressed them all, in two verses; (after my mamer, in very little compass, which are an initation of Horace's Omne tulit punitum, \&sc.

"Ile gains all ends, who pleasing confounds, Surprises, varies, and conecals the bounds."

Pope.

I always was particularly struck with that passage in Homer, where he makes Priam's grief for the loss of Hector, break out into anger against his attendants and sons : and could never read it without weeping for the distress of that unfortunate old prince. $-P . \quad[$ He read it then; and was interrupted by his tears.-Spence.]

I have often seen him weep, in reading very tender and melancholy passages._- Wrs. Blount.

Dryden lived in Gerrard Street, and used most eommonly to write in the ground-room next the street.*-Pope.

[Dryden was not a very genteel man, he was intimate with none but poetical men.-He was said to be a very good man, by all that knew him; he was as phump as Mr. Pitt; of a fresh colour, and a down look, and not very eonversible.-P. [Addition from Papers.]

Dryden had three or four sons; John, Erasmus, Charles, and perhaps another. One of them was a priest, and an-

+ " His house," says Mr. Malone, " (for why should it not be as precisely ascertained as the various places of Milton's residence?) was the fifth on the left hand in coming from little Newport Street, and is now numbered 43. Behind, his apartments looked into the gardens of Leicester House."-Malone. 
other a captain in the Pope's guards.*-He left his family estate, which was about one hundred and twenty pounds a year, to Charles.-The Historiographer's and Poet Laureate's places were worth about three hundred pounds a year to him.t-P.

Dryden cleared every way about twelve hundred pounds by his Virgil; and had sixpence each line for his Fables. -For some time he wrote a play, at least every year; but in those days ten broad pieces was the usual highest price for a play: and if they got fifty pounds more in the acting, it was reckoned very well.+-His Virgil was one of the

* " Pope was deceived by the circumstance of the younger son having two Christian names; for Dryden certainly had but three sons. Mrs. Thomas probably led him into another error, that one of them was a priest; for this conversation passed in 1736, some years after her spurious narrative (respecting Dryden's Funeral) was published. The other part of this information was correct; for Erasmus Henry was certainly a eaptain, and probably in the Pope's guards."-Malone.

† These anecdotes of Dryden have been so fully investigated and illustrated by Mr. Malone, in the Life prefixed to his edition of Dryden's Prose Works, that I shall make one general reference to that source of information, for the correction of some little inaccuracies; eiting the passages in notes. Mr. Malone made a careful transcript of the Duke of Newcastle's manuscript copy of these anecdotes, for his own use, arranging them under distinct heads._Editor._-" Dryden made no will, and as his son Charles died in his mother's lifetime, he had never more than forty pounds a year to live on.-He was deprived of both his places in 1689, and his certain revenue was then reduced to one hundred and twenty pounds a year." $-M$.

$\ddagger$ " Dryden received thirty guineas for the copyright of Cleomenes. - The case, however, might br, as stated, in part of Charles the Second's time; but afterwards a larger sum was given; and in the middle of the reign of Queen Anne the common price of the copyright of a play was fifty pounds." $-M$. 
first books that had anything of a subseription; (and even that was a good deal on aecount of the prints, which were from Ogilby's plates touehed up:) as the Tatlers were the first great subseription.

It was Dryden who made Will's Coffee-house* the great resort for the wits of his time. After his deatl, $\Lambda$ ddison transferred it to Button's ; who hat been a servant of his: they were opposite each other, in Russell street, Covent Garden.-P.

Lord Bolingbroke's usual toast after dinner is: " to Friendship and Liberty." -1 should like to have it for a motto to my door, with an $\mathrm{S}$ added after it (AMicitie ET Libertati s.) $-P$.

On our letting the French and Spanish flects eseape, off Toulon; Mr. Pope said: "They have lost the only oppor-

- This house was kept by William Urwin, and was situated on the north side of Russell Street, at the end of Bow Street; it is now occupied by a perfumer, and numbered 23.-Here Dryden had his armed chair, which in winter had a settled and prescrip. tive place by the fire, was in the summer placed in the balcony ; and he called the two places his winter and his summer seat. The appeal was made to him upon any literary dispute. The company assembled on the first or dining-room floor, as it was called in the last century, and hence we hear of a balcony. The company did not sit in boxes, as at present, but at various tables which were dispersed through the room. Smoking was permitted in the public room; it was then so much in vogue that it does not seem to have been considered a nuisance. Here, as in other similar places of meeting, the visitors divided themselves into parties; and we are told by Ward, that the young beaux and wits, who seldom approached the principal table, thought it a great honour to have a pinch ont of Jryden's snuff-box. Will's continued to be the resort of the wits at least till 1710. Probably Addison established his servant (Button) in a new house about 1712; and his fame, after the production of Cato, drew many of the Whigs thither. $-M$. 
tunity they have ever had! Now we may be a province to France in ten years."

[Speaking of the making of corrupt members of parliament the chief wheel in government, he said: " It will never hold: it may last our time, but our posterity must be totally undone, if we are not. Look into other states, and see how they have fallen round about us; the same cause will produce the same effects: and God will hardly go ont of his way, for the first time, in favouring us." * P. [Addition from Papers.]

If I may judge myself, I think the travelling Governor's Speech one of the best things in my new editions to the Dunciad. $-P$. [This was said a little before the fourth book of that poem was published._Spence.]

Those two lines on Alsop and Freind have more of satire than of compliment in them :

Let Freind affect to speak as Terence spoke, And Alsop never but like Horace joke ;-

Dunciad, iv. 224.

though I find they are generally mistaken for the latter only. They go on Horace's old method of telling a friend some less fault, while you are commending him ; and which indeed is the best time of doing so.-I scarce meet with anybody that understands delicacy. $-P$.

When I was looking on his foul copy of the Iliad, and observing how very much it was corrected and interlined,

* Pope, as well as his friend Swift, was a Whig, according to the then acceptation of the term. His principles, as delineated in his poems, are almost republican; for he explodes,

" Th' enormous faith of many made for one."

We have here the language of the advocates for reform in our own times.-Editor. 
he said, "I believe you would find, upon examination, that those parts which lave been the most eorreeted read the easiest." -1 . [I read only the first page, in which

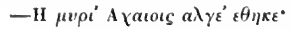

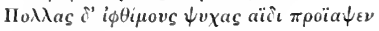

Hoivev

was thus translated,

That strow'd with warriors dead the Phrygian plain,

And peopled the dark shades with heroes slain.

It now stands thus,

That wrath which hurl'd to Pluto's gloomy reign

The souls of mighty ehiefs untimely slain.

And was evidently altered to preserve the sense of the word $\pi$ foí $\psi \varepsilon v$. What a useful study might it be for a poet, to eompare in those parts what was written first, with the successive alterations; to learn his turns, and arts in versifieation; and to consider the reasons why such and such an alteration was made.*-Spence.]

My works are now all well laid out. The first division of them contains all that I wrote under twenty-six ; which may be called my Jurenilia._-The second; my translations from different authors, under the same period.-The third; my own works since.-And the fourth; my Translations and Imitations. $-P$.

I was first forcel to print in a small form, by other

* The MS. of the Iliad descended from Lord Bolingbroke to Mallet, and is now to be found in the British Museum, where it was deposited at the pressing instance of Dr. Maty. Mr. D'Israeli, in the first edition of his Curiosities of Literature, has exhibited a facsimile of one of the pages. It is written upon the backs and covers of letters and other fragments of papers, evincing that it was not without reason he was called Paper-sparing Pope.-Editor. 
printers beginning to do so from my folios.**-I will have no more to do with printing, myself: and if the world should have a mind to a good edition of all my works, it must be from somebody that may take care of it, after my death. $-P$.

'Tis most eertain that nobody ever loved money so little as my brother.-Mrs. Racket, speaking of Mr. Pope.

The aceident of the eow, was when my brother was about three years old. He was then filling a little eart with stones. The eow struek at him; earried off his hat and feather with her horns, and flung him down on the heap of stones he had been playing with. In the fall he eut himself against one of them, in his neek near the throat. -The other aecident of his being like to be killed, when he was overturned in the eoaeh and six, was in the water just before you eome to Twickenham.-NIrs. $R$. [Rather somewhere the Hounslow Heath way, for he was coming home from Dawley.-Mirs. Blount.]

I believe nobody ever studied so hard as my brother did, in his youth.- He did nothing else but write and read.Mrs. $R$.

My brother does not seem to know what fear is. When some of the people that he had put into his Duneiad, were so much enraged against him, and threatened him so highly: he loved to walk out alone, and particularly went often to Mr. Fortesene's at Richmond. Only he would take Bounee† with him; and for some time earried pistols in his poeket.

- After which all the large lay on my hands, and I have lost two or three hundred pounds by it.-P. [Addition from Papers.]

$\dagger$ Bounce was a great faithful Danish dog belonging to Mr. Pope.-Spence. 
He used then to say, when we talked to him abont it; that with pistols the least man in lingland was above a mateh for the largest._MIrs. R. [Ifter the first celition of the Dunciad, and while Mr. Pope was preparing another yet more intitating; I took the opportunity one morning, when I had been reading some things to him out of Bailey's Dietionary, in his study, to turn to the article Bruschius, a poet of Bohemia: who, when he wats going to publish a satire against some of the blockheads of that eountry, was waylaid in a wood, and murdered by them. Something of the same nature had been hinted at, as to IIam-walk. I read the article to Mr. Pope, and said some things, that I thought my friendship obliged me to say, about his venturing so often to Richmond alone.-He said that the people I mentioned were low aud vile enough, perhaps, to be capable of such designs; but that he should not go a step out of his way for them; for let the very worst, that I could imagine, happen; he thought it better to die, than to live in fear of such raseals._Spence.]

When my brother's faithful dog, and eompanion in these walks, died; he had some thoughts of burying him in his garden, and putting a piece of marble over lis grave, with the epitaph; o Rare bounce! and he would have done it, I believe, had not he apprehended that some people might take it to have been meant as a ridicule of Ben Jonson.Mirs. $R$.

Shakespeare, in his frequent journeys between London and his native place, Stratford-upon-Avon, used to lie at Davenant's, the Crown, in Oxford. He was very well acquainted with Mrs. Davenant; and her son, (afterwards Sir William,) was supposed to be more nearly related to 
him, than as a godson only.-One day when Shakespeare was just arrived, and the boy sent for from school to him. a head of one of the colleges, (who was pretty well acquainted with the affairs of the family,) met the child running home, and asked him, whither be was going in so much haste? The boy said : " to my Godfather Shakespeare."- "Fie, child, (says the old gentleman,) why are you so superfluous? have you not learned yet that you should not use the name of God in vain." $-P$.

Mr. Pope was tanght his accidence and the Greek alphabet, by a priest in the family:-was sent to school, at Twiford, when he was about eight; stayed there only one year: and at the other little schools till twelve years old."When I came from the last of them, all the acquisition I had made, was to be able to construe a little of 'Tully's Offices." $-P$.

My next period was in Windsor Forest, where I sat down with an earnest desire of reading; and applied as constantly as I possibly could to it, for some years. I was between twelve and thirteen, when I first went thither, and continued in this close pursuit of pleasure and languages, till nineteen or twenty.-Considering how very little I had, when I came from school, I think I may be said to have taught myself Latin, as well as French* or Greek; and in all three my chief way of getting them was by translation. $-P$.

* That Pope understood French sufficiently to read it and relish their poetry, there can be little doubt; yet Voltaire says: "Pope, whom I was intimately acquainted with, could hardly read French; and spoke not one syllable of our language, not being capable of doing it." He was not more exact, it appears, in his knowledge of Greek.-Editor. 
I wrote the Essay on ('riticism, two or three years before it was printed.- $P$ ?

In translating hoth the Iliad and the Odyssey my usual method was, to take advantage of the first heat; and the'n to correct each beok, first ly the original text, then by other translations: and lastly to give it a reading for the versifieation only.- $T$. [1 low much he has correeted, and in what manner, may be seen by the original manuseripts of each: whieh are bound up; that of the lliad in two volumes, and that of the Odyssey in one.-From the MS. of the latter, it appears how truly he says; " that he translated twelve books of it."- That volume contains the first draught of the third, fifth, seventh, and ninth books: part of the tenth ; from, " now dropt our anchors in the ocean bay." verse 157 to the end.- The thirteenth and fourteenth-part of the fifteenth, from " meantime the king Eumreus and the rest," vers 321 to the end-and the seventeenth, twentyfirst, twenty-seeond. and twenty-fourth, that is ten books entire, and part of two others, which, with his great eorreetions in Broome's part (without reckoning some manuseript of his own, which is lost), would make up the compass of twelve books at least._Spence.]

I am inclined to believe, that we may probably have passed through states of being before this, though we are not now eonseious of our having past through them: and may possibly pass through other stages, without being eonscious of this. $-\mathrm{A}$ ehild does not know the design of his parents, and may thiuk them severe. while they are only endearouring to do him good; till he is fourteen or fifteen, or perhaps till he is four or five-and-twenty. - It may be thus with us, and our great parent: and we may pass 
through as many different stages of being, as they do through years, before we come to the full opening of our understanding. $-P$.

Some wonder why I did not take in the fall of man, in my Essay; and others how the immortality of the soul came to be onitted. The reason is plain : they both lay out of my subject, which was only to consider man as he is ; in his present state, not in his past or future.* $-P$.

Some of Plato's and Cicero's reasonings on the inmortality of the soul, are very foolish; but the latter's less so than the former's. - Without revelation, it certainly is a grand peut-être.- $P$.

There was not any one honest minister in all the reigns of the Stuarts ; except Lord Clarendon,-yes Lord Godolphin,-he was a good man; though he had underhand dealings with the Pretender at first. $-P$.

The great thing toward speaking or writing well, is to understand the thing perfectiy, which one is to write or speak about. I scarce ever heard any one speak ill in the House of Commons, in an affair which he was well acquainted with. $-M r . L$.

"I pity you, sir, becanse you have now eompleted everything belonging to your garden." __ W Wy, I really shall be at a loss for the diversion I used to take in laying ont and finishing things. I have now nothing left me to do, but to add a little ornament or two, at the line to the Thames.- $P$. [His design for this was to have a swan, as flying into the river, on each side of the landing-place;

* Ramsay, and some others, in letters sent him about that time - and some of the Popish priests. - Spence. 
then the statues of two river gods, redined on the bank between them and the corner seats or temples; with

"Hic placido fluit amne Meles,"

on one of their urns : and

"Mranis ubi flexibus errat MIincius,_-"

on the other. Then two terms, in the first niehes in the grove work on the sides, with the busts of Ilomer and Virgil; and higher, two others, with those of Mareus Aurelius, and of ('icero.]

“Whenee is that verse on the river Meles?"-In Politian's best poem, his Ambra.-P. [Ife had read Politian when he was very young; and then marked down this for the best of his piees. To anything that pleased him partieularly, he used then to affix this mark $\mathrm{N}$; and before the Ambra, in his Politian, he had added, "Optimum hoc, ut puto, Politiuni opus est." IIe still retained the same opinion of it; though the Ambra seems to be more in Claudian's manner, than some other piees by the same author, and particularly than his Nutritia: and, I should imagine, is not so good as that. There were some few marks beside of a mistaken taste in Mr. Pope, from that early and unguided reading of his. He met with Statius very early; liked him much; and translated a good deal from him: and to the last, he used to eall him the best of all the Latin epie poets after Virgil. However, these two instanees, and perhaps a little more regard for Ovid's Netamorphosis than he might otherwise have had, are the only instanees I ean recollect of this kind : and how soon after his first setting out, he must have formed a most excellent taste who could write so just and admirable a poem as the Essay on Critieism, before he was twenty !-Spence.] 
At this day, as mueh company as I have kept, and as much as I love it, I love reading better. I would rather be employed in reading, than in the most agreeable conversation.- $P$.

"I was just going to ask you a very foolish question;What should one read for?" —_ For!-why to know faets:-but I should read in a quite different manner now, from what I did when I had my great early fit of reading, (from about fourteen to twenty-one.) Then it was only for the diversion of the story; now it should be to make myself and others better.-I would mark down :- on such an occasion, the people concerned proeeeded in such a manner; it was evidently wrong, and had a very ill effect; a statesman, therefore, should avoid it, in a like ease.-Sueh an one did good, or got an honest reputation, by such an action: I would mark it down, in order to imitate it, where I had an opportunity. $-P$.

"Did you never mind what your angry erities published against you?"-Never mueh :- - only one or two things, at first.-When I heard, for the first time, that Dennis had written against me, it gave me some pain : but it was quite over as soon as I eame to look into his book, and found he was in such a passion.- $P$.

When I was looking over some things I had brought from Italy, to piek out what might be of use in his grotto; and eame, among the rest, to some beads and medals that had been blessed at Loretto: he laid them gently aside, and said: " those would be good presents for a papist." $-P$.

Arehbishop Tillotson was very well acquainted with Betterton; and eontinued that aequaintanee, even after he 
was in that high station. One day, when Betterten came to see him at Lambeth, the prelate asked him; " low it came about, that after he had made the most moring discourse that he could, was touehed deeply with it himself, and spoke it ns feelingly as he was able; yet he conld never more people in the ehureb, near so much as the other did on the stage?"- -That, says Betterton, I think, is easy to be accounted for: it is beeanse you are only telling them a story, and I am showing them faets. $-P$.

I began writing verses of my own invention, farther back than I can well remember.-Ogilby's translation of Homer was one of the first large poems that ever Mr. Pope read; and he still spoke of the pleasure it then gave him, with a sort of rapture, only in reflecting on it._-" It was that great edition with pietures, I was then about eight years old. This led me to Sandy's Ovid, which I liked extremely; and so I did a translation of part of Statius, by some very bad hand."- $P$.

When I was about twelve, I wrote a kind of play, which I got to be aeted by my schoolfellows. It was a number of spceehes from the Iliad ; tacked together with rerses of my own.-The epie poem which I begun a little after I was twelve, was Aleander, prinee of Rhodes: there was an under-water seene in the first book, it was in the Arehipelago.-I wrote four books toward it, of about a thousand verses each; and had the copy by me, till I burnt it, by the advice of the Bishop of Rochester, a little before he went abroad. $-P$.

I endeavoured, (said he, smiling,) in this poem, to colleet all the beauties of the great epic writers into one piece: there was Milton's style in one part, and Cowley's in another; 
here the style of Spenser imitated, and there of Statius; here Homer and Virgil, and there Ovid and Claudian.-" It was an imitative poem then, as your other exercises were imitations of this or that story?"'-Just that. $-P$.

Mr. Pope wrote verses imitative of sounds so early as in this epic poem :-

"Shields, helms, and swords all jangle as they hang,

And sound formidinous with angry clang."

Was a couplet of this nature in it ?-There were also some couplets in it which I have since inserted in some of $\mathrm{my}$ other poems, without any alteration. As in the Essay on Criticism :-

"Whose honours with increase of ages grow;

As streams roll down enlarging as they flow."

Another couplet, inserted in the Dunciad already mentioned, * and I think he said the same of that simile:-

"As clocks to weight their nimble motion owe;

The wheels above org'd by the load below."

In the scattered lessons I used to set myself, about that time, I translated above a quarter of the Metamorphoses, and that part of Statius which was afterwards printed with he corrections of $\mathrm{W}$ alsh.- $P$.

My next work, after my Epic, was my Pastorals; so that I did exactly what Virgil says of himself :-

Cum canerem reges et prolia, Cynthius aurem Vellit, et admonuit; pastorem, Tityre, pingues Pascere oportet oves; deductum dicere carmell.

Eclog. vi. 3.-P.

I translated Tully's piece de Senectute, in this early period, and there is a copy of it in Lord Oxford's library.- $P$.

- See ante, p. 19. 
My first taking to initating was not out of vanity, but humility: I saw how defective my own things were; and endeavoured to mend my manner, by copying good strokes: from others, $-P$.

I have often mentioned my great reading period to you. -In it, I went through all the best erities; * almost all the English. French, and Latin poets, of any name: the minor poets, Iomer, and some of the greater Greek poets, in the original: and Tasso and Lriosto in translations-I even then liked Tasso better than Ariosto, as I do still; and Statius of all the Latin poets, by much, next to Virgil.-P?

My epie was about two years in hand, (from thirteen to fifteen.) - Alcander was a prinee, driven from his throne by Deucalion, father of Ninos, and some other princes.-It was better planned than Blackmore's Prince Arthur; but as slavish an imitation of the ancients.-Aleander showed all the virtue of suffering, like Clysses; and of courage, like Eneas, or Achilles.-Apollo, as the patron of Rhodes, was his great defender; and Cybele, as the patroness of Deucalion and Crete, his great enemy. She raises a storm against him in the first book, as Juno does against Eneas ; and he is cast away and swims ashore, just as Llysses does to the island of Pheacia.- $P$.

Mr. Pope thought himself the better, in some respects, for not having had a regular education.-He, (as he observed in particular, ) read originally for the sense; whereas we are tanght, for so many years, to reat only for words. $-P$.

As I hat a rast memory, and was sickly, and so full of application; had I chanced to have been of the religion of

* This probably led him to writing his Essay on Criticism at that period.-Spence. 
the country I was born in, and bred at the usual places of education, I should, probably, have written something on that subject, and against the methods now used there; and, I bekeve, I might have been more useful that way than any other. $-P$.

Bacon and Locke did not follow the common paths, but beat out new ones; and you sec what good they have done: but much more is wanting.-Aldrich did a great deal of good too, in his way; there should be such people in the universities: but nothing can be done effectually, till the government takes it in hand to encourage and animate such a reformation. $-P$.

About fifteen, I got acquainted with Mr. Walsh. He used to encourage me much, and used to tell me, that there was one way left of excelling: for though we had several great poets, we never had any one great poet that was correct; and he desired me to make that my study and aim.-P. [This, I suppose, first led Mr. Pope to turn his lines over and over again so often, which he continued to do till the last; and did it with surprising facility.-Spence.]

Ilearned versification wholly from Dryden's works; who had improved it much beyond any of our former poets; and would, probably, have brought it to its perfection, had not he been unhappily obliged to write so often in haste. $-P$.

Dryden always uses proper language; lively, natural, and fitted to the subject. It is scarce ever too high, or too low ; never, perhaps, except in his plays.- $P$.

Lord Dorset's things are all excellent in their way ; for one should consider his pieces as a sort of epigrams: wit was his talent.- He and Lord Rochester should be considered as boliday-writers; as gentlemen that diverted 
themselves now and then with poetry, rather than as poets. $-P$. [This was said kindly of them; rather to excuse their defects, than to lessen their dharacters.-Spence.]

Rochester has very bad rersification sometimes. $-P$. [ He instanced this from his translation of the tenth satire of Hornee: his full rhymes, de.-spence.]

There is no one of our poets of that elass, that was more judieious than Sir John Denham.-P. [At the end of his Cooper's IIill (edition of 1709), Mr. Pope had written the following note.- "This poem was first printed without the author's name, in 1643 . In that edition a great number of verses are to be found, since entirely omitted ; $*$ and very many others, since corrected and improved. Some few, the author afterwards added: and in particular the four celebrated lines on the Thames,

$$
\text { "O could I flow like thee," \&c. }
$$

* Though it might be a very useful lesson for a poet, to compare those two editions more exactly ; and to consider at each alteration, how and why it was altered: it may not be amiss to subjoin here, the following list of alterations in the poem.-Spence.

Edition, 1709.-Verse 12; more boundless, \&c.-seven verses added instead of two bad ones.-V. 24-26; six rerses only, instead of fourteen not near so good.-V.30-38; were scattered among others far inferior.-V. 40 ; four verses omitted, in which he had eompared Windsor Castle to a big-bellied woman! $-V$. $41-48$; altered for the better.-V. 55-58; ditto, ditto.-V.7782 ; six verses, instead of eight inferior.-V. 86 ; two versesomitted. -V. 100-115; fifteen verses, instead of twenty-six far inferior. -V.121; improved.-V.127-132; altered mueh for the better. -V. 149-156; added.-V. 165, 166; altered--V. 171-196; mueh omitted, and much added; of the Thames.-V. 217-237; much altered. - V. $241-300$; much added of the chase. $-V .307$ -310 ; simile added.-V. $319-322$; altered for the better.V. 327 ; six party lines omitted.-V. 342 ; party lines omitted. - V. 357 ; others, of the same kind, omitted in the close. 
all with admirable judgment; and the whole read togetber is a very strong proof of what Mr. Waller says:

"Poets lose half the praise they should have got, Could it be known what they discreetly blot." $-P$.

It was our family priest (Banister) who taught me the figures, aceidence, and first part of grammar. If it had not been for that, I should never have got any language: for I never learued anything at the little schools I was at afterwards ; and never should have followed anything that I could not follow with pleasure.-I had learned very early to read, and delighted extremely in it; and taught myself to write, very early too, by eopying from printed books; with which I used to divert myself, as other children do with serawling out pictures.* $-P$.

The Iliad took me up six years; and during that time, and particularly the first part of it, I was often under great pain and apprehension. Though I conquered the thoughts of it in the day, they would frighten me in the night.-I sometimes, still, even dream of being engaged in that translation; and got about half way through it: and being embarrassed and under dread of never completing it. $-P$.

If I lad not undertaken that work, I should certainly have writ an epic; and I should have sat down to it with

* When Mr. Pope got into the way of teaching himself, and applied so elose to it in the Forest; some of his first exercises were imitations of the stories that pleased him most in Ovid, or any other poet that he was reading. I have one of these original exercises now by me, in his own hand. It is the story of Acis and Galatea, from Ovid; and was translated when he was but fourteen years old. The title-page to this, (from his manner of learning to write, is so like print, that it requires a good eye, and nice regard to distinguish it.-Spence. 
this advantage, that I had been nursed up in Ilomer and Virgil.-P.

The following Epigram was marle by Rowe, upon Phil. Frowl's uncle when he was writing a tragedy of Cimna:

Frowd for his precious soul cares not a pin-a;

For he can now do nothing else but Cin-na.

. I thought Rowe had been too grave, to write sueh things?"- - He !-why he would laugh all day long! he would do nothing else but laugh. $-P$.

"The nobleman-look."-Yes, I know what you mean very well: that look which a nobleman should have; rather than what they have generally now.-P.

The Duke of Buekingham (Sheffield) was a genteel man; and had a great deal the look you speak of.-Wyeherley was a very genteel man; and hal the nobleman-look as much as the Duke of Buckingham.-P. [He instanced it too in Lord Peterborough; Lord Bolingbroke; Lord Hinchinbroke; the Duke of Bolton, and two or three more.-Spence.]

Ir. Pope has still a good memory; and that both of the sensible and loeal kind.-When I consulted him about the Hades of the ancients; he referred immediately to Pindar's second Olympie ode, I'lutareh's Treatise de Iside et Osiride, the four places that relate to it in the Odyssey, (though this was so many years after he had done that translation,) Plato, Lueretius, and some others; and turned to the very passages in most of them, with a surprising readiness._—_ "Pray what is the Asphorlil of Homer?"-Why I believe, if one was to say the truth, 'twas nothing else but that poor yellow flower that grows about our orehards: and if so, the verse might thus be translated in English :- 
“" the stern Achilles

Stalked through a mead of daffodillies." $-P$.

Good part of the ballad on Lechmere and Guise was written by Mr. Pope.-The ballad on the rabbit-woman, by him and Mr. Pulteney: they wrote two or three more together. $-P$.

When Cowley grew sick of the court, he took a house first at Battersea, then at Barnes; and then at Chertsey : always farther and farther from town. In the latter part of his life, he showed a sort of aversion for women ; and would leave the room when they came in: 'twas probably from a disappointment in love. He was much in love with his Leonora; who is mentioned at the end of that good ballad of his, on his different mistresses. She was married to Dean Sprat's brother; and Cowley never was in love with anybody after. $-P$.

Addison usually studied all the morning: then met his party at Button's ; dined there, and stayed five or six hours ; and sometimes far into the night.-I was of the company for about a year, but found it too much for me: it hurt my lealth, and so I quitted it. $-P$.

Addison passed each day alike; and much in the manner that Dryden did.-Dryden employed his mornings in writing; dined, en famille; and then went to Wills's : only he came home earlier a'nights.- $P$.

The night after King Charles the first was beheaded, my Lord Southampton and a friend of his got leave to sit up by the body, in the banqueting-house at Whitehall. As they were sitting very melancholy there, about two o'cloek in the morning, they heard the tread of somebody coming very slowly up stairs. By-and-by the door opened, 


\section{SECTIOY VII. 17+2-43. 217}

and a man entered, very much muftled and his face quite hid in it.-He approached the body, considered it, very attentively, for some time: and then shook his head and sighed out the words, ' cruel necessity ?" - He then departed in the same slow and concealed manner as he hal come in.-Lord Sonthampton used to say, that he could not distinguish anything of his face; but that by his voice and gait, he took him to be Oliver Cromwell.-P? 


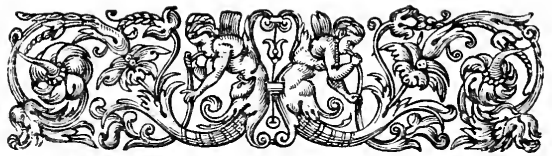

\section{SPENCE'S ANECDOTES.}

\section{SECTION VIII. $1743-44$.}

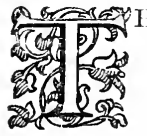

HE ilea that I have had for an Epie poem, of late, turns wholly on eivil and ecelesiastical government. The hero is a prince who establishes an empire. That prince is our Brutus from Troy; and the scene of the establishment, England. The plan of government, is much like our old original plan; supposed so much earlier: and the religion, introdued by him, is the belief of one God, and the doetrines of morality.-Brutus is supposed to have travelled into Egypt; and there to have learned the unity of the deity, and the other purer doctrines, afterwards kept up in the mysteries.-Though there is none of it writ as yet, what I look upon as more than half the work is alrealy done; for 'ris all exactly planned.-_-“ It would take you up ten years?" - Ob much less, I should think, as the matter is already quite digested and prepared.*-Pope.

* The plan of this Epic, fully detailed, may be found in Ruffhead's Life of Pope, p. 410. It is perhaps well for Pope's reputation that he did not find leisure to carry this project into execution. Dr. 
What was first designed for an Epistle on Edueation, as part of my essay-seheme, is now inserted in the fourth book of the Innciad; as the suljeet for two other epistles (those on eivil and ecelesiastical polity) will be treated more at laree in my Brutus. $-P$.

I never save anything: unless I meet with such a pressing casc, as is absolute demand upon me. Then I retrench fifty pounds or so from my own expenses. As, for instance, bad such a thing happened this year, I would not have built my two summer-houses. $-P$.

I would be buried in Twiekenham Chureh, if I should fail anywhere near it: in the place where my father and mother lie. And would have no other epitaph, but the words sibiqre oвirt, and the time, alded to theirs.** $P$.

In the list of papers, ordered to be burnt, were the pieees for carrying on the Memoirs of Seriblerus; and several copies of verses by Dean Parnell. I intereeded in vain for both. As to the latter, he sail that " they would not add anything to the Dean's character." $-P$.

The rule laid down in the begimning of the Essay on

Warton has well observed, that so didaetic a genius would probably have been dencient in the sublime and pathetie, which are the main nerves of the Epopea. That his poem would have more resembled the Henriude than the Ilial, and have shown more of the philusopher than the poet.-Editor.

* His remains were deposited in the same vault with those of his frarents, to whose memory he had ereeted a monument with the following inseription. D. o. M. ALExander POPE, viro iNsocuo, probro, p1o, QUi vixit ANNos LXxv. Ob. MDCCXvir. ET EDITH. CONJCGI INCCLPABiLI, QRi vixit aNNos xé1I. OB. MDCCXXXII. PARENTIBUS BENE MERENTIBUS FILICS FECIT ET sibi. obuit AN, 1744, „xtatis 56 . The last line was added after his death.-Editor. 
Man, of reasoning only from what we know, is eertainly a right one; and will go a great way toward destroying all the school metaphysies: and as the chureh writers have introdueed so mueh of those metaphysies into their systems, it will destroy a great deal of what is advaneed by them too. $-P$.

At present, we can only reason of the divine justice, from what we know of justice in man. When we are in other seenes, we may have truer and nobler ideas of it : but while we are in this life, we ean only speak from the volume that is laid open before us. $-P$.

The theological writers, from Clarke down to Jacob Behmen, have all (almost equally) Platonised and corrupted the truth. That is to be learned from the Bible, as it appears nakedly there; without the wresting of eommentators, or the additions of schoolmen. $-P$.

There is hardly any laying down partieular rules for writing our language: even Dean -Swift's, which seemed to be the best I ever heard, were, three in four of them. not thoroughly well grounded.*-In most doubts, whether a word is Euglish or not, or whether such a partieular use of it is proper, one has nothing but authority for it. Is it in Sir William Temple, or Locke, or Tillotson?-If it be, you may conelude that it is right, or at least won't be looked upon as wrong. $-P$.

* One of the greatest difficulties in our language, lies in the use of the relatives; and the making it always evident to what anteredents they refer. $-D r$. Suift to Mr. Hooke.-The following is an instance of what Swift used to call the Parson's style. "That were not of the growth, or at least, made free of Rome."-It should be-" That were not of the growth of Rome, or at least, made free of it."-Hooke. Addition from MS. B. 
"The great seeret how to write well, is to know thoroughly what one writes about, and not to be affieterl." - $[\mathrm{Or}$, as he expressed the same thing afterwarls in other words, " to write naturally, and from one's own knowledge." $-P$.

There was a Lord Russell who, by living too luxuriously, had quite spoiled his constitution. He did not love sport, but used to go ont with his logs every day, only to hunt for an appetite. If he felt anything of that, he wonld ery out, 'Oh, I have found it "' turn short round and ride home again, though they were in the midst of the finest chace.It was this Lord, who, when he met a beggar, and was entreated by him to give him something because he was almost famished with hunger, called him ". a happy $\log$ ?" and envied him too much to relieve him.- $P$.

On Lord Hyde's return from his travels, his brotherin-law, the Lord Essex, told him, with a great deal of pleasure, that he had got a pension for him. It was a very handsome one. and quite equal to his rank.-All Lord Iyde's answer" was: " ILw could yon tell, my lorl, that I was to be sold? or at least, how could you know my price so exactly?" $-P$. [It was on this account that MIr. Pope compliments him with that passage-

_- disdain, what Cornbury disdains."-Spence.]

Mr. Pope altered some verses in the Duke of Buekingham's Essay on Poetry; as he likewise did many in Wycherley's poems. $-P$.

Lydia, in Lady Mary Wortley Montague's Poems, is almost wholly Gay's ; and is published as such in his works. There are only five or six lines new set in it by that lady. 
It was that which gave the hint; and she wrote the other five eclogues. $-P$.

L'Estrange's excellent fable-style, is abominable in his translation of Josephus : and it is the same in his imitator, Collier, as to his lighter pieces, and his translation of Marcus Antoninus. $-P$.

I should not choose to employ some that could do it, to translate some of my poems into Latin; because, if they lid it as they ought, it would make them good for nothing else. $-P$.

- Yes, I really think Betterton the best actor I ever saw : but I ought to tell you at the same time, that in Betterton's days the older sort of people talked of IIarte's being his superior, just as we do of Betterton's being superior to those now.- $P$.

"I shall be very glad to see Dr. Hales; and always love to see him, he is so wortby and good a man."-Yes, he is a very good man; only I'm sorry he has his hands so much imbrued in blood._-" What, he euts up rats?"Ay, and dogs too !- [With what emphasis and concern he spoke it.] -." Indeed, he commits most of these barbarities, with the thought of being of use to man: but how do we know, that we have a right to kill creatures that we are so little above as $\log \mathrm{s}$, for our curiosity, or even for some use to us?"- $P$.

"I used to carry it too far; I thought they had reason as well as we."-So they have to be sure.-All our disputes about that, are only disputes about words.-Man has reason enough only to know what is neeessary for him to know; and dogs have just that too._- But then they must 
have souts too: an unperishable in their nature as ours." - And what harm would that be to us :- - I'.

lord P'eterborough coubl dietate letters to nine amanuenses together : as I was assured ly a gentlemam who saw him do it when ambassider at 'l'urin.-1He walked round the room, and told each in his turn what he was to write. -One perhaps was a letter to the emperor, another to an old friend, a third to a mistress, a fouth to a statesman, and so on: yet he earried so many and so different connexions in his head, all at the same time. $-P$.

Lord Peterborough was not near so great a genitus as Lord Bolingbroke.-They were quite unlike. Lord Peterborough, for instance, in the ease just mentioned, would saly pretty and lively things in his letter's: but they would be rather too gay, and wandering: whereas, was Lord Bolingbroke to write to the emperor, or to the statesman, he would fix on that point which was the most material; and would set it in the strongest and finest light, and manage it so as to make it the most serviceable to his purpose.-p.

There is one thing in Lorl Bolingbroke, which seens peculiar to himself. Ite has so great a memory as well as judgment, that if he is alone, and without books, he can set down by himself, and refer to the books, or such a partieular subject in them, in his own mind; and write as fully on it, as another man would with all his books about him. I Le sits like an Intelligenee, and reeolleets all the question within himself. $-P$.

The old Duchess of Marlborough has given away in charities, and in presents to granddanghters and other 
relatives, near three hundred thousand pounds in her lifetime. $-P$.

I had twelve lundred pounds for my translation of the Iliad, and six hundred for the Odyssey; and all the books for my subseribers, and presents into the bargain.*- $P$.

I must make a perfect edition of my works; and then shall have nothing to do but to die.- $P$.

It was that stanza in Spenser, that I at first designed for my motto to the Dunciad. $-P$.

"As gentle shepherd in sweet even-tide When ruddy Phœbus 'gins to walk in west, High on a hill, (his flocks to vewen wide,) Marks which do bite their hasty supper best :

A cloud of cumbrous gnats do him molest, All striving to enfix their feeble stings;

That from their noyance, he nowhere can rest :

But with his clownish hands their tender wings He brusheth oft ; and oft doth mar their murmurings."

[I remember this was written down in the first MS. copy of the Dunciad. - It hits the little impertinent poets, that were brushed away by that poem, very well; but fails in other points, (as " with his elownish hands," in particular, ) and therefore, I suppose, was omitted by him.-Spence.]

After reading a canto of Spenser two or three days ago

* His contract with Lintot was that he should receive two hundred pounds for each volume of the Iliad besides all the copies for his subscribers, and for presents.-The subscribers were five hundred and seventy-five, many subseribed for more than one copy, so that he must have received upwards of six thousand pounds. He was at first apprehensive that the contract might ruin Lintot, and endeavoured to dissuarie him from thinking any more of it. The event, however, proved quite the reverse; the snccess of the work was so unparalleled as at once to enrich the bookseller, and prove a productive estate to his family.-Editor. 
to an old lady, between seventy and eighty years of age, she said that I had been showing her a gallery of pietures. -I don't know how it is, but she said very right: there is something in Spenser that pleases one as strongly in one's old age, as it did in one's youth. I read the Faerie Queene, when I was about twelve, with infinite delight; and I think it gave me as mueh, when I real it over about a year or two ago. $-P$.

When I had a fever, one winter in town, that confined me to ny room for five or six days, Lord Bolingbroke, who eame to see me, happened to take up a Horaee that lay on the table; and in turning it over, dipped on the first satire of the second book, whieh begins Sunt quibus in sutirâ, \&c. He observed, how well that would hit my case, if I were to imitate it in English. After he was gone, I read it over; translated it in a moming or two, and sent it to the press in a week or fortnight after. And this was the oeeasion of $\mathrm{my}$ imitating some other of the satires and epistles afterwards. $P$. [To how casual a beginning are we obliged for some of the most delightful things in our language: When I was saying to him that he had already imitated a third part of Horaee's Satires and Epistles ; and how much it was to be wished that he would go on with them; he could not believe that he had gone near so far: but, upon computing it, it appeared to be above a third.-He seemed on this not disinelined to earry it further; but his last illness was then growing upon him, and robbed us of him and all hopes of that kind in a few months after.-Spence.]

I have imitated more than are printed ; and particularly the fourth satire of the seeond book.-Before this hint from Lord Bolingbroke, I had translated the first satire of the 
first book. But that was done several years ago, and in quite a different manner. It was much eloser, and more like a downright translation. $-P$.

Cromwell was inelined to spare the king, till he found there was no trust to be put in him. 'Tis said, at least there was a private correspondence earriel on between them, for some time. Cromwell was to restore the king to his full regal power, and was himself to be made Lord Lientenant of Ireland, with some other advantageous articles. The queen heard of this, and wrote to the king to desire him " not to yield too mueh to the traitor." The king in his answer said, " she need not have any eoncern in her mind on that head: for whatever agreement they might enter into, he should not look upon himself as obliged to keep any promises made so much on eompulsion, whenever he had power enough to break through them." Cromwell intereepted this answer, and from that moment, acted always uniformly to take away the king's life.* $-P$.

* This is somewhat difierently related by the younger Richardson, in his rambling way. "Lord Bolingbroke told us (June 12, 1742), that Lord Oxford had often told him, that he had seen, and had in his hand, an original letter King Charles the First wrote to the Queen, in answer to one of hers that had been intercepted, and then forwarded to him; wherein she reproached him for ' having made those villains too great concessions,' (viz. that Cromwell should be Lord Lieutenant of Ireland for life, withont account; that the kingdom should be in the hands of the party, with an army there kept, which should know no head but the lieutenant; that Cromwell should have the garter, \&c.) That in this letter of the king's it was said, ' that she should leave him to manage, who was better informed of all circumstances than she could be; but that she might be entirely easy as to whatever concessions he should make them; for that he should know in dne time bow to deal with the rogues, who instead of a silken garter, 
[Lord Bolingloroke said he was not ill where he was: that he harl male several friendships, and did not dislike the country:-but that if he might be fully restored he should be obliged.-This was absolutely promised.-1Ie was several times with the king, and told him of his promise; the king said he should be glad to perform it, but that his ministers assured him so many of the lords were so much prejudiced against Lord Bolingbroke, that the bill would never pass the house.-Lord Bolingbroke told the king that it was all false: that it would pass the house if Sir Robert Walpole had a mind to make it do so, and that if the king toll him he should, that he must.-" Sir Robert is but two or three rooms off (said Lord B.), if you will order him to be called in, I will tell him all that I have said to your majesty, and convince him how it may be done.""No, no, (replied the king, don't eall him in." $-P$.

The king was heard to say in the drawing-room, upon the falling of the South Sea stock: "We had very good luck: for we sold out last week." $-P$.

Kings now (exeept the King of Sardinia) are the worst things upon earth. They are turned mere tradesmen; cant,onantes bellem, non belligerantes. $-P$.

Cotta and his heir were supposed by some to have been the late and present Duke of Neweastle. "Foe to the

should be fitted with an hempen cord.'-So the letter ended; which answer, as they waited for, so they intercepted aceordingly, and it determined the ling's fate.-This letter Lord Oxford said he had offered five hundred pounds for.-Lord Bolingbroke, Lord Marelumont, and Mr. Pope, all believed that the story I had heard or read to this purpose (and which occasioned Lord Bolingbroke's telling the above) had its origin no higher than this story of Lord Oxford."-Editor. 
Dryads of his father's groves." Mr. Pope did not confirm it outright, when I mentioned it to him, but spoke of their eharacters in a manner that seemed not at all to disown it. -Spence.*]

Lord Bolingbroke quitted the Pretender, beeause he found him ineapable of making a good prince. He himself, if in power, would have made the best of ministers.-These things will be proved one of these days. The proofs are ready, and the world will see them. $\uparrow-P$.

One may form some idea of the consisteney of foreknowledge and free-will, from the instanee of a tutor and a child. -If you know the temper and custom of a man thoroughly, and the eireumstanees of the thing offered to him, you know often how he will choose: and his ehoice is not at all the less free for your foreseeing it.-A man always chooses what appears best to him: and if you certainly foresaw what would appear best to him, in any one particular case, you would eertainly foresee what he would choose.-P.

I have thought it ovcr, and am quite willing to leave this world. It is too bad to desire to stay on in it: and my spirit will go into the hands of him, who I know will not use it worse than it has deserved.- $P$.

I would leave my things in mereiful hands.-I am in no concern, whether people should say this is writ well or ill, but that this was writ with a good design.-- He has written in the cause of virtue, and done something to mend

* The four preceding articles are taken from Mr. Spence's Papers.-Editor.

+ This is most probably a hint at the edition of the "Patriot King" he had caused to be printed, without Bolingbroke's knowledge.-Edilor. 
people's morals:" this is the only commendation I long for. $-P$.

Hughes was a good humble-spirited man, a great admirer of Mr. Aldison, and but a poor writer, exeept his play, that is very well. $* P$.

- Hughes died in February 1719-20, on the first night his Siege of Bamascus was aeterl, and wrote the Prologne and Epilogue for it in bed, and the Dedication to Lord Chancellor Cowper, only ten days before his death. He was about forty-five years old. It was the sight of that play in manuscript that recommended him entirely to Lord Cowper, who made him Secretary to the Commissions of the Peace, a month after he read it: and when Lord Parker sueceeded him, though Lord C. was too angry with him to desire him to continue any one else, he did desire him to eontinue Mr. Hughes. Lord Parker did so, and told him that Lord C. had recommended him to him, but that he had a previous recommen. dation; which was his own merit. He was never in any eircumstances till his secretaryship; which was but a few years before his death.-Mr. Strahan only received one hundred and twenty. five pounds for tickets for his play, and had not the pleasure of delivering that to him, but to his mother. He left above five hundred pounds to his family, who mueh wanted it.-Addition from Mr. Spence's Papers.

In answer to an obserration of Swift, that Hughes " is among the mediocrists in prose and verse :" Pope replies, " as to Hughes, what he wanted in genius he made up as an honest man; but he was of the elass you think him."-It has been sail that Pope, in this ease acted with duplicity, because he praises the Siege of Damascus in a letter to Hughes, written the very day be diel; and in a subsequent letter to his brother, praises both the work and the author.-Dr. Johnson gives his sanetion to this character of Hughes and has also been eensured for doing so.-We have here a proof that Pope's opinion of Hughes's talents, was not a mere echo of that of Swift, and we see that he exeepts his play from the censure. But this is not the only instance of Pope's insincerity in his epistolary commerce with mankind, all his eorrespondents are made easy by flattery, laid on without conscience or remorse.Editor. 
There neverwas anything so wicked as the Holy Wars. $-P$. In the Island of St. Christopher, there are a number of creatures like lizards; some green, some red, and others yellow: which change their natural colour to some other, almost instantly, on being pricked with a needle. They frequent the fig-trees there, much; one of which makes a wood of itself : the branches growing down to the ground, and taking root there, and then growing on, and doing the same again.-I have seen, I believe, five hundred of these creatures at once sitting under one of these natural fig-tree arbours.-Mr. $B$.

I have never been at the city of Mexico myself; but a particular friend, who has been there, and whom I could absolutely trust to, has assured me, " that he was never struck so much with anything, as with the magnificence now used there:" and yet he had been in several of the most splendid courts of Europe, before he went thither. He said, in particular, that there were above seven hundred equipages, with the harness of solid silver.-And when they go out on one of the great eauseways, which is the walk in fashion at present, every lady has a black slave on each side of her, with an umbrella to shade her from the sun; and a third to hold her train.- $I r . B$.

The Epistle on "The Use of Riches," was as much laboured as any one of my works. $-P$.

A great lawyer, who had a very bad son, in his last will left him a legacy to such a value, and this verse of $\mathrm{Mr}$. Pope's to think often of,

"An honest man's the noblest work of God."

- Mr. Murray (aftemuards Lord Mansfield.)

I had once a design of giving a taste of all the most 
celebrated Greek poets, by translating one of their best short pieces at least from each of them. A hymn of 1 lomer, another of Callimachus, an ode or two from Pindar, and so on: and I should have done so had not I engaged in the translation of the Iliad. What led me into that, which was a work so mueh more laborions and less suited to my inelination, was purely the want of money. I had then none; not eren to biy books. $-P$.

Lord Oxford was always dissuading me from engaging in that work. He used to eompliment me by saying, that "so good a writer ought not to be a translator." IIe talked always very kindly to me: and used often to express his. concern for my continuing incapable of a place: which I could not make myself capable of, without giving a great deal of pain to my parents; such pain, indeed, as I would not have given to either of them, for all the places he could have bestowed upon me.- $P$.

That lord never said anything of a pension to me: and it was to the whig ministry, that I was wholly obliged for any thoughts of that kind.- $-P$.

In the begimning of George the First's reign, Lord Ifallifax sent for me of his own aceord. He said he had often been eoneerned that I had never been rewarded as I deserved; that he was very glad it was now in his power to be of serrice to me, that a pension should be settled on me, if I eared to aceept it; and that nothing should be demanded of me for it.-I thanked his lordship, in general terms, and seemed to want time to consider of it.-I heard nothing further for some time; and about three months after I wrote to Lord Hallifax, to thank him for his most obliging offer; saying, that I had considered the matter 
over fully, and that all the difference I could find in having or not having a pension, was, that if I had one, I might live more at large in town, and that if I had not, I might live happily enough in the country.-There was something said too, of the love of being quite free, and without anything that might even look like a bias laid on me.-So the thing dropped, and I had my liberty without a eoach.*-P.

Craggs, afterwards, went farther than this.-He told me, as a real friend, that a pension of three hundred pounds a year was at my service; and that, as he had the management of the sccret-serviee money in his hands, he could pay me such a pension yearly without any one's knowing that I had it.-I declined even this: but thanked Mr. Craggs for the heartiness and sineerity of his friendship, told him that I did not much like a pension any way; but that, since he had so much goodness toward me, if I should want money, I would eome to him for a hundred pounds, or even for five hundred, if my wants ran so high.-P. [I do not

- These anecdotes were in the hands of Dr. Johnson, during the time he was writing his Lives of the Poets, yet this has escaped him.-After quoting the anecdote of Lord Hallifax, which stands at the head of the fourth section, he observes. "It is seldom that the great or the wise suspect they are despised or cheated. Hallifax, thinking this a lucky opportunity of securing immortality, made some advances of favour and some overtures of advantage to Pope, which he seems to have received with sullen coldness. All our knouledge of this transaction is derived from a single letter (of Dec. 1, 1714.)"-In which Pope says in substance what is stated above.-" They probably were suspicious of each other (says Dr. Johnson). Pope would not dedicate till he saw at what rate his praise was valued; he would be troublesome out of gratitude, not ex. pectation. Hallifax thought limself entitled to confidence, and would give nothing unless he knew what be should receive. Their commerce had its beginning in hope of praise on one side, and of 
find that he ever did go to Mr. Craggs for anything ufter all, and have been assured by some of his friends, who knew his private affiurs the most intimately, that they think he never did.-Sipence.]

Craggs was so friendly as to press this to me scveral times, and always used to insist on the convenience that a coach would be of to me, to incline me to accept of his kind offer. 'Tis true, it would have been very eonvenient: but then I considered, that sueh an addition to my ineome was very uneertain, and that if I had reeived it, and kept a coach for some time, it would have made it more inconvenient for me to live without one, whenever that should fail. $-P$.

Mr. Pope never flattered anybody for money, in the whole course of his writing. Alderman Barber had a great inelination to have a stroke in his commendation inserted in some part of Mr. Pope's writings. He did not want

money on the other, and ended, beeause Pope was less eager of money, than Hallifax of praise. It is not likely that Hallifax had any personal benevolence to Pope; it is evident that Pope looked on Hallifax with seorn or hatred."-But in the Ireface to the Iliad, Pope did design to flatter him, and says, "The Earl of Hallifax was one of the first to favour me, of whom it is hard to say, whether the advancement of the polite arts is more owing to his generosity or his example." And in a note on the Epilugue to the Satires calls him, " $A$ peer no less distinguished by his love of letters, than his abilities in parliament." And yet, with his nsual duplieity, he satirized him under the charaeter of Bufo in the Prologue to the Satires.-Hallifax also overluaded Swift with eompliments and promises; but Swift does not appear to have been his dupe. In a small book of French verses, found in his library at his decease, he had written these words, "Given me by Lord Hallifax, May $3 d, 1709$; I begged it of him, and desired him to remember it was the only ruvour I ever received from him or his party."-Editor. 
money, and he wanted fame. He would probably have given four or five thousand pounds, to have been gratified in this desire: and gave Mr. Pope to understand as mueh, but Mr. Pope would never comply with such a baseness. And when the Alderman died, he left him a legaey only of a hundred pounds; which might have been some thousands, if he had obliged him only with a couplet.-Mr. Warburton, who had it from $\mathrm{Mr}$. Pope, and I have been assured of it by others who knew both Mir. Pope and the Alderman very well.

When Mr. Pope's nephew, who had been used to the sea, refused a very handsome settlement that was offered him in the West Indies, and said, that fifty pounds a year was all he wanted, and that it would make him happy-Mr. Pope (instead of using arguments to persuade him not to refuse so advantageous a proposal) immediately offered to settle the yearly sum upon him, which he said would make him happy.—Mr. Warburton.

A hidden doctrine, as well as a vulgar one, was so neeessary, that it was used, not only in China and Egypt, but in all the heathen nations of old.- The hidden doctrines of the union of the Deity, and of the immortality of the soul, were originally in all the Mysteries, even in those of Cupid and Bacehus.- $W$.

The Mysteries, at first, were the retreats of sense and virtue : till time corrupted them, in those of most of the $\operatorname{gods}$, (for there were mysteries belonging to each;) but more particularly, as was naturally to be expected, in those of Bacehus and Cupid.-The general progress of idolatry, in most nations, has been the same. People began with worshipping the sun, moon, and stars; - then, after entering 
into society, each their public benefactors, as such; and, lastly, the same as real divinities, to hide the nonsense of worshipping made gods-Momes, or the complaining against P'rovidence, was originally supposed to be the son of Low and Chas, or Iynorance and Disoreler: but afterwards, when the Greeks grew wicked, it was turned into a character of Wit.-W.

In talking orer the design for a dietionary, that might be authoritative for our Linglish writers; Mr. Pope rejected Sir Walter Raleigh twice, as too affected.-The list for prose authors (from whose works such a dietionary should be collected) was talked over sereral times, and quite settlet. There were eighteen* of them named hy Mr. Pope, but fourt of that number were only named as authorities for familiar dialogues and writings of that kind._-" Should I not write down Hooke and Middleton?"-Ay, and I think there's searee any more of the living that you need name. $-P$.

The list of writers, that might serve as anthorities for poetical language, was begm upon twiee, but left very imperfeet. There were but nine + mentioned, and two of thoses only for the burlesque style.- $-P$.

The elief difticulty in a work of this kind, would lie in giving definitions of the names of mixed modes. - As to the

* Lord Bacon, Hooker, IIobbes, Lord Clarendon, Barrow, Tillotson, Dryden, Sir William Temple, Locke, Sprat, Atterbury, Addison, Swift, Lord Bolingbroke.

+ Ben Jonson, L'Estrange, Congreve, and Vanbrugh.

$\ddagger$ Spenser, Shakespeare, Fletcher, Waller, Butler, Milton, Dryden, Pryor, Swift.

$\S$ Butler and Swift.-Fleteher too was only mentioned as an authority for familiar dialogue, and the slighter kinds of writing. 
names of things, they are very well ascertained.-It would be difficult too, to settle what should be done as to the etymologies of words. If given to all, they would be often very trifling, and very troublesome; and if given to none, we should miss some very sensible originals of words.-Mr. Warburton.

The Abbé Pluche's founding his whole scheme on the original signification of names, would not be of any great weight, even though he should not have falsified their significations.--The original languages were very narrow in words; so that in them the same word usually stands for forty different things. Hence it is that one ean prove everything to have been derived from terms of agriculture; another, from terms of navigation; a third, from terms of war; and a fourth, from the names of the patriarchs. Pluehe, 'tis true, has a peeuliar simplicity in his scheme, but it should be eonsidered, that simplicity may serve falsehood as well as truth: thongh it is always beantiful, 'tis sometimes fallacious. $-W$.

There is scarce any work of mine in which the versification was more laboured than in my pastorals. $-P$. [The Messiah was his favourite above all the others.]

Though Virgil, in his pastorals, has sometimes six or eight lines together that are epic: I have been so scrupulous as scarce ever to admit above two together, even in the Messiah.- $P$.

There is a sweetness, that is the distinguishing character of pastoral versification. The fourth and fifth syllables, and the last but two, are ehiefly to be minded: and one must tune each line over in one's head, to try whether they go right or not. $-P$. 
"Dit you ever learn anything of music?"-Nerer: but I had a very good ear; and have often jutged right of the best compositions in musie by the foree of that."-l'.

The Duke of Marlborough was long in correspondence with the Pretender. IIe sent him several sums, and partieularly five thousand pounds at the time of his experdition against Scothand, by Robin Arbuthnot, then a banker at Boulogne. Lord Sunderlind had strong dealings too, and even Lord Godolphin.-P.

Lord Sunderland used to betray all the whig-sehemes to Harley; and the Duchess of Narlborough has got a letter of his, from some of Lord Oxford's people, which is a very full proof of it.- She has read it to me.-P.

The Duehess of Marlborough has a large and very material collection of papers; but I fear she burns sneh as will not make for those she loved:- - that was not the ease with Lord Sunderland.- $P$.

Lord Oxford was not latterly in the Pretender's interest. $\dagger$ He may have put on the appearance of being so, to some

- Pope does not appear to have been correct in this assertion. He was quite insensible to the merits of Handel, and seriously in. quired of Dr. Arbuthnot, whether the applause bestowed on that great eomposer was really deserved.-Gay coull play on the flute, and was therefore enabled to adapt so happily some of the airs in the Beggar's Opera.-Milton, Gray, and Mason were exquisite judges of this enchanting science, and two or three of our living poets of eminence, remarkable as great masters of versification, are also excellent musicians.-Editor.

† The following singular variation exists in the first memorandum of this conversation. "Lord Oxford was latterly in the Pretender's interest, but not Lord B.—Bromley, \&c." The blanks and initials of names in this and three preceding articles are filled up from those original notes; and the three following articles are derived from them.-Editor. 
great men; bnt he betrayed them, by making his peace with the present family without their knowledge. $-P$.

[Several great whigs were for bringing in the Pretender about the year 1714. The Duke of Marlborough was to advance thirty thousand pounds for that expedition; and my unele, Robin Arbuthnot, actually returned ten thousand pounds of it for him.-Niss Arbuthnot.

Lord Peterborough was well inclined, and 'twas a great mistake then, not to make him general of that expedition. He was the fittest man in the world for it, as he loved difficulties, and was famons for doing great things with little means._-" That spirit, I hope, is pretty well worn out now?"-I don't know.-Everyborly is for their own interest; and if there was any likelihood of sueceeding, it is possible the great men would be for it now : perhaps more than they were then.-Pope.

'Tis no matter' what the world says of us.- If a man is sensible that he has always acted for the good of his country, he may always lay down his head with pleasure on his pillow: and this is the great satisfaction that I enjoy, and have always enjoyed, amidst all that has been said against me.-Lord Botingbroke. May 1744.*]

I had once thonght of completing my ethie work in four books.- The first, you know, is on the Nature of Man.The second, would have been on Knowledge and its limits : -here would have come in an Essay on Education; part of which I have inserted in the Dunciad.- The third, was to have treated of Govermment; both eeclesiastical and eivil -and this was what chiefly stopped my going on. I could not have said what $I$ would have said, without provoking

* The three last articles are added from Mr. Spence's Papers. 
every ehurdh on the fatee of the earth: and I diul not eare for living always in boiling water.-This part would come into my Brotus, which is all planned already; and even some of the most material speecles written in prose.-The fourth, would have been on Morality ; in eight or nine of the most coneerning branches of it : four of which would have been the two extremes to each of the Cardinal Virtues. $-P$.

Faets in Ineient IIistory, are not very instruetive now; the principles of acting vary so often and so greatly.-The actions of a great man were quite different, even in Seipio's and Julins ('iesar's times.-P.

We have had a new set of motives and prineiples all over Europe, sinee the Pyrenean treaty; so that the only part even of our own history, neessary to he thoroughly studied now, does not go a great way lack.-This is the opinion of Lord Bolingbroke, who knows more of Europe, than perhaps all Europe put together at present. $-P$.

"I really think there is something in that great man (Lord Bolingbroke) which looks as if he was placed here by mistake."-There is so ; and when the comet appeared to us a month or two ago, I had sometimes an imagination that it might possibly be come to our world to earry him home; as a coach eomes to one's door', for other visitors. $-P$.

I used formerly to like Mr. Addison's Letter from Italy extremely, and still like it the most of all his poems: even more than his Campaign. $-P$.

I have followed the significance of the numbers, and the adapting them to the sense, mueh more even than Dryden ; and much oftener than any one minds it. Particularly in the translations of Homer, where 'twas most 
necessary to do so: and in the Dunciad, often, and indecd in all my poems. $-P$.

The great rule of verse is to be musical; this other is only a secondary consideration, and should not jar too much with the former.-I remember two lines I wrote, when I was a boy, that were very faulty this way. 'Twas on something that I was to describe as passing away as quick as thought:-

"So swift,-this moment here, the next 'tis gone,

So imperceptible the motion."-Pope.

"I did not use to like that verse in the Iliad:-

"He lies a lifeless load along the land;"

perhaps from its having a liquid in almost every word in it."-Ay, but that does not make it run on like a riververse: it only weakens it. 'Tis as the thing described; nerveless and yet stiff. $-P$.

Lord Bolingbroke, in everything, has been acting for the good of the public, for these twenty-five years; and without any view to his own interest.-Where he could get nothing by it, he has laid out much more money than those who were principally concerned, and could better afford it. $*-P$.

On somebody's coming to see him in his illness who said, "they heard he was going to put his faith in a new physician," he said: "No, I have not laid aside my old

* In the single point of intelligence in the affair of Dunkirk, and about that time, he was at the expense of four thousand pounds : When the other principal men that I could name, who could better afford it, did not expend above five hundred pounds. $-P$. He had been speaking of Sir William Windham and Pulteney.-Spence, from Pupers. 
physician and given myself up to a new one: any more than I have renouneed the errors of our church, and taken up with those of yours." $-P$.

When General Oglethorpe was conversing with a sensible old native of Georgia abont prayer; the latter said, that " they never asked anything of God, lut left it to him to do what he thought best for them : that the asking for any partieular blessing, looked to him like direeting God; and if so, must be a very wicked thing. 'That, for his part, he thought everything that happened in the world was as it should be: that ciod, of himself, would do for every one, what was consistent with the good of the whole; and that our duty to him, was to be eontent with whatever happened in general, and thankful for all the good that happened to us in particular."-Mr. Cheselden.

"Here an I, like Socrates, distributing my morality among my friends, just as I am dying." $-P$. [This was said on his semling about some of his Ethic Epistles, as presents, about three weeks before we lost him.-I repliel, " I really had that thought several times, when I was last at Twickenham with you; and was apt, now and then, to look upon myself like I'hædo."- That might be (said he); but you must not expect me now to say anything like Socrates._Spence.]

One of the things that I have always most wondered at, is that there should be any sueh thing as human vanity.If I had any, I had enough to mortify it, a few days ago; for I lost my mind for a whole day.-P. [This was said on the 10th of May; and the day he spoke of was the Sunday before, May the 6th. A day or two after he complained of that odd phenomenon (as he called it) of seeing 
everything in the room as through a eurtain.-On the 14 th he eomplained of seeing false colours on objeets. - \$pence.]

The 15th, on Mr. Lyttleton's coming in to see him, he said; "Here am I, dying of a hundred good symptoms!" [This was just after Dr. T. had been telling him, that he was glad to find that he breathed so much easier; that his pulse was very good; and several other eneouraging things.] -Spence.]

The thing that I suffer most from, is, that I fincl I camnot think. - $P$.

He said to me, "What's that?" pointing into the air, with a very steady regard; and then looked down on me, and said, with a smile of great pleasure and with the greatest softness, "Twas a vision."-Spence, (from Pupers.)

I had got the Regent's edition of the Longus's Daphnis and Chloe in my hand to read while he was dozing. " They are very innocent loves, like those of Adam and Eve in Milton (said he): I wonder low a man of so infected a mind as the Regent, eould have any taste for such a book." - $P$.

The greatest hero is nothing under a eertain state of the nerves.- His mind is like a fine ring of bells, jangled and out of tume.-Lorel Bolingbroke. [He himself has been in the vapours this last month, though he always used to laugh at it before: and that made him awake to this refleetion.*Hooke.]

There is so mueh trouble in eoming into the world, and so mueh more, as well as meanness, in going out of it; that 'tis hardly worth while to be here at all:-Lord $B$. [His Lordship's melancholy attitude on the morning of the 21st

* From Papers. 
was remarkable, leaning against $\mathrm{Mr}$. Pope's ehair; and erying over him for a considerable time, with more concen than ean be expressed.-Spence.]

[On the 27tl, speaking of his having so little to leave, he quoted two of his own verses very properly, on his whole life having been divided between earelessness and care.Hooke.] It was on this same day that he requested to be brought to the table where we were sitting at dinner; his appearance was such, that we all thought him dying. Mrs. Anne Arbuthnot involuntarily exclaimed; " Lord, have merey upon us! this is quite an Egyptian feast."-Spence, (firom Papers.)

"O great God! what is man?" said Lord B. looking on Mr. Pope and repeating it several times, interrupted with sobs.

Upon Mr. Cheselden saying, "There is no hope for him here ; our only hope for him must be-." Lord Bolingbroke said,-_" Pshaw !- we cau only reason from what is. we ean reason on actualities, but not on possibilities."

When I was telling his Lordship, that Mr. Pope, on crery eatehing and recovery of his mind, was always saying something kindly either of his present or his absent friends : and that this was so surprising, that it seemed to me as if his humanity had outlasted his understanding.-Lord B. said;-" It has so!"- -and then added, "I never in my life knew a man that had so tender a heart for his particular friends, or a more general friendship for mankind!"- " I have known him these thirty years : and value myself more for that man's love, than___." [Sinking his head, and losing his voice in tears.-Spence.] 
A short time before his death, Mr. Pope said, "I am so certain of the soul's being immortal, that I seem to feel it within me as it were by intuition."

When Mr. Hooke asked him, whether he would not die as his father and mother had done; and whether he should not send for a priest?-He said, "I do not suppose that is essential, but it will look right: and I heartily thank you for putting me in mind of it." *

In the morning, after the priest had given him the last saeraments ; he said, "There is nothing that is meritorious but virtue and friendship; and indeed friendship itself is only a part of virtue."

[When Mr. Hooke whispered this to Lord Bolingbroke, at table, he said alond; "Why, to be sure, that is the whole duty of man."-From Papers.]

Mr. Pope died the 30th of May (1744) in the evening; but they did not know the exact time: for his departure was so easy, that it was impereeptible even to the standers by.-MAY OUR END Be LIKE HIS :

- Iooke told Warburton ' that the priest whom he had provided to do the last office to the dying man, came out from him, penetrated to the last degree with the state of mind in which he found his penitent, resigned and wrapt up in the love of God and man.' -The priest had scarce departed(says Warton) when Bolingbroke, coming over from Battersea, flew into a great fit of passion and indignation, on the occasion of his being called in.-Editor. 


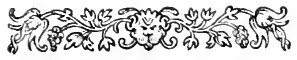

\section{SUPPLEMENTAL ANECDOTES, FROM}

\section{MR. SPENCE'S PAPERS.}

จ 



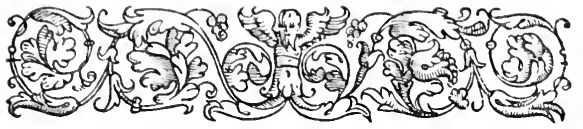

\section{SUPPLEMEN'TAL ANECDO'TES,}

FROM MR. SPENCE'S PAPERS.

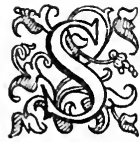

IR Isaac Newton, though he scarce ever spoke ill of any man, could hardly avoid showing his contempt for your virtuoso collectors and antiquarians. - Speaking of Lord Pembroke once, he said, " let him have but a stone doll and he is satisfied. I ean't imagine the utility of such studies: all their pursuits are below nature."-Fr. Chute.

I have heard Sir lichard Stecle say, that though he had a greater share in the Tatlers, than in the Spectators; he thought the news article, in the first of these, was what contributed much to their suceess.-IIe confessed that he was much hurt, that Addison should direct his papers in the Spectator. to be printed off again in his works. It looked as if he was too much eoncerned for his own fame, to think of the injury he should do the pecuniary interests of an indigent friend: particularly as in the Spectator itself, they were sufficiently asecrtained to be his by the mark cLIO.-He confirmed, in some degree, the character Pope gives of Addison: from what Sir Richard dropt, in various 
conversations, it seems to have been but too true.-Fr. Chute.

The Duchess of Portsmouth said to the King (William), " Le Prétendant est en Ecosse."-To which he replied: " Eh bien, il ne trouvera pas le Roi Jacques ici."-Another lady, that stood by, wishing he was hanged.-" Pourquoi? (said the king,) vous a-t-il fait du mal? pour moi, je le plains."-Fr. Chute.

Lord Cowper once declared to me, that he owed all the reasoning he was master of, to reading Chillingworth.Fr. Chute.

Fenton has another play on the stocks.-He was angry before Broome. They two had resolved on translating the Odyssey; Mr. Pope hearing of it, immediately said that he would make a third. At last he came to be principal in the work. Fenton had two hundred and forty pounds of him, and Broome six hundred.-Broome asked five, and upon Mr. Pope saying that was too little, and Broome naming seven; "Well then, (says Pope,) let's split the difference, there's six hundred for you." Broome and Fenton intend a joint work (something serious), and to advertise at the end of it, or to specify in the preface, exactly what share they lad in the translation. They had neither of them any hand in the little pamphlets, \&c. of the last year or two: but Mr. Blount used to send Broome all the little things as they came out.-Mr. Blount of Trwickenham, and of Clare Hall, Cambridge.

Mr. Pope is a whig, and would be a Protestant, if his mother were dead. $-M r$. Blount.

A serene melancholy, the most noble and most agreeable situation of the nind.-Revenge is only continued anger. 
- Thomson. [He laughed very heartily when we read the passage relating to Caroline: and that other of the glory of our nation.-His fine love piece before, not a marriage piece.—Spence.]

Thomson and Mallet were both elueated at the university at Edinburgh. Thomson eame up to town without any certain view : Mallet got him into a nobleman's family as tutor; he did not like that afficir; left it in about three quarters of a year, and came down to Mallet at 'Twiford. There he wrote single winter pieces; they at last thought it might make a poem. It was at first refused by the printer; but received by another. Mallet wrote the Dedication to the Speaker.-Dodington sent his services to Thomson by Dr. Young; and desired to see him ; that was thought hint enough for another dedication to him: and this was his first introduetion to that aequaintance. They make him promises, but he has nothing substantial as yet. -Thomson's father was a presbyterian parson.-Wallet.

The Duke of Montague has an hospital for old cows and horses; none of his tenants near Boughton dare kill a broken-winded horse: they must bring them all to the reservoir.-The Duke keeps a lap-dog, the ugliest creature he could meet with : he is always fond of the most hideous, and says he was at first kind to them, because nobody else would be.-Dr. Clarke.

A great man (Dean Lockier) would not for several years keep any animal about him: He was afraid it would take up too much of his love. He had formerly kept a dog fourteen years, and was ashamed to say how much he was grieved for the loss of it.- $D r . C$.

Each step higher in the world, brings more dependance 
and more trouble upon a man. I have heard the Bishop of Winchester often say the same.-Di. $\mathrm{N}-$, Dean of Winton. [Both the dean and the bishop, however, still endeavour to rise as much as any men.-_ipence.]

" How could the Duke of York make my mother a papist?" said the Princess Mary to Dr. Burnet._-" The Duke eaught a man a-bed with her, (said the Doctor,) and then had power to make her do anything."--The Prince, who sat by the fire, said, "Pray, madam, ask the Doctor a few more questions." -Dean of Winton.

Bishop Ken went to Rome with Dr. Walton: part of his design was to inquire into the Romish religion, and if he found it sound, to profess it and eontinue at Rome. He returned about 1675 , after six years stay abroad. In King James's reign, upon his eomplimenting him on some passages in his writings for their nearness of opinions, he told the King, what little reason he had to do so: that he had been once inclined to his religion, but that the New Testament, and his journey to Rome, had quite cured him.The Bishop's persuading Zulestien, the morning they were going for the hunting in Westphalia, to marry the maid of honour he had debauched, was the cause of his disgrace with the Prince of Orange.-Mr. Cheyne.

Upon some lady eomplaining of the sufferings of women; Dr. Arbuthnot said, "Yes, the ladies suffer greatly in some particulars, but there is not one of you that undergo the torture of being shaved three times a week."-Mallet.

Monsieur de Montesquieu, the author of the Persian Letters, is now with Lord Waldegrave, and is to come to England with him: He says there are no men of true sense born anywhere but in England.-Mr. Brandreth. 
Monsieur de Voltaire says, that " the English plays are like the Englisle puddings: nobody las any taste for them but themselves."-Finshau".

$\Lambda$ common phrase for smuff among the Italians is, IIilarità del Naso.-P'rince Eugene used to take vast quantities of it, ont of his tin pocket, when he had given any orders and was most solicitons how to proceed-it helps meditation mightily.-.VIr. Baillerdeau.

Lang did the eighth or tenth book of the Odyssey, and Mr. Pope gave him a twenty-two guinea medal for it.Wilson, of Bulliol College.

There are no two things so much alike in nature as two kings.-CThere are none but the very first, and very last of men that are particularly miserable; and even in then, it is, if well consilered, frequently of their own seeking or by their own fault.—Di. King, of St. Mary Hall.

It is necessary, in many cases at least, to feign a warmth for party: where the mob are to be the judges. They have the fairest ehance for the majority, who have the most enthusiasm on their sile. You may lose your cause by resolving to appear ealm and reasonable.

Dr. Collet upon mistaking $\psi v \times n \alpha$ เo 05 in his author for audos, wrote in his notes, fifteen reasous to prove why the soul was like a flute.-Derham, of St. John's.

Farquhar died young: he improved in each play; his last was the best. Had he lived, he would probably have made a very good writer that way.-Oldisworth.

Creech* translated most of Lucretius in walking round

* From a letter of Dr. Ar. Charlett, in Ballard's Collection, quoted by Thomas Warton in his life of Bathurst, the cause of poor Creech's death is thus stated :- "There was a fellow-collegian, of 
the parks : fifty lines, perhaps, at a time, which he used to write down when he came to his chamber, and eorrect afterwards at leisure.-Mi. Pitt, from his father, who translated the Plague of Athens in the Poem.

I saw Mr. Dryden when I was about twelve years of age : -this bust is like him.-I remember his face well ; for I looked upon him, eren then, with the greatest veneration, and observed him very particularly.-Mi. Pope. This was not written down until 1730 , but certain.

I was aequainted with old men when I was young; which has brought some habits upon me that are troublesome.-Pope.

The Book of Job is, perhaps, the first dramatic piece that ever was written. It is evidently a tragedy, and the design of it is to show cur malis bone, et bonis male! Taken with that single precaution, it is very easily understood all through. The performance is very well for a young man.

whom Creech frequently borrowed money; but that repeating his applications too often, he met one day with a cold reception, and in a fit of gloomy disgust retired, and in three days was found hanging in his study."-In a letter of Bishop Tanner's to Dr. Charlett, cited by Mr. Malone from the same collection, it appears that he was probably insane: the passage is as follows, "I found out Mr. Creech yesterday, at Jacob Tonson's. He complained to me of a fever, that he had had upon him ever since his coming to town; which, and his want of habit, has hindered him from waiting on Dr. Wake; though I helieve it will not be hard to prove that he has been abroad every day. But I am very glad to hear that he is come to his senses again, and wish he may not relapse. I always feared that he would be mud at last : and the only way to prevent it, will be to help him to such preferment as his great merit deserves; for notwithstanding his failings, I can't choose but respect him, out of regard to his learning." MSS. Ballurd, in Bibl. Bodl. vol. iv. p. 26.-Editor. 
Bishop Hare, from Di. Comybeare. [The Bishop says, he would engage to prove it very plainly to have been written a little before Ezekiel's time.]

Lord Cowper, on his death bed, ordered that his son should never travel; (it is by the absolute desire of the queen that he does.) Ile ordered this from a good deal of observation on its effeets; he had found that there was little to be hoped, and much to be feared, from travelling. Atwell, who is the young lord's tutor abroad, gives but a very discouraging aceount of it too in his letters; and seems to think, that prople are sent out too young, and are too hasty to find any great good from it.-Dr. Conybeare.

Dr. Plot was very eredulons, and took up with any stories for his History of Oxfordshire.-A gentleman of Worcestershire was likely to be put into the margin, as having one leg rough and the other smooth, hat he not discovered the cheat to him out of eompassion; one of his legs had been shaved.-Mir. Hudson.

In the Iliad you are fully engaged in the part you are reading: in the Odyssey you are always wishing for the event; the latter is masterly in raising that appetite which is particular to romance: the other is full in each part:one, always affords the pleasure of expectation ; - the other, of fruition.-Di. Foreng.

The splendid fault of Lord Bacon and Malebranche is being too beautiful and too entertaining, in points that require reasoning alone.-There should be one character preserved in style, as much as in painting. In a picture, though each figure is dressed differently, and in so different colours, that they shall be all used variously in the piece; yet there is such a general air that at a distance you perceivo 
it to be one representation, the tints are so well managed. -Dir. $Y$.

Cicero has not full justice done him : he suffers with us by our comparing him with Demosthenes; who is more strong and less diffused, and so more agreeable to our present taste. Had Cicero lived in Demosthenes' time and country, he would have followed his manner, and vice versa.Nearly the same may be said of IIorace and Juvenal.-I believe it is true that Dryden gives the preference so much to Juvenal, because he had been just translating him.-Dr. $F$. 'Tis provoking that Dryden should give the preference to Persius too, for the same reason.-Mi. Reynel.

I think there are a great many fine eopies of verses in the Muse Anglicance.-Di. I. [He mentioned only Bathurst and Hannes.]

Swift, Steele, and Addison, are all great masters of humour. Swift had a mixture of insolence in his conversation.-Sir Richard Steele was the best-natured ereature in the world: even in his worst state of liealth, he seemed to desire nothing but to please and be pleased.-Addison was not free with his superiors.- He was rather mute in society on some occasions; but when he began to be company, he was full of viracity, and went on in a noble stream of thought and language, so as to chain the attention of every one to him. - I like his Campaign, though so many speak against it: he was undoubtedly a very good poet; but, after all, what will eary him down to posterity, must be his prose writings. - The love part in Cato was certainly given to the taste of the times; it is extremely cold and stiff: I believe he was so taken up with his chief character, 
which he has finished in so masterly a manner, that he negleeted the subordinate parts.-Dr. $Y$.

The portrait Mr. Pope has of Wyeherley, was drawn when he was very old: as Sir Godfrey Kneller said, he would make a very fine head without a wig; it was drawn at first with his little straggrling grey hair: he conld not bear it when done, and Sir Godfrey was obliged to draw a wig to it.-Mr. Saville.

The genteel manner of my Lord Oxford's present to Mr. Pope, is well worth recording.- - Ile seemed to have forgot some money due for subseriptions he had procured to the Homer (the amount about thirty guineas), some time after he sent a gold eup with the following inseription: Eitv : Comes Oron. Alex ro. Pope in memoriam Putris. The cup was worth about one hondred and fifty guineas; and he said he did not know the sum exactly, but thought it might be about what he ower him. The earl, his father, had never made Mr. Pope any present for his dedication: and Mr. Pope said he was perfectly right in not doing it, so that he is a man above presents in the eommon way.Dean Swift's little silver eup had the following inseription. Jonathan Suift Alex ${ }^{\text {ro }}$. Pope: Pignus Amicitice exigum ingentis.

Mr. Pope said one day to Mr. Saville: "If I was to begin the world again, and knew just what I do now, I would never write a verse."

I have seen, of Mr. Pope's drawing, a grave old Chaueer, from Oecleve; a Betterton; a Lueius Verus, large profile; two Turkish heads; a Janizary from the life; Antinous; and St. John praying.-Spence. 
After Mr. Pope was known to Wycherley, and began to be talked of in town, he had several poems to correct, though so young. His father begged him not to do it, "You'll do nothing (said he), but get enemies by it."-did not care for the office, but often could not well avoid it. -Mr. Mannick.

When the Prince of Orange was landing at Portsmouth he began to harangue the populace, and said, "We are come for your good, for all your goods." - Mr. Hooke.

Mr. Warburton is the greatest general eritic I ever knew, the most capable of seeing through all the possibilities of things.-Pope.

You have heard of the Kit Kat Club. The master of the house where the club met was Christopher Katt,* Tonson was secretary. The day Lord Mohun and the Larl of Berkley were entered of it, Jacob said he saw they were just going to be ruined. When Lord Mohun broke down the gilded emblem on the top of his chair, Jacob complained to his friends, and said that a man who would do that, would cut a man's throat. So that he had the good and the forms

* This society is said to have first met at an obscure house in Shire-Lane, and consisted of thirty-nine distinguished noblemen and gentlemen, zealously attached to the protestant succession in the House of Hanover : among whom were the Dukes of Somerset, Richmond, Grafton, Deronshire, and Marlborough, and (after the accession of George the First), the Duke of Newcastle, the Earls of Dorset, Sunderland, Manchester, Wharton, and Kingston: Lords Hallifax, and Somers. The club is supposed to have derived its name from Christopher Katt, a pastry-cock, who kept the house where they dined, and excelled in making mutton-pies, which always formed a part of their bill of fare; these pies, on account of their excellence, were called Kit Kats.-The summer meetings were sometimes held at the Upper Flask, on Hampstead Heath.Editor. 
of the society much at heart.-The paper was all in Lord Hallifax's hand writing, of a subseription of four hundred guineas for the encouragement of good comedies, and was dated 1709. Soon after that they broke up.-Steele, Addison, Congreve, Garth, Vaubrugh, Manwaring, Stepney, Walpole, and Pultney, were of it: so was Lord Dorset, and the present Duke. Manwaring, whom we hear nothing of now, was the ruling man in all eonversations, indeed what he wrote had very little merit in it.-Lord Stanhope, and the Earl of Essex were also members. Jacob has his own, and all their pietures, by Sir Godfrey Kneller. Each member gave him his, and he is going to build a room for them at Barn Elms.-Mr. Pope, 1730.

Mr. Pope said, "The story invented by Cibber was an absolute lie, as to the main point. He was invited by Lord W. to pass an evening with him; and was carried by him, with Cibber and another, to a bagnio; but nothing happened of the kind that Cibber mentions, to the best of my memory, and I had so few things of that kind ever on my hands, that I should have searee forgot so material a circumstance." $-P$.

I could give a more particular account of Mr. Pope's health than perhaps any man. Cibber's slander (of a carnosity) is false. He had been gay, but left that way of life upon his acquaintance with Mrs. B.-Mr. Cheselden.

The Critique on the Pastorals in the Guardian, was written by Mr. Pope himself, and commends Philips in such points as Mr. P. exceeds him in evidently, or else eommends

* There is a note by Mr. Spence on this passage, evidently written at the s:me time, which appears almost prophetic."Whether this may not be the ease with Lord Bolingbroke, when he has been gone as long?"-It has been the ease with that great demagogue, and Spence's surmise is verified.-Editor. 
him falsely, as for making his flowers all blow at one season.-Addison, and that party, then had a great desire of running Pope down.-Mr. Pope was sorry that his verses on Addison ever got abroad, they oceasioned him a good deal of trouble.-Lang.

What a run had Cowley's verses for about thirty years, the editions are innumerable.-There has been no edition now for this long time. He is no master of versification.Thomson's Winter is a huddled composition, and oftentimes not quite intelligible, yet he discovers the true spirit of poetry in him.-There are but three poets who have any constant great run of popularity now, Pope, Pryor, and Addison.-Mr. Harte.

The first volume of Robinson Crusoe was very popular, the proprietors eleared above a thousand pounds by it; and though the seeond sold off about two editions, yet the booksellers would have given two hundred pounds that it had never been printed, the first would have been so much more saleable withont it.-Mr. $H$.

Lord Oxford was no great seholar, and very ignorant of Greek, yet he took great delight in repeating hard Greek verses, and in talking a man down.-_Philips, being apprized of his weakness, after a bottle or two got the better of him, and $\mathrm{my}$ lord loved him the better for it ever after.-Lord Bolingbrolie.

The Duchess of Kendal often complained that her greatest difficulty was to find employment for the king's idle hours. - Mad. de Maintenon made the same complaint in regard to Louis the Fourteenth.-Lord Bathurst.

Some wicked wag had a stone engraved with rude unintelligible characters, corroded with vinegar and buried at 
Rome. At a proper interval of time, he took eare to have the place dug on some pretended oceasion by several workmen; and when the stone was found it was earried in triumph to the Pope. Kircher was sent for, who examined it, and said he might in time discover the meaning of the hieroglyphical charaeters upon it. In the sequel he wrote a whole volume upon it, and explained it notably. The Pope was let into the whole seeret, and poor Kireher suftieiently ridieuled. The Jesnits endeavoured to buy up the whole impression of the book, but some of them had got abroad, and are sometimes even now to be met with.- $\mathrm{Mr}$. Gibls.

I have read most of the Italian dramatic eompositions of any note, but am no great admirer of their theatre; neither is that kind of reading the properest for getting an insight into the beauties of their delightful language. Boeeaceio, Bembo, and Monsignor della Casa ought to be your partieular study; but by all means aroid Bentivoglio, his language is altogether frenehified, by his residenee at Brussels and Paris: and, though beautiful in its kind, yet far inferior to the others, who are all of the true Tusean dialect. After the three above mentioned, Guieciardini's History, and then their poets, who are full of beauties, but mixed with a terrible eontrast of concetti and epigrammatic points.-Dante, Petrarca, and Ariosto, themselves are full of surprisingly great and little things.-Ramsay.

The paintings of the aneients are exeellent for design, in the basso relievo way, but defieient in colouring. Their want of knowledge of chiaro-oscuro, and of variety in their colours, made them inferior in those respects : their design is juster, but often too stiff.-Raphael made his drapery too 
stiff, by imitating the ancient sculpture, and Bernini, latterly, made the drapery of his statues too large, heavy, and unbeeoming, by endeavouring to imitate the modern painters, partieularly Rubens, in stone.-Mr. Knapton, at Rome.

The Marquis of Blandford was not overwise; he was subject to great fits of laughter at the veriest trifles. Onec, upon Mr. R.'s filliping a piece of bread into a blind fiddler's face, it held him in an exeessive fit for half an hour; which returned whenever the thing was only mentioned afterwards. -Mr. Richardson.

There are two volumes in folio of King James's Memoirs in the library of the Seots college at Paris. The Marquis of Blandford, and three other gentlemen, stole the reading of one of them.-Mr. Penton.

Mr. Hooke used to say there were three reasons why a man would choose to live in England: liberty, liberty, liberty!

As it was a great while before the general Index to the Translation of Catrou and Rouille's Roman History could be published, Mr. Hooke thought of aftixing the contents to eaeh volume as they eame out. He at first intended only to have translated their summary: but found that so faulty, that he was forced to correct and add to it often. This carried him so far, that his contents began to look like a history; and led him at last to the design of writing his Roman history, which will be in two volumes in quarto.Mr. Hoolie.

$\mathrm{Mr}$. Hooke read some speeches of his Roman History to the Speaker Onslow, (who piqued himself too upon reading,) and begged him to give his opinion of the work: the Speaker answered in a passion, " he could not tell what to think of 
it, it might be nonsense, for aught he knew ; for that his manner of reading had bewitehed him.."-Richardson.

$\Lambda$ man who would be well acquainted with the Jewish Antiquities, should read the Cabala Reserata, Basnage, and the Mours des Israelites, by Fleury. He named Cumberland for the precepts of Noah; Spenser, though mistaken in the origin of sacrifices, exeeeding good; and Selden de Legibus Hebrcoorum, all useful to this end.-Ramsay.

Mr. Addison was not a good-natured man, and very jealous of rivals. Being one evening in company with Philips, and the Poems of Blenheim and the Campaign being talked of, he made it his whole business to run down blank-verse. Philips never spoke till between eleven and twelve o'clock, nor even then eould do it in his own defence. It was at Jacob Tonson's : and a gentleman in company ended the dispute, by asking Jaeob what poem he ever got the most by ?-Jacob immediately named Milton's Paradise Lost.-Dr. Leigh, who had it from the gentleman who was present.

Reynolds of Exeter, when at Eton, dreamed that his father was dead, and that he was walking in the meadows very melancholy; when a strange woman eame up to him, who told him that she was his mother, who died soon after he was born.- She said to him, "Yes, your father is dead, and your mother-in-law has had too much influence over him : he has left all his property to the younger sons; but there is an estate which he had no right to leave away from you : the writings are in Mr. ..... 's hands, go to him, and you may reeover it."-Reynolds having no news from home of this kind, soon forgot his dream. About a year after, he goes down to his friends, and finds his father very 
well; but he had been, at the very time of Reynolds's dream, extremely ill, and reeovered beyond expectation.The friends, to whom he related his dream, when he described to him the person of the woman who appeared to him, said they who had been well aequainted with her, could not have deseribed his mother's person more exactly. About a year after, his father fell ill again, died, and left all to his younger ehildren.-Upon this Reynolds's dream eame again into his mind: He goes to the gentleman named to him by his mother in that vision, and finds that it is exactly as he had been told, recovers the estate mentioned, and enjoys it at this day.-The Dean of Christchurch, 1726.

"Is Barelay's book in as great repute with you as it used to be?"-Yes.- " Is not the design of it to restore the religion of nature?" - Yes._- Does he mean only right reason, by the spirit, the word, and the light within us?" -No.-He means the influence of the Deity upon our minds : not right reason, but reason led ariglit.-Exaetly squaring with the original religion; and the most ancient opinion of our being guided and aeted upon always by the Deity.-Mrs. Drummond.* March 3 and 5, 1746.

"Where could one meet with the laws of Pennsylvania?" -They are not printed; but thon mayst meet with them at the Board of Ordnanee, where the original draught is kept.- " Is not your government here much like that of Pennsylvania?"-Exactly the same, allowing for our being

* Mrs. Drummond was a very celebrated person in her time, and is alluded to in the following passage of Pope's Epilogue to his Satires :

" A simple quaker, or a quaker's wife,

Outdo Landaffe in doctrine,-yea, in life." 
dispersed here, and being gathered into a body there.Mrs. D.

One of our teachers is going to publish a new translation of the Bible; from which we expect a good deal: he has laboured long for the original languages.-Mrs. D.

I aceompanied Mrs. Drummond to their meeting; she behaved with the greatest stealiness and seriousness. No whining when she spoke, and scaree any action. Very good langnage; prartieularly full of metaphors, but pretty and well managed ones: rather a general diseourse, than any one subject pursued: and accordingly the proposition was made, not at the beginning, but at the conclusion.- " That we may all endeavour to amend our lives, and to be always ready for this great ehange; is the earnest desire of my heart, and the design of my present exhortation."-'Then another preached; and then she made a prayer (at which they all stood up, with their hats off) with good language, and with a good deal of derotion: and, among other things, beg'ged, " that God wonkl enlighten the eyes of those who were at all inelined to see the truth; and bring them fully and heartily to embrace it." - She sat at the lead of the elders, in the lighest line: there was a row, under all, of women preachers: (three only spoke while I was there; and those all women.) There was above half an hour's silence in the beginning: for that " leep attention, dc." which she spoke of. The people on the speaking benches seemed more particularly moved, both then and afterwards. Some of them had a great deal of tranquillity in their looks, some were quite impassioned, some looked sullen; but the more general air, especially in the congregation, was that of drowsiness. One of the 
women on the preachers' seat, had a constant gentle agitation of the head. Another, who seemed extremely pretty when she came in, grew quite ugly before I eame out. Her colour, whieh was very fresh at first, sunk gradually till she was quite pale; her lips grew livid; her look wan, and somewhat ghastly; her eyes lost all their lustre; and the air of her face all its pleasingness. So that quakerism is by no means a proper religion for the pretty women of this world; at least if they think of sitting on the beneh of the preachers; or should affect to appear strongly moved, with the supposed influenees which they sit to receive in their congregations.-Spence.

The false leaf of the Duneiad sent to Cibber, as stolen from the printer's by a friend, mentions the story about Mr. Pope in Cibber's letter, and insinuates that Gay was of the party, and that Cibber, breaking in upon Mr. Gay's privacy, found him in company with his own daughter, and therefore pulled him away._Cibber, Jan. 10, 1748.

Mr. Pope brought some of the " What d'ye call it," in his own hand writing to Cibber, the part about the miscarriage in partieular, but not mueh beside. When it was read to the players, Mr. Pope read it, though Gay was by. -Gay always used to read his own plays. After this, upon seeing a knife with the name of $J$. Gay upon it, Cibber said; "What, does Mr. Pope make knives too?"- $C$.

Cibber confirmed to me Mr. Addison's character of bearing no rival, and enduring none but flatterers. And said that he translated the greater part of the first book of the Iliad, published as Tiekel's, and put it forth with a design to have overset Pope's.-Spence.

"I am for the church, though I don't go to church," 
(said he,) to illustrate his loving virtue in a play, \&c. thongh he did not practice it.-Cibber.

On learing the "Fair Foundling" read, he excused himself for finding such little faults, beeause there were no great ones in it: he called it immoderately good, and said he had not seen so good a play these fifteen years. $-C$.

Sir John Vaubrugh left only a sketeh of the " Journey to London ;" how much Cibber did appears by the ébauche printed.-C.

Mr. West told me his piece on the Resurreetion, was written down only for his own satisfaction: he had no design of making a book of it; and thought it would have been only a sheet or two.-Dr. Shaw wrote to Mr. Lyttleton, to let him know that the university were inclined to give him and Mr. West the Doctorate. Mr. Lyttleton, as his name was not to his piece, exeused himself; West had not the same excuse, so they sent him his diploma for it.-Mr. West has translated three or four Odes of Pindar, beside the twelve he is publishing.-Pindar is not so irregular, nor so abrupt as he has been gencrally imagined. Most of his hymns were sung in processions or triumphs; and eateh at the aetions performed on parts of the ground they passed by, \&e.-His first Pythian, the best of them all: he is a very moral poet.-Mr. West seems inclined to more serious studies; and quoted Horace's " Nimirum sapere est abjectis utile Nugrs,"-with a stronger aceent.

Doctor Swift gave Mr. Coote, a gentleman of very good character and fortune, a letter of recommendation to Mr. Pope, conclied in the following terms:- " Dear Pope, though the little fellow that brings this, be a justice of peace, and a member of our Irish House of Commons; 
yet he may not be altogether unworthy of your acquaintance."-Mr. Jones, of Welu'yn.

It was the Marquis of Wharton who first got Addison a seat in the House of Commons; and soon after earried him down with him to Winehelsea. Adlison was elarmed with his son, (afterwards Duke of Wharton,) not only as his patron's son, but for the uneommon degree of genius that appeared in him. He used to converse and walk often with him. One day the little lord led him to see some of their fine running-horses; there were very ligh gates to the fields, and at the first of them, his young friend fumbled in his poekets, and seemed vastly eoncerned that he could not find the key. Addison said 'twas no matter, he eould easily climb over it. As he said this, he began mounting the bars, and when he was on the very top of the gate, the little lord whips out his key and sets the gate a swinging, and so for some time kept the great man in that ridieulous situation.-Di. Young.

At that time of life when the, Duke of Wharton's most vehement ambition was to shine in the House as an orator, he found le had almost forgotten his Latin, and that it was necessary, with his present views, to reeover it. He therefore desired Dr. Young to go to Winchenden with him; where they did nothing but read Tully, and talk Latin for six weeks:- at the end of whieh, the duke talked Latin like that of Tully. The doetor on some other oceasions, as well as this, ealled him a truly prodigious genius.-D Dr. $Y$.

William Harrison, the son of Dr. Harrison, master of St. Cross near Winehester: was edueated at the college there, and sueeeded to New College, Oxford. He was so 
very ready at that extempore sort of versification* much used in Winchester school, as to improve and influence the manner of it in his time and for years after.-He wrote a satire on the ladies of Winehester, whilst at sehool, and his Woodstock soon after; on which Addison said, " this young man, in his rery first attempt, has exceeded most of the best writers of the age."-Addison recommended him to be tutor to a young nobleman, and it was soon after that he said to him, " we who have gone through a good school education, may easily enough get to be good classieal scholars; but there is one thing I would now advise you to, -read a good History of England, that you may know the affairs of your own country :" and he immediately began

* He had a sweetness of versification in these even beyond that of Ovid. Dr. Young remembered some lines on a woman debauched by presents, who repented afterwards, and died of grief.

Obruitur donis accumulata suis.

Oldisworth had great fluency; and would repeat twenty or thirty verses at a heat; but they were not remembered generally, as Harrison's were.-Spence. Mr. Harrison was author of the Medicine, a Tale in No. 2. of the Original Tatler, and of some poems which may be found in Dodsley's and Nichol's collections. Swift seems to have been very partial to this amiable young man, and says of him, in a letter to Stella, dated Oct. 13, 1710.- " There is a young fellow here in town we are all fond of, and about a year or two from the university, one Harrison, a little pretty fellow, with a great deal of wit, good sense, and good nature."-When Steele discontinued the Tatlers, Swift advised Harrison to continue them, promising him assistance. Harrison published about fiftytwo numbers, and hal the aid of Cungreve, St. John, and Henley; these papers were collected and entitled a fifth volume of the Tatler, but are for the most part very inferior to the papers of $\Lambda$ ddison and Steele. 
to follow this piece of good advice. Addison recommended him to Lord Strafford as Secretary to the Plemipotentiaries* for the treaty of peace at Utrecht. When he came over with the Barrier 'Treaty he went to court very richly dressed, on a birth-night within a month after his return: caught a violent cold there, which brought on a fever that carried him off. He was a little brisk man, quick, and passionate; rather foppish in his appearance, a pretty look and quick eye. His family were all handsome.-Dr. $Y$.

On my saying that old Cato in Cicero's delightful Treatise on Old Age, mentioned planting as the greatest pleasure for it.-Dr. Young observed that he thought he could men-

* The income of the secretary ship was to have been one thousand pounds a year, but Harrison received nothing, and when he returned to England was three hundred pounds in debt, and without a shilling. In a letter to Stella (Jan. 31, 1712), Swift says, " Harrison was with me this morning, we talked three hours, and then I carried him to court. When we went down to the door of my lodgings I found a coach waiting for him. I chid him for it; but he whispered me, it was impossible for him to do otherwise; and in the coach he told me, he had not one farthing in his pocket to pay for it; and therefore $t_{1} \mathrm{ok}$ the erach for the whole day, and intended to borrow money somewhere or other. So there was the queen's minister, intrusted in affairs of the greatest importance, without a shilling in his pocket to pay a coach."-In the journal to Stella, the illness and death of poor Harrison are recorded in terms which do much honour to the heart of Swift.-February 12, 1712-13. "I found a letter on my table last night, to tell me that poor little Harrison was ill, and clesired to see me at night; but it was late, and I could not go till to-day. - I went in the morning, and found him mighty ill, and got thirty guineas for him from Lord Bolingbroke, and an order for an hundred pounds from the treasurer to be paid him to-morrow; and I have got him removed to Knightsbridge for the air. He has a ferer and inflammation on the lungs, but I hope will do well."-13th, "I was to see a poor poet, one Mr. Diaper, in a nasty garret, very sick. I gave him 
tion a greater:- the looking back on a life well spent.Spence.

Tonson and Lintot were both candidates for printing some work of 1)r. Young's.-He answered both their letters in the same morning, and in his hurry misdireeted them.When Lintot opened that which came to him, he found it begin, " That Bernard Lintot is so great a scoundrel, that, \&c." - It must have been very anusing to have seen him in his rage, he was a great sputtering fellow.-Di. Young.

Lord Bolingbroke's father said to him on his being made a lord, " Ah, Harry, I cver said you would be hanged, but now I find you will be beheaded."-Dr. $Y$.

twenty guineas from Lord Bolingbroke, and disposed the other sixty to two other authors, and desired a friend to receive the hundred pounds for poor Ilarrison, and will carry it to him tomorrow morning. I sent to see how he did, and he is extremely ill; and I am very much afflicted for him, as he is my own creature, and in a very honourable post, and very worthy of it. I am much concerned for this poor lad. II is mother and sister attend him, and he wants nothing." -14, "I took Parnell this morning, and we walked to see poor Harrison. I had the hundred pounds in my pocket. I told Parnell I was afraid to knock at the door; my mind misgave me. I knocked, and his man in tears told me, his master was dead an hour befure. Think what a grief this is to me! I went to his mother, and have been ordering his funeral, with as little cost as possible, to-morrow at ten at night. Lord Treasurer was mucb concerned when I told him. I could not dine with Lord Treasurer, nor anywhere else; but got a bit of meat towards evening. No loss ever grieved me so much: poor creature!"-15th, "At ten this night I was at poor Harrison's funeral, which I ordered to be as private as possible. We had but one coach with four of us; and when it was carrying us home after the funeral, the braces broke, and we were forced to sit in it, and have it held up, till my man went for chairs, at eleven at night, in terrible rain. I am come home very melancholy, and will go to bed."-Editor. 
I'll send you my bill of fare said Lord B. when trying to persuade Dr. Swift to dine with him.- " Send me your bill of company," was Swift's answer to him.-Dr. $Y$.

Colonel Brett was a partieular handsome man. The Countess of Rivers looking out of her window on a great disturbance in the street, saw the eolonel assaulted by some bailiffs, who were going to arrest him. She paid his debt, released him from their pursuit, and soon after married him. When she died, she left him more than he expeeted; with whieh he bought an estate in the country, built a very handsome house upon it, and furnished it in the highest taste. Went down to see the finishing of it, returned to London in hot weather, and in too much hurry; got a fever by it, and died.-Nobody had a better taste of what would please the town; and his opinion was much regarded by the actors and the dramatic poets. $-D r . I$.

Mr. Pope desired Dr. Young to forward five guineas to poor Savage, when he was in Newgate for the death of Sinelair; the doetor was so good as to earry it himself: and Mr. Pope afterwards told him that if Savage should be in want of necessaries, he had five more ready for his service. $-D r . Y$.

"Why do you refuse the wine to the laity?"-Why, in proeess of time it was found that there were several ineonveniences in allowing it to them, (spilling the wine giving some offenee, de.) whieh our Saviour did not foresee, at the time of its institution; and so the ehureh was foreed to remedy it afterwards.-The Curé ***, at his Bastide near Nice.

My grandfather Englefield, of White Knights, Oxfordshire, was a great lover of poetry and poets. He was ae- 
quainted with Mr. Pope, and admired him highly. It was at his house that I first used to see Mr. Pope.- " It was after his Essay on C'riticism was published?"-Oh yes, sir. -I was then a very little girl, my uncle used to say much of him, but I did not attend to it at that time.- " I Iad he not a great deal of life and vivacity in his eonversation then ?" -Yes, it was quite surprising.-Mr. Pope used always to speak of his father as the best of men. He was a merehant that dealt in Ifollands; and left off business when King William eame in ; he was then worth ten thonsand pounds, but did not leave so much to his son.-Mrs. Blount.*

Everybody thought Mr. Pope worth a great deal more than he left behind him. What was over, after paying legaeies, de. did not amount to two thousand pounds, (beside the thousand pounds left to her, and mentioned in the will.) He did not know anything of the value of money; and his greatest delight was in doing good offices for his friends. I used to know, by his particular vivaeity, and the pleasme that appeared in his face, when he came to town on such errands, or when he was employed on them, which was very often.-Yon knew his mother, and how good a woman she was._Lis. B.

I had never read his will; but he mentioned to me the part relating to Mr. Allen, and I advised him to omit it,

+ This is the celebrated favourite of Pope, Martha Blount; she is called Mrs. here, though unmarried, according to the custom of that period.-Editor. [Mr. Pope had about three or four thousand pounds from his father, as I have heard him say. He had two or three thousand pounds out on annuities, for his life, with friends. My first acquaintance with him was after he had begun the Iliad.] -Mrs. Blount, from MS. B. 
but could not prevail on him to do so. I have a letter of his by me on that subject.-I sent it to Mr. Hooke.Mrs. B.

I have heard him speak of some work of Lord Bolingbroke's, which that lord designed to suppress : he spoke of it as too valuable to the world to be so used; and said he would not suffer it to be lost to it.- She had immediately the same thought relating to that affair, that I had: and said " she could take her oath it was done out of his excessive esteem for the writer and his abilities: but what signifies my words, or thoughts of that matter?-Mr. Pope was apt to be duped into too high, or too good an opinion of people, from the goodness of his own heart, and his general humanity."-Mirs. Blount, May 18, $17+9$.

[May 27, 1749. I read over the parts of the conversations that related to Mr. Pope's life and character to Mrs. Blount, and had several things confirmed, and some few eorrected and altered in the book itself.-Spence.] Speaking of the Allens, she said: "They had often invited me to their house; and as I went to Bristol with Lady [Gerard] for some time, while Mir. Pope was with them, I took that opportunity of paying the visit they had desired.-I soon observed a strangeness of behaviour in them. They used Mr. Pope very rudely; and Mr. Warburton with double complaisanee, (to make their ill-usage of the other more apparent;) me they used very oddly, in a stiff, and overeivil manner.--I asked Mr. Pope, after I had been there three or four days, whether he had observed their usage of him.- Ife said he had taken no notiee of it; but a day or two afterward he said, " that the people had got some odd thing or other in their heads." - This oddness continued 
(or rather increased) as long as we stayed. Some time after, Mr. Allen eame to London; and I asked Mr. Pope whether he had erer inquired into the eause of their behaviour. Ite hat not; and I urged him to clear it up. In urging this, I used the word satisfuction. Mr. Ilooke, who was by, took this in the genteel sense of the word, and imagined I would have had Mr. Pope fight Mr. Allen: which I declare was not the least in my thoughts.-It was this which Mr. II. gave as the cause of his estrangement from Mrs. Blount, to herself. All she wanted to know was, why they were so used.** His. $B$.

* Ruffhead states that, " $\Lambda$ bout a year before Mr. Pope's death, this lady, at the desire of Mr. Pope and Mr. Allen, paid a visit at Prior Park, where she behaved in so arrogant and unbecoming a manner, that it occasioned an irreconeileable breach between her and some part of Mr. Allen's family. As Mr. Pope's extreme friendship and affection for Mrs. Blount made him consult her in all his concerns, so when he was about making his last will, he adrised with her on the occasion; and she declared to him, she would not aecept the large provision made by it for herself, unless he returned back, by way of legacy, all that he had received of Mr. Allen, on any aecount: and Mr. Pope, with the greatest reluctance, complied with the infirmity of such a vindietive spirit. -It is certain that Mr. Pope, in this, as in the case of Lord Bolingbroke, deserred pity instead of blame. For though he had the strongest friendship and affection for Mrs. Blount, yet it was of a kind the most innocent and pure, notwithstanding what malignant or mirthful people might suggest to the contrary, either in jest or earnest. But no exeuse can be made for Mrs. Blount's abuse of the influence she had over him; or for the indifference and neglect she showed to him throughout his whole last illness." Dr. Warton and Dr. Johnson state the eause of the quarrel to have been, Mr. Allen's refusal to lend Mrs. Blount his coach to carrs her to mass at Bath, during his mayoralty.-From the above account, and the letters of Pope to Mrs. Blount on this occasion, it appears most probable that the quarrel lay between MIrs. Allen 
I have a letter of Lord Bolingbroke's by me, in which he speaks of Mr. Pope as one of the greatest and the best of men.-Mrs. $B$.

and Mrs. Blount. These letters, which throw much light on the mysterious connexion between the poet and his mistress, are printed in the tenth volume of Mr. Bowles's edition.-Though Pope determined on never setting foot more in Mr. Allen's house, he kept up a friendly intercourse to the time of his death, and besides the pettish legacy, left him his library.-_" Mr. Allen accepted the legacy, as Mrs. Blount was the residnary legatee, but gave it to the Bath Hospital; observing, that Pope was always a bad accountant, and that if to one hundred and fifty pounds, he had put a cipher more, he had come near the truth."-Editor. 


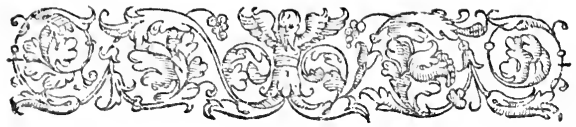

\section{SUPPLEMENTAL ANECDOTES.}

\section{FROM FIRST MEMORANDUM BOOK}

FOR 1755.

resterne reading of novels and eastern tales, \&c. a drinking of drams. - Wine tastes like water after the latter; and the daily occurren of life seem quite tasteless and insipid after being deeply engaged in the former.-Spence.

The necessity of reading books obvious; for among the Turks, where reading is but little in use, they are obliged to use opiates to make them less sensible of the tedium of listless leisure.-Spence.

The brighter evergreens, which are the shades in summer, are the lights in winter.- IIow much worse those two forward urns look, than the two next, beeause they have no foliage to back them.- When the whole plan of a garden is visible at one glance of the eye, it takes away even the hope of variety.- $\mathrm{Vr}$. Southcote.

Benevolenee is more of a passion, than a virtue in me ; and ought to be watched almost as much as a vice; to keep it either from impertinence or impropriety. - Spence. 
Facardin's garden, in Count Hamilton's tale, a good deal like the deseription of Aleinous's, in Maundrel's Travels, p. 39.-The gardens of Damasens were numerous and well watered, p. 122, 128, 130. Maundrel was on Mount Lebanon, and mentions a tree of twelve yards six inehes in girth, p. 142.-Spence.

Sir Isaae Newton's house at Coldsworth is a handsome structure.-His study boarded round, and all jutting out. We were in the room where he was born. Both of as melancholy and dismal an air as ever I saw. Mr. Percival, his tenant, who still lives there, says he was a man of very few words; that he wonld sometimes be silent and thoughtful for above a quarter of an hour together, and look all the while almost as if he was saying his prayers: but that when he did speak, it was always very much to the purpose.May 14, 1755.-Spence.

The pretty close, with the winding stream and spring, which we passed, is enlled Bucely.-The river Witham has its somree (at a town of the same name) about two miles S.W. of Coldsworth: it is fed by a number of springs from Sir Isaae's hill ; and meanders on (by Mr. Cholmondeley's and the Poltons) to Grantham; and goes by Lincoln and Boston into the sea. You pass elose by one of these springs as you go to the honse where Sir Isaae was born; with two or three ash trees, and hawthorns, about the head of it. [I would place rock work and seats there, with the following inseription: "s. StMMo IN TERRIS INTELLigeNTIE FONTI QUI PAULO SLPRA HAS SCATURIGINES EXORTUS EST sub forma homints nomine Isaacus Newton."] There are some of the family buried in the ehurehyard.- " In memory of Joln Newton, sen. 1725, xt. 53; and John 
Newton, jun. 1737, at. 30." The latter of these, perhaps, the consin to whom he left his estate there; and who run so entirely out of it, that he would have come to the prarish, had he not died in so good time as he dil.-Dial on the little arbour by the churchyard; "Sie transit gloria mundi." - Applied everything there to Sir Isane.-Spence.

Dr. Warburton compared Jackson, the metaphysical part of whose works were written by Clarke; and Waterland, who borrowed so largely from Bull; to the two broom-sellers: one stole his materials, the other stole brooms realy made.

He had onee a very full and free conversation with Mr. Pope, about changing his religion : * the perseeution allowed and followed so much by the ehureh of Rome, he owned looked like the sign of a false church.-The Dr. said; "Why then should you not conform with the religion of your country?"-He seemed, in himself, not averse to it, and replied, "There were but two reasons that kept him from it: one, that the doing so would make him a great many enemies; and the other, that it would do nobody else any good."-Dir. Warburton.

Mr. Pope was offered a very considerable sum by the Ducliess of Marlborough if he would have inserted a good character of the duke; - and he absolutely refused it.Real his character of the Duchess of Marlborough to her, as that of the Duchess of Buekingham; but she spoke of

* Mr. Pope, in his answer to the Bishop of Rochester, says, " that when he was a boy he read over the controversy of James the Second's time; that his father had them all, and that they were the only books he had in the country; and that the effect of it was, that he was a Papist or a Protestant by turns, according to what bouk he read last."-Spence. 
it afterwards, and said she knew very well whom he meant. -Dr. W.

In the Satire on Women there was a eharacter of the old Duehess of Marlborough, under the name of Orsini, written before Mr. Pope was so familiar witl her, and very severe.-Wis. Arbuthinot, 17t4.

There are several lines of Mr. Pope's in Gardiner's translation of Rapin's Poem on Gardens: and many of Dryden's in Sir W. Soames's translation of Boileau's Art of Poetry.-Dr. W.

Speaking of my attachment to Mr. Pope, the Dr. said, " he deserved all that love from you; for I am sure that he loved you very mueh: and I have heard him say so often and with great warmth." $-D r . W$.

He mentioned Mr. Pope's being so busied a few days before we lost him, in drawing up arguments for the immortality of the soul. (In a fit of delirium, he rose at four o'clock, and was found in his library writing; he had said something about generous wines helping it; whereas spirituous liquors served only to mortalize it.) $-D r$. W. from Hooke.

Hooke endeavoured to make a Roman Catholic of the Duchess of Marlborongh; (he thought she was going off, and would be willing to eatch at any twig,) and that was the occasion of her breaking with him. After all, he bimself is only an odd sort of Catholie, in his own (mystic) way.*-Dr. $W$.

* The Duchess of Marlborough was desirous of having an account of her public conduct given to the world. Hooke was re. commended to her, by Mr. Pope and others, as a proper person to draw up this account under her own inspection; he performed this work so much to her grace's satisfaction, that she talked of 
The Duke of Marlborough's character, intended for the Fourth Epistle of the Essay on Man, I never transcribed but for one very great personage.-Dr. $W$.

Mr. Pope was very angry with the vicious part of mankind, but the best natured man otherwise, in the world.Dr. W.

The Episode on his Daneing-Master, and all the fragments of the Memoirs of Seriblerus, are destroyed.-Dr.W.

It is perhaps singularly remarkable in Mr. Pope, that his judgment was stronger than his imagination when he was young. (Witness his Windsor Forest, and Essay on Critieism, produced at that period.) His imagination stronger than his judgment when he grew old, and produced the Essay on Man.- This plainly shows that the interclouding of his mind, was wholly owing to the weakness of

rewarding him largely, but would do nothing till Mr. Pope came to her, whose company she then sought all opportunities to procure, and was uneasy to be without it. He was at this time with some friends, whom he was unwilling to part with, a hundred miles distant. But at Mr. Hooke's earnest solicitation, when Mr. Pope found his presence so essentially coneerned his friend's interest and future support, he broke through all his engagements, and in the depth of winter, and ill ways, flew to his assistance. On his coming, the duchess secured to Mr. Hooke five thousand pounds, and by that means attached him to her service. But soon after she took occasion, as was usual with her, to quarrel with him.

" Her every turn by violence pursu'd

Not more a storm her hate than gratitude."

Thus Mr. Ilooke represented the matter.-The reason she gave of her sudden dislike to him, was his attempt to pervert her to Popery. This is not without probability : for he finding her grace without religion, (as appears from the "Account of her Conduet,") might think it an act of no common charity to give her his own.-Rufthead's Life of Pope, p. 490. Note. 
his body; (and is very agreeable to what we saw of him in his last month.) - It was very observable, during that time, that Mrs. Blount's coming in gave a new turn of spirits, or a temporary strength to him.-Dr. W.

Compassion (according to its very name) is nothing but a passion; and may lead one to do what is wrong, as much as aversion, hatred, or anger.-Spence.

\section{SECOND MEMORANDUM BOOK, 1756.}

Trie Duehess of Portsmouth, when she was in England in 1699, told Lord Chancellor Cowper, that Charles the Second was poisoned at her house, by one of her footmen, in a dish of chocolate.-Deen Cou'per.

When Sir Isaae Newton was asked about the continuance of the rising of South Sea Stock?-He answered, " that he eould not calculate the madness of the people."-Lord Radnor.

A friend once said to him, "Sir Isaae, what is your opinion of poetry ?"-His answer was; "I'll tell you that of Barrow; - he said, that poetry was a kind of ingenious nonsense."-Lord $R$.

By a very obrious and natural mistake in spelling, councillors become conecalers; lawyers, are liars; and justices, just-asses.-Mr. Robins.

The following inseription is on a church at Vicenza, dedicated to the Virgin Mary:- "Salve Mater Pietatis; et totius Trinitatis nobile Triclinium."-Mr. Massingberd. [This was confirmed by Dr. Lowth. "The noble couch 
for all the Trinity to recline upon."-Under the bust of the builder of a convent in Placentia, "Vir fuit ista domus quod conditor indieat ejus."]-Spence.

Mr. Pope was with Sir Godfrey Kneller one day, when his nephew, a Guinea trikler came in. "Nephew, (said Sir Godfrey, you have the honour of seeing the two greatcst men in the world."-_" I don't know how great you may be, (said the Guinea-man,) but I don't like your looks: I have often bought a man, mueh better than both of you together, all museles and bones, for ten guineas." $-D r$. Warburton.

Pope was mueh shoeked at overhearing Warburton and Hooke talking of Lord Bolingbroke's disbelief of the moral attribntes of God. "You must be mistaken," sail he. Pope afterwards talked with Lord B, about it, and he denied it all.-Sometime after Pope told his friends of it with great joy, and said, "I told you, I was sure, you must be mistaken." $-D i . W$. (He mentioned this as a proof of Mr. Pope's exeessive friendliness to Bolingbroke.)

Lord $\mathrm{B} * * * *$ was overeome with terrors and excessive passion in his last illness.-After one of his fits of passion, he was overheard by Sir IIenry Mildmay, complaining to himself and saying, "What will my poor soul undergo for all these things?"- $D r . W$.

When the Prince of Wales was at Mr. Allen's, near Bath, on seeing a pieture of Mr. Pope, he mentioned the cireumstance of his printing those pieces of Lord Bolingbroke, and said he supposed he was not in any fault in doing it.-Dr. Warburton, who was present, showed, in part,

* This is related in somewhat different terms in Ruffluead's Life of Pope, p. 219.-Editor. 
that he was not; - what he said was strengthened by Mr. Allen, and allowed to be just by Lord Bathurst, who eame with the prince.-In the original copy of those pieces, there were some things very severe on the king; which Mr. Pope, in concert with Lord B., omitted when they were printed: but he omitted nothing but what was agreed to, and inserted nothing.-Dr. Wr.

Socinus and Crellius were very good men, and meant well; the late recovery of reasoning then, made them carry it too far: but the modern Socinians, I fear, are not Christians; and pay only that sort of respect to Christ, which they might to Socrates.-Dr. W.

Lord Bolingbroke's "Occasional Writer" (the first stroke in his long continued pursuit against Walpole) is one of the best things he ever wrote- $-D r . W$.

Christianity seems to have received more hurt from its friends than from its enemies. By their making things parts of it, which are not so; or talking of things as very material to it, which are very little so.-Dr. $W$.

A very wise man will always have sense enough to see he is a great deal of a fool ; but a very fool always looks upon himself as a very wise man. (Madmen, Idiots, and nineteen-twentieths of the rest?)

When a thing is near one, and one wants to know what it is, it looks indistinct enough to be painful to one, even at a hundred yards distance. When a prospect extends very widely, there are objects that are pleasing even for being indistinct, perhaps one hundred miles off.-Spence.

"Why she and Phryne all the auction buys :

Phryne expects a general excise."

This was said of Lady Mary Wortley, and Miss Skirret. 
The note upou Justinian and Teonora meant at her. And the story to Lady Bath, turns upon lier so strongly, without her perceiring it.- Dr. Wr.

The happiness of life is so nice a thing, that, like the sensitive plaut, it shrinks away even upon thinking of it. - Spence.

How muth Dryden was in the wrong in thinking the Black Prince's recovery of Castile for Pedro the Cruel, from Ienry the Liberal, a fine subject for an Epic poem. The passage of the Pyrenees, and the battle of Najarra, are the only material subjects in it. Was he for Pedro, as Carte is, beeause he was a jure divino tyrant? - Spence.

It is an excellent rule! " That when a person does not understand Greek, he should seareh for the etymology of a word in some language which he does understand." Thus some of the Popish priests, learned in Latin, derive the word heretic, from evro and recto, because he errs from what is right! Others from the word eveiscor, a word in the civil law for dividing: and others again from adhereo, or adhering, because a heretic adheres obstinately to his error. See Geddes's Traets, vol. i. p. 391.-Spence.

Could Montaigne's Essays give a hint to our Tatler? He begins several of them with a quotation from the Classics, and chats on at his case. A couple of good Tatlers takeable from ehap. 19, lib. i. "on Death."Spence.

What a singular book is "The business of the Saints in Heaven," by father Lewis IIenriquez: printed at Salamanca in 1631. He attempts to prove, in the twentysecond chapter, "That every saint shall have his particular house in heaven; and Christ a most magnificent palace! 
That there shall be large streets, and great piazzas, \&e." -He says in the twenty-fouth ehapter, "That there shall be a sovereign pleasure in kissing and embracing the bodies of the blest; that there shall be pleasant baths, and that they shall bathe themselves in each other's sight. That they shall swim like fishes; and sing as melodiously as nightingales, \& c." - He affirms, in the forty-seventh chapter, "That the men and women shall delight themselves in masquerades, feasts, and ballads:"-and in the fiftyeighth, " That the angels shall put on women's habits, and appear to the saints in the dress of ladies, with curls and locks, waistcoats and fardingales, de." See the "Moral practice of the Jesuits," by the doctors of Sorbonne; it has been translated into English, and published in 1671.Spence.

As a probable falsehood is fitter for the drama than an improbable fact. So the appearance to the eye, is to be more followed in gardening than the reality of forms, where advantage is to be had by so doing.-Spence.

\section{THIRD MEMORANDUM BOOK, 1757.}

Thar education, and that politeness, are good for nothing, which do not make a man more knowing, and more pleasing. -Spence.

When Dioclesian had quitted the Imperial purple for some time, and they came to petition him to resume it, (on account of the necessities of the state:) "You could not have asked such a thing of me," said he, " had you seen 
the delightful plantations I lave made about my villa, and the fine melons that 1 have now ripening." see Montaigne, lib. i. cap. 41.-Spence.

Zalenens ordered that none but scoundrels should wear Mlilesian stutt's, dre., instead of making a law direetly against them. Diol. Sie. lib. xii. eaj, 20.-Spence.

If a common man should lose his capaeity of judging and thinking, he would lose a thing of very little extent, and if the wisest of men were to lose his, he would lose a thing of no great extent. A finishing stroke of the palsy should be looked upon, by a good man, as a coup de grace, that relieves him from the wearisomeness and tortures of a long death-bed siekness.-Spence.

Voltaire, like the French in general, showed the greatest complaisance outwardly, and hat the greatest contempt for us inwardly. He consulted Dr. Young about his Essay in English, and begged him to eorreet any gross faults he might find in it. The Doctor set rery honestly to work, marked the passages most liable to censure; and when he went to explain himself about them, Voltaire could not avoid bursting out a laughing in his face.-Di. Young.-[It was on the occasion of Voltaire's critieism on the episode of Death and Sin, that Dr. Young spoke that couplet to him-

"Thou'rt so ingenious, profligate, and thin, That thou thyself art Milton's death and sin."

* Acording to Mr. Gibbon, Dioclesian gave the following memorable answer to Maximilian, who invited him to re-assume the reins of government: "If I could show you the cabbages I planted with my own hands at Salona, I should be no longer urged to relinquish the enjoyment of happiness for the pursuit of power."-Editor. 
Voltaire's objection to that fine episode was, that death and sin were non-existents.-Spence.

Ambrose Philips was a neat dresser, and very vain.In a conversation between him, Congreve, Swift, and others, the discourse ran a good while on Julius Cæsar. After many things had been said to the purpose, Ambrose asked what sort of a person they supposed Julius Cæsar was? He was answered, that from medals, \&e., it appeared that he was a small man, and thin-faced.- " Now, for my part," said Ambrose, "I should take him to have been of a lean make, pale eomplexion, extremely neat in his dress; and five fect seren inehes high:" an exact deseription of Philips himself. Swift, who understood good breeding perfeetly well, and would not interrupt anybody while speaking, let him go on, and when he had quite done, said ; "And I, Mr. Philips, should take him to have been a plump man, just five feet five inches high; not very neatly dressed, in a black gown with pudding-sleeves." $-D r$. Young.

Congreve was very intimate for years with Mrs. Bracegirdle, and lived in the same street, his house very near hers; until his aequaintance with the young Duchess of Narlborough. He then quitted that house. The dnehess showed me a diamond necklace (which Lady Di. used afterwards to wear) that cost seven thousand pounds, and was purchased with the money Congreve left her. How mueh better would it have been to have given it to poor Mrs. Bracegirdle.-Di. Young.

Lord Granville had long wanted to pass an evening with Mr. Pope: when he at last did so, Mr. P. said that the two hours were wholly taken up by his lordship, in debating 
and settling, how the first verse in the Eneid was to be pronouneed: and whether we should say Cicero or Kikero! This is what is meant in the two lines inserted in the Duneiad, on those learned topies.-Dr. Warburton.

\section{FOLRTII MEMORANDUM BOOK, 1758.}

OLD Cibber's brother, at Winchester College, in Doctor Young's time, was reckoned ingenions as well as loose, his conduct was so immoral that even Colley used to reprove him.-IIis varying at school,

Quam pulchrum est digito monstrari, et dicier hic est ;

Hie mihi, quam mœste vox sonat ille fuit.

He was a vile rake afterwards, and in the greatest distress ; Colley used to reprove him for it. He told Dr. Sim. Burton, on a visit, "that he did not know any sin he had not been guilty of but one, which was avarice; and if the doctor would give him a guinea, he would do his utmost to be guilty of that too."-Di. Young.

As to please in the world, people don't mind what is right, but what is in fashion; so in Gardening, to please in laying out a friend's grouuds, one must not mind what the place requires, so much as liow to adapt the parts, as well as one can, to what he wants.-., Spence.

There was a club held at the King's ITead in Pall Mall, that arrogantly called itself " The World." Lord Stanhope, then (now Lord (liesterfield) Lord Herbert, \&c. \&e. were members. Epigrams were proposed to be written on 
the glasses, by each member after dinner; once when Dr. Young was invited thither, the doctor would have declined writing, because he had no diamond: Lord Stanhope lent him his, and he wrote immediately-

"Accept a miracle, instead of wit;

See two dull lines, with Stanhope's pencil writ."

$$
\text { Dr. Young. }
$$

The title of my poem (Night Thoughts) not affected; for I never compose but at night, except sometimes when I am on horsebaek.-Di. Foung.

"Quid dices de me quando reverteris in patriam tuam?" said Dr. King to a Swede who had resided in Oxford some time for his studies (with an air of anxious and proud expeetation)- "Dicam, Insignissime Vir,-te esse magnum Grammaticum," said the Swede. The doctor turned away quite mortified and chop-fallen.-Mr. H(oolee, Jun.

END OF SUPPLEMENTAL ANECDOTES. 


\section{ADDITIONAL NOTES.}

\section{P. T, Southcote.}

TIIIS aneclote is related in different terms in Ruffhead's 1 life of 'ope, p. 509.

P. 18, Wycherley, sc.-In a letter to Mr. Blount, dated 21 Jamuary, 1718, lope lints at this aneedote, and makes the following addition:

"'The evening before he expired, he ealled his young wife to his bed-side, and earnestly entreated her not to deny him one request, the last lie should make. Upon her assuranees of consenting to it, he told her:- My dear, it is only this, that you will never marry an old man again :' I cannot help remarking, that siekness, whieh often destroys both wit and wisdom, yet seldom has power to remove that talent which we eall humour. Mr. Wyeherley showed his, even in this last compliment, though I think his request a little hard, for why should he bar her from doubling her jointure on the same easy terms."

P. 34, Dr. Clarke.-In a letter of Ramsay's to the younger Racine, is the following very curious passage, which has been alrealy pointed out by Dr. Joseph Warton, Essay on Pope, vol. ii. p. 180.

"M. Le Cheralier Newton, grand géométre et nullement métaphysicien, étoit persuadé de la vérité de la religion: mais il voulnt rafher sur d'anciennes erreurs Orientales, et renouvella l'Arianisme par l'organe de son fameux disciple et interprête, M. Clarke; qui m’avoua quelque tems avant que de mourir, après plusieurs conférences que j'arois eues avec lui, combien il se repentoient d'avoir fait imprimer son ouvrage. Je fus témoin, il y a douze ans, à Londres, des derniers sentimens de ce modeste et vertueux Docteur."CEuvres de L. Racine. tom. i. p. 233. 
P. 114-15, Garth, \&c.-Of Garth, Pope says in his letters : "The best natured of men, Sir Samuel Garth, has left me in the truest concern for his loss. His death was very heroical, and yet unaffected enough to have made a saint or philosopher famous. But ill tongues, and worse hearts, have branded his last moments, as wrongfully as they did his life with irreligion. You must have heard many tales upon this subject : but if ever there was a good Christian, without knowing himself to be so, it was Dr. Garth."-It was finely said of Garth, that no physician knew his art more, nor his trade less.

P. 139, Parnell, \&c.-Ruffhead, on the authority of Warburton, has given a different account of the cause which led to Parnell's intemperance:

"When Parnell had been introduced by Swift to Lord Treasurer Oxford, and had been established in his favour by the assistance of Pope, he soon began to entertain ambitious views. The walk he chose to shine in was popular preaching : he had talents for it, and began to be distinguished in the mob places of Southwark and London, when the queen's sudden death destroyed all his prospects, and at a juncture when famed preaching was the readiest road to preferment. This fatal stroke broke his spirits; he took to drinking, became a sot, and soon finished his course."

P. 258, Rowe.-MIrs. Oldfield used to say: "The best school she had ever known, was only hearing Rowe read her part in his tragedies." 


\section{APPENDIX.}

\section{LETTERS CHIEFLY OF EMINENT}

PERSONS TO MR. SPENCE,

ETC. 



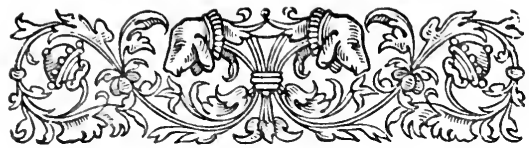

\section{APPENDIX.}

LETTERS TO MR. SPENCE, ETC.

No. I.

MR. POPE TO MR. SPENCE.*

DEAR SIR

Tuitenham, Oct. 7 th.

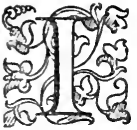

IIEARTILY thank you for the very kind Letter, and kind Entertainment, whieh gave me a greater pleasure than I almost ever reeeived in any Entertainment; it was so easy, and so warm an one. I left you all with regrett: pray tell Mr. Hay so, and MIr. Ayscough : I conclude Mr. Murray is gone from you-You'll oblige me in sending those Letters, not that I'll take from you any one testimony of my Regard and Love for you, $w^{\text {ch }}$ you think worth the keeping. You shall have a fair ace ${ }^{t}$ of 'em when you come this way: but the sooner I have them the better, by a safe hand.-My health is pretty well restored, I know is the news you'l best like from this place; and the rest is only to repeat

- This is the only letter of Pope among Mr. Spence's Papers, and it will account for the absence of others. $\Lambda$ fter Pope had found his Jetters a marketable commodity, he got all he could back from his correspondents. - The date of the year is omitted, as is almost always the case in Pope's letters; but I should judge this letter to have been written about the year 1735.-Editor. 
that sincere truth you have heard so often, and shall hear while I live, that I am most affectionately

Yours.

Mr. Spence.

A. POPE.

No. II.

FROM MIR. CHRISTOPHER PITT.

'THO' eternally plagued with composing sermons for my1 self, and differences for my Parishioners, and with Parish treats, and choosing Church-wardens; I have stole a minute, you see, to thank you for your kind letter; Methinks 'tis a long time Jo, since we have heard from one another before; I don't know which of the two is in fault, but I hope we shall both mend for the future.-If you are in earnest when you commend my translation, $I$ have reason to be proud indeed !-And I must own that it is something the better for your perusal and advice; had you been so kind as to have read and remarked on the whole Translation, I should have been better satisfied with it. But as it is I have met with encouragement (I don't mean money) for this slight performance. I am glad to find, by another part of your letter, that you have made so great a progress in Astronomy of late, and I'll assure you — Odso! I am afraid I shall want room for the following Prologue for the Blandford Strollers, which I writ about a month ago.

Genteels! of old the Prologue led the way, To lead, defend, and usher in the play;

As saucy footmen run before the coach, And thunder at the door my Lord's approach; But though they speak your Entertainment near, Most Prologues speed like other bills of fare;

Seldom the languid stomach they excite, And oftner cloy, than whet the appetite.

As for our play-it is not worth our cares, Our Prologue craves your mercy for the play'rs; 
That is-Your money; for by Ileav'n I swear, White gloves and Ilouse rent are excessive dear.

Since here are none but friends, - the truth to own;

Thongh in a cotch our eompany eame down, Yet, I most shrewdly fear, they must depart Ev'n in their old original a eart.*

With pride inverted and fantastie pow'r, We strut the fancied sovereigns of an hour. While duns our Emperors and IIeroes fear And Cleomenes starves in earnest here. The mightiest Kings and Queens we keep in pay, Support their pomp on eighteenpenee a day. Our Cyrus has been fore'd to pawn his eoat, And all our Cassars eant eommand a groat. Our Scipios Anthonys and Pompeys break, And Cleopatra shifts but onee a week.

'To aggravate the ease, we have not one Of all the new refinements of the Town. No moving statue, no lewd harlequins; No pasteboard play'rs, no Aetors in maehines;

No rosin to make lightning; ('twould exhaust us

To buy a Devil and a Doctor Faustus ;)

No millers, Windmills, Dragons, Conjurers, To exercise your eyes, and spare your ears. No paper seas, no thunder from the skies; No witehes to deseend, no stage to rise; Searee one for us the Aetors.-We ean set Nothing before you but mere sense and wit; A bare downright old fashion'd English feast, Such as a Briton only ean digest; Such as your homely fathers used to love, Who only eame to hear and to improve. Humbly content and pleased with what was drest When Shakspeare, Lee, and Dryden ranged the feast.

\section{I am Dear Jo. Yours very truly}

CII. PITT.

- Which proved true, for they went away in one yesterday. 
No. III.

\section{FROM MR. R. DOWNES.*}

\section{DEAR JOS :}

L. Derry Jan. 24. $172 \%$.

YOURS of the 17 of Decr: I have now before me, which 1 had been sooner answer'd, had I returned sooner from a Tour I have been lately making among my Acquaintance in this part of the World. I rece ${ }^{\mathrm{d}}$ : it the Day before I set out upon this Expedition, but as I intended that should be very short, I ventur'd to defer writing to you till my return. The sollicitations of my Friends and an Inelination to rambling, has kept me out much longer, than I proposed, and is the true reason of my dear Jos:'s not hearing from me. Your easiness under the Disappointments, with my Schemes of sending money to you have met with is no small Addition to the Obligation I have long been under to you: It is with great Grief I must tell you, that your last Disappointment was owing to the Death of the dear [friend] to whom I directed you to apply. He died about the beginning of Decr: of a [cruel] consumptive Disorder, which had oppress'd him for some Months, and incapacitated him for Business of any kind. The Nature of his distemper laid us under some apprehensions of Danger, but never lead us to think that hewas so near his end. Since tlis unhappy accident I have communicated that Affair to my Brother 'Tom, at whose return to Oxŏn, which will be some time in the Summer, I will certainly send you what money is due for Interest, and (if I can possibly,) the Principal but however I would not have you depend upon the latter because it is more than I can absolutely engage to perform, unless your Occasions should call for it, and then I will infallibly have it paid however I eome by it.

* My old friend, Bob Downes, is at present Dean of Derry in Ireland.-My other great friend, Mr. Smyth, (who paid me that unlucky visit at Lyons, when I was with Lord Middlesex,) is perhaps not unlikely to be Bishop't in the same country. Mr. Spence to his Mother, Nov. 4, 1741. 
The Ace ${ }^{t}$ you give of the State of Religion in Oxŏn, is really a melancholy one. Stevens of Trinity, whose Person I do not know, I remember to have heard mention'd as an ingenious Man, and particularly noted for his Knowledge in the Mathematicks. I have often thought, that the stuly of the Mathematicks however usefull and neeessary in Natural lnowledge, yet when enter'd too deeply into, is of no very great Service to Religion. For tho', when moderately pursued, it may inleed be of use in forming a clear llead and distinet Juigement, yet there is this evil attends a too close

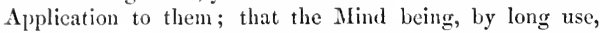
accustomed to close with none but demonstrative Truths, does not easily rest in anything which fills short of Demonstration. So that when the Truth of reveal'd Religion come under its scrutiny, however clear they may be from their own proper Arguments, yet the Mind is dissatisfied, and rejects them for want of that kind of Evidence which it has been accustomed to, but which they neither pretend to, nor indeed are capable of. Whether this be the true reason of the thing I cannot say, but if I an singular in my Opinion I have this to say for myself, that experience has of late been pretty much of my side as to the matter of Fact, that MIen of Mathematical IIeads, and your great Masters of Demonstration, have been among the foremost, who have run into the Principles of Deism. The other Person you speak of, Caber, I do not know; Young Dodwell I have had some Acquaintanee with, and am the more sorry to hear that he is among the infeeted; you do not say whether he was expell'd or not. I should be glad to know in your next what were the real or pretended Grounds of those Persons, whom you mention, being against the Programma. Because it is possible they may be able to give better Reasons for their dissenting, than the ill-natur'd World will be ready to give for them. Tom joins with me in humble Service to you, Coxed, Coker, and all Friends. He seems to think Mr. Coker's Memory wants a jog to put him in Mind of writing to him according to promise, which he desires you to do. My hearty Service to honest Jack Briscoe, and wherever else you think 
it will be acceptable. I have reserv'd to the last what was uppermost in my Thoughts, I mean to congratulate you on a Paragraph I lately rec ${ }^{\mathrm{d}}$ : in a Letter from Merton."Your Friend Spence has read his first Leeture which was universally admir'd for its Learning and Elegance-Even Hutchinson of Hart-Hall said.-it was well enough."-If you would but eram it into a sheet of Paper, and send it hither directed to me, you would make me more than ever, Mr. Professor's

most oblig'd and $A$ frecte P. DOWNES.

\section{No. IV.}

\section{FROM DR. EDWARD YOUNG.}

DEAR $\mathrm{s}^{\mathrm{T}}$.

TROMISED my Friend Mr. Tompson* who is now 1 finishing his Subscription in Oxford, all the advantages I could give him ; for $\mathrm{w}^{\text {ch }}$ reason I beg leave to introduce him to so valuable an acquaintance as $\mathrm{Y}^{\text {rs. }} \mathrm{W}^{\text {ch }}$ freedom $\mathrm{I}$ hope You will pardon in

Dear Sir

$\mathrm{Y}^{\mathrm{r}}$ most obedient and faithfull Servt.

A pril the first 1729 .

E. YOUNG.

\section{No. V.}

FROM MR. STEPHEN DUCK.

DEAR $s^{\mathrm{T}}$.

Octotr $29^{\text {th }} \cdot 1735$.

HOPE this will find You much better than I am at pre1 sent, for I have a violent pain in my baek, which makes me incapable of doing anything besides writing and reading; and indeed I have now pretty good employment in that, having begun printing my poems. I hope I have been

* i. e. James Thomson, Author of the Seasons. 
tolerable happy in correeting those places which You kindly remark'd, when here, and have made some other little alterations (which appear'd to me) for the better. I have been at 'Twickenham, but had not the pleasure to see Mr. P'ope, Ife being in London. I hear the pirated Edition of His Works are stop'd; at least I cannot have it in 'Town; And our Scheme at Curls is spoil'cl. Just after I came home from Oxford, I was sat in my Conjurer's Cave, when I was surpriz'd with two Persons, who eame in, and Calling me by Name, ask'd how my subscription went on? As well, said I, as I con'd wish, considering the season of the Year. Immediately one of the person's (who had a more than ordinary ill Aspect) answer'd, that if I did not get a licence, my book would be pirated in a week after 'twas publish'd. I answer'd, that I did not see how even a licence wonld secure a Mian's property now, when Printers and Booksellers, in defiance of all justice and honesty, pirated everything they conld lay hands on; I alded that I had been inform'd Mr. Pope's works which he sold to Gilliver, had not eseap'd this fate. As I mention'd $\mathrm{Yo}_{0} \mathrm{r}$. Friend Mr. Pope; the Gentleman put on a more terrible Countenance, and, with a particular emotion, told me that I " talk'd quite out of my province; " and that I knew nothing of Pope or Gilliver either, and " that Gilliver had no more to do with Mr. Pope's Works, "than he himself, or any other person." IIe then told me, with an air of insolence, that his Name was Curl, and should be very glad to see me in Corent Garden. I beg pardon for troulling You so long about this worthless subject, but when I am writing to You, I think I am talking to a friend, whose good nature will pardon all freedoms. I am

\section{Dear $\mathrm{S}^{\mathrm{r}}$.}

Yor. most oblig'd

most grateful

humble Serv ${ }^{\mathrm{t}}$

S. DUCK.

My Wife desires her humble Service, and I beg mine to Yor $^{r}$. Mother and Sister when you write. 


\section{No. VI. \\ FROM MR. A. SMYTH.*}

$D^{\text {T }}$ Jo:

I ALWAYS thought myself happy in your correspon1 dence, and you are resolv'd every letter you write, to confirm me in that opinion; If I were to chuse a correspondent, I cou'd wish for nothing more, than one who wou'd always please me with the length of his letters, and that cou'd be satisfied with the shortness of mine: you speak the true language of a polite Toper, that gives his friend leave to drink as little as he pleases, provided he will let him drink as much. you are so kind, as to say you'll be contented $\mathrm{w}^{\text {th }}$ a line and a half a quarter, so I shall do my uttermost to "Strain from hard bound brains six lines a year," but as your head is not so costive, I shall expect to find your paper much more plentifully furnish'l, and a great deal oftener: if you think it umreasonable in me to expect a 'Talent from you for my Mite, I shall defend myself by pleading Poverty. I suppose by this time you are no stranger to the affair that happen'd the $30^{\text {th }}$ of January in Suffolk-street, and that it is no longer a secret that Lord Middlesex, $\mathrm{L}^{\mathrm{d}}$ Harcourt, Mr. Strode, and Mrr. Denny were unfortunately of the company. The affair has been grossly misrepresented all over the Town and in most of the publick paper's and if ever you hear it mention'd in Company, in justice to the Gentlemen's characters I hope you will vindicate'em and take it upon my honour that what I write is true; there was no Calf's head expos'il at the window, and afterwards thrown in the fire, no Napkins dipt in Claret to represent blood, nor nothing that cou'd give

* Mr. Spence writes to his Mother from Florence, Oct. 12, 1732. - "I found here a most particular friend of mine from Oxford, Mr. Smyth, son to the late Bishop of Limerick. I don't know whether I ever mentioned his name to $\mathrm{y}^{\prime} \mathrm{m}$; he was the firiend that Bob Downes sent me from Ireland to Uxfurd, and one of the best tempered men in the world." 
any colour to such reports. The meeting (at least with regard to our friends) was intirely accidental, the only reason for it's being on that day was because it was an idle day in the houses of parliament, they had a bonfire 'tis true, but that was not resolv'd upon nor thought of till they were all drunk; and then they were led into it hy having seen another in the street. The only healths they drank to the populace, were the Royal Family, Liberty and Property, and the present Administration, which last not happening to be very popular was the only cause of the Riot, I'll tell you the other particulars when I see you in 'Town, in the mean time I am $\mathrm{Y}^{\mathrm{rs}}$ most affecly.

A. SMYTH.

$\mathrm{MI}^{\mathrm{r}}$. Strode desires his best respects to you. Tuesday.

\section{No. VII. \\ FROM THE SAME.}

$D^{\mathrm{T}}$. Jo:

F I was surpris'd at receiving a letter from you so soon Lafter your former, I'm sure it was very agreeably; tho' I can't say I desire a pleasure of that nature any more, for I hope to receive letters from you so frequently, as to make it f:miliar to me to expect very quick successions of 'em As to the affair you mention I am too well acrquainted $w^{\text {th }}$ it. If I had not had friends concern'd in it, I shou'd not probably have known so much of the matter; I am very much troubled about it, not so much for what was really done, as for the light, that the illnature and love of telling strange news has made the generality of people represent it in. I wrote you some account of it last post; but for fear you shou'd not have receiv'd the letter, I shall write it to you again: the affair in short stands thus. Some friends agreed to dine together last thursday at a Tavern, not because it was the $30^{\text {th }}$ of Jany, 
but because it was an idle day at Westminster; when they were pretty well heated $w^{\text {th }}$ liquor, one of the company happen'd to look out of the window and see a few shavings lighted in the street, this put him in mind of a bonfire, and he immediately propos'd it to the company to have one before their door. As the proposal had something of jollity in it, and they were well warm'd $w^{\text {th }}$ Champagne, they all readily agreed to it; so there were some fagots order'd directly. They were no sooner lighted, but a great mob was gather'd about 'em, among whom there appear'd some gentlemen animating'em and giving'em money to insult the gentlemen in the Tavern. When the mob was rais'd under the window, the company order'd 'em some beer; and appear'd at the windows $\mathrm{w}^{\text {th }}$ their glasses in their hands, drinking to 'em several healths as the King and Royal Family, Liberty and Property, \&e. after every one of $w^{\text {ch }}$ there was a general shout of the people. At last, one of 'em unlnekily propos'd the present administration, this rais'd a few faint elaps but a general hiss; some of the eompany were sober enongh to know that the anger of a mob wou'd not end there, and so they immerliately shut down their windows, $w^{\text {ch }}$ was no sooner done but the mob furiously attack'd the house $w^{\text {th }}$ stones and brickbats, broke all the windows to pieces and wou'd probably have broke open the house if the Guards from $\mathbf{s}^{t}$. James's had not come to the relief of the gentlemen. As for a Calf's head being expos'd at the window, and their having drank damnation to the race of the Stuarts, $w^{\text {th }}$ other idle reports of the like nature, there is not a syllable of truth in 'em. When the affair was first told the King he was in a very great passion, not knowing when a mob was once risen, where their fury wou'd end; but since the matter has been fairly represented to him, and all things are now quiet, he looks upon it, as every other person of sense does, as a drunken froliek. The Company were $L^{d}$ Midalesex, Ld. Hareourt, Ld . Boyne, $\mathrm{L}^{\mathrm{d}} \mathrm{J}^{\mathrm{n}}$ Nurray, $\mathrm{I}^{\mathrm{r}}$. Strode, $\mathrm{M}^{\mathrm{r}}$. Sherly, $\mathrm{S}^{\mathrm{r}}$. James Gray, and Mr. Denny ; this is the whole number tho' several others are nam'd. The Charaeters and principles of these gentlemen secure 'em sufficiently (among those that know 'em) from 
any suspicion of a premeditated design to insult the memory of $K$. Charles, but still there are a great number of people to whom they won't have an opportunity of clearing themselves. The other circumstances of this unlucky affair I shall tell you when I sce you. this is enough to make you less concern'd about it, and to enable you to answer the calumnies of ill-natur'd people. you may depend upon my word for the truth of it. I am sorry you are detain'd longer at Oxford; I hope you will make amends by the freqnency of your letters for the loss I have of your eonversation.

\section{I am my dear Spence's}

Sincere friend and $\mathrm{Ser}^{\mathrm{t}}$.

London Bond Street. Feb. $6 i h$.

A. SNYTH.

No. VIII.

\section{FROM LORD MIDDLESEX.}

DEAR SPANCO

Whilehall, Feb. $y^{\mathrm{e}} 9^{\text {th }}, 1735$.

DON'T in the least doubt but long before this time, the noise of the riot on the 30 of Jan: has reach'd you at Oxford, and tho' there has been as many lies and false reports rais'd upon the oceasion in this good City, as any reasonable man eould expect, yet I faney even those may be improv'd or enereas'd before they come to you. Now that you may be able to defend your Friends (as I don't in the least doubt you have an inclination to do) I'll send you the matter of faet literally and trnly as it happen'd, upon my honour. Eight of us happen'd to meet together at dinner the $30^{\text {th }}$ of January it might have been the $10^{\text {th }}$ of June or any other day in the year, but the mixture of Company has convinc'd most reasonable people by this time that it was not a design'd or premeditated affair. We met, then as I told you before, by chance upon this day, and after dinner having drank very plentifully, especially some of the company, some 
of us going to the window unluckily saw a little nasty fire made by some Boys in the street, of straw I think it was, and immediately ery'd out, dam it, why should not we have a Bonfire as well as any body else. Up comes the Drawer, ' dam you you Raseal get us a Bonfire.' Upon which the imprudent puppy runs down, and without making any difficulty, (which he might have done by a thousand excuses, and which if he had in all probability some of us would have come more to our senses,) sends for the faggots and in an instant Behold a large fire blazing before the door. Upon which some of us wiser, or rather soberer, than the rest, bethinking themselves then for the first time what day it was, and fearing the consequences a Bonfire on that day might have, propos'd drinking Loyall and popular Healths to the Mob (out of the Window) which by this time was very great, in order to eonvince them we did not intend it as a ridicule upon the day. The Healths that were drank out of the Window were these and these only. 'The King Queen and Royal Family, the Protestant succession, Liberty and Property, the present Administration. Upon which the first stone was flung, and then began our siege; which for the time it lasted was at least as furions as that of Philipsbourg. it was more than an hour before we got any assistance, the more sober part of us during this had a fine time of it; fighting, to prevent fighting; in danger of being knock'd o' the head by the stones that came in at the windows; in danger of being run thro' by our mad Friends, who sword in hand swore they would go out, tho' they first made their way thro' us. At length the Justice, attended with a strong Body of Guards, came and disper's'd the populace. 'The Person who first stir'd up the mob is known, he first gave 'em mony and then harangu't them in a most violent manner, I don't know if he did not fling the first stone himself. He is an Irishman and a Priest, belonging to Imberti the Tenetian Envoy. this is the whole story from which so many Calves heads, Bloody napkins, and the Lord knows what has been male, it has been the talk of the Town and the Country, and Small beer and Bread and Cheese to my 
friends the Garretters in Grub street for these few days past. I, as well as all your friends, hope to see you soon in Town. After so much prose I ean't help ending with a few Verses.

O had I liv'd in merry Charles's days,

When dull the wise were eall'd, and Wit had praise,

When deepest Politicks could never pass

For ought, but surer tokens of an Ass.

When not the Frolicks of one drunken night

Conld touch your Ilonour, make your Fame less bright 'Tho' mob-form'd Scandal rag'd, and Papal spight.

\section{MIDDLESEX.}

\section{No. IX.}

The three following Letters of Mr. Spence to his Mother, are inserted, on aecount of the amusing particulars contained in them.

Eaitor.

\section{TO MIRS. SPENCE.}

DEAR MOTHER

Turin, Dec ${ }^{\mathrm{r}} 2,1739$.

COON after I came to this plaee, as I was walking one $D$ Evening under the Porticos of the Street of the Po, I saw an Inscription over a great Gate; which, as I am a very curious 'Traveller, you may be sure I did not miss reading. I found by it, that the House belong'd to a sett of Strollers, and that the Inscription was a Bill of the Play they were to act that Evening. You may imagine how surpris'd I was to find it eonceiv'd in the following words: "Here under the Portieo's of the Charitable Hospital for such as have the Venereal Disease, will be represented this Evening, The Damned Soul: w $^{\text {th }}$ proper Decorations." As this seem'd to be one of the greatest Curiosities I eou'd possibly meet with in my Travels, I immediately paid my three-penee; was shew'd in with great eivility; and took my seat among a number of people, who seem'd to expect the Tragedy of the Night with great Seriousness. 
At length the Curtain drew up; and discover'd the Damn'd Soul, all alone, with a melancholy Aspect. She was (for what reason I dont know) drest like a fine Lady ; in a gown of Flame-colour'd Satin. She held a white Handkerchief in her hand, which she apply'd often to her eyes; and in this attitude, with a Lamentable Voice, began a Prayer (to the Holy and ever Blessed Trinity) to enable her to speak her part well : afterwards she address'd herself to all the good Christians in the Room; beg'd them to attend carefully to what she had to say: and heartily wish'd they wou'd be the better for it: She then gave an account of her Life; and, by her own confession, appear'd to have been a very naughty woman in her time.

This was the First Scene. At the Second, a back curtain was drawn; and gave us a sight of our Saviour and the Blessed Virgin : amidst the Clouds. The poor Soul address'd herself to our Saviour first, who rattled her ex treamly: and was indeed all the while very severe. All she desired was to be sent to Purgatory, instead of going to Hell : and she at last beg'd very hard to be sent into the Fire of the former, for as many years as there are drops of water in the Sea. As no favour was shown her on that side, she turn'd to the Virgin and beg'd her to intercede for her. The Virgin was a very decent woman : and answer'd her gravely, but steadily; "That she had anger'd her Son so much, that she cou'd do nothing for her ;" and on this, they both went away together.

The Third Scene consisted of three little Angels, and the Dann'd Soul. She had no better luck w ${ }^{\text {th }}$ them : nor with St. John the Baptist, and all the Saints in the Fourth: so, in the Fifth, she was left to two Devils; seemingly to do what they wou'd with her. One of these Devils was very ill-natur'd and fierce to her ; the other, was of the droll kind; and for a Devil, I can't say but what he was good-natur'd enough : tho' he delighted in vexing the poor Lady rather too much.

In the Sixth Scene, matters began to mend a little. St. John the Baptist (who had been with our Saviour, I believe 
behind the Scenes) told her, if she wou'd continue her Entreaties, there was yet some Hope for her. She on this again besought our Saviour and the Virgin to have eompassion on her: the Virgin was melted with her Tears, and desir'd her Son to have pity on her; on which it was granted, that she shou'd go into the Fire, only for sixteen or seventeen hundred Thousand years; and she was very thankful for the mildness of the Sentence.

The Seventh (and last) Scene, was a Contest between the two Infernal Devils above-mentioned, and her Guardian Angel. They came in again; one grinning, and the other open-mouth'd to devour her. 'The Angel told them, that they shou'd get about their business. He, with some difficulty, at last drove them off the Stage; and handed off the good Lady; in assuring her that all $\mathrm{w}^{\mathrm{d}}$ be very well, after some hundreds of thousands of years, with her.

All this while, in spite of the excellenee of the Actors, the greatest part of the Entertainment to me was the countenances of the people in the Pitt and Boxes. When the Devils were like to carry her off, every body was in the utmost consternation; and when St. John spoke so obligingly to her, they were ready to ery out for Joy. When the Virgin appear'd on the Stage, every body lookd respeetfull; and on several words spoke by the Aetors, they pull'd off their Hats, and cross'd themselves. What ean you think of a People, where their very Farces are Religious, and where they are so Religiously receiv'd? May you be the better for reading of it, as I was for seeing it !

There was but one thing that offended me. All the Aetors, except the Devils, were Women: and the person who represented the most venerable character in the whole Play, just after the Representation, came into the Pitt; and fell a kissing a Barber of her Aequaintanee, before she had chang'd her Dress. She did me the honour to speak to me too; but I wou'd have nothing to say to her.

It was from sueh a Play as this (calld Adam and Eve) that Milton, when he was in Italy, is said to have taken the First Hint for his Divine Poem of Paradise Lost. What 
Small Beginnings are there sometimes to the Greatest Things! I am ever (with all Services to all Friends)

\section{Your Dutiful and Affection ${ }^{\text {te }}$.}

J. SPENCE.

\section{TO MIRS. SPENCE.}

DEAR MOTHER

Turin, Augt : 17, 1740.

I

HAVE been a little journey out of Town, since I wrote my last. My Lord Lincoln took a ride out with the Prince of Carignan, to a Nobleman's about 24 miles off, to be at a Ball: the next day I heard he had sprain't his foot, and was in a great deal of pain. So I took a Chaise immediately, and earried a very famons old Surgeon $w^{\text {th }}$ me, recommended by our Minister here; to see whether there was any greater harm than was imagin'd: and $I$ hope $m y L^{d}$ is in a way of being well soon.

My old Surgeon I found to be the oddest Figure, and one of the oddest men, that ever I met with, in my life. He is a Mountaineer; born amidst the Alps; and as learned* as the people generally are among wild mountains. IIe is a short man, fat, and elumsy: with a great pair of Dutch Trowsers to his posteriors; and with a face, that does not at all yield, for breadth, or swarthiness, to the place above mention'd. His face was overrun with beard; for he said he was obliged to go to Mass, and so had not time to be shav'd. In his face, or his upper breech, whichever you please to call it, were a pair of little merry eyes; deep in his head; but yet with a droll gay air in them: and the two little caves that go down to them are wrinkled all the way up to his forehead and his temple. Whenerer he laughs, (whieh is very often,) all these wrinkles are in motion to-

* "Tis not Learning that does any gond. A man may read Post Borks for ever, withont knowing a Rearl. One must have travel'd 'em, to know anything of them. I practise : and let the others read, in Gods name," says M : Claude. 
gether; and make one of the most diverting sights that ean be imagin'd. When we were a little seated together, and jolted into our proper places by the Chaise; "Is it a long time, MIaster Clande, (says I) that you have been in this sort of Business?" Yes, says he, I lave been in it for several Generations. Upon this I thought myself with the Travelling Jew; and bless'd Ieaven for bringing me acquainted with a man, that I had so long wish'd to meet with. "For several Generations, Master Claude? I don't understand you." Why, Sir, says he, our Family have always been Barber-Surgeons; from Father to Son, without any Interruption for these 28 Generations; my Son, who is a promising Youth and is scaree Fifty yet, is the $29^{\text {th }}$. I am but Seventy five; and 1 have had this plagny Gout these twelve years. Will you be so good as to let me replace my foot again ; for that last jolt has quite put me out of order. "And how old was your Father, Master Claude, when he dy'd ?" $\mathrm{Ah}$, poor man, he died at a Hundred and Three: but 'twas by a fall from his horse, in going to visit a Patient. He was hurried out of the world: Rest his soul :-"At this rate, the First Surgeon in your Family, might have been Surgeon to Noah, and the good people in the Ark."-This set all his wrinkles in motion. Oh no, (says he, ) we are not of so great Antiquity as that comes to: at least, our Accounts don't reach up so fir-" Have you a Ifistory then of the 27 Surgeons, your Predecessors?"-ILave I, says he! yes that I have; and I wou'd rather lose my legs, than lose it. But that does not go so far as I cou'd wish; the furthest thing back, of a remarkable thing, that $I$ find in it, is that the Fifth Surgeon of our Family shav'd Hannibal, the night he lay at Laneburg, in his Passage over the Alps: I wish he hat cut his throat; for he did a deal of misehief here at Turin."And did he shave ever" a one of his Elephants, Master Claude?"-Not that I know of, says he ; but our Day-Book says, that this same Hannibal had to do with the Devil; that he put life into Castles; and made the Castles walk over the Mountains with him against the Romans : and he says, in a note on the side, that he heard afterwards, that these Castles 
fought like mad things; and that any one of them that had not kill'd his hundred of Romans, was very little regarded in the Army. He then took out a Prayer Book; and pray'd aloud, as he had done at every Cross, or old Statue, we had pass'd by the road side.-_"I don't see a Virgin Mary; why are you praying, Master Claude?"-I'm saying a Devotion, to pray poor Hannibal's Soul out of Purgatory, (says he ;) he was a great 'Thief and Murtherer; and may very probably be there still; but he paid my Ancestors well; and so I am bound to pray for him. You see that House there! twas built by a Savoyard: he put his Collar bone out, and I set it. Lord have mercy upon poor Hannibal! Will you have another pinch of Snuff? this Snuff box was giv'n me by the Marechal de Crequi-“" You have travel'd then ?"-Ay, Sr, no body is regarded in our Country, unless they have roll'd over the world. I liv'd 20 year in France and Germany; I was Barber-Surgeon to the Marechal; and was with him when he receiv'd his death's wound._- And is it true that the Ball that kill'd him, was directed to the Marechal de Crequi?"-No, Sr, says he, that I can assure you it was not; for 'twas these fingers took it out of his body.-Just as he said this, we came to our Journey's end; as I am, at the end of my Letter.

\section{No. XI.}

\section{TO MRS. SPENCE. (3.)}

\section{DEAR MOTHER}

Turin, Augt: 25, 1740.

T F the History of Florio was too Melancholy for you (as I 1 fear it was) I am now going to give you an account of some people that may be too mysterious for you: such as some persons will scarce believe ever were, or ever will be, in the world: however one of them, I have very lately met with; and I must give you an account of him whilst tis fresh in my Memory.

Have you ever heard of the people, call'd Adepts? They 
are a sett of Philosophers, superiour to whatever appear'd ansong the Greeks and liomans. 'The three great points they drive at, is to be free from Poverty, Distempers, and Death : and if you will believe them, they have found out one Seeret that is capable of freeing them from all three? There are never more than twelve of these men in the whole world at a time; and we have the happiness of having one of the twelve at this time at 'Turin. I am very well acquainted with him ; and have often talkd with him of their Secrets, as far as he is allow'd to talk to a common mortal of them.

His name is Andrey: a Frenchman; of a Genteel Air; but with a certain Gravity in his face, that I never saw in any Frenchman before. 'The first time I was in company with him, as I found he had been a great Traveller, I ask'd him whether he had ever been in England, and how he lik'd the Country? He said that he had, and that he lik'd it more than any Country he had ever been in. The last time I was in England, added he, there were Eleven Philosophers there. I told him I hop'd there might be more than Eleven in England. He smiled a little and said; $\mathrm{S}^{\mathrm{r}}, \mathrm{I}$ dont talk of common Philosophers; I talk of Adepts; and of them I saw in England, what I never saw anywhere else; there were Eleven at Table; I made the Twelfth: and when we began to compare our Ages all together, they made somewhat upward of Four 'Thousand Years. I wonder'd to hear a grave man talk so strangely, and askd him, as seriously as I cou'd, how old he might be himself. He said, that he was not quite 200 ; but that he was one of the youngest at the Table. He said that the Seeret of carrying on their lives as long as they pleasd was known to all of them; and that some of them perhaps might remove out of this world, but that he did not think any one of them would dye: for if they did not like this Globe, they had nothing to do but to go into another, whenever they pleased. Ilow soon that might be, he did not know, but $S^{t}$ John and the Travelling Jew, he said, had staid in it above 17 liundred years; and some of his Friends perbaps might stay as long. He said the Great Elixir, of $w^{\text {ch }}$ he had some in his pocket, made him look no older than Forty; that 
he was afraid of no distemper, for that would cure him immediately; nor of Want, because t'wou'd make him as much Gold as he pleas'd. He said many other things as strange, and as surprizing, as what I have told you.

I was talking of lim and his Gold-making to our Minister here: who, upon this told me a very odd story, which he had from Marechal Rhebender, General of the King of Sardinia's Forces at present. The General (who comes from those parts) says, that when Gustavus Adolphus was going to make War with the Emperour, he found himself at a loss for money sufficient for so great an Undertaking. He was very melancholy upon it, and every thing was at a stand: when one morning a very old man came to his Conrt, and told the Gentleman of the Bedchamber in Waiting, that he wanted to speak to the King. The Gentleman desired his name; he refused to tell it; but said he must speak to the King, and that it was on Business of the utmost importance to his Majesty's Affairs. Gustavus, who was incapable of fear, order'd him to be admitted. When they were alone, the Old Man told him, that he knew what straits he was in for money; and that he was come to furnish him with as much as he shou'd want. He then desird him to send for a Crucible full of Mercury; he took out a white Powder, and put in only $a b^{t}$ the quantity of a pinch of snuff. He then desir'd him to set by the Crucible till the next morning; gave him a large bundle of the White powder: and departed. When Gustavus call'd for the Crucible, the next morning, 'twas all full of one solid piece of Golıl. He coin'd this into Ducats; and on the Coin, in memory of the Fact, was struck the Chymical Marks for Mereury and Sulphur. Rhebender had several of them thus markt, and gave one of them to our Minister who told me the story. 


\section{No. XII.}

\section{FRONI IIORACE WALPOLE.}

SIR

Flurence Feb $21.174 \mathrm{t} \mathrm{N.S.}$

VOT having Time last Post, I begill Mr Mann to thank 1 you for the obliging Paragraph for me in your Letter to llim. But as I desire a nearer correspondence with you than by third hands, I assure you in my own proper person, that I shall have great pleasure on our meeting in England to renew an Aequaintance which I began with so much pleasure in Italy. I will not reckon you among my modern Friends, but in the first article of Virtû : you have given me so many new Lights into a Science that I love so much, that I shall always be proud to own you as my master in the Antique, and will never let any thing break in upon my Reverence for you, but a warmth and freedom that will flow from my Friendship, and which will not be contained within the circle of a severe Awe.

As I shall always be attentive to give you any satisfaction that lies in my power, I take the first opportunity of sending you two little Poems, both by a Ifand that I know you esteem the most : if you have not seen them, you will thank me for lines of Mr. Pope; if you have, why I did not know it.*

I dont know whether Lord Lineoln has receiv'd any orders to return home: I had a letter from one of my Brothers last post, to tell me from Sir Robert that He wou'd have me leave Italy as soon as possible, least I shou'd be shut up unawares by the arrival of the Spanish Troops; and that I might pass some time in France if I had a mind. I own I don't conceive how it is possible these Troops shou'd arrive without its being known some time before. And as to the Great Duke's Dominions, oue ean alway be out of them in ten hours or less. If Lord Lincoln has not received the same orders, I shall * These were Pope's Verses on his Grotto, and Epitaph on Himself. 
beleive what I now think, that I am wanted for some other Reason. I beg my Kind Love to Lord Lincoln, and that MIr. Spence will believe me

His sincere Humble Servt.

HOR. WALPOLE.

No. XIII.

\section{FROM L ${ }^{D}$ ORFORD, TO COL: CHURCIILL.}

\section{DEAR CHARLES}

Fro' Houghton; June 24, 1743.

HAVE now wrote to Capt ${ }^{\mathrm{n}}$ Jackson, to give $L^{d}$ Tyraw ley a Ticket, as you desired; and am glad to oblige him with it. This place affords no News ; no subjects of Amusement, or Entertainment, to fine men. Men of Wit and Pleasure about town understand not the language, nor taste the pleasures, of the inanimate World. My Flatterers here are all Mutes. The Oaks, the Beeches, the Chesnuts seem to contend which shall best please the Lord of the Manour. They cannot deceive; they will not lye. I, in sincerity, admire them; and have as many beauties about me as fill up all my hours of dangling, and no disgrace attends me from 67 years of age. Within doors, we come a little nearer to real Life ; and admire, upon the almost-speaking Canvas, all the Airs and Graces which the proudest of the Town Ladies can boast. IVith these I am satisfied; because they gratify me with all I wish and all I want; and expect nothing in return which I cannot give. If these, Dear Charles, are any temptations; I heartily invite you to come and partake of them. Shifting the Scene has sometimes its recommendation; and from Country Fare you may, possibly, return with a better appetite to the more delicate entertainments of a refined life. Since I wrote what is above, we have been surpris'd with the good News from abroad. Too 
much cannot be said upon it; for it is truly matter of infinite Joy, because of infinite consequence. I am truly,

Dear Charles,

Yours most affectionately,

ORFORD.

\section{No. XIV. \\ FROM MR. W. CARR.}

$R^{d} V^{d}: s^{r}$.

A $S$ you lay me under no restriction $w^{\text {th }}$. respect to time; A I waited for the most convenient opportunity of informing my self of the particular circumstances that attended the Drowning and Revival of the Man at $S^{t}$ : Neots. It was in the Year 1741 that the Accident happen'd to one John Saunders, a Taylor in that Town, at that time abt. 19 Years of Age: who, in washing himself, slipt into a hole above 12 feet deep; where he ascended and descended three several times before he cou'd be laid hold on, and remain'd each time for above a minute under water, when at length he was taken out dead to all appearance. He was carry'd from the River upon mens shoulders $w^{\text {th }}$. his Head inclin'd, and then laid over Chairs in the sane position; but notwithstanding voided no water, tho' swell'd as big as a Porpoise. It was propos'd by some of the Faculty then present to bleed him; but this was strongly objected to by $\mathrm{D}^{\mathrm{r}}$. Quinton, who instead thereof preseribd a Pipe of Tobacco; $\mathrm{w}^{\mathrm{ch}}$. being blown up that part that generally follows for its share, immediately produc'd a violent vomiting; during $\mathrm{w}^{\mathrm{ch}}$ the Body being continually rub'd $w^{\text {th}}$. warm cloths, there soon appear'd such Signs of Life as encourag'd them to proceed in the aforemention'd application, $w^{\text {ch }}$. by degrees produc'd Sense and Motion. He lay for above a fortnight in a very weak condition, but by the use of Cordials and other Restoratives, soon became worth a hundred drown'd men, and 
is now living at Bonhurst in Bedford ${ }^{\text {sr }}$. When come to himself, he was examin'd, but $\mathrm{c}^{\mathrm{d}}$ : give no account of the least Sensation of either Pleasure or Pain, from the time he went under water to the time he recover'd his Speech, when he found himself very sick; the Interval of $w^{c h}$. was $a b^{t} .12$ Hours. The Person who gave me this information, is the Landlord of the Cross Keys in S': Neots, who being an Eyewitness of the whole Proceeding, and a man of credit and veracity: you may I bclieve, depend upon this account's being authentick. I shall be extremely glad if it proves in the least satisfactory, or if by this or any thing else, it lay in my power to acknowledge the obligations confer'd on

$$
\text { Rev }{ }^{\mathrm{d}}: \mathrm{S}^{\mathrm{r}} \text { : }
$$

$\mathrm{I}^{\mathrm{r}}:$ most obed $\mathrm{t}^{\mathrm{t}}$. very humb. Servt.

Kimbolton Octob : $17^{\text {th }} \cdot 1745$ WM: CARR.

P : S. His Grace and Family are all very well.

\section{No. XV.}

\section{FROM MR. N. HERBERT.}

\section{DEAR SPENCE}

A $S$ it is post Night $I$ will not delay a moment answerinformation adequate to the pleasure his request has given me, for it is what $I$ have many years wanted, some person or persons equal to the task, to try experiments in order to see how far they might improve the practice of their foreign predecessors upon this subject. I am sorry I can say foreign for speaking in general I may, notwithstanding the repeated incitements in the Newspapers and publishing Pamphlets upon the subject with directions. We frequently hear of persons lost, especially in the swimming and sliding seasons, without the least attempt to recover 'em, I hope this negli- 
gence proceeds from infidelity and not inhumanity; lut to my sulject. In order to incourage the $\mathrm{D}^{\mathrm{r}}$. you nention, I shall refer him to two now living of his own Profession, and both eminent in it. $\mathrm{D}^{\mathrm{r}}$ Mead in his Mechanical Account of Poisons is very earnest in perswasives to this practice and expressive in directions and $D^{r}$ Shaw told me, Ife himself brought a person to life that hal been under water near 3 Ilours, by only blowing Tobaceo into his Nostrils from an inverted pipe. What first led me to try experiments upon this snbject was reading in Chambers's Dict: a Quotation from Peelin. de Aer et Aliment: def. c. 10. Wherein He mentions a Gardener who was saved after being 16 Hours under Water and that the Queen of France settled a Pension upon him afterwards for Life, and adils he was then living when he wrote his Book, I forgot to tell you I know a Colonel now in the Army Who told me he was recovered himself by this method when he was drown'd as he was swimming when abroad.- - I have not had the opportunity of trying the experiment upon human bodies above 5 times and all of them in this Town, where it is almost impossible to put it in practice without molestation from the ignorant populace. A large Pamphlet was publish'd with directions some years ago, but as I cannot readily find it. I do not know for whom 'tis printed. but I have another Book entitled the uncertainty of the signs of Death at the end of which are near 20 pages upon the suljeet of Drowning this book is printed for II. Cooper at the Globe in Pater Noster Row in the year 1746. - To conclude at present I heartily wish $\mathrm{D}^{\mathrm{r}}$ Armstrong success in his experiments and should be as glad to know the result of them, I have some Agents with whom I have left directions near the sea shore bit cannot find They have as yet try'd any experiments

Yours \&c

Feb: 22.

N. HERBER'T. 


\title{
No. XVI. \\ FROM MR. HERBERT.
}

DEAR SPENCE

$$
\text { July } 1^{\text {st }} 1746
$$

Leiston near Saxmundham in Suffolk.

\begin{abstract}
A $S$ You rather discouraged me from writing by ingenuA ously owning You would be slow in answering I have
\end{abstract} deferr'd till now putting pen to paper to enquire after your health in town, or informing you of ours in the country; but I hope to find, by your speedy answer to this, that your opinion is changed upon this head, and that you intend to be a punctual Correspondent to your friend, who is always glad to hear from you. But least your tender eonscience should tell you; it is a crime to say one thing and do another, I beg to remind you from Scripture, how much more commendable that man was, who went, tho' he say'd he would not go, than He, who say'd he would go, and went not, the latter broke his word, which is always detestable, the former was better than his word, which has always been thought to deserve the highest commendation. How this argument may operate upon you, time will shew; and here I shall leave it. to proceed to give you some account of our manner of living here, the Place itself is much pleasanter than I expected, our situation is about two miles from the sea. When I am in the Cupola, where I sit often, I can see the Ships with a naked eye, but have borrow'd a reflecting telescope, to bring them nearer, and behold them more distinetly, yesterday a very large Fleet of Colliers went by. Which some months ago a timorous mind would have magnified into a French Squadron; but thank God those fears are over, and I found no more warmth or emotion in me at this sight, than naturally arose from thinking what fine fires would be made of the Freight in the Frosty weather. And this idea let me tell you, was not difficult to raise, for the weather here is extreamly Cold; at least seems so to my thin carcase; and I believe would to yours, even cover'd with two coats; if you are still as I left you in the Phrase of Persius, trama figure, 
tho' I hope to find you on my return as IIorace phrases it, Epicuri de grege Porcus. I had the other morning an opportunity of belolding another of Agur's wonders, (for the way of a ship in the sea is one) which was the way of a serpent not according to the text, on a Rock, but on a Dunghill. My Coachmin kill'd six of them successively, the sight put me in mind of the l'icture of Apollo killing the Python. So of my Coachman I may say, as says Latly Froth in the Comedy.-I amuse myself sometimes like the Roman Emperor by picking up eockle shells on the sea shore, and had an opportunity of experieneing, the remedy Demosthenes try'd on himself for Stammering, upon my Girl, who was with me, tho' I did not let her know what I was at, for I had nothing to do but talk to her and she answer'd me of course, and I observed she spoke much plainer the next day. This is a shorter way (as we are but a little distance from the sea) than the method I told you I had so often try'd effectually. We are to go to Alburge to morrow to see a Battery that is erected lately there of six or eight Guns. Who knows but I may find a drowned object to try my experiment upon, I long to succeed in it, but begin to despair, having twiee fail'd, and all that $I$ have got by it, is the fame of having lost my senses, and being calld a Quack. But as I love to make the best of every thing, I comfort myself with thinking (as the man did who broke his legs and blest his stars that it was not his neek.) that if I am mad I am no fool nor ever can be one, if there is any truth in old sayings. 'Thus I get clear of the first imputation, by the help of my own language but am oblig'd, to rid myself of the other to have recourse to the Latin tongue, by proving that the work Quack, like the word 'Tyrant, tho' now it has a bad sense annext to it, had formerly a good one, and that the person who gave rise to this name was an adept in Physick and not superficially knowing in that science as we think the person to be, to whom this denomination is by the world apply'd. The Proof I mention is in Busbequius, who speaks of his Physieian Gulielmum Quackquelbenum. (who had like to have kill'd a Basha; for he expressly says that providence saved him, 
when he was thought past recovery). Qurre, may not a note for the Charliad be drawn from hence, for the etymology of the word (2uack. I am sure you will be prejudiced in favour of this Gentleman when you recollect he was as knowing in Medals as in Physick, for we find him studying that seience at Belgrate with his Master, in quo studio (as he says of him) ad meum sensum mire factum. I think it is time to finish, but must first desire you tell Mr. Dodsley I received his Pamphlet, but desire he would be sure that he does not send me above two ounces, the last being markt more on the cover tho' they did not make me pay for it. If more in future let him send it under two covers.

Yours ete.

N. IIERBERT,

\section{No. XVII.}

\section{FROM THE REV. GLOSTER RIDLEY.}

DEAR MR. PROFESSOR,

I IIAVE a thonsand Thanks to return you for the thousand Entertainments you gave me at Oxford, among these more particularly for Bacchus and Ariadne; so many feet of Guido's designing, and Jacomo Frey's Engraving will make no little ornament in my Nutshell at Poplar; but I am still more indebted to you for that manly and sensible Poem The Judgment of Hercules, I think Mr. Lowth for his own sake should publish it, for there is no doubt but the Copies will multiply, and at last perhaps a very ineorrect one steal into print. One Line I own pretty much entangled me in reading, the last but one in the $3^{\mathrm{d}}$. Stanza, and which, as I am no Critic, and a Stranger to the Idioms of Language, I am not yet quite satisfied in :

Graceful, yet each with different Grace they move.

I am more likely to be mistaken in objecting to it, than Mr. 
Lowth in writing it; but as it is new to me, at least hitherto unobserved, I should be glad to have an authority or two pointed at. Another Favour I am to thank you for, is a Sight of the Samothrncian Mysteries, which gave me that kind of pleasure that I receive from seeing a fine House; I was wonderfully pleased all the while I was conducted thro' the several apartments, but was hurried ton fast from one to another to form an Ilea of the whole, or indeed any thing distinetly of the particulars. However I shall transeribe a passage or two, which if I mistake not will supply you with a little Furniture that you thought you wanted. Armachanus noster (juxta Chronologos antiquissimos) Egialei initium regnandi posuit A.M. 1915, et probabile est sparsim ibi vixisse Pelasgos aliquam multos priusquam inceperit, monarchia Egialei, adeo ut Isis sua mysteria Cabirica Pelasgo tradidit paulò (circa 40 annos) ante initium Egialei. Et sane Sparsi hujusmodi homines faciliùs reciperent externum Osiridis imperium, ejusque sacra, quam unitri sub noto monarehã. Hæc autem benè congruunt cum dietis Herodoti affirmantis, " ommes Græeos, immo ipsos Samothraces a "Pelasgis accepisse orgia, seu mysteria Cabirica." Euterpe. c. 51. Cumberland's Origines gentium, in Appendice de Cabiris. pag : 362,363 . In the next place Reland gives you choice of Etrmologies. the 1. from an Hebrew word that may be wrote thus, Chabirim, Socii, juncti, which hits your mysterious union very well. Or else from another which

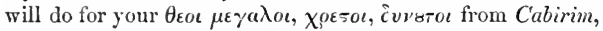
magni, potentes, \&c. Or lastly, from Kebirim quasi Dij Sepultorum, which we won't admit of because it would knock you quite on the head, and only serve the purpose of a parcel of foolish fellows, who pretend to say these Cabiri were Axieros, Axiokersa, Axiokersos and Casmillus, or in more intelligible words, Ceres, Pluto, Proserpine and Mercury, and into these names, Bochart, according to his usual way of unridd'ling, pretends to translate those heathenish syllables. If you please to amuse yourself with these polite and entertaining Gentlemen you may look for Hadriani Relandi Dissertationum Miscellanearum Pars prima ... cujus quinta 
dissertatio est, de Diis Cabiris. And in Bochart's Canaan, lib. 1. cap. 12. With these Belles Esprits-rest you merry! I wish you good success, but I can find no authority either for the number, or the partieular Deities; or rather, I find authorities against you. But these Treatises referr'd to, will aequaint you with them, and was it not for your drudgery of going thro' 'em, I eould wish to see their sense filter'd down thro' your refiners, and their Ore (if any to be found) stampt at your Mint. You may see by this Sentence that I have just been dabbling in them, it will therefore be a very seasonable service to give you a release. I therefore haste to give you Mrs. Ridley's thanks with mine for your late favours, and am

Dear Jo!

Your affeetionate $\mathrm{Fr}^{\mathrm{d}}$. and H.S.

GL: RIDLEY.

No. XVIII.

FROM THE REV. GLOSTER RIDLEY.*

DEAR JO!

I HEREIVITH send you a Letter I have just received 1 from Mr. Wooddeson with some Correetions, which I hope will eome time enough for Mr. Dodsley before the Pin and Needle be printed off. You will be so good to fix upon which is best. You'll see what a strange whim he entertains about your Book, eoneeives that when he is dying he shall think of nothing else but who to leave it to.

I likewise send you a leaf or two of the old papers whieh

* This Letter contained stanzas written on old paper with discoloured ink, intended as a trial of Mr. Spence's Antiquarian skill; it will be seen in the sequel, by another letter, that Mr. Ridley had borrowed Spenser's Faerie Queene of Mr. Spence, and in reading it, tried his hand at imitating the style.-This gave rise to his pleasing poem of Psyche, or the Great Metamorphosis, of which these stanzas afterwards formed a part.-Editor. 
I mentioned to you, found among some of my Uncle's Cart Loads left behind him: the Title to the Bundle, in which these were, promised Verses of Ben Johnson and others found among my (irandfather's V'erses and Papers. But most of these are seatter'd, or mislaid, or lost. Such of the papers (in this Bundle) as have dates to then are from 1612 to 1632. near which time I suppose those without date are to be placed, as far as can be guess'd from the hands and kind of paper. Perhaps they came from Ireland, as they were join'd with a Letter from the Lid. Lieut $t^{t}$. Straflord to King Ch: I. I send you the venerable Originals, supposing that these old, tatter'd, loose leaves are every whit as precious as the Verses thenselves; which, I appreliend, if transeribed fair, upon a sheet of mokern white paper, would, to a true Antiquarian, lose all their beauty, like Dr. Woodwards Shield new seoured. It is quite a mel:meholy thing to see, that time, or tumbling about, has tore off the only significant corner that they had, I mean that, where the Author's name seems to have been written. I will not risque my judgment in Criticism so far as to venture to determine who it was; and therefore content myself with ealling it an Imitation of Spencer. The Metre and Language are something like his. And a very ridiculous Line in the $3^{\mathrm{d}}$. Stanza, seriously in the praise of 'Tobaeco, to me who am a Mlodern, and no Smoaker, sounds as disgustful as Ilomer's Asses and Ilogherds: yet as far as I know, it might not be so harsh, when Tobaceo was all in Fashion, nor indelieate in a Dependant on $\mathrm{S}^{\mathrm{r}}$. Walter Raleigh, the Discoverer of it. For these Reasons I eall it an Imitation of Spencer. But as for Spirit, Genius, Fire, Imagination, Manner, Style, Plot, Conduct, \&e...\&e...\&e.... which you deep Crities love to talk about, tho' nobody understands what you say, but yourselves, I am able to form no judgment about: and I do not blame my ever honoured Tutor neither; it is sheer natural Infirmity. Those points I leave to your Sagaeity: the result, I dare say, will be to think, with me, that it is only an Imitation: and that by an ill hancl. You'll determine it from the want of that Genius, Fire \&e... above mention'd; I, from points more level with my under- 
standing; Such as, 1. I take the Paper to be at least 14 years later than Spencer's death. 2. He would hardly himself say, Written by Edmond Spencer. 3. There are several uncouth Words, which I can't find in the Glossary of Spencer; such as, Suite, heeld, fellones, amane, and some others. $4^{\text {thly }}$. If that be not owing to my unacquaintedness with the Language, there appears to me an affectation of obsolete Words. Who the Imitator was I do not pretend to guess, for there is nothing to guide me but the Corner of a C, or E, or $\mathrm{G}$, or $\mathrm{O}$, or $\mathrm{Q}$. As for C, it is not old enough to be Chaucer's. If $\mathrm{E}$, I have flung out Edmund Spencer. G, O, or Q, may be George Sandys, Ogilby, or Quarls, and I should think it likely to be a Composition of one of them if the Chronology of the paper will not fling them out.

The Conclusion of the Canto, if it be in my possession, is not yet come to hand; and you, I dare say, will have enough of these Hobgoblin Lincs, without giving me the trouble to endeavour recovering the rest. I shall soon beat up your Quarters, being impatient till I get your Book from Dodsley's. Our compliments (as the Phrase is at present altogether) wait on You, Mrs. Spence, and $M^{\mathrm{rs}}$. Collier from my Aunt, $M^{r 3}$. Ridley, and

\section{Dear Jo!}

Your most oblig'd and affectionate

GLO. RIDLEY.

P. S. I most heartily thank you for your most obliging Present, your Book; it is a Present that I value, more than I will tell you of.

Poplar. Feb. 20. 1746. 


\section{No. XIX.}

\section{FRONI TIIE REV. GLOSTER RIDLEY.}

DEAR Jo?

\section{Y}

$\mathrm{OU}^{\mathrm{t}}$ two Professors do me great Honour in bestowing your Criticisms on my little Reptile; a meer piece of chance work without a Plan, intended only, in grateful return for the pleasure you gave me in lending me spenser, to play the fool with you. With this view only (and no other Plan had I) I dish'd down Stanza after Stanza till I got about 18, and then sent you the opus interruptum in hopes that you would have grieved for the loss of the rest. But reading them over two or three times, I was foolish enough to be engaged by them to go on, and finish it as you have it, and now for your Objections, some of which I admit as perfectly just, and others I think I ean defend.

"Imprimis, you seem to me to introduce Psyche under the " form of" a Caterpiller at first, from $\mathrm{St}$ : 7 . and yet you seem " to change her into a Caterpiller, as a punishment for her " Disobedience."-Guilty, my Lord! When I first began I conceived her entirely as a Caterpiller, and never dream'd of changing her, nor eared a farthing what beeame of her: But when I went on, that Objection occurred; however I was willing to hope that she might pass for a Fay at first, who instead of being fair or black, was green and gold \&e.... and therefore in her Metamorphosis say, that her make was new moulded, her colours only left; supposing it neeessary that something sh $^{\mathrm{d}}$ remain, to shew she was, in a Caterpiller, the same that was Psyche before. And to take away, or lessen the Prejudice, against such a kind of Belle, I had inserted a Stanza after the $8^{\text {th }}$. in $w^{\text {ch }}$ I compared her with our old Pict Grandmothers. But that stanza happening to be at least as dull as any of the rest, I left it out, imagining it interrupted the narrative too long. If leaving out the $7^{\text {th }}$. and $8^{\text {th }}$. St: would remove your objection, there would be a double advantage in it, as it would make the length of the whole 
something more conscionable: but $I$ am afraid half the $6^{\text {th }}$ will be left without a meaning too.-However, that's no new thing with me.

" $2^{\text {do }}$. If she could talk when she was only a Caterpiller, why should she be surprised at a Snake's speaking?" You find that I hoped you would have been so good as to let her pass for a Fay when I made her surprized at the Snake's speaking.

" $3^{\text {tio. }}$ Is it Spenser's way to repeat whole Speeches in the manner of Homer? If not, had not you better omit the $30^{\text {th }}$ and $31^{\text {st }} \mathrm{St}$ : or contract them into one?"-There is not one Instance all through the Fairy Queen to justify me: and $I$ told myself of it before; whether the answer that satisfied me will do the same by you I can't say. It is necessary for Anteros to know what was said: and those Lines were Scripture to Psyche which she repeats with a religious Exactness. With which the Freethinking Devil makes himself merry. Yes.

" $4^{\text {to }}$. Is puissant (St: 5 .) used as 3 syllables by Spenser?"

Then got he Bow and Shafts of Gold and Lead,

In which so fell and puissant he grew,

That Jove himself his power began to dread.

Spoken of Cupid, in Colin Clout come home again. And Puissance I remember is used somewhere in the first Book, and $I$ believe $1^{\text {st }}$ Canto, as 3 syllables: but almost every where else only as 2 .

" 5 to. Is new Worlds clear enough?"-I dare say not, because you ask the Question. Do alter it, for the Duce take me if I know how to do it.

" $6{ }^{\text {to }}$. Have you writ Ferm or Form?"-Ferm.

" $7^{\text {mo }}$. Would not pass do better than leap? Stan. 19.9." - Pass is already in the same Line.

" 8 vo. Is it raught or saught in St: 14.1 ?"-raught, Spenser's uniform prætoritum of the verb reach ; as we still form taught of teach.

" 9 no. Should not you point out, that it is the Celestial 
Venus, St : 39 ?" I, who happened to be in the Garden when she eame, knew it was the Celestial Venus: but 1 had forgot that it was not so plain to any body else. The kindness of eoning to seek her (Psyche) is a cireumstince I would preserve if I could-Suppose it be-The lleav'nly Queen who songht her with her Son_-or any other way you think proper.

The grand Objeetion is the first, which is an Error in the first Coneoction, and $I$ an afraid whoever reads it, if any body will have patience to do so, will in spite of my 'Teeth take Psyehe for a Caterpiller, when I now intend she should be as charming a Girl as ever was seen. And the moral intended in St: 49. is, that the extent and Capacity of the Soul is diminish'd, from what it was, even as a Caterpiller is less than a man; but some faint and dim resemblance contimues in its colours or faculties.

I shall be glad to see the Fardel whenever you will combine together to slip out. Be sure you let me know 2 or 3 days before, that if I am engaged and ean not put it off, I may save you the trouble of coming by returning an answer. Next Thursday or this day sen'night, April $2^{\mathrm{d}}$, I an engaged. And every Friday in Lent $I$ eatechise in the afternoon.

$$
\text { I am, }
$$

Dear Jo: with Compliments

Yours affectionately

Poplar March 26.1747.

GLO : RIDLEY.

\section{No. XX.}

FROM MIR. ROLLE.

DEAR JO

$$
\text { Monk } k^{\text {ton }} \text { Aug : } 15^{\text {th }} 1747 \text {. }
$$

IIAD the pleasure of yours some days since, and am
surpriz'd at what you say in the elose of it, that you are
setting out for Birehanger, without by mistake you mean G.
Horwood. For God's sake what is it you go to Birchanger 
to see? your Plantation? a Low, Lean Switch or two, and which If $I$ had not too great a regard for Scripture to make use of it on so low an oecasion, I shou'd not scruple to Term, a Reed shaken with the wind. My Rabbits whom you talk so debasingly of, I wou'd undertake were they in your neighbourhood wou'd be so many wild Boors of the Forest to root em up, tis well for the Trees they are at 200 miles distance, Fortunate quod non Armenta ${ }^{\text {sc. }}$ !

My Mother's Story which you desire to have related for Mrs. Spence's sake, is briefly this. On the Eve of Last Midsummer was twelvemonth Susan Turner too inquisitive about Futurity, watch'd near the Church Porch of the parish of Monkekinton, to see who went thro' the said Porch into the Church, which it seems was a eertain token of their mortality the year following: as our parish is but small, she wisely foretold but few deaths; and as predictions with probability on their side are most likely to be fulfill'd; of the 4 persons she pretended to have seen, two were expiring at the time and died that very night, and the two remaining, one of which was my mother were by far the Eldest people in the Parish: However they are I thank God still both alive, and my mother, however a pretty deal shock'd last year with the Prophecy, is at present very well and like to live in spite of it; indeed she hath now fairly outliv'd the force and date of it, and I hope two such disappointments will be a discouragement to a practice, which hath been known sometimes to give people a great deal of real uneasiness.

\section{No. XXI.}

FROM MR. WHEELER.

CONTAINING AN ACCOUNT OF THE MAN OF ROSS.

DEAR SIR

BEFORE I can have any pretence to ask any favour of You, I must grant one you have so long ask'd of me: I mean some faint Idea of $\mathrm{M}^{\mathrm{r}}$. Keirl, better known in the World 
by the Man of Ross: A Title of Distinetion I believe he well deserv'd, having not left his fellow behind him in that 'TownAn acquaintance of mine tells me he knew him personallyThat he was a very sober, temperate, regular, hmmane, generous, religious, sensible Man-extremely plain in his dressand gentlemanlike in his behaviour-respected and earess'il by all who knew him; and applied to by rich and poor for his direetion and Adviee.-IIe wals remarkably IIospitable-kept a plain plentiful table; Thursday was a Publie Day, for the Neighbours, his 'Tenants, and the Poor.-Tho' he was passionately fond of Arehitecture, yet he was contented to live in an Old Ilouse; it was large enough, and that was the particular he regarded most. Ile kept very good hours, and was abed betimes, except his friends, who knew his Passion, enter'd upon the subjeet of Building, when they had a mind to have an hour or two extraordinary with him. I've heard, to encourage a Gentleman who wanted a better Iouse, he wou'd offer to advance a moderate Sum of Money, provided he shou'd plan and supervise the Building. I'm told his taste was often gratify'd without any expence, for no Gentleman wou'd fix on any Plan, before it had reeeiv'd the Approbation of Mr. Keirl. He was in Herefordshire, what $\mathrm{Mr}^{\mathrm{r}}$. Prowse is in the County of Somerset.

IIe had a singular taste for Prospeets: and by a rast plantation of Elms, which he has dispos'd of in a fine manner, he has made one of the most entertaining Scenes the County of Hereford affords_- His point of View is on an Eminenee which he has wall'd in and dispos'd of into walks; the Spot is about 6 or 8 acres. Thro the midst of the Valley below, runs the Wye, which seems in no hurry to leave the Country, but, like a Hare thats unwilling to leave her habitation, makes a hundred turns and doubles; He has beautified the Churchyard with fine plantations-and the extraordinary growth of ev'ry thing he set, gives him the reputation to this dity, of having had a lucky hand. The inside of the Chureh has shar'd his generosity too in a gallery and Pulpit. After all that he has done for the Chureh and Parson, wou'd it not vex one if some avaritious or necessitous incumbent shou'd 
cut down these fine Elms, which are for the most part planted in the Chureh Yard and Glebe?

Though he was a friend to all mankind, yet there was one set of men, he tried to ruin, the Attorneys in his neighbourhood. It was very rare that any difference terminated in a Lawsuit. He was general Referee; which paid no small compliment to his Abilities and Integrity_I have been told his Pnblic Charities kept pace with his private benefactions-But which of the Almshouses was most favour'd by him at Ross I am at too great a distance to learn. He was a considerable contributor to a long handsome Causeway which leads to the 'Town; which with the stately Avenues of Elms planted by it, gives the Traveller a very favourable prejulice to the place.-At Christmas he distributed a great deal of Money and provisions to the poor, to make them share in the eheerfulness and jollity of the season. All this and much more he did tho' his income was no more than $600 \mathfrak{E}$ a year. 200 of it lay abont Ross.-Ile died a Bachelor: and left his Estate to $\mathrm{Mr}^{\mathrm{r}}$. Vand ${ }^{r}$. Keirl, who was bred a Confectioner at London-It was often suspected in his Neighbourhood, that he was a natural Son of the Old Gentlemans-His heir was an extravagant debanch'd young fellow-much in debt before his accession to the Estate; and the same temper continuing after his coming into possession, soon reduc'd his Income.-Ile left 2 Sons and a Daughter. The Second Son, tho' without a fortune, lives in the same IIonse, in which the Man of Ross liv'd, and keeps open house for all comers-It is I think reckon'd the best Inn in Town.

These are the few hints I eou't collect of the man of Ross; I wish I eou'd help you to materials suflicient, to give his Picture at full length to the World___For I think he was a Credit to the Age and Place he liv'd in.

And now, Sir, to the favour I have to beg of you: Mr. Archdeacon Shakerley the Bearer of this, is upon the point of beginning the 'Tour of France and Italy; and to make it to good advantage wou'd gladly receive your Instructions and Recommendations; In which latter you may say as many 
fine things of him as you please: for he is in good truth, a worthr, sensible amiable man. He is besides all this, one of the dearest friends I have in the Work._- If he had met with rou in Town sometime ago, as I intended he shoud. by delivering a Letter to yon, you woud have in all probability made the same report of him to me- And if he stays long enough to be acquainted with you. I make not the least doubt of the thanks of Both, for the mutual Aequisition you have made-

I am, dear Sir, in great haste

$$
\text { Yours most affectionately }
$$

$25 \mathrm{Feb} .17+3$.

R. WHEELER.

\section{No. XXIr.}

\section{FROM MIR. R. DODSLEY.}

DEIR SIR

Pall Mall Oet $\mathrm{T}^{\mathrm{r}}$.20 $\mathrm{d}$ 1its.

W

HILE you are planting the Groves, directing the Walks, and forming the Bowers that are in all probability to afford you a Retreat for the whole of your future lite; you seem like a man arriv'd at the end of his Labours, and just begimning to enjoy the fruits of them. If I did not love you, I should certainly enry; but as it is, I heartily rejoice; and only wish I was with you to partake of the Pleasure, which I am sensible you mimst at present enjoy. But here an I, ty down to the Worhl, immerst in Business. with very little Prospect of ever being able to disengage myself. "Tis true, my Business is of such a Nature, and so agreeable to the Tum of my Minl, that I have often very great Pleasure in the l'ursuit of it. I don't know but I may sometimes be as much entertain il in plamning a Book, as you are in laying out the Ilian of a Garden. Yet I don't know low it is, I cannot help languishing after that Leisure which perhaps if it was in my possession I should not be able to enjoy. I an afrail the Mim who would truly relish and enjoy Retirement, must be previously furnish'd with a large 
and various Stock of Ideas, which he must be capable of turning over in his own Mind, of comparing, varying, and contemplating upon with Pleasure; he must so thoroughly have seen the World as to eure him of being over fond of it; and he must have so much good Sense and Virtue in his own Breast, as to prevent him from being disgusted with his own Reflections, or uneasy in his own Company. I am sorry to feel myself not so well qualify'd for this sacred Leisure as I could wish, in one respect; but glad I have a Friend from whose Example I cannot but hope I shall be able to improve.

\section{No. XXIII.}

\section{FROM MR. R. DODSLEY.} SENT you last week by Thatcher's Barge all your Parcels, in which were included two Epping Cheeses which Mrs. Dodsley desires Mrs. Spence will be so good as to accept. I hope you have before now rec ${ }^{\mathrm{d}}$ all the cargo safe exe $^{t}$ the Gr H. I have this day sent the Pope's Works (which eame from Mr. Warburton) down to Hungerford, to go by the same Conveyance. I am afraid my design on the Banks of the Thames will not proceed to Execution, the Landlord and I not having yet agreed. As the idle time of the year is now come on, I have begun it with the most idle of all Productions, a Love Song: I intend it for Mr. Tyers, to be sung at Vaux-hall. Pray tell me whether 'tis good for aught or not.

I wrote it, alas! not from any present feeling or sensations, but by recalling past Ideas to my nuind; and therefore it may possibly want that passionate Tenderness requisite to the subject: however I think it so much too young for me at present that I shall not let Mr. Tyers or anybody else know that it is mine. 


\section{MUTUAL LOVE.}

A song.

WheNéer I meet my Carlia's Eyes, Sweet Raptures in my Bosom rise,

My Feet forget to move;

She too deelines her lovely head,

Soft Bhushes o'er her Cheeks are spread;

Sure this is Mutual Love!

My beating IIeart is wrapt in Bliss, Whene'er I steal a tender Kiss,

Beneath the silent Grove:

She strives to fiown, and puts me by,

Yet Anger dwells not in her Eye;

Sure this is mutual Love!

And once, $\mathrm{O}$ once! the dearest Maid, As on her Breast my Head was laid,

Some secret Impulse drove; $\mathrm{Me}$, we her gentle Arms earest, And to her Bosom elosely prest, Sure this was mutual Love!

And now, transported with her Charms,

A soft Desire my Bosom warms

Forbidden Joys to prove:

Trembling for fear she shonld comply,

She from my Arms prepares to fly, Though warm'd with mutual Love.

O stay! I ery'd-Let IIymen's Bands . This moment tye our willing Hands,

And all thy Fears remove:

She blush'd Consent with modest Grace, And sweetly in her glowing Face,

I read her mutual Love. 


\section{No. XXIV.}

\section{FROM MR. ROBER'T WOOD.}

\section{DEAR SIR}

London September 251749.

T HOPE you'll excuse my breaking in upon your retirement with my impertinence; in short I cant help begging your assistance in a scheme I am about undertaking, which is thus, I set out in two days for Paris, and so on to Rome, to overtake there two Gentlemen (Mr. Bouvry and Mr. Dawkins) who have been mostly abroad for some years, and propose extending their ramble a little further; accordingly are to have a ship ready in Spring to set out from Naples to make the tour of the Mediterranean; we propose visiting Athens and the Greek Islands; some parts of Asia Minor, and Egypt, if possible Palmyra; and in general most of the Classical Countries within such a tour; without going much into the Inland parts. I have bought a Collection of the Greek and Latin Classics to come out in the ship (which we intend to have sent from hence) and such Instruments as are necessary for measures; we take from Italy a Person who draws well; I could not think of any body fitter than Boura at Turin who us'd to teach in the Academy; as he takes views pretty well, is an Architect and Engeneer; I can't tell you what I would trouble you about better, than by telling you my plan of amusement; which is in general, to compare the Antient with the present face of the Country; the Greece of the Poets and historians, with the Greece we shall see; when I was last in those Countries I amus'd myself, (in rambling over the Country about Ida, the Simois and Scamander, $\& c$.) in considering Homer, abstracted from his poeticall merit, as writing the Account of a Campaign ; and making out a Plan of Troy and the environs from the Iliad, began to compare it, as far as I had time, with the present aspect of that Country; and found so exact a resemblance that I should be greatly tempted to pursue the same plan with more time and lejsure; I mention this as what is to make my principal amusement, if your leisure from any 
thing more important would allow you, could you now and then look into the classicks, to give me any hints I shonll be much oblig'd to you; if my going into those countries, can make me understand better or have a stronger relish for some of its antient writers, I shall think my time at least innocently spent, not without pleasure; if you at your leisure could favour me with a line under Cover to Charles and Richarl Selvin at Puris, and at the sume time give me amy particular commission for yourself you'll much oblige

Your most Obed'. humble Serv'.

\section{ROB $^{\mathrm{T}}$. WOOD.}

\section{No. XXV. \\ FROM DR. ROBERT LOWTII.}

DEAR MR. SPENCE

Turin July. $11^{\text {th }}$. 1749 .

Y OU know me so well, that you will rather be surpris'd at hearing from me at all, than wonder that 'tis so long first : besides I told you that I must have time to take a view of the place, before I could give you an acet. of it and of your Friends. I must thank you in the first place for introducing me to Mr. Dom-Ville, who is a very worthy, sensible, and agreeable man. If was very glad to hear from you, and was extremely pleas'd with your Book which I gave him. Ife tells me he has not English enough to set down to read it through, without a great deal more leisure than he has at present: but he has been very busy in looking it over and consulting particular places by the Index and Plates. He desires you would aceept of his Compliments, and many thanks for your Present. From what I have said you begin to be in pain for your Friend Count Richa: he died here three or four days before we came. He had been confined for some time; and as the beginning of his illness was attended with some very odd circumstances, I'll give you as good an acct. of it as I have been able to get. Four or five 
Months ago the Princess of Carignan happened to observe that some of the China that stood in one of the Anti-Chambers was missing, and that it continued to decrease by degrees; she took notice of it, and enquiry was made about it among the servants: they could give no acct. of it; but one of them to clear himself and his Comrades of Suspicion was resolv'd to watch it, and hid himself in the room for that purpose. IIe was much surpris'd to see Count Richa, the first time he came to visit the Children as usual, as he return'd thro' the Room, go to the place where the China stood, choose ont a piece or two of it, put it in his pocket, and carry it off. The Fellow did not care to risk his Credit against the Count's, by declaring immediately what he saw : he only saicl, he knew who had the China, and if they would send him in all the Messages to the houses about the town, he should soon be able to get very satisfactory intelligence of it. It was not long before he had an errand to Count Richa's, where he saw all the China that was missing openly displayed upon one of his Tables. When the story was known, ev'ry body look'd upon it as a plain Indication that the Count's head was disorder'd: however the Prince of Carignan immediately forbid him his house. The Count hardly appear'd abroad afterward : his illness soon took a different turn; his health decay'd apace, and at last he died of a Dropsy. -As to the rest things stand here pretty much I believe as you left them: our Governors are Count Salmure and the Chev $^{r}$. St. Sebastian. I long to find out some of your walks, which look very pretty from my back window: I have not been able to go out to the other side the Po above once or twice: there is no walking here at this time of the year: the heat now begins to be insufferable. Oh that somebody would set me this moment under one of your Trees at Byfleet!-Present my Respects to your Good Family. Let me hear from you.

Your's

R. LOWTH. 


\section{No. XXVI.}

\section{FROM DR. ROBERT LOWTH.}

\section{DEAR JO}

Naples March 1. 1750.

WAS afraid that something had happen'd to you, as it was so long before I heard from you. This is one of the very great inconveniences of being so punctual as you are: your friends are all alarm'd, whenever your Letters are a post or two later than ordinary; the uneasiness it gives them is well-founded, but had better be spared. Those that are so good as to be concern'd for me, I use more kindly; I teach them not to be in care about me, tho' they don't hear from me in a twelvemonth. I am very glad you are got well again, and I hope your exercise in the Country and your journeys between your Villa and Town, will perfectly establish your health. I read the description of your Garden to Sigr Domsille; he found it to be the same in the main that you had talk'd over with him, 8 or 10 years ago: I left him well at Turin about a Month since. He gave me some information with regard to those friends you enquir'd after: $M r$. Lanskarounski is now in the Saxon Service; I think he made a Campaign or two in the beginning of the war in that of the King of Sardinia: Mr. D'Erlach died somewhere in Lombardy, 6 or 7 years ago, of the smallpox. I must not forget your old flame, the Princess of Carignan: She has lost I believe a good deal of her beauty, being now pale and very thin; but will aluays retain her agreeableness. She lay in, while we were at Turin; and has now about 6 Children.

A good part of this dlay and yesterday I spent in the company of your Friend $\mathrm{Sig}^{r}$. Camillo Paderni : he is settled at Portici in the King's service, and is employed in making Drawings of the Antiquities found in Herculaneum, of which they are preparing to give the world a large account. He has been there upon this business above a year and half. He has receiv'd your Book from Mr. Nash, who was here lately. Sigr $^{r}$. Camillo is very well with the King; has access 
to him at all times, and frequent conversations with him: he has presented your Book to His Majesty, as an example proper to be follow'd for the beauty of the Paper, Impression \&e. in the work which they are now going to put to the press. I hear no great account of the abilities of the person that is compiling this work; besides that, he is old and infirm, and there is a great variety of matter, too much for any one person to undertake. Your Friend's part will, I doubt not, be very well perform'd: he shew'd us some of his drawings, particularly that of the Equestrian Statue; which is I believe by much the finest thing they have found; it was perfect, except one land, and the two feet, which have been supplied. The Horse is much beyond that of M. Aurelius in the Capitol. This is of marble, and as big as the life only. The Inscription is: м. Nonio. M. F. BaLbo. Pr. Pro. cos. Hercvlanenses. Among his drawings I could not help observing, as I had done in the original Paintings, two Female Centaurs, which are animals I was not before acquainted with. These are among the copies which he is taking in eolours of the best of the paintings: they seem to me to flatter the oriminals. To tell you the truth, I don't vastly admire the Pictures in general : most of them are certainly very bad; some single figures are prettily enough design'd; the Chiron and Achilles has some Life and Expression, but is not well design'd in the whole; and is I think far from deserving the great commendation I have often heard of it. They have lately been digging in another part of the Herculaneum; but I don't find they have had any great success. Sigr. Camillo has been very obliging in aecompanying us thro' the several lights of the place; and to day has been with us to the top of Vesuvius, which he had not seen before. He desires his Compliments to you. I should have told you before, as you desir'd particularly to be informed, that he has long ago drop'd his design of publishing a Collection of Basso Relievos. We have been here a week, and shall stay as much longer, to see the place and the neighbourhood. We then returu to Rome for two months: we staid only one day there in coming, and took one great gape at some of the prin- 
cipal Buildings and Ruins. In our way we staid a week at Bologna, and work'd very hard all the while. We are forced to leave Venice quite out of our plan; we stay but a fortnight at Florence. Pray sit dou'n immedintely, and write me a Letter for Dr. Cocchi. We are to be in Englind the ent of June. In the mean time, and ever believe me, Dear $J_{0}$,

Your's most affectionately

R. LOW'TH.

Direct, recommandée à Mons. Le Marquis Belloni à Rome.

I had almost forgot to tell that I asked $\mathrm{Sig}^{\mathrm{r}}$. Paderni what he thought of the engravings in your Book: he conmended them much in general, spoke in high terms of many of the small pieces, but did not seem to think so well of the large figures; I asked lim particularly of the Basso Relievos; he thought one much better perform'd than the other; you will know which; I have forgot.

\section{No. XxviI.}

\section{FROM STEPIIEN DUCK.}

DEAR $s^{r}$

Kew. Decem. 5. 1750.

I

IIAVE had thoughts many times of coming to see you, but the exceeding bad weather and some business have hinder'd me. However, if nothing extraordinary happens, I intend to convinee you that I am not merely a Summer Bird, by waiting on you in the very depth of winter, probably at the lutter end of next week-The king (God eternally bless him) has kindly given me occasion to buy a new Horse, by making me Chaplain to a Regiment of Dragoon Guards, which has fully made me aments for being broke. And the favour, I think, is doubled, because it was granted without any knowledge or solicitation of mine. But thongh the Government saves $60 \mathfrak{E}$ per $A \mathrm{nn}$. by this, and though I think 
upon the whole, it is but a piece of justice (as I bought the former Chaplainship) yet it has moved the Envy of some persons, and made 'em strive to be witty upon my change of life, as perhaps you have seen in the Magazines-I don't think these Writers deserve any Answer, or if they do, I would give them only the following.

\title{
You think it (Censor) mighty strange \\ That born a Country Clown, \\ I should my first profession change, And wear a Chaplain's Gown! \\ If Virtue honours the low Race From which I was descended, If Vices your high birth disgrace, Who should be most commended.
}

Pray make my kind Complim ${ }^{\text {ts }}$ : to your good Mother and Cousin, and believe me to be, with great Truth,

\author{
Dear $\mathbf{S}^{r}$. \\ $\mathrm{Y}^{\mathrm{r}}$ most affectionate \\ and faithful humble Servt. \\ S. DUCK.
}

No. XXVIII.

FROM STEPHEN DUCK.

ACCOUNT OF THE MAN OF ROSS.

DEAR $\mathbf{s}^{r}$

Kew. Jan. $1^{\mathrm{tc}} .1751$

THIS waits on you with my best wishes for a happy I year to you and yours. May all your rational, animal, and vegetable families thrive and be healthy. I think this warm wet winter very favourable for your new plantations, your Trees will doubtless take root and flourish ; tho' I fancy 
a little dry frosty weather would more contribute to the health of human creatures, at least I believe it would be better for my Constitution, for I impute a bad Cold that I have had since I saw you, to the very wet weather which we have had in these parts : and my feet have been very wet in my frequent ambulations to Twickenham, where I often improve the flavour of a glass of Wine with your health.-According to your desire, I have enquired of Mrs. Shepherd about the Mian of Ross. The particulars which I have learned are not many, nor very important. He was, it seems, a tall thin Man; sensible and well bred; and went so very plain in his Dress, that when he work'd in the fields with his own Labourers, (which he frequently did) he was not distinguished from them by anything more than a certain Dignity in his Air and Countenance, which always accompanied him. He kept two public Days in a Week; the Market Day, and Sunday. On the former, the Neighbouring Gentlemen and Farmers dined with him; and if they had any differences or disputes with one another, instead of going to Law, they appealed to the Man of Ross to decide and settle them. And his Decisions were generally final. On Sinday he feasted the poor people of the Parish at his House; and not only so, but would often send them home loaded with broken meat and jugs of beer. At these Entertainments he did not treat with wine, but good strong beer and Cyder. On these two Days, great plenty and generosity appeared; at other times, he lived frugal. He had, it seems, (like a worthy Gentleman of my acquaintance) a most ineorrigible passion for planting, insomuch that he embellished the Parish with many beautifill Groves of Trees; some of which were a Mile in length. My Gossip has not informed me of any Mountain or Camp that he adorned with Pines, but She says there is a large Common in the Neighbourhood of Ross, which at this day, rejoices under the Shadow of his Trees. In Works of this Nature he chiefly employed very old Men, such whose Age or infirmities rendered them incapable of doing such very hard labour, as the Farmers required their Servants to do. With these old Men he would frequently work with a spade himself; pay them amply for their Labour; and often feed them 
at his own Table. This virtuous memorable Gentleman was once taken up for a High-wayman.-Dut I have not room to tell You any more than that I am

$D^{r} S^{r}$

Yor. most affectionate \&c.

S. DUCK.

\section{No. XXIX. \\ FROM HORACE WALPOLE.}

DEAR $s^{r}$

Arlington Street June $3^{\text {d }} 1751$

T HAVE translated the lines and send them to you, but 1 the expressive conciseness and beauty of the original and my disuse of turning verses, made it so difficult, that I beg they may be of no other use than of shewing you how readily I complied with your request.

Illam quiequid agit, quoquo vestigia vertit, Componit furtim subsequiturque decor.

If she but moves or looks, Her Step, her Face By stealth adopt unmeditated Grace.*

* Mr. Spence appears to have applied to other friends, beside Mr. Walpole for a translation of these lines, and to have translated them himself; I find the following among his Papers.Editor.

Whate'er she does, where'er she bends her course, Grace guides her steps, and gives her beauty force.

Whate'er she does, where'er she moves, a Grace,

Slides in to give it form, and marks the trace.

G. R.

A secret Grace attends her charms inbred,

Work in each action; in each footstep, tread. 
There are twenty little literal variations that may be made, and are of no consequence, as move, or look; air insteal of step, and adopts instead of adlopt: I don't know even whether I wou'd not real steal and adopt, instead of by stedth adopt. But none of these changes will make the eopy half so pretty as the original: But what signifies that, I am not obliged to be a loet because 'Tibullus was one, nor is it just now that I have discovered I am not.* Adieu

\section{$\mathrm{Y}^{\mathrm{rs}}$ ever}

\section{WALPOLE.}

P. S. was not Mfilton's paraphrase, " Grace was in all her steps, \&c," even an improvement on the original? It takes the thought, gives it a noble simplicity, and don't screw it up into so much prettiness.

In ev'ry motion, action, look, and air, A secret grace attends and forms the Fair.

S. D.

With every motion, every eareless air, Grace steals along, and furms my lovely fair.

J. s. letter.

- The following verses by Mr. Walpole, were enclosed in this

\section{INSCRIPTION}

FOR THE NEgLECTED COLUMN IN THE PLACE ST. MARK AT PLORENCB.

EscAP'D a race, whose vanity ne'er rais'd

A monument, but when themselves they prais'd,

Sacred to Freedom let this column rise,

Pure from false trophies and inscriptive lies:

Let no enslaver of his country here

In impudent relievo dare appear:

No Puntiff by a ruind nation's good

Lusting to aggrandize his bastard brood;

Be here no Clement, Alexander seen,

No pois'ning Cardinal, or pois'niug Queen;

No Cosmo, or the Bigot-Duke, or lse

Great from the wounds of dying Liberty : 


\section{No. XXX.}

\section{FROM MR. E. ROLLE.}

YOU cant imagine, dear Jo, what a figure it gives one in

Devonshire: where I now am, to receive a letter with that outlandish mark upon it: I am vastly obliged to the good old lady for having our correspondence so much at lieart and to yourself for so readily complying with her. An Epitome of Oxford do you eall what you have with you? I could hardly have thought Alma Mater had so many children abroad, take all Europe together; dont so many English faces tempt you sometimes to an English conversation? I can hardly conceive a dozen true Britons abroad together, without Their allowing themselves now and then an hour's chat in a language they are at no pain to talk in: is it not timide verba intermissa, \&c you must eertainly relapse sometimes by stealth into a few snatches of English: I am with Mr. Rolle now, who desires his services to you. The sight of your letter reviv'd in him for a time his old affection for travelling, his last resolves were to spend a month or two next spring in France, and he hath promis'd I should be with him: Est il possible, I should be able to think with the least probability of a thing I never durst do more than admire before! As incredible things have happened, and per-

No Lorrainer-One flatt'ring Arch suffice

To sum his virtues and his victories :

Beneath his influence how commerce thriv'd, And at his smile, how drooping Art reviv'd;

Let it relate, e'er since his rule begun,

Not what he has,-but what he shou'd have done.

Level'd with Freedom let this pillar mourn;

Nor rise till the bright blessing shall return;

Then tow'ring boldly to the skies proclaim,

Whate'er shall be the happy hero's name;

Who a new Brutus, shall his country free, And, like a God, shall say, LEt there be Liberty ! 
haps some years since you as little thought of it yoursulf. What think you of the old gypsy? the seeing one of that order lately, put me in mind of the intereourse you hau with one at Oxford once, dont you remember she foretold your going abroad precisely : one would almost really be inclin'd to think they did not always talk at hazard, for my part I dont think it unlikely I shall live to see you Mediagoras (was not that the hard word she grave your preferment?) You wont be so ummercifull as to expect any account of new books from hence, where the talk never rises above the common country topies, and where I never see a book beyond two or three little travelling Authors, I brought with me, wrote every one of 'em the t'other side of Anno Dom:-I forgot to mention in my last, that of the $200 £$ per $A n$ : left to the University $20 £ \mathrm{pr}$. an : is alded to the Poet: Prof. I dont suppose it will be any advantage to it in your time. Tho I dont know whether the estate langs upon more than one life.-New Coll: a month since was worth four $(\mathrm{r}$ : Com: and $\mathrm{S}^{\mathrm{r}} \mathrm{W}^{\mathrm{m}}$ Fiteh under Mr I'rice, Mr Brideoake hath one Gentleman C : and the others are with Mr. Morrison, he will in all probability be well stock't soon, he is in favour with Dr. Burton, and the Warden tis thought rather in his interest. There were rooms taken for two more, and it does not seem unlikely from such a sudden flow, that we should have our share again :-

$$
\begin{gathered}
\text { Farewell, Dear } \mathrm{J}_{0} \text {, } \\
\mathrm{y}^{\mathrm{rs}} \text { affec : }
\end{gathered}
$$

Aug : 12

E: ROLLE.

\section{No. XXXI. \\ FROM MR. EDWD ROLLE.}

MY DEAR JO.

Mayence July $12^{\text {th }} 53$

I HAD the pleasure of two Letters from you at Venice, 1 the last dated May the $9^{\text {th }}$. and expected one at Frankfort, I think in my last from Florence I told you how it might be 
directed to me there, but was disappointed of that and another, I hoped to meet with there firom College, so that I am now a great deal behind-hand again with the world, and am like to be so for some time, without you will take pity on me, and as soon as you have this, write, and direct to me, with Mr. Walter, chez Mons ${ }^{r}$ Hope Banquier à Amsterdam : I write you this from Mayence, for we left Frankfort yesterday and not before, tho I writ you, I thought we should do so above a fortnight ago, and I intended to have writ this to you upon our voyage down the Rhine, but God Almighty only knows why Mr. W. will stay here to day, by which means as here is nothing to see I have some hours to write letters in.

Dont think I am like to let you go off without being troubled with a long account of our Journey, which we travellers think others will concern themselves about as much as we ourselves do. We left Padua, and with it Italy and all virtù Helas! monday three weeks, and came thro Trent, Inspruc, Munic, Ausburg, Stutgard, Heidelberg to Frankfort last Saturday, a line of about 600 miles length. We were fiom monday in the afternoon to the tuesday sen'night in and among the Alps, a much greater length than thro' Savoy but the roads much better, tho the prospects, if you will except a little of $\mathrm{II}^{\mathrm{t}}$ Cenis, quite as savage and agreeable. You meet with too in this road, which I see you pish at so nuch, a great number of very good things, I mean by this the solid comforts of eating, drinking, and lying well; in this last respect indeed you are at least as well again off as in any country whatever, for you have a very soft bed above you as well as one below, and you stew in the finest manner in the world between down on all sides of you; none but Rabelais and the Germans seem to know the value of a Goose's neck! Then besides all this, the good women whereever you come are so obliging, I mean so willing to oblige, that they talk on to you an hour together before they find out that you dont understand 'em. In the Tyrol in particular where you meet every where with a kind of savage, or rather pastoral simplicity and good humour, and than which I'll be burnt alive if Arcadia was a bit better, with scarce a 
woman with a shoe or stocking, but except this, very comfortably drest, and with some of the most whinsical and Mary Queen of Scots' caps that ever were seen, I am mistaken indeed if you would not have been glad to have trac'd up with me the Adige to its souree, where it could run through a quill, tho it makes such a bluster afterwards. Indeed, indeed, $\mathrm{J}_{\mathrm{o}}$, I should like the $\mathrm{Al}$ 's very much if it was not for the hills, or as Destemona lov'd Othello, I should adore 'em, if' they would not frighten one so with all their beauty and fierceness. Oh how I long to see you, and to despise you most infinitely for not having seen the German Alps and The Tyrol! On coming down Mount Brenner, which is the mount Cenis of that country, I gather'd a cone for you, from such a Larch-tree as you never will be master of whilst you live, and there were groves indeed of 'em. I took my leave of the $\mathrm{Al}_{\mathrm{p}}$ (for poor things methought after all I was sorry to quit 'em) with a sigh, and a short copy of verses, which probably will be the last I shall ever compose, as I shall hardly ever see the subject of 'em any more, and which if I live to see you and Mr. Duck again, I will show you, for I dont design to fill my paper at present with foolish verses, which will do better and be somewhat more natural when we go up together to Spence's point, tho' this is, God bless it! but a poor image after all of mount Brenner, \&c.

I write this, as I said from Mayence, but shan't put it into the post till Cologn, which is in the post road to England: How shall I do to hear from you, if you should be gone from home on your Villeggiatura, and of course not have room to answer this in time? Dont fail, if you ean write; for which reason I will give you the most certain acc of our motions I can, but after all uncertain, for Mr. W. will never determine beforehand, or say at least that he hath done so. But we shall get to Spa probably on Sunday night the $15^{\text {th }}$, stay, here some days; and by the end of the month at farthest be at Amsterdam, and thence go thro the Towns of Ilolland, to Brussels and to Calais, I lope by the middle of next month ; if the letter should come a little too late, I will leave word at Amsterdam for it to follow us. 
So far I writ of my Letter at. Mayence, but design'd not to finish it, till I conld do so from whence I direct this to you, viz. on the Rhine. I have been now one day upon it, and shall be one more at least, but most probably a third, to Cologn. You'll tell me you've been upon the Thames (The Thames I tell you is a puppy!) a Swan-hopping and eating cold pidgeon pye. But what is that to sailing down the Rhine, than which very few rivers in Europe draw a finer humid train after 'em, with sloping vineyards ever on each hand of you, having a pretty Town perpetually before you in view, before you have lost quite what you left behind you, having a large barge divided into 3 or 4 commodious apartments, eating cold roast mutton and cucumbers, and drinking some of the most wholesome wine in the world, that which grows on the sides of every hill we pass by. But enough of this I must not insult too much. With all compliments as usual, my Dear Jo,

$\mathrm{Y}^{\mathrm{rs}}$ ever affectionately

E: ROLLE.

P. S. Jnst this moment our good friend the Rhine receives the Moselle which runs into him, and whose assistance poor thing, be sure he wanted very much, to make himself great when he was a little Sea before, tis just like **** having estates left him, who had before $10,000 \mathrm{p}^{r}$ an. And yet if you was to see one of those floats of Timber which I see just now, of a quarter a mile long (tis but a small one) with wooden houses on it, with windows hens and chickens, several families \&c \&c \&c, you'd say after all, his affairs must be a little encumber'd, notwithstanding this fresh supply.

Cologn July $15^{\text {th }}$ 
No, XXXII.

\section{FROM MIR. TIIO SOOKE.}

\section{DEAR SIR}

T must be a great pleasure to you to be employ'd in the 1 delightfull work of Gardening and espeeially for so excellent a friend. Yet give me leave to say it is no new profession you have taken up, but an old one, for if the luman mind be a garden where "flowers and weeds promiscuous shoot" and which requires cultivation, you have been a Gardener a long time.

You good $\mathrm{S}^{r}$ Beaumont! were by IIeav'n design'd T' adorn and eultivate the Human Mind :

To teach the Great, how Greatness to employ, Beam like your noble Friend, the heart-felt joy!

With views divine their riches to dispense,

And win true Glory by Munificence :

The spotless Maid, preserv'd from ernel harms,

Warm'd by your precepts, seeks fair Virtue's charms.

You show not virtue with a frowning mien,

But simple as herself, and as your soul, serene.

I am extremely glad my father is so well situated, and do assure you they shall have my consent to abate of their $\mathrm{Pla}$ tonism. I have ventur'd to direct this to you at the Earl of Lineoln's, tho' I dont know whether I ought to do so. I should be obliged to you if in your next that you favour me with, you would send me a List of some Books, which are both instructive and entertaining to the imagination, for I am in want of something for amusement this Winter, this being a place where I see very little company. But nothing can more enliven my solitude than the pleasure of receiving 
a Letter now and then from so good and kind a friend, whom I esteem and love very sincerely.

\section{I am}

\section{Dear Sir}

Your most faithful and obliged Serv ${ }^{t}$

Birkby Oct. 27. 1753.

T. HOOKE.

P. S. I will not omit to tell you that my Wife coloured when she read in one of $\mathrm{S}^{r}$ Harry Beaumont Letters, that a woman's beauty seldom lasts beyond five and twenty, she being almost six and twenty.

\section{No. XxxiII. \\ FROM MR. DAVID HUME.}

sik, Edinburgh Oct 15-54

THE agreeable productions, with which you have enter1 tained the Public, have long given me a desire of being known to you: But this desire has been much encreas'd by my finding you engage so warmly in protecting a Man of Merit, so helpless as Mr. Blacklocke, I hope you will indulge me in the Liberty I have taken of writing to you. I shall very willingly communicate all the particulars I know of him; tho' others, by their longer acquaintance with him, are better qualify'd for this undertaking.

The first time I had ever seen or heard of Mr. Blacklocke was about twelve years ago, when I met him in a visit to two young Ladies. They informed me of his Case as far as they cou'd in a conversation carried on in his presence. I soon found him to possess a very delicate Taste, along with a passionate Love of Learning. Dr. Stevenson had, at that time taken him under his Protection; and he was perfecting himself in the Latin Tongue. I repeated to him Mr. Pope's Elegy to the Memory of an unfortunate Lady, which I happen'd to have 
by heart: And though I be a very bad Reeiter, I saw it aflected him extremely. Ilis eyes, indeed, the great Index of the Mind, con'd express no Passion: but his whole Bodly was theren'n into Agitution: 'That Poem was equally qualified, to touch the Delicacy of his Taste, and the Tenderness of his Feelings. I left the Town a few days after; and being long absent from Scotlind, I neither saw nor hearl of him for several years. At last an acquaintanee of mine told me of him, and said that he wonld have waited on me, if his excessive Modesty had not prevented him. Ife soon appeared what I have ever since found him, a very elegant Genins, of a most affectionate grateful disposition, a molest backward temper, accompanied with that delicate Pride, which so natmrally attends Iirtue in Distress. His great Moderation and Frugality, along with the (renerosity of a few persons, particularly Dr. Stevenson and Provost Alexander, had hitherto enabled him to subsist. All his good qualities are diminished, or rather perhaps embellished by a great want of Knovledge of the World. Men of very benevolent or very malignant dispositions are apt to fall into this error: beeause they think all mankind like themselves: But I am sorry to say that the former are apt to be most egregiously mistaken.

I have asked him whether he retained any Idea of Light or colors. Ile assur'd me that there remain'd not the least traces of them. I found however, that all the Poets, even the most deseriptive ones, such as Milton and Thomson; were read by him with Pleasure. Thomson is one of his farorites. I remembered a story in Locke of a blind man, who sail that he knew very well what Scarlet was, it was like the sound of a Trumpet. I therefore ask'd him, whether he had not formed associations of that kind, and whether he did not connect color and sound together? He answered, that as he met so often both in Books and conversation, with the terms expressing colors, he had formed some false associations, which supported him when he read, wrote, or talk'd of colors : but that the associations were of the intellectual kind. The Illumination of the Sun, for Instance, he supposed to resemble the presence of a Friend; the cheerful color of 
Green, to be like an amiable sympathy, \&c. It was not altogether easy for me to understand him: though I believe, in much of our own thinking there will be found some species of association. 'Tis certian we always think in some language, viz. in that which is most familiar to us: And tis but too frequent to substitute Words instead of Ideas.

If you was acquainted with any Mystic, I fancy you wou'd think Mr. Blacklocke's Case less paradoxical. The Mystics certainly have associations by which their discourse, which seems Jargon to us, becomes intelligible to themselves. I believe they commonly substitute the Feelings of a common Amour, in the place of their heavenly sympathies: And if they be not belied the Type is very apt to engross their Hearts, and exclude the thing typify'd.

Apropos to this Passion, I once said to my friend, Mr. Blacklocke, that I was sure he did not treat Love as he did colors; he did not speak of it without feeling it. There appear'd too much reality in all his expressions to allow that to be suspected. Alas! said he, with a sigh, I could never bring my Heart to a proper Tranquillity on that head. Your Passion reply'd I, will always be better founded than ours, who have sight: We are so foolish as to allow ourselves to be captivated by exterior Beauty: Nothing but the Beauty of the Mind can affect you. Not altogether neither, said he: The sweetness of the Voice, has a mighty effect upon me: The symptoms of Youth too, which the Touch discovers have great Influence. And tho' such familiar approaches would be ill bred in others, the Girls of my acquaintance indulge me on account of my blindness, with the liberty of running over them with my hand. And I can by that means judge entirely of their shape. However, no doubt, Humor, and Temper and Sense and other Beauties of the Mind have an Influence upon me as upon others.

You may see from this conversation how difficult it is even for a blind man to be a perfect Platonic. But tho' Mr. Blacklocke never wants his Evanthe, who is the real object of his poetical addresses; I am well assur'd that all his Passions have been perfectly consistent with the purest Virtue and 
Innocence. His Life indeed has been in all respects perfectly irreprouchable.

He hat got some rudiments of Latin in his Youth, but could not easily read a Latin $\Lambda$ uthor, till he was near twenty, when Dr. Stevenson put him to a Grammar School in Edlinburgh. IIe got a lioy to lead him, whom he found very docible; and he taught him Latin. 'This Boy accompany'd him to the Greek Class in the College, and they both learned Greek. Mr. Blacklocke understands that language perfectly, and has read with a very lively pleasure all the Greek Authors of taste. Mr. William Alexander, second son to our late Provost, and present Member, was so good as to teach him French; and he is quite Master of that language. He has a very tenacious Memory and a quick Apprehension. The young Students of the College were very desirous of his company, and he reap'd the advantage of their Eyes, and they of his Instructions. He is a very good Philosopher, and in general possesses all branches of Erudition, except the Mathematical. The Lad, who first attended him having left him; he has got another Boy, whom he is beginning to instruct, and he writes me, that he is extremely pleas'd with his docility. The Boy's P'irents, who are people of substance, have put him into Mr. Blacklocke's service, chiefly on account of the virtuous and learned Edueation, which, they know, he gives his Pupils.

As you are so generous to interest yourself in this poor Man's ease, who is so much an object both of admiration and compassion, I must inform you entirely of his situation. He has gained about 100 Guineas by this last Edition of his Poems, and this is the whole stock he has in the Wrorld. He has also a Bursary, about six pounds a year. I begun a Subscription for supporting him during five years; and I made out twelve guineas a year among my aequaintance. That is a most terrible undertaking; and some unexpected refusals I met with, damp'd me, tho' they have not quite discouraged me from proceeding. We have the prospect of another Bursary of ten pounds a Year in the gift of the Ex- 
chequer; but to the shame of human Nature, we met with diffieulties. Noblemen interpose with their Valet de Chamber's or Nurse's Sons, who they think wou'd be burthens on themselves. Cou'd we ensure but thirty pounds a year to this fine Genius, and Man of Virtue, he wou'd be easy and happy. For his wants are none but those which Nature has given him ; tho' she has unhappily loaded him with more than other men.

His want of knowledge of the world, and the great delicacy of his Temper, render him unfit for managing Boys or teaching at Sehool: He wou'd retain no authority. Had it not been for this defeet, he eou'd have been made Professor of Greek in the University of Aberdeen.

Your Seheme of publishing his Poems by Subscription, I hope will turn to aeeount. I think it impossible he cou'd want, were his ease more generally known. I hope it will be so by your means. Sir George Lyttleton, who has so fine a Taste, and so much Benevolenee of 'Temper, wou'd eertainly, were the ease laid before him in a just light, lend his assistanee, or rather indeed quite overcome all diffieulties. I know not, whether you have the Happiness of that Gentleman's acquaintanee.

As you are a Lover of Letters, I shall inform you of a Pieee of News which will be agreeable to you: We may hope to see good Tragedies in the English Language. A young Man called Hume, a clergyman of this Country, diseovers a very fine Genius for that Speeies of Composition. Some Years ago, he wrote a 'Tragedy ealled Agis which some of the best Judges, sueh as the Duke of Argyle, Sir George Lyttleton, Mr. Pitt, very much approv'd of. I own that I eould perceive fine strokes in that Tragedy, I never eou'd in general bring myself to like it: The Author, I thought, had corrupted his Taste, by the Imitation of Shakspeare, whom he ought only to have admired. But the same Author has eompos'd a new 'Tragedy on a Subject of Invention; and here he appears a true Disciple of Sophocles and Racine. I hope in time he will vindicate the English Stage from the reproaeh of Barbarism. 
I shall be very glad if the employing my Name in your Aeeount of Mr. Blacklocke ean be of any service.

I am Sir with great Regard

Your very obed ${ }^{t}$ Serv $^{t}$

\section{DAVID HUME.}

P.S. Mr. Blacklocke is very docible, and glad to receive corrections. I an only afraid he is too apt to have a deference for other people's Judgement. I did not see the last Edition till it was printed; but I have sent him some objections to passages, for which he was very thankful. I also desired him to retrench some Poems entirely; such as the Ode on Fortitude, and some others, which seemed to me inferior to the rest of the colleetion. You will very mueh oblige him, if you use the same freedom. I remark'd to him some Scottieisms ; but you are better qualify'd for doing him that service. I have not seen any of his Essays; and am afraid his Prose is inferior to his Poetry. He will soon be in Town, when I shall be enabled to write you further particulars.

\section{No. XXXIV. \\ FROM MR. ROBT . HILL.}

$\operatorname{REV}^{\mathrm{d}} \cdot \mathbf{s}^{\mathrm{r}}$

QY farour of a frank from the Rev ${ }^{d}$ Mr. Coxhead I sent $B$ my Duty and thanks to you and the Hon ${ }^{\text {ble }} \mathrm{Mr}$. Herbert to Durham, if it got there before you began your Journey for London.

I made bold, $\operatorname{Rev}^{\mathrm{d}} \mathrm{S}^{\mathrm{r}}$, in that to aequaint you, that I last Summer made a critical Review of the Book of Job; which, as it contains 5 Sheets, is too large for a frank, but I have a Copy ready against the time we shall be so happy as to have a Visit of yours at $G^{t}$. Horwood. I have disposed of two Copies, one to the Rev ${ }^{d}$. Mr. Burrell, and he has sent one to 
the Rev ${ }^{d}$ Mr. Bagshaw at Bromley, Kent, which, how he approves, I must patiently expect till he comes to his Living at Addington.

I have since, by reason of a flying Report, wrote the Inclosed.* I suppose it little better, if any, than a Tale of a Tub; however, if it makes you smile at my Ignorance, I hope your goodness will pardon the attempt, and my troubling you with so trivial an affair. I have nothing to add, but my duty and thanks to you, and all my Rev and worthy Benefactors. I hope Mr. Burrell is well, I have not seen him for 5 weeks, (the Times are so hard, provisions so dear, that we are almost starved for want of Sustenance and Business, and I should quite before this, if it was not for your goodness and the rest of my worthy Benefactors, ) but I think to trouble him with a visit very shortly.

I am Rev ${ }^{d} . S^{r}$.

Your most obliged,

humble Serv ${ }^{t}$.

Bucks, Apr. 6,-57.

POB $^{\mathrm{T}}$. IIILL.

\section{No. XXXV.}

FROM THE REV. MR. JONES (OF WELLWYN).

DEAR AND ESTEEMD SIR,

Sep. 3, 1761.

I HAVE many times wondered why you never called I upon us again at 'Vellwyn. Dr. Young, I am sure, would have been glad to have seen you, and will still be so, every time you pass through this little Hamlet. He told me lately, that if he could see you, he would, or at least can, furnish you with ample materials, nor do I doubt but they will be pertinent, reluting to his late friend Mr. Richardson, the poetical prose-writer. IIe expected to have been called to Kew this summer, and if he had been summoned, I in-

* An Enquiry into the Nature of Apparitions. 
tended immediately to write to you. If her Royal Highness the Princess of Wales should still go thither, you will soon knowe, and may have an opportumity of couversing with him there. IIe semls his Respeets to You.

I have on a slip of paper noterl down what oceurred to me since I saw you, about your ancestor Neville; and also, what fell in my way to corroborate the aceount given you by Mr. Pope, relating to the ease of old $N_{o}$ ll, and the probability of his being the Person who eame to inspect the eorpse of Charles I. at Whitehall, and uttered, Cruel Necessity, \&e. I am upon the whole inclined to think, that he must have been the Man.

If I can reeover those short minutes, you shall have them on the opposite side; if not, when I shall have the pleasure ot seeing you. But God knows how long I shall continue at Welluyn: For I have still many pressing ealls to return into Bedfordshire. Please to tell me pricately in a Letter, if you can (upon occasion) reeommend a proper Successor.-I would have sent you this free postage, but am not sure that your friend $\mathrm{H} r$. Herbert is still in Purliament.

$$
\begin{aligned}
& \text { Believe me to be, Dear Sir, } \\
& \text { Your very respectful } \\
& \text { and affectionate Servant, } \\
& \text { J. JONES. }
\end{aligned}
$$

\section{No. XXXVI.}

\section{FROM LORD MELCOMBE TO DR. YOUNG.}

DEAR DR.

La Trappe, the 27th Oct. 1761.

YOU seem'd to like the Ode I sent you for your Amusement; I, now, send it you, as a Present. If you please to accept of it, and are willing that our Friendship shou'd be known, when we are gone, you will be pleas'd to 
leave this, among those of your own Papers, that may, possibly, see the Light, by a Posthumous Publication.-God send us Health, while we stay, and an easy Journey.

My dear Dr. Young,

Yours, most cordially,

MELCOMBE.

\section{LORD MELCOMBE TO HIS FRIEND, DR. YOUNG.}

Kind companion of my youth, Lov'd for Genius, Worth, and Truth, Take what Friendship can impart,

Tribute of a feeling Heart, Take the Muse's latest spark, E'er we drop into the dark.

He, who Parts, and Virtue, gave, Bade thee look beyond the grave: Genius soars, and Virtue guides, Where the Love of God presides. There's a Gulph 'twixt us and God, Let the gloomy Path be trod.

Why stand shivering on the shore? Why not boldly venture o'er? Where unerring Virtue guides, Let us brave the winds, and tides; Safe thro' Seas of Doubts, and Fears, Rides the Bark, which Virtue steers.

\section{ODE.}

Love thy Country, wish it well, Not with too intense a care, 'Tis enough, that when it fell, Thou, it's ruin, didst not share. 
2.

Envy's censure, Flattery's praise, With unmov'd Indifference, view ;

Learn to tread Life's dangerous maze, W'ith unerring Virtue's elue.

3.

Void of strong Desires, and Fear,

Life's wide Oeean trust no more ;

Strive thy little Bark to steer,

With the tide, but near the shore.

4.

Thus prepar'd, thy shorten'd sail

Shall, whene'er the winds encrease

Seizing each propitious gale,

Waft thee to the Port of Peace.

5.

Keep thy conseience from offence, And tempestuous passions, free, So, when thou art call'd from hence, Easy shall thy passage be;

6.

Easy shall thy passage be, Chearfull, thy allotted stay;

Short th' account twixt God and Thee;

Hope shall meet thee, on the way;

7.

Truth shall lead thee to the gate, Mercy's self shall let thee in; Where, it's never-changing state Full perfection shall begin. 


\section{No. XXXVII.}

\section{FROM SIR ALEX ${ }^{\mathrm{R}}$. DICK.}

DEAR SIR

Prestonfield March 6, 1762.

CIIE last year did not close, without another obliging

1 Letter from you to me, and it came just as we were eating our Christenmas Pyes-I had then just expended all my franks and our Members were all run to town, to take eare of the Nation, else you should have sooner heard, whether I was living or dearl. - Without saying more about myself, know, that my two little supporters and I, enjoy at present, God be thank'd for it! very good health : after having got over a pretty severe winter, we are just peeping about the Garden for flowers; and my Daughters have brought in some violets, which as they came into my Parlour gave us all the joyfull smell of the spring-and set us again looking for the first swallow, which, if we can catch we shall send off, with a most affectionate message to you to Oatlands, where, we dare say, it will find you,- -

- It is determin'd by my evil stars that I shall not get to town for this season to meet with you there, at Oatlands or Bifleet, these charming retirements, which naturally attract your attention; but, in the name of every thing that is good, I conjure you when you come to Durham to attend the Cathedral, (which I know is your turn this ensuing Summer,) that you proceed further north again to give us your benediction at Prestonfield; for all my people here say to one another, When shall we see again the man of God in our family? My gardener James says it always did him good to observe you take your regularwalks in the garden, every day, and suggesting to me those exeellent Improvements which he had often thought should be done himself; but could not tell the cause why, or ever so well express the reason of their being proper. At length he has overcome that woefull boxwood hedge which disgrac'd the little land before my house, on each side, and now my small plantations of trees are 
seen from top to bottom. The balefull yew with its bushy top and ugly waste, still remains to stare me in the fire; and give opportunities to James to exclaim every day against it in your name, and to walk like an execntioner with the axe in his hand to lay to the root of the tree, but I stop him, telling him it is reserved to blaze in a Bonfire, or fen de joye, upon your arrival. Depend upon it, this yew will haunt you like a ghost, in your finest walks, when you come to Durham, if you don't revisit us here.-What do you think I am busied about now? first let me tell you in shortening the way to Durham at least twenty miles, and co-operating with many others, in getting a fine bridge over the Tweed at Coldstream, and in making the ways and paths elegant, peaceable, and pleasant, elegant I say, for you know 'tis part of my seheme for public Roads in countries, that the gentlemen of property should plant at proper places, and at proper distances, noble elumps of trees of all sorts; to dignify the look of the land.

In the second place, I have the vanity to rank myself amongst the list of Inventors: for, be it known unto you, and to all men whom it may concern, that my daughter and I have found out, (for we ean do nothing without one another), a most surprizing tho' very common plant, which when I sent it in quantities to the paper mill produced 12 quire of this paper which you see here enelos'd: the plant is that green sort of filamentuous stuff, called by Limneus in Latin 'Byssus flamentis,' which you see on the ponds and lakes, in the heat of summer:- and is in immense quantities in my Loch of Dudingston. It is true; it is of a brown colour in the paper; but as you see likewise in the specimen of the dried fibrous plant, (of which my danghter made a Hat, before it was sent to the paper mill,) it is much whiter; and we imagine can be bleach'd. Our friend Mr. I Iamilton the Bookseller at Edinburgh; is greatly charm'd with this experiment; and has been very useful in making it at his paper mill. It bears writing, and notes of Musiek, without blotting in the least, and I an convine'd, had the ancients known it they would have preferr'd it to the papyrus of Egypt.-I am just 
sending, by our new member for Edinburgh, some sheets of it for Lord Bute, who is very curious in Botany, for which we made him lately an honorary fellow of our College of Physicians here. I agree with you extremly in thinking Mr. Hume's last performance a Masterpiece. He pass'd two days with me here lately, and remember'd you most sincerely with all good wishes. He made about fifteen hundred pounds, by his last two Volumes; and is really growing rich.-Dr. Robertson was t'other day put into the place of Principal, or head of the College here; which will tend greatly to forward good schemes for the Education of Youth.-

As to Mr. Blacklocke, I shall never lose sight of him, till his settlement be made complete; which is nearly like to be done.

Now My good Sir ! have not I given you a large budget! Pay me in kind, for well you can; give me hopes of seeing you here. Receive the good wishes of all your friends, particularly Lord Chief Baron and Mr. Hume, my two Daughters and I, for my littlest one is as full of prattle as you could wish.

I conclude in wishing every good thing to attend you and your Noble friend at Oatlands. May you and he long live to enjoy those fine rural scenes; and may I live to see you often, at least once in two years, under my roof here.

I am yours, in the sincere and

best manner,

ALEXANDER DICK.

P.S. Are you not prodigiously astonished with Fingal, but of that amazing piece, it is impossible to say enough here.

P.S. Dear Sir my loon is well at Straburgh; and I dont hear he comes over yet, by his Letters to me. 


\section{No. XXXVIII.}

\section{FROM SIR ALEX ${ }^{R}$. DICK.}

June, 15.

1 VERY possible degree of thanks from the hearts of most kind, and hearty exelamation, upon receiving the news of our new system, is return'd, from us all : and in particular from me, to the best of friends; to the man of God whose blessings we receive, as beatitudes which we feel.

Now my Dear $S^{r}$ I dare say you would wonder you had not receiv'd a letter from me sooner as you gave me a warm recommendation in favour of your worthy friend Mr. Ridley; whom, the moment I got your letter of May the third, and read his proposals, I became most ambitious to serve. And it was for these reasons alongst with another, which I believe will affect you a little, it has not been in my power to write you what $I$ have done in that matter, till this very day, the first of June. My Daughter and I, are sitting in your long room, which I hope you will soon return to ; I dictating, and she writing you, this dispatch. You must know that it was only yesterday I left my bed, which I had kept for eight days from a relapse of the Epidemical fever, by going too soon out to a publick meeting on the county Roads; after which it attacked me with triple force in the shape of a pleuretie fever; which requir'd powerfull bleedings, \&c. and before I got well, which I thank Almighty God, I now am, reduc'd me to my marrow-bones, and to be ready to give you the oblations of my first fruits, which I date from your chapel here. This I know would affect you, and my daughter is very well pleased that is over, and as she is very much interested in Mr. Ridley, bids me next proceed to that business. In short, I early sent before the general Assembly met, for Mr. Kincaid his Majestys printer at Edinburgh to come and dine with me, as he is the most considerable man of that profession, in the Bookselling way, that I knew; and 
who, with the large fortune he has made, has always shown himself the humane good man; as I knew he had sentiments, I let him into the state of Mr. Ridleys numerous family; He said he knew the gentleman's excellent good character; both as a writer, and a man, and lid not doubt the general success of his work; but he mention'd freely that the bulk of the clergy of this country buy few books, except what they have absolute necessity for ; however, he said, that uas nothing: that he should not be discouraged, but would upon every occasion promote the subscription. He said if some more of the proposals uere sent doun and left at his shop; he would be glad to receive them under his trust; I told him the single one I harl, I would only part with to him to show them; but that I wou'd write you what he was pleas'd to tell me in this matter. I desire the favour of you to mark me for this Subscription; and be so good as pay Mr. Ridley the whole of it at once; which I shall pay you back, either to your order, or at meeting in September, as you shall think proper. So far $I$ had proceeded in what $I$ had wrote the first day of June; but thinking it necessary to send likewise to Mr. Hamilton bookseller, whom I knew you had oblig'd when you were here last, and whom I suspected you had not writ to, upon this occasion. I therefore sent for him, while I continued confined to my chamber; and he not coming out till yesterday, you have my Letter of two dates, as this is the sixth of June; (dated from your chapel, which my Daughter calls the chapel of Ease, as I enjoy great tranquillity in it;) and tho' still in my night gown, am recovering strength daily, and receive company every afternoon at tea. What with good nursing from a most excellent wife, and from my daughters musick, with which she entertains me; and little Annie's prattling, with which she diverts me ; and from some works that are going on in the garden, particularly a new, neat little house, in the very spot where you fixd it; and some road work on the north side of the house, to take away all the earth, that lay heavy upon the foundations of the buildings, to fill up other hollows with which I hope you will be pleased, when you come here: I have a considerable 
cirele of oecupation from my winlows. Also the preparing considerable enantities of the Byssus (at small specimen of which I inclose) for paper, mueh whiter than last year's, I have found out a considerable use it will be to surgeons to dress wounds and sores with, instead of sharpe, or scrilpid linen, for which they pay five shillings a pound.

Mr. Hemilton assurel me that if you think proper to order any of your booksellers at Durbam, who hats subseription papers and proposals, to forward them to Mlr. Ilmilton, he will do his utmost to serve Mr. Ridley, or any other of your friends.-I have heard from Dr. Armstrong firom Osnaburg, who is very well, but longing for a petce, and to be out of the way of greasy sauces and bat old hock: he promises to bring some of the olive branches with him to decorate my house, and stay tro or three months with me, having half a guinea a day during his life; which is more than he ever expected, he says; and more than he needs. David Hume is well, as is $\mathrm{D}^{\mathrm{r}}$ Robertson; and they will be both glad to see you when you come.-Hou do you like Fingul, that ustonishing fragment? have you look'd into the Criticism by Lord Kaims? his Lordship wrote a great part of it in your chapel, when he was my guest, so that you are so far eoncern'd; and he and I would be glan of your opinion of these three volumes. If you have not read them you shatl read them here: and you shall see my Lord, either in your going or coming from Durham: for the new britge at Coldstreum proceeds, to make you nigher us by near thirty miles, and an easy new road.-1Iy Wife, my Danghter, aud little one, all in one society wish you well and soon here; my late fever disables me from visiting you this summer, as I intended.I am with all truth and affection

$$
D^{r} S^{r} \text {. }
$$

\section{Yours}

\section{ALEX $^{\mathrm{R}}$ DICK.}

P. S. I have sent a sample of the Byssus, crop $1762 \mathrm{w}^{\text {ch }}$ will make the paper much whiter than last. 


\section{No. XXXIX. \\ FROM SIR ALEX ${ }^{R}$. DICK.}

DEAR $\mathbf{s}^{\mathrm{r}}$.

Prestonfield, Sep ${ }^{\text {tr. }}$ 4, 1762.

TOUR letter from Sedgefield came to my hand by last 1 post, the punctuality of your motions towards the North, and the good health, which I presume Heaven blesses yon with, to accomplish those excellent ends you always have in view, gives me, and all my little family, infinite satisfaction, especially, as you promise to be our guest by the first of October.

It is pity you had not been here earlier in this good season we have had profusion of perfectly ripe apricots, peaches, plumbs, and figs, more so than in most years; but now I see this day such fine showers falling after so long and immense drowth, that I promise you a hearty welcome, to our genial roof, to your quiet bed-chamber, and your long room, to your little Library which happily has, John Major's history of Britain, the book you want, and I think I may promise you welcome (from these showers) to a profusion of new verdure, which I see rising instantaneously, and I foresee will paint the amenity (which you lik'd so much in my place), with beautifull various tints, among the chequer'd shade of my fields, when the fall of the leaf next October approaches. I expect, after the first Lightening, a deluge of fine mushrooms from my sheep walks and lands; this I have learned from observation, since I saw you; and I happily found it confirmed, when I was reading the fourth Book of Plutarch's Symposiacs, to which I refer you, as a very singular and curious passage in antiquity about Lightening. This wonderful vegetable raised in a night, (I mean those of the best kind), by the power of lightening penetrating into the dry and warm surface of the earth, where pasture is; when a drissling show'r, which we know to be the conductor of this fire, suddenly operates upon the seed or spawn of the mushroom; really prepares for you, every morning a dish of 
(pardon me!) Celestial food! ambrosia, or whatever you please to eall it.

I am raving about this; for nothing agrees so well with myself (and I ean recommend it to all my friends, who are marching tewards, or have past their climacteric), as a small dish of these every morning before tea, prepared by my man James, toasting them well before the fire, and basting them with a little new-ehurn'd butter, and dashing them with some pepper and salt, very finely pounded. The nerves of the whole man feels the immediate benefit of this atherial dish, if taken fasting before tea, and greatly improves the relish for fine tea, and wonderfully prevents the effeet of shakings and palpitations, which many people find from a large use of that admirable liquid.

Dont mistake me, in thinking that all Funguses are good; many of them proceed from impure fire, and those we must avoid-and indeed they are insipid or of a noisome smell, tho' there are few proofs, if any, of their being poisonous; they commonly arise in the field from the putrefaetion or dung of animals, or from rotten roots of old trees, and that impure fire, is contain'd in a phosphorous, which you know makes rotten wood shine in the dark.

I have a thousand new things to tell you. My Nieces the Miss Keiths, are here, and will be of our eircle, when you come; we have had every now and then, letters from their papa, the Embassador in Russia ; one lately brought me inelos'd a letter from the poor late Emperor's physician, Dr. Mounsey where he said, the Emperor had made ehoice of a few agreeable friends, and Mr. Keith was one, to pass a fortnight on a party of pleasure, at the eharming country palace of Orangebaumb, but alas! in three days all his grandeur and joys were at an end! Heaven send us, as you wish peace, and Dr. Armstrong and I add our friend Keith back to us from that detestable court. Dr. Mounsey is on his way to Edinburgh, after 30 years absence in Russia. He resign'd his office since my letter from him. All blessings to Dr. Lowth and you.

\section{Yours,}

ALEXANDER DICK. 


\section{No. XL.}

\section{FROM SIR ALEXR. DICK.}

DEAR SIR,

Prestonfield, August 25,1765.

C $\mathrm{N}$ this very $25^{\text {th }}$ day of last month you wrote me from Byfleet a most affectionate congratulatory letter on the success I had with my four elildren after their being inoculated with the small pox. Indeed it was an Event to me of the most interesting nature, and Heavens blessings to me (and I can not help, saying to you as being one of our best friends, ) on that occasion has been most powerfully and happily bestow'd, for which letter I return you my own and my family's, most hearty thanks. Every good thing has flow'd upon us since as their healths are perfectly good, and your prayers are always powerfull.

Your agreable jaunt to Clumbe park must have been perfeetly to your taste, as I think I see how you wou'd eye each part, and then the whole, and catch now and then some new beauties, which had escaped my Lord or some of his ingenious friends with you. The short time I stay'd at Nottingham, when last there in the year 1760 , I was much pleas'd with the general look of the comntry, but had not time to examine the particulars which gave rise to the amenity I discovered.

I give over hopes of ever seeing amy thing of Dr. Armstrong but his Ghost! He tantalized me with hopes of a visit, but Lord Granby wafted him away anotler way, so all I said, was pox take my Lord Granby! for which my nephew the Colonel, gave me a severe rebuke; as, says he, we dont know how soon, upon this change of the ministry, we may have a new war with France, in which case his health is precious. How cou'd it happen that the Dr. and you play'd so exactly Bo peep? He sent me a very good letter, with a Dutch physician, who call'd here last week to see the progress of physich here, which indeed is something surprizing.

Apropos your anxiety about your wonderfull ingenious friend Blacklock is most natural. I call several times to see 
him, and finl both himself and his worthy help-mute chearfull and happy in their new habitation, and lately as I conld not get to see them my self, I sent my Wife, since I got your Letter, to make more particular enquiries, and she reports to me that they hare got a certainty of 7 Baurders, und have place only fin one more, which I hope the winter camnot fail to pronluce to them: ut present in the honse only 3. The rent of the house is high, but it is eommodions, and all the furniture new, and kept very neat. Your intended hummity to them will, I dare say, be very seasonable, and I presume will be the last they will need to set them well on their feet. I expeet they will make me another visit before the pleasant harvest weather we now have is over, as I intended to regale him with the sight of a copy of a Letter I have just now got from a relation of mine, brother to $\mathrm{Mr}$. Archbald Gibson, Merchant in Dantzic; it is wrote in English, by the present King Stanislaus, of Poland, to that gentleman, who, it seems, had the trust of remitting his money and other concerns, which carefully executed for him uhen he had his first education in England; and with whom at the siege of Dantzick, his father, old Conut Poniatowski, stay'd and had much aid and assistance from him. As it will please Mr. Blacklock much, I am sure it will please you. The copy follows : N. B. Mr. Gibson had sent a Congrutulatory Letter to the King on his Coronetion.

IVursuw, the 19 Septr. 1764.

"I have received your most friendly Letter of the 12 th with " a heart I dare say correspondent to the goodness and open"ness of yours. I remember you perfeetly well and can "assure you Sir that I preserve a particular liking to those " whom my first infant looks have learned me to cull friends " and familiars to my parents. Inheritance is a saered Title; "I have a claim to you Sir, which l'll never let fall. May "Ilearenly goodness pour his Bountys upon you. May the "Lord be pleased to bestow me often and largely opportu" nities and means to show by the most convineing proofs to 
"you, to your family, and to the egregious British nation, " how dearly and high I love and esteem you and them. "This is, and will be the everlasting wish of your

most affectioned

(Signed) STANISLAUS AUGUSTUS, KING.

"P.S. Long disuse has (I am afraid) spoil'd my English " language, but I hope thro' all the philological faults, you "will reed the truth of my affections."

If this friendly Letter from a crowned head to his friend can entertain your excellent patron, Lord Lincoln, or your worthy brother prebend, Dr. Lowth, you are at liberty to send them or any other you like, a Copy. Mr. Keith says, the present King of Poland, the author of it, was his particular acquaintance when a subject, and was then worthy of the highest estimation, both for ability and goodness of heart. Happy the people of Poland, had they but a good constitution of government!

I shall long for next July, which you mention; may Heaven bring us both together at Durham in good health. My Seeretary is at the Earl of Balcarass's, in Fife, but is perfectly well, and long'd, by her last, to hear of you. My wife, and all Mr. Keith's family, and I, send you every good wish.

Yours always,

most affectionately,

ALEXANDER DICK. 


\section{No. XLI.}

\section{FROM DR. JOSEPII WARTON.}

DEAR SIR,

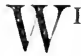

IIILST I was searching our College Register in eompliance with your request, we reeeived that dreadful Blow of our poor Warden's death; with whieh I must own to you I was so struck and confounded, that it put all other thoughts quite out of my heal. 'This was followed by some events very interesting to Us here; especially one, that was well worth attending to, which was the near prospect of having Dr. Lowth for our Warden. This he will explain to you. I mention these eireumstances as having engrossed my attention, and having compelled me to do a thing which I entreat you to pardon, the negleeting to answer your very kind letter. You may depend on Master Massingberds meeting with all the Tenderness and Care, it is in my power to bestow on Him; not only for his own sake, who appears by your aceount so well to deserve countenance and encouragement, but most certainly on aceount also of your warm reeommendation. I have ever made it my business particularly to attend to Lads of that temper and turn, of which you deseribe him to be.

As soon as I ean again get access to our Registers I shall proceed in my seareh about the entranees you mention : and in the mean time inform you, that Dr. Burton assures me, the whole of Necds's Story* was a Trick, coneerted to im-

* Note on Dr. Warton's letter No. 41. from Mr. Spence's papers.

Dr. Burton thinks Needs' story an idle one. He was a loose, idle boy. His first account was, that $K$. Charles II. came to him with a pipe in his mouth, whilst he was at the Foricas, and told him, that the old chaplain, and the bishop of Winchester would die that year. He went afterwards on Midsummer eve into the chapel porch, and there fell asleep. Whilst he was there, Charles Coker pull'd off' his gown and waistcoat, and walked by him in his shirt to frighten him. 'This waked him, and he said, he should die, because be found he had been asleep; for it was believed, 
pose on Dr. Fletcher. Needs was known to be drunk that night, and the Story was contrived to alarm his Masters with something Extraordinary, and by that means, turn off their attention to his fault. His character was that of a dissolute drunken boy; and Dr. Burton says, the very first Punch he ever tasted was of Needs's making in Sixth Chamber.-How ever the exact time in which he foretold He should die was in truth an extraordinary affair. He sat next to Burton (the Physician afterwards) in the Chapel when he sent for leave to go out-told Him then in the Chapel that he should die in a few Days, and that night named the precise Day, which happened accordingly.

Mr. Lowth desires me to inclose a packet to you-I wish our exeellent friend, Mr. Pitt's pieces had appeared in better Company, and in a more honourable Collection. Mr. Lowth tells me you had thoughts of spending a few Days with Him at Winchester; which would have given much pleasure to many persons here, but to none more, than,

\section{Dear Sir,}

to your obliged and affectionate humble Servant

Winchester, Commoners College, Jan. 15, 1764 .

JOS. WARTON.

P. S. Mr. Lowth has just sent me word that his packet is not ready.

that whoever on Midsummer-eve should fall asleep in the churchporch, would die that year. Some time afterwards he was taken ill at chapel; and told Simon Burton, who sat next to him, that he shonld die by that day sen-night, or within about that time. He had a fever, and was delirious; but afterwards came to himself, and asked what day of the week it was; the nurse told him Friday, tho' it was Wednesday, on purpose to deceive him. He said, it could not be Friday, fur that he was sure he should die on Thursday, as he really did. 


\title{
No. XLII.
}

FROM MR. SPENCE TO DR. WARTON.

\author{
DLAR SIR,
}

Jany $19^{\mathrm{th}}, 1765$.

I

IIAVE had the pleasure of passing these Christmas IIolytlays with my dear little friend Charles Massingberd; and am hall' sorry to part with him, tho' he is to bring this to you. lle has talked so much of your goodness to him, that he has often given me a great deal of pleasure ; and indeed I never doubted of his doing justice to my recommendation, when he first waited on you. I rejoice to see in him all his usual good nature which he then hat, together with the polish and improvements acquired sinee he has been with you, he has been the delight of the whole family, and we shall all miss him exceedingly.

I have been very busy for some time in preparing poor Mr. Holdsworth's notes and observations on Virgil, for the press; and they would have been printed in the summer that is coming on, had not I fortunately been promised a new set of his papers, from a relation of his at Dartmonth; which I hope to receive when I go from hence to London; where if you should be so good as to favour me with a line or two, they would find me, about a month's hence, at Lord Lincoln's in the Exchequer.

Will you give me leave to remind you of the queries I formerly beg'd answers to, and to repeat me in a postseript. I suppose most of them may be answered by once tumbling over the College Register, and if any are diffieult, I beg they may be looked on as not askt. I am ever,

Dear Sir,

Your obliged and

affectionate humble servant,

J. SPENCE. 
In what year, and on what day did Dr. Mews, Bishop of Winchester, die?

On what day or about what time did Mr. Carman, Chaplain of Winchester College, die?

What the ages of Burton Senior, Coke Senior, Norden, Rymes, and Edmunds, on the College Books?

What the times of Edward Young, Edward Holdsworth, and William Harrison's entrance into the College, and leaving it? 


\section{DOBSON'S VERSION OF POPE.}

II. Irixg found among Mr. Spenee's papers a specimen of the trans lation of the Essay on Man into Latin verse by Dobson, mentioned at p. 135. I have subjoined it, to gratify the lover of modern Latin verse.- - id.

Dobson had acyuired great reputation by his translation of Prior's Nolomon, the first book of which he finished when he was a seholar at Winchester College. Ie had not at that time, as he told me, (for I knew him well), read Iucretius, which would have riven a richness and force to his verses; the chief fault of which was a monotony, and want of variety of Virgilian verses. Mr. Pope wished him to translate the Essay on Man; which be began to do, but relinquished on account of the impossibility of imitating its brevity in another language.-Warton. Boules's Pope, v. 274.

Dobson spent some time at Pope's Villa while he was engaged on the Essay on Man, and when Dr. Johnson asked him what learning he found Pope to possess, he answered, more than $I \mathrm{es}$. pected.-Life of Pope, 255 .

\section{ESSAY ON MAN.}

\section{Fisistle 1. v. 17, \&c.}

" Say first of God above, or Man below."

D IC age, sive hominem Ratio studiosa sequatur, Sive Deum exploret; sua quo vestigia filo Dux incerta animi, rerum extra cognita, ducet? Hoc solùm angusto terrestris limite vita Spectandum se prabet homo; nil panditur ultra. Numine diffuso quanquam Deus omne quod usquam est Impleat, at nobis nostro tantùm orbe sequendus. Quicunque immensum Spatii penetraverit æquor, Utque unum in corpus coeuntes Orbibus Orbes ! Miscentur, seriem ut series premit ordine certo, Observans, Soles alios aliosque Planetas 
Et varia in variis $A$ nimalia viderit astris ; Hlle idem expediet, cur nos hoc corpore Numen Inclusit. Tù verò hujusce ligamina molis, Foderaque inter se, certâ coeuntia lege.

Continuosque gradus penetrasti mente sagaci? Tume hæc? Particulæne datur comprendere Totum?

Vinclum ingens, stabili quod fœedere cogit in unam Omnia conglomerans molem, servatque coacta Anne immensa Dei manus an tua dextera fulcit?

Vanæ mentis Homo! Quæris cur corpore clausus Exiguo, cacusque adeo fragilisque laboras? Quin age, si potes, abstrusam magis inspice causam, Cur neque debilior, neque cæcior, et magis arctis Corporis inclusus spatiis; Terramque parentem Consule, procero cur vertice Quercus in auras Fortior assurgit, quàm quæ latet herbula opacis Sub ramis : Cœli lucentes consule campos Qua stipant Jovis astra latus Jove cur minus ardent.

Si Series rerum sit perfectissima summi Artificis quam magna Dei Sapientia fingit, Quæ membris aptè coeuntibus arcta cohæret, Omnia dum sensim certo discrimine surgunt; Inde in continuâ Vitá Sensûsque catenâ Aut hic, aut illic, Hominem constare necesse est : Et solum hoc restat, verborum ambage relictâ, Quarendum Statione illi male congrua detur?

\section{ESSAY ON MAN.}

Epistle II. v. 53, et seq.

"Two principles in human nature reign."

VT IS gemina humano regnat sub Pectore; Calcar Cuique sui dat Amor; Ratioque adjungit habenas. Neutra tamen per se spectanda est; utraque certum Munus habet: ciet una, attemperat altera motus : 


\section{DOBSON'S TERSION OF POPE. 37}

Utque suas pejus meliùsve obit ntraque partes, line Bona proveniunt, fons ducitur inde Malorum.

Urget Amor nostri stimulus, movet intus agitgue lgnem anima; Ratio stabili regit aequa bilance: Ni ciat illa, IIominem Socordia lenta teneret;

Ni regat hae, trilheret necquicquam caca Voluntas. Aut Planta in morem terrâ gaudentis eâdem, 'Tintim aleretur iners, fotum ederet, atque periret; Aut rueret sine more, exlex ut in athere flamma, Seque aliosque vago disperderet inscius igne.

Vim motrieem Anime valido natura vigore Aptavit, stimulare hominem atque accendere natam: Pacis amans tacitè sedet Arbitra, Factaque secm Perpendens, monitis regit, imperioque coereet. Altera, ut objectum propius, violentior ardet; Dum vigiles oculorum acies procul altera tendit: Illa bono capitur præsenti ; hæc provida seros Prospicit eventus longèque futura tuetur.

Cingimur illecebris, paucis defendimur armis; Consilioque valet quamquàm Arbitra; robore prestat Vivida vis anima: qua ne exerat acriùs ignem Ingenitum, cultu assiduo et Ratione Magistrì Utendum : longo Experientia crescet ab usu, Quæ Rationem armet, Nostrâ compescat Amorem.

Ilos rixæ studiosa paret discindere amicos Turba Sophistarum : efficiatque ut Gratia pugnet Virtuti, ut Sensû Ratio; temeraria lites Dum serit insanas, artemque ostentat inanem : Quos, uli sxpe grave exercent de nomine bellum, Aut nihil, aut omnes unà sentire videbis. At Ratio, Nostrumque in nos amor insitus, unum Affectant finem, impulsuque sequuntur eodem Blanda voluptatis, fugiuntque Doloris amara: Sed Flores hic dente avido vorat; altera cautis Mella bibit labris, neque germina mollia ladit. Summam animi pacem, verè intellecta, Voluptas Parturit ; infundos aliter fert ipsa Doloris. Iuic Nostrûm ingenito servire videntur amori 
Pectoris affectus : aut verum, aut æmula veri Unbra boni quemque urget: at omnia participare Cum nequeunt, Ratioque monet nos quarere nostra; Affectus, qui se solùm et sua eommoda curant, Dummodo Fas servent, Rationis castra sequuntur; Qui sese diffundere amant generosius, auetum Nobilitant genus, et Virtutum nomina ducunt. 


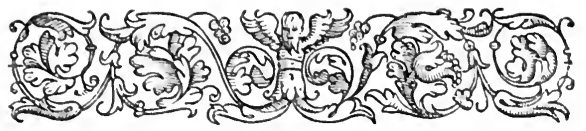

\section{INDEX TO TIIE LETTERS.}

No.

I. Frow Mn. l'ope, requesting Mr. Spence to return his letters, and containing general expressions of regard

II. From Mr. Cinnstopuen Pitr, enclosing a Prologue .

III. From Mr. Roвkn Downes.-Observations on the prevalence of Free-thinking in the University of Oxford ; -attributed to the predominance of Mathematical Studies

IV. From Dr. Evwarp Youxg.-Introducing Thomson the Poet to Mr. Spence . . . . . . . . 293 29.1

296 298

$\checkmark$. From stephex Duck.-Account of an interview between him and Curll . . . . . . . . . Ibid.

VI. From Mr. A. Sмrт.-Account of a Riot in London, occasioned by a drunken frolic of Lord Middlesex and some friends, on the 30 th of January . . . . . 300

VII. From Tue SAme.-On the same subject . . . . 301

VIII. From Lon Mindersex.-On the same subject . . . 303

IX. From Mr. Spence to un Mother: from Turin, Account of the representation of a Mystery, entitled The Damned Soul. This representation is also mentioned by Gray in one of his Letters . . . . . .

X. From The Same to the Same,-Humorous account of an Italian Surgeon . . . . . . . . . 308

XI. From The Sine to tue SAne.-Account of Andrey, a Frenchman, one of the Adepts or Alchemical Impostors .

XII. From Horace Walpole.-Professions of friendshipand enclosing Verses by Pope . . . . . . . 313

XIII. From Tue Earl of Orford (Sir R. Walpole), to Col. Chunchul. - Invitation to country quiet and contentment . . . . . . . . . . . 
No.

XIV. From Mr. W. Carr to Mr. Spexce.-Account of the revival of a drowned man at St. Neots . .

XV. From Mr. N. Inerbert,-On the rescuscitation of drowned persons . . . . . . . . . . .

Xi1. From The SAmE.-Demosthenes' cure for stammering-Essayed.-Origin of the term Quack . .

XV1I. From Tie Rev. Gloster Ridlex,-Dr. Lowth's Poem the Judgment of Hercules.-The Samothracian Mysteries.-The Cabiri . . . . .

XVIII. From The SAne, - with part of his Poem in Imitation of Spenser, sent as a fragment of an old MS.

XIX. From TuE S.unE.-Reply to Observations on the Imitation of Spenser . . . . . . . .

XX. From Mr. Edward Rolle. Superstitious story of deaths foretold by passing through a church porch

XXI. From Mr. Whenler.-Account of Mr. Keirl, The Ian of Ross . . . . . . . . . . .

XXII. From Mr. Robert Dodsley, Observations on Re-

tirement . . . . . . . . . . 331

XXIII. From The Same.-Enclosing a Love Song . . .

XXI. From Mr. Robert Wood,-Account of his intended tour in Greece-soliciting hints from Mr. Spence

XXY. From Dr. Roвert Lowr h, from Turin.-Account of the death of Count Richa . . . . . . .

XXVI. From Tin SAlE.-Princess of Carignan.-Sig. Paderni.-Preparations for publishing the Antiquities of Herculaneum.-Sig. P.'s opinion of the Polymetis . . . . . . . . . . .

XXVII. From Stephex Duck.-Appointed chaplain to a regiment of dragoons, his verses to his censors on that occasion . . . . . . . . . .

XXIIII. From THE SAuE.-Further particulars of the Man of Ross . . . . . . . . . . . 310

XXIX. From IIonace Walpole.-Translation of Illam quicquid agit, from Tibullus.-Inscription on a neglected column at Florence . . . . .

XXX. From Mr. Edward Rolle.-Gipsy prediction.Addition to salary of the Poetry Professor at Oxford.-Increase of students at New College . 
xo.

XXXI. From Tur Same, from Mayence-Passage of the

Alps. - Comforts of travelling in Germany.The Tyrol.-Mount Brenner.-Of the khine.

-Its junction with the Moselle . . . . . 31.i

XXXII. From Mn. Hoon : J J - Euclosing verses to Mr. spence . . . . . . . . . . . 349

XXXIIt. From Divid Hest.-Iccount of Mr. Blacklock, s.. . . . . . . . . . . . 3.0

XXXIV. From . Ми, Ronen llit..-Thank for Mr. Npence's benevolence, and enclosing an knquiry into

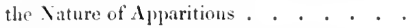

XXXV. From Mn. Joxps-luvitation to Welwyn from

1)r. Young, and promise of particulars relating to the Life of Richardson . . . . .

AXXit. From Lord Melcone to Dr. Yousg-Enclosing Verses to him, and an Ode . . . . 357

XXXViI. From sir A Lexavder Dick.-Return of spring. -Improvement at P'restonfield and its Environs. - Paper made from an aquatic plant.Iir. Hume.-Dr. Robertson, dic. . . . . 360

IXIVIII. From The SAuE.-llis Illuess and Recovery.Dr. Armstrong._Fingal._Lord Kaim's Elements of Criticism . . . . . . . . 363

XXXIX. From Tur sims-Cause of the spontaneous growtin of Mushrooms . . . . . . . . 366

XL. From Tue SAмe,-Dr. Armstrong.-Mr. Blacklock.-Enclosing a copy of a Letter from Stanislaus King of Polaud . . . . . . . . 368

XLI. From Dr. Josepil Wirtos.-Death of the Warden of Winchester.-Singular Story of the prediction of Need's death by limself . . . 371

Xlil. Mr. Spence to Dr. Wanton.-Miscellaneous . 373 XLIII. Specimens of Dobson's Latin Version of Pope's Essizy on Mlan. . . . . . . . . . 375 



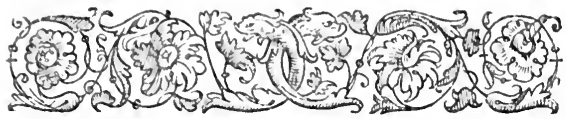

\section{INDEX TO THE ANECDOTES.}

I DDIsox, 2 note, $7,8,35,36,37$, $38,41,51,70,86$ note, 101, 110 , $112,113,114,129,126,127$, $132,139,141,145,148,119$, $151,153,175,176,178,194$, $199,216,229,235$ note, 239 , $247,254,257,258,261,261$, $266,267$.

Adrian II, Pope, 37.

- Emperor, 183 ; tomb of, 66 ; bust of, 172 .

Eneas, 95, 96.

Agriculture, 97 .

Alberoni, Cardinal, 24, 43, 100. Albinus, $17 \%$.

Alcander, 209.

Aldrich, Dr. Henry, 212.

Alessandria, 167.

Alexander the (ireat, 157.

Alexandria, 71 .

Algardi's Attila, 71.

Allen, Mr. 185, 271, 27:3.

Alps, the, 63.

Altars, three, in the Capitoline Gallerv, 181.

Amalthei, the, 50 .

Ancaster, Duchess of, 41 note.

Aucona, Arch of, 97 .

Anderson, Dr. 104 note.

Andreini, 132.

Aune, Queen, 55, 115 note, 198. Antinous, 70, 255.

Antiques dug up at Rome, 72.

Antonine, Temple of, 70 .

Antoninus Pius, Meda!s of, 173.
Apollo slaying Marsyas, Gem of, $170,17 \%$.

Arbuthnot, $D r .8,109,126,152$, $177,250$.

- Miss, 238.

$\longrightarrow$, Mrs. Anne, 213, 278.

- Robin, 237, 238.

Architecture, 10, 96.

Arts, 9, 10, 65.

Argensola, 83 note.

Argyle, Duke of, 120 .

Ariosto, 19, 75, 76, 82, 83 note, $90,91,211,259$.

Aristotle, $5 \%$.

Arretino, Statue of, 170.

Arria and Patus, Group of, 68.

Ascham, 133.

Atterbury, Bishop, 8, 55, 106, 117, 118 note, 133, 149, 209, 23.5 note.

Atwell, 253.

Augustus, 8 .

- Mausoleum of, 97.

- Arch of, 69.

Aulus Gellius, 163.

Aurelius Marcus, 69, 207.

Avignon, 6, 32.

13accuus, 85, 182.

- Statues of, 172,173 .

-, Mysteries of, 234 .

Bacon, Lord, 11, 128, 174, 212, 235 note, 253.

Bagnel, 17. 


\section{INDES TO THE ANECDOTES.}

Baillardeau, Mr. 251.

Baillies, Mrs. 158 note.

Ballard Papers, 252 note.

Balzac, 13, 133.

Bandinelli, 171 note.

Banister, 146, 196, 214.

Barber, Alderman, 233.

Barberini, Cardinal, 80.

Barclay, 144, 202 .

Barnes, 216.

Barrow, 1saac, 235 note, 280.

Bartoli, Isaac, 184.

Basnage, 261.

Bassi, Antonia Maria, 83.

Bath, 115, 123.

Bathurst, Lord, 9, 132, 191 note, 258.

- Ralph, 251 note, 254 .

Bayle, Pierre, 162, 203.

Beaufort, Duke of, 69 .

Beaumont, Sir John, 17.

Beggars' Opera, origin of, 120.

Behmen, Jacob, 920.

Bell, John, 110.

Bembo, 17, 50, 75, 76, 165, 259.

Benedict XIII, 30, 60.

$-\mathrm{XIV}, 168$.

Benevento, Arch at, 97.

Benson, Mr. 135, 155.

Bentivoglio, 259 .

Berettoni, 69 note.

Berkley, Dean, 107, 190 note; joem by, 191 .

$\longrightarrow$, Earl of, 256 .

Bermudas, 191.

Berni, $76,77,90$.

Bernini, 65, 71, 260 .

Berwick, Duke of, 156.

Bethel, Mr. 103 .

Betterton, Thomas, 4, 7, 19, 129, 147, 149, 208, 209, 222, 255.

Bianchi, 170, 171, 17\%.

Bianchini, :8, 4\%.

lible, how it should be read, 53 . Bignon, Abbé, 140.

Blacklock, Mr. 19 note.

Blackmore, Sir 'T homas, 211.

Blackstone, 33.

Blandford, Marquis of, 260 .
Blenheim, Inscription at, 127.

Blois, 139.

Blount, Mr. 2, 248, 289.

—, Mrs. 160, 197, 202, 271, 272,273 note, 280.

- Martha, 115 note.

Boccaccio, 169, 259.

Boiardo, 76,90 .

Boileau, 7, 46, 50, 99, 278.

- Abbé, 141.

Bolingbroke, Lord, 11, 12, 3.5, $40,50,106,108,110,115$, 127, 128, 134, 159, 176, 199, 201, 215, 223, 295, 226 note, y28, 235 note, $238,239,240$, $242,243,244,257,258,268$ note, $269,272,274,281,282$.

Bologna, $16 \tau$.

Bolton, Duke of, 215.

Booth, Barton, 35 .

Boscan, 83 note.

Bossu, 146.

Bossuet, 21, 22.

Boulogne, 237.

Bourdaloue, Pìre, 30.

Bowles, Rev. W. L. 176 note, 177 note, 196 note, 274 note.

Bracegirdle, Mrs. 286.

Brandreth, Mr. 250.

Brett, Colonel, 34, 148, 270.

Brettoni, 68.

Bristol, 115 note.

Broome, William, 205, 248.

Brown, Sir George, 147, 118.

$\longrightarrow, M r \cdot 127,154$.

Bruschius, 203.

brutus the elder, Bust of, 17\%.

Buchanan, George, 51 .

Buckingham, George Villiers, Duke of , 3, 4, 47, 48, 124.

- Sheftield, Duke of, 177, 195, $215,291$.

—- Duchess of, 277 .

- House, 177 .

Budgell, E. 110, 122 note, 148, 194.

Bull, Bishop, 277.

Bumper, origin of the word, 79.

Buonaparte, 158 note. 
Buonarotti, Senator, 82.

- Michael Angelo, 51, 65, 71,80 .

Burgundy, Dnke of, 21.

Burlington, Lord, 80, 158.

Burnet, Bishop, 11 note, 11\%, 175 note, 250 .

Burton, $D_{r}$. 2 dĩ .

Butler, Samuel, $13,15 \pi, 235$ note, 250.

Button's Coffice Ilouse, 110, 112 note, $149,199,216$.

Buxtorf, 78.

Byther, 78 .

Canogax, General, 116.

- - Lord, 117, 118, 123.

Caen, 57, 62.

Ciesar, Julius, 61, 66, 108, 141, 239.

- Bust of, 172.

Calphurnius, 93 note.

Cambridge, University of, 4 note.

Camlen, 4 note.

Cape Bon, 94.

Caracalli, Giem of, 172,

-, Medals of, 173.

- Baths of, 63,70 .

Carew, Thomas, 17.

Carey, Ilarry, 148.

Caroline, Queen, 56 note, 249 .

Carteret, Lord, 190 note.

Carthage, 94.

Cartwright, William, 17, 109.

Caryl, Mr. 148.

Cassini, 28.

Castillejo, 83 note.

Catiline, 69.

Cato, 111, 254, 268.

Catrou, 260 .

Cavalier, 42.

Celamar, Prince of, 33.

Centaur, Statue of, 182.

Cervantes, $17 \overline{0}, 189$ note.

Cervetere, 95.

Chandos, Duke of, 109.

Chapelaine, 17.

Chapman, 131.

Charles 1, 216.

$-11,13,129,161,193,280$.
Charles V, 37, 82.

(harlett, 1)r. A1. 251 note, $25 \%$ note.

Chaucer, 15, 16, 18, 38, 106 note, $129,130,155,955$.

Chertsey, 216.

Cheselden, Mr. 102, 241, 243, 257.

Cheyne, Dr. 28, 193.

$\longrightarrow, M r .250$.

Chiabrera, $75,91$.

Chillingworth, 248.

Chinese, the, 51, 52, 73.

('holmondeley, Mr. 276.

Christoferi, Signor, 66 .

Chute, Francis, $947,248$.

Cibber, Colley, 257, 264.

-, Theophilus, 287.

('icero, 69, 133, 150, 206, 207. $210,254,268,287$.

Clare Ilall Cambridge, 248.

Clarenton, Lord, 206,233 note.

Clarke, Dr. '26, 15:), 220, 219, $277,289$.

- Mi. 62 .

Claudian, 207, 210.

Clauclius, Caesar, 144.

Cleland, $M r .130$.

Clement XI, 38, 98.

- XII, 60 .

Cleveland, Duchess of, 13.

- Joln, 109.

Cleves, Princess of 169.

('lifford, Matthew, 51.

Cocchi, Dr. 75, 81, 81 note, 85, 99,145 .

Cock, Mr. 136 note.

Coleman, Mr. 88.

('ollet, Di. 251.

Collier, Jeremy, 229.

Colonia, Père de, 60.

Colosseum, 63.

Colossus, the, 7 .

Colvil, Abbé, 14:, 189.

Concord, Temple of, 70 .

Condé, Prince de, 99.

Congreve, William, 8, 10, 3., $36,101,120,175,177$ note, 235 note, 257,267 note, 286.

Coningsby, Lord, 124. 
Constantine, Arch of, 71, 96.

- Baths of, 71 .

Constantinople, 62, $173,175$.

Conti, Princess de, 39.

Con ybeare, Dr. 253.

Coote, Mr. 265.

Copernicus, 80.

Corbet, Bishop, 17.

Corneille, $7,8,27,49,141$.

Corradini, Carulier, 183.

Corregio, 81, 171.

—

- his Muleteer, 138.

Corso, the, 69 .

Cortona, 95.

Coste, Pierre, 81.

Courayer, Father, 6, 30, 140.

Cowley, Abraham, 10, 17, 130, 209, 216, 258.

Cowper, Lord Chancellor, 999 note, 248, 253, 280.

Coypel, 139, 173.

Craggs, Secretary, 137 note, 161 . 232.

Cramer, M. 61.

('rashaw, Richard, 17.

Creech, Thomas, 130, 951 note.

Crellius, 282.

Crescimbeni, 99.

Crete, 96 .

Cromwell, Henry, 126.

-, Oliver, 37, 58, 59, 217, 296.

Crown, John, 34.

Crudeli, 77, 84, 85, 87, 90, 93, 94,96 .

Cudworth, 11.

Cumberland, Richard, 261.

Cyrus, 39.

D'Aceilly, Marot, 17.

Dallaway, Mr. 175 note, 177 note.

Damiano, Saint, 64.

Daniel, samuel, 17.

Dante, $74,75,83$ note, 259.

Davenant, Sir William, 7, 17, 18, 109, 128, 130, 148, 203.

- Mrs. 203.

Dean, $M r .196$.
De Cerisis, Habert, 17.

De Foe, 196.

Deities of the Greeks, 27 note.

Della Casa, Giovanni, 259.

Demosthenes, 254.

Denham, Sir John, 155, 213.

Dennis, Mr. 33, 15\%, 208.

Derby, William, Earl of, 175 note.

Derham, 251.

Descartes, René, 11.

Devonshire, Duke of, 256.

Diaper, Mr. 268 note.

Dictionary, authorities for an English, 235.

Dinocrates, 157, 158 note.

D'Israeli, Mr. 109 note, 201 note.

Ditton, 152.

Dobson, Mr. 135, 375.

Dodington, Bubb, 249.

Dodsley, Robert, 106 note, 267 note.

Dominichino, 66, 69, 72 .

Donne, John, 17, 102, 109, 128, 130.

Dorset, Lady, 3.

- Earl of, 16, 38, 102, 119, $212,256,257$.

Drayton, Michael, 16.

Drift, a servant of Pryor's, 36.

Drogheda, Lady, 33.

Drummond, Mr. 262.

Uryden, John, 4, 6, 7, 11, 19, $34,35,36,45$ note, $46,47,48$, 102 note, 105, 119, 128, 129, 153, 134 note, 197, 198, 199, 212, 216, 235 note, 239, 252, 254,283 .

Durfey, Thomas, 8.

Edinburgh, 249.

Education, its effect on the mind, 9.

Edward the Black Prince, 283.

Egyptian Statues in Rome, 64.

- three sorts of, 67 .

Elizabeth, Queen, 132.

Emanuel I, 166.

- II, 166 . 
Englefieh, Mr. 270.

Eipictetus, 17.5 note.

Epicurus, 107.

Erasmus, 11.

Erythraus, 15.).

Esprit, James, 9,

Fissex, Lord, $201,95$.

Estcourt, Richard, 137 note.

litherege, Sir George, 3.5, 47 .

Etruria, 95.

Eugene, P'rince, 251.

Fairfax, Fdward, 10.

Fanshaw, 251.

Farqular, George, 51, 251.

Fatio, 43.

Fauquet, M. 7.1.

Faustina, 69,70 .

Fenelon, Archbishop of Cambray, $20,21,29,25,27,29,38,40$, $43,1+1$.

Fenton, Elijah, 15, 248.

Fermor, Miss Belle, 147.

Ferrara, Duke of, 81.

Fiamingo, Susanna, 71 .

Fícoroni, Signor, 63, 71, 74, 85, $181,183$.

Fielding, I.ady Mary, 175 note.

Filicaja, Vincenzio, 91.

Firenzuola, A gnolo, 167.

Fletcher, John, 35, 235 note.

Fleury, Cardinal, 6, 29.

$\longrightarrow,-1 b b e,+13$.

- Claude, 261.

Florence, $75,79,85,88,89,143$ note, 167 .

Folengo, Tćofilo, 76 .

Fontaine, La, 17, 91.

Fontaines, Abbe des, 39.

Fontenelle, Bernard de, 99, 142 . Fortescue, Master of the Rolls, 109, 202 .

Fracastorius, 49,76 .

Franklin, 118 note.

Freij, Giacomo, 181.

Frowd, Pbilip, 215.

Galen, 83,84 .

Galileo, $75,70,80$.

— , the Architect, 96.
Garcilasso della Vega, 82, 83 note.

Gardens, liow they shoukd be laid out, 9, 158, 196, 287 .

(rardiner, 278 .

Garth, Di. 1, 2 note, 35, 8.), 86, $101,117,148,175,257$.

Gaty, 8, 10, 15, 18, 106, 110, 113, 120,136 note, $15 \%, 153,161$. 176,177 note, 221, 257 note, 26.1 .

Gaza, Theodore, 84.

Geddes, Michael, 283.

Geekie, 137 note.

Geneva, its Government, 61.

Genoa, Count of', 39.

George I, 14 note, 45 note, 195 note, 2331 .

- 11, 56 note.

Gerard, Lady, 272.

Germanicus, 60.

Giamone, 169.

Gibbon, Edward, 285 note.

(iibbs, Mr. 259.

Gildon, Charles, 112.

Godolphin, Lord, 58, 137 note: $206,237$.

Goff, Thomas, 16.

Golding, 16.

Gongora, 83 note.

Gower, 16.

Gracian, 150.

Grævius, 64, 154.

Grafton, Duke of, 190 note, 256 note.

Granville, Lord, 286.

Gravina, Abbaté, 86.

Gray, 237 note.

Greek Romances, 115.

Gregorio of Spoleto, 76 note.

Gregory Xil1, 68.

Gruter, 184.

Guarini, 19, 141.

Guicciardini, 259.

Guido, Dominico, 68.

一, Reni, 69, 180.

Habert de Cerisis, 17.

Hales, Dr. 292.

Halley, Dr. 42. 
Hallifax, Lord, 2, 101, 119, 137 note, 231,232 note, 256 note, 257 .

Hamilton, Count, 276.

Jandel, 237 note.

llannes, 254 .

Hannibal, 143, 144.

Hare, Bishop, 253.

Harding, Mr. 191.

Harrington, James, 57.

Harrison, William, 266, 268 note.

$\longrightarrow$, Dr. 266.

Harte, Walter, 222, 258.

Jlarillan, 155.

Henley, Antbony, 8, 267 note.

Henrietta Maria, Queen, 3 note. Henriquez Lewis, Pire, 233.

Henry 1V, of France, 67.

the Liberal, 283.

Herbert, George, 17.

- Lord, 287.

Herculaneum, 185.

Hercules, Statues of, 65, 68 .

- Medals of his latours, 173 .

Herodotus, 104.

Hervey, Lord, 177.

Jiesiod, 163.

Jinchinbroke, Lord, 215.

Iloadely, 118 note.

Hobbes, Thomas, 150, 158, 235 note.

Holdsworth, Edward, 97, 138 note, 142, 144, 145 note, 154 , 156.

Holland, 189; its Ecclesiastical Polity, 61 .

Homer, $7,18,29,39,74,75$, $104,163,196,19 \tau, 20 \tau, 209$, 210, 211, 215, 231, 239.

Hooke, Nathaniel, 25, 28, 40, $193,220,235,242,244,256$, 260, 272, 273, 279 note.

- $M r .288$.

Hooker, Richard, 235 note.

Horace, 1, 4 note, 39, 50, 75, 32, 96 note, 159, 161, 164, 190 , $197,213,295,251,265$.

Torren, Lollinna, 64.

Howeil, 105.
Hudibras, 157.

Hudson, Mr. 253.

Huet, 50.

Ilughes, John, 229 note.

Hutcheson, Francis, 134,

Hyde, Lord, 221.

Itex, the, 96 .

Improvisatori, 87, 88.

Isara, the River, 143.

ltalian Poets, 74, 78, 81, 82, 87. Writers, 259.

JACKSON, John, 27\%.

James I, 117.

— 1], 34, 117, 130, 250, 277

note; his Nemoirs in the Scotch College at Paris, 260.

Janus, Temple of, $1+1$.

Jervas, Charles, 17，20，179 note.

Jews, offer to purchase the Town of Brentford, 58.

- , their treaty with Cromwell, 58.

Job, Book of, 252 .

John, Friar, 156.

Johnson, Julian, $4 \tau$.

_- Dr. Samuel, 46, 229 note, 232 note, 273.

Jonas, Statue of, 70 .

Jones, Dean, 123.

_-, Mr. of Welwyn, 266.

Jonson, Ben, 4, 7, 17, 35, 151 note, 235 note.

Josephius, 222.

Juvenal, 82, 254.

Katt, Christopher, 256.

Ken, Bishop, 250.

Kendal, Duchess of, 258.

Kepler, John, 80.

King, Arehbishop, 152 note.

$\longrightarrow$ Dr. 105 note, 251, 288.

Kingston, Evelyn, Duke of, 256 note, 175 note.

Kircher, Father, 33, 259.

Jit-Kat Club, account of, 3i, 256.

Knapton, George, 60, 260. 
Kneller, Sir Godfrey, 12.1, 12:, $126,135,136,171,137,255$, $237,281$.

Kyd, Thonas, 16 .

\section{LA CERDi, 15.)}

Lacus Fucimus, 11 t.

Lansdowne, Lord, 17, 1 17, 153.

Lang, Mr. 258.

Litocoon, Statue of, $63,1 i 1$.

Laurel, the, 93.

Laurentian Library, 81.

Laws, good, difficult to be made effective, 10 .

Lazaritlo de Tormes, 49.

Lee, Nathaniel, 17.

Le Grand, 11. 117.

Legris, M. 60 .

Leicester, 121.

Leigh, Dr. 261 .

Leo $X, 85$.

Leon, Luis de, 83 note.

Le sage, M. 142, 188.

Lesley, Charles, 29.

L'Estrange, 22:, 2:35 note.

Lewis, Mr. 13\%, 195.

Lillo, George, 162.

Lintott, Bernard, 112, 147, 221 note, 269 .

Lippi, $i 7$.

Lisbon, 117,124 .

Livy, 62, 143.

Locke, 11, 22, 37, 81, 150, 151, $175,212,220,235$ note.

Lockier, $D_{i}$. $4+$ note, 51 note.

Longinus, 50.

Lope de Vega, 50, 83.

Lorenzo de Iredici, 71, 130.

Lorenzetto, 70.

Louis $\mathrm{X} 1 \mathrm{~V}, 21,22,258$.

$-\mathrm{XV}, 29$.

Lowth, Dr. 280.

Lucan, 195 note.

Lucius Verus, 69, 2.55.

Lucretius, 107, 130, 215, 251.

Lyons, 116 note, 143.

Lyttleton, Mr. 242, 265.

Macchiavellt, 49, 75, $79,80$. Madrid, 63.
Maffei, Marqueis, 63, 65, 85, 158.

Magliabecthi, 16is note.

Natiomet, 3:.

Maintenen, Madum de, 91, 253.

Malebrancle, 233 .

Mallierbe, 8, 93.

Mallet, Barid, 201, 249.

Natone, lidmund, to note, 133, 197,282 note, 198.

Manchester, Earl of, 256 note.

Manfredi, Lustachio, 78, 91.

Mamilius, 1:30.

Mannick, $M / r .19,256$.

Manrique, 83 note.

Mansfield, Lord, 230.

Mantegna, Andrea, 170.

Mantua, Duke of, 165, 187 .

Nanwaring, Mir.119, 257 .

Mar, Lady, 177 note.

Marratti, Carlo, 68, 69 note, 153, 171.

Marcellus, 66 .

Marchetti, 85 .

Marchmont, Lord, 227 note.

Marforio, 65, 85.

Mariana, 50 .

Marino, 17.

Marivaux, Pierre, 142.

Markham, Gervase, 8.

Marlborough, Duke of, 23, 25, 11 mote, 108, 122, 123, 12 237, 238, 256 note.

— Duchess of, 223, 237, 277, 278.

Marot, 17.

Marshal, Lord, 5.5

Marston, John, 16.

Martial, 68, 144.

Mlary, Princess, 250.

-, Queen, 119.

Mason, William, 237 note.

Mitssingberd, Mr. 280 .

Massinger, 16, 131.

Maty, Dr. 201.

Maundrel, 276 .

Maurice, Cardinal, 165, 166.

Mauro, 77 .

Maximilian, Emperor, 28.5 note.

Mendoza, Ilurtado de, 49 note, 83 note. 
Mennis, Sir John, 17.

Menzini, 82, 91.

Metastasio, 91.

Mezentius, 95.

Middleton, $D r$. Conyers, 235.

Mignard, Peter, 24 note.

Mildmay, Sir Henry, 281.

Milton, John, 16, 27, 129, 131, $132,149,151,197,209,235$ note, 237 note, $242,261$.

Mirandula, Count of, 124.

Moliun, Lord, 256.

Molesworth, Lord, 44 note, $\mathbf{5 1}$, 58,59 .

Iolière, 49.

Molza, 17.

Montague, Duke of, 249.

_- Lady M. IV. 169 note, 173,175 note, 176 note, 177 note, 179 note, $221,282$.

Montaigne, 37, 150.

Montaiuti, Count Torquata, 90 91.

Nontalta Gardens at Rome, 170, 181.

Monte, Cavallo, 71 .

- Citorio, 182. di Pietà, 68.

Montesquieu, 123, 173, 250.

Montmenil, M. 189.

Monville, Abbe de, 24 note.

More, Sir Thomas, 37, 152.

Morei, Abbé, 140 note.

Morgan, Mr. 153.

Morose, a real character in the time of Ben Jonson, 7.

Mosaic Work, 65, 182.

Mount Athos, 157.

—C Cenis, 143.

- Lebanon, 198.

_- St. Bernard, 143.

Muratori, 91.

NIusæus, 163.

Music, Freuch and Italian, 63.

Mysteries, account of, 234 .

Najarra, Battle of, 283.

Naples, 82, 116, 169, 185.

Neptune, 181.

Nero, Emperor, 172.
Newark, Viscount, 175 note.

Newcastle, Duke of, 131 note, 198, 227, 256 note.

Newton, Bishop, 45 note.

- Sir Isaac, 11, 29, 40, 43, $54,81,132,247,276$.

- John, 276.

Nicholas V, 11.

Nichols, Jolnn, 36 note, 267 note.

Niobe and her Children, group of, 183.

Novels and Eastern Tales corrupt the taste, 275 .

Occleve, 255.

Ogilby, 149, 209.

Oglethorpe, General, 241.

Oldfield, Mrs. 114, 290,

Oldham, John, 14, 102.

Oldisworth, William, 251, 267 note.

Onslow, Speaker, 260.

Orange, Prince of, 250, 256.

Orleans, 57 .

Ormond, Duke of, 55 .

Orpheus, Statues of, 170.

Osorio, Count, 108.

Otho, Vænius, 164.

Otway, 33, 162.

Ovid, 1, 16, 19, 175, 207, 209, $210,214$.

Oxford, Physic Garden at, 109.

- , Lord, collection of original Letters, 4, 80, 105 note, 110, 115 note, 132 note, 134, 135, 152, 153, 154, 210, 226 note, 231, $237,255,258$.

$\longrightarrow$, Lady, 169 note.

Panua, 185.

Paintings of the Ancients, 259.

Palais Royal at Paris, collection of Pictures there, 138.

Palazzo Altieri, 69.

- Barberini, 155.

- Colonna, 69.

- Farnese, 63.

Lancillotti, 68.

Palladio, 80. 
Pan, Statue of, 17\%.

l'arker, Lord Chancellor, 195 note, gog note.

Parnell, Thomas, 104, 110, 152, 219, 269 note.

P'asyuin, 84, 8;.

Paterculus, 10 t.

Paul, Father, $1+11$.

Pearce, B.of Rochester, 45 noie, 50.

Pedro the C'ruel, 283.

Peele, 118.

Peenbroke, Lard, 247.

Penn, 116, 117.

Penusylvanian Laws, 117, $20^{\circ}$.

Pennus, the (God, 106.

Penton, $1 \mathrm{Ir}, 260$.

Percival, Mr. 270.

Perez, Gonzalo, 83.

Perfetti, 78, 89.

Persius, 159, 254.

Pertinax, 173.

Peterborough, Lord, 24, 3i3, 102, 114,115 note, 116, 124, 190 note, 215, 293, 958.

Petrarch, 17, 7 $4,75,77,82,83$, $89,169,239$.

- and Laura, 3\%.

Petre, Lord, 1 t8.

Pes cennius, 17\%.

Phaer, his Virgil, 16.

Phidias, 71.

Philip II, 8\%.

Philippeaux, Abbé, $1 \neq 2$.

Philips, Ambrose, $71,110,112$, $131,148,257,258,261$.

Pianoro, 167.

Pietra Mala, 167 .

Pindar, 134, 915, 231, 265.

Pitt, Rev. C. 197, 28?.

Place de st. Marc, 136 note.

Plato, 150, 206, 215.

Plautilla, Gem of, 172.

Pliny, 133, 168.

Plot, Dr. 253.

Pluche, $A b b 5,936$.

Plutarch, 215.

Plymouth, Lord, 162 note.

Polignac, Cardinul, 27, 159.

Politian, 17, 87, 207.

Polybius, 143, 14.
Polycletes, ivory statue of, 7 .

Pounfret, Ladi, 179 note.

Pompey, statue of, 6 t.

Pontanus, 50.

Pope, his opinion of llorace's Art of Poetry, 1.

_- his life several times in danger when young, 4,5 .

- , his great application, 5 .

, his gratefin recollection of kinduess, 6 .

—, his farouriteauthors among the English Poets, 6 .

when young, 6 .

- - , his desire to travel, $\tau$.

_- adrised by $\Lambda$ ddison not to list under party, 7 .

-, , his opinion of the French Poets, 8.

- , his account of the Memoirs of Scriblerus, 8.

be proved disguised virtues, 9 .

- his first intentions as to his Essay on Man, 12, 36, 235.

$\longrightarrow$, his opinion of the English Poets, 10, 11, 12, 13, 127, 128, 129,130 .

17.

- - , his idea liow a poem should be corrected, 18 .

—_, commenced writing poetry early, 19.

facility, 19 .

35,36 .

$\longrightarrow$, his idea of writing American pastorals, 106 .

- his poems quickly written, 107.

_-, his idea on self-love, 109.

, his dislike to speak in public, 118.

- his opinion on epistolary writing, $1: 33$.

, account of his early reading, 146, 211. 
Pope, his view in writing the Rape of the Lock, 147.

- - , wrote a tragedy when young, 149.

, his feeling towards middling poets, 150 .

- his inclination for antiquarian studies, 154 .

$\longrightarrow$, his opinion of Hudibras, 157.

- his opinion on the placing of prepositions, 160 .

- his ideas of politeness, 161 .

- $\quad$, his dread on commencing his Jomer, 164.

- , quarrel with Lady W. Montague, 177 note.

life, 196.

—_, a Whig, a Reformist, and almost a Republican, 200 and note.

- method pursued in the translation of Homer, 205.

$\longrightarrow$, favoured the idea of the transmigration of souls, 205 .

- , his fondness for reading, 208.

- - his design of an epic poem, 211, 218. * $\frac{p}{\text { from Dryden, 212. }}$, wholly

- - , his excellent memory, 215. - , desires to be buried with his fatler and mother, 219.

- his opinion of theological writers having corrupted the truth, 220 .

- opinion that there are no rules for writing the English language, 220.

$\longrightarrow$, his feeling and humanity, 221.

- $\quad \frac{22}{4}$, the sum paid him for his Homer, 224.

- his high opinion of Spenser, 224 .

- the occasion of his translating some of the Satires and Epistles of Horace, 225.
Pope, his idea of the consistency of fore-knowledge and freewill, 228.

_ how little he feared death, 228.

$\ldots$, his intention of translating from the most celebrated Greek Poets, 231.

-, his independence, 231234 ; and liberality, 234.

- , his Pastorals the most laboured of his works, 236 .

237.

— Bolingbroke, 259, 240.

- , his reliance on the immortality of the soul, $24 \cdot 1$.

$\longrightarrow$, his death, 244 .

Porta del Popolo at Rome, 181.

Portici, 185.

Portsmouth, Duchess of, 248, 280.

Pouilly, M. de, 12 note.

Poverino, 167.

Praxiteles, 71.

Pretender, the, 55, 99, 115 note, 206, 228, 237, 248.

Printing, origin of, 93 .

Prior, N. 2, 17, 36, 102, 132, 135, 235 note, 258.

$\longrightarrow$, his Chloé, 37.

Prussia, King of, 168.

Pulteney, William, Earl of Buth, 216, 240 note, 257.

Quakers, 263, 264.

Queensbury, Duke of, 162, 195 note.

Querno, Camillo, 85.

Quevedo, 83 note.

Quintilian, 147.

Rabelais, 106, 156, 176.

Racine, 7, 8, 27, 49, 141,

- the younger, 289.

Racket, Mrs. 4, 20 note, 156, 202.

Radcliffe, Dr. 6.

Radnor, Lord, 18. 
Raleigh, Sir Walter, 235.

Rambouillet, Mademe de, 13.

Ramsay, Cheralier, 21, 20, 25, $26^{\circ}, 27,28,38,39,42,7$ t note, $99,100,111,142,206,25 \%$, $261,289$.

Randolpl, Thonas, 17, 109 .

Raphael, 70, 72, 81, 180, 259.

Rapin, 146, 278 .

Rawlinson, Mr. 193.

Redi, 91, 169 .

Regnit'r, 50 .

Regulus, $1+1$.

Religion, Catholic, 98.

Retel, Battle of, 99 .

Reynel, Mr. 954.

Reynolds, 261.

Rhone, the, 113.

Riccio, Abate del, 79, 8 0.

Richa, Coutut, 166, 167.

Richardson, Mr. 124 note, 136 note, 176 note, 226 note, 260 , 261 .

Richmond, Duke of, 13, 33, 31, 256 note.

Rioja, Francisco de, 83 note.

Rivers, Countess of, 270 .

Robins, Mr. 280.

Robinson Crusoe, 196, 253.

Rouchefoucault, 150.

Rochester, Lord, 1, 1t, 50, 102, 103 note, 151, 212, 213.

- Bishop of, 277 note.

Rollin, 194.

Roman Sculpture, 69 .

Rome, $58,63,64,67,74,75,80$, $82,87,93,97,154,165,184$.

-, Ichnography of, 63 .

Romulus and Remus, Temple of, $63,66,69$.

Rosalba, Signora, 186.

Rose, Stewart, 77 note.

Rotunda at Rome, 67, 70 .

Rouille, 260.

Rousseau, 98, $1+1$.

Rowe, 2, 131, 131, 195, 196 note, $215,290$.

Rubens, 260.

Ruff head, Owen, 195 note, 218 note, 273, 279 note, 281 note, $289,290$.
Russell, Lord, g21.

Russia, Empress of, 88.

Rycaut, Sir Pitul, H note, 58.

Rymer, Thomas, 130.

Sicchi, Audrea, 72.

Sacheverel, Dr. llenry, 37, $11 \mathrm{j}$ note.

Sadoletus, 17, 50 .

St. Andre, 115 .

st. Angelo, ('astle of, 66 .

St. Bermard the Great, 166.

st. ('hristopher, lsland of, 230 .

st. Cosmo, 64 .

St. Evromond, M. 134.

St. George, Cherulier, 29.

st. Jimes's P'urk, 94 .

st. John, 147, 267 note.

Sallier, 12 note.

Salrini, 51, 77, 92.

Sandys, M. 132 note.

- George, 209.

Sannazaro, 49, 50, 76 .

Santa Maria Maggiore, Church of, 67 .

- del Popolo, Church of, 70.

Sarazin, 7 .

Sardinia, King of, 59, 108, 227.

Savage, Richard, 270 .

Saville, $M r$. 255.

Savoy, King of, 165 note.

Sbarra, Signor, 80.

Scaliger, J. C. 150.

Scarpellino, 89.

Schlegel, 83 note.

Schreibler, 8.

Scipio, 239.

Scotch travellers, men of sense, 55.

Scriblerus Club, 191 note.

- Memoirs of, 8, 133, 219.

Sedley, Sir C'harles, 103.

Selden, John, 261.

Self-love, 109.

Seneca, 16, 128, 133, 150 .

Senses, the, 11.

Septimius Severus, 84 ; Arch of, 173.

Settle, Elkannah, 47, 51 . 
Shadwell, Thomas, 33, 47.

Shakespeare, $4,18,27,35,49$, $110,129,131,133,151$ note, $203,204,235$ note.

Shaw, Dr. 95, 265.

Shrewsbury, Lord, 124.

- , Lady, 124.

Sidney, Sir Philip, 49.

Sienna, 89.

Silius Italicus, 95.

Simplon, the, 158 note.

Sinclair, Mr. 270 .

Sixtus $V, 71$.

Skelton, Joln, 130.

Smalridge, Dr. 190 note.

Smith, Rag., 20 note.

- Actor, 46.

Soames, Sir IV. 278.

Socinus, 282.

Socrates, $2+1$.

Somers, Lord, 137 note, 256 note.

Somerset, Duke of, 256 note.

Sophia, the Princess, 55.

Sophocles, 27.

Southampton, Toun of, 116 note. , Lord, 216.

Southcote, Abbc, 5, 6, 289.

$-, M r .275$.

Soyer, M. 62 .

Spada, Cardinal, 64.

spain, some account of the manners in, $178 \mathrm{et}$ s $\mathrm{eq}$. 62 .

Spanish Poets, 82.

\section{- Critics, 11.} Language, 83 note.

Spenser, 6, 16, 18, 38, 82, 129, $209,224,225,235$ note.

- William, 261.

Sperone, 75.

Spinosa, 26, 32.

Sprat, Dean, 10, 51, 130, 216, 235 note.

Stanhope, Lord, 257.

Stanley, 17, 150 .

Statius, 209, 210, 211.

Statues in Rome, 63, 61, 65, 70, $71,9 \mathcal{2}$.

Steele, 35, 36, 111, 119, 141,
$148,149,153,175,247,254$, 257,267 note.

Stepney, George, 257.

Stosch, Baron, 84, 92, 172.

Strafford, Lord, 368.

strahan, Mr. 229 note.

Stratford-on-Avon, 203.

Style in writing, 126,127, 131 133.

Suckling, Sir John, 2, 3, 17, 51.

Suetonius, 141.

Sunderland, Lord, 337, 256 note.

Swift, 8, 15, 18, 50, 51 56 106, $119,120,121,152$ note, 156 , 176,190 note, 194, 200 note, 220,229 note, 233 note, 235 note, 254, 255, 265, 268 note, $270,286,290$.

Switt's Stella, 268 note.

Sylvester, Joshua, 17.

Tabula Isiaca, the, 166.

Tanner, Bishop, 252 iote.

Tarchon, 95, 96 .

Tarentum, 82.

Tarpeian Rock, its height, 69 .

Tarquinius Priscus, 119, 155.

Tasso, 49, 75, 77, 81, 82, 83 note, $85,87,91,211$.

Tassoni, 46 .

Tate, Nahum, 47.

Temple, Sir William, 151, 220, 235 note.

Terence, 200.

Theohald, Lewis, 14, 114.

Theocritus, 163.

Thomas, Dr. John, 45 note.

- Mrs. 198 note.

Thomson, James, 105 note, 249, 258.

Tiber, height of the water, 181 .

Tibullus, 1, 82.

Tichburne, Sir Harry, 196.

Tickell, Thomas, 2 note, 35, 110 , 111, 112 note, 264.

Tilleman, Painter, 18.

Tillotson, Archbishop, 39, 208, 220, 235 note.

Titian, 169 . 
Tenson, Jacob, 3., 36, 18, 134 note, 1360 note, $147,151,159$, 252 note, 2.56, 201, 26\%.

Tormes, Lazarillo de, 19 and note.

Torre, Francisco de la, 83 note.

Toulon, 199.

Toulouse, Count of, 139 .

Towuley, Mr. Charles, 86, 167 note.

Trajan, Arch of, 71,97 .

--, Column of, 71,18 t.

-

Trappi, $I), 113,1 \% 9$.

Trumbull, Sir William, 1 t7.

Tullia, 11 ?

Turenne, Marshal, 32, 99, 141.

Turin, $165,170,223$.

Turks, their customs, $173,174$.

Twickenham, 171, 177 note, 219, 248.

Twy ford, 7, 19, 146, 196.

Tycho Brahe, 5?.

Urwis, William, 199.

Vexius, Otho, 164.

Vanbrugh, Sir John, 35, 235 note, $257,265$.

Vander Gutcl, 137 note.

Vanity, 154.

Vanneschi, Signor, 88, 89.

Vatican, the, 65 .

Venice, 87,136 note, 187 .

Venus, 27 note: Statues of, 169.

Venuti, Cavalier, 95.

Verona, 63.

- , ancient theatre at, 159.

Versailles, 187.

Vespasian, Amphitheatre of, 97.

Vicar of Bray, 37.

Victor, King, 166.

Vida, 49,76 .

Villa, Borghese, 64 .

- Madama, 14.

- Medici, 183.

Villars, Marshal, 156.

Villegas, 83 note.

Vinci, Lionardo da, 171.

Violante, Princess, 90.
Virgil, 7, 8, 18, 19, 75, 8.5, 89, 93 note, 94, 96, 97, 98, 105, 133,134 note, $142,155,162$, $163,164,198,207,210,215$, 236 .

Vitruvius, 96.

Viturbo, 74.

Vives, Ludovicus, 155.

Voiture, $7,17,1: 33$.

Voltaire, 141, 201 note, $251,285$.

Volterra, 72.

Vossius, 15.5.

Vulcan, his forge, 181.

W Aке, Dr. 252 note.

Waldegrave, Lord, 250.

Wales, Prince of, 281.

Waller, $6,17,19,153,214,23$, note.

Walpole, Sir Robert, 6, 227, $257,282$.

- Horace, 176 note.

Walsh, William, 19, 147, 210, 212.

Walton, Dr. 250.

Warburton, Bishop, 195 note, $231,236,256,272,277,281$, 287, 290.

Ward, Edward, 199 note.

Warton, Joseph, 102 note, 138 note, 143, 176, 191 note, 196 note, 244 note, $273,289$.

- Thomas, 251 note.

Warwick, Lord, 112, 113.

- Countess of, 36, 148.

Waterland, Dr. 277.

Watts, Mr. 36 note.

Wearg, Mr. 118 note.

Webster, John, 16.

Welwood, Dr. 195 note.

West, Gilbert, 134, 265.

Wharton, Duke of, 179 note, 193, 266.

$\ldots$, Lord, 122 note, 256 note.

Whiston, William, 50,152 .

Whitehall, 58, 216.

Whitehead, 130.

Whitton, 395 note.

William 1I1, 119, 248, 250, 256, 271. 
Wills' Coffee House, 199, 216.

Vilson, 251.

Winchester, Bishop of, 250.

—, Dean of, 250.

College, 287.

Windham, Sir William, 210 note.

Woodward, $\mathrm{Dr} .8$.

\section{— Printer, 118 note.}

Words, number of, in different languages, 78.

Wortley, Mr. 175.

Wotton, Sir Henry, 8.

Wren, Sir Christopher, 194.
Wycherley, 2, 10, 13, 14, 19, $33,34,35,112,113,114,121$, $147,149,150,151,215,221$, $255,256,289$.

Xenophon, 145.

Yon к, Duke of, 194, 250.

Young, Dr. 2 note, 111, 131, 193, 249, 253, 266, 267 note, $268,269,270,285,286,287$, 288.

Zulestien, 250.

\section{ERRATA.}

Page 30, 31, lines 27; 2, 12, for Bourdelot read Bourdaloue.

" 76 , line 8 note, for Gregoris read Gregorio.

„, 95, ,23, for lecto read lectos.

„172, "16, for Bianchini read Bianchi.

",203, ," 6, for Bailey's read Bayle's.

"233, ", 5 note, for design read deign. 



\section{ZETURN CIRCULATION DEPARTMENT 202 Main Library

\section{ALL BOOKS MAY BE RECALLED AFTER 7 DAYS}

Renewals and Recharges may be made 4 days prior to the due date. Books may be Renewed by calling $642-3405$.

\section{DUE AS STAMPED BELOW}

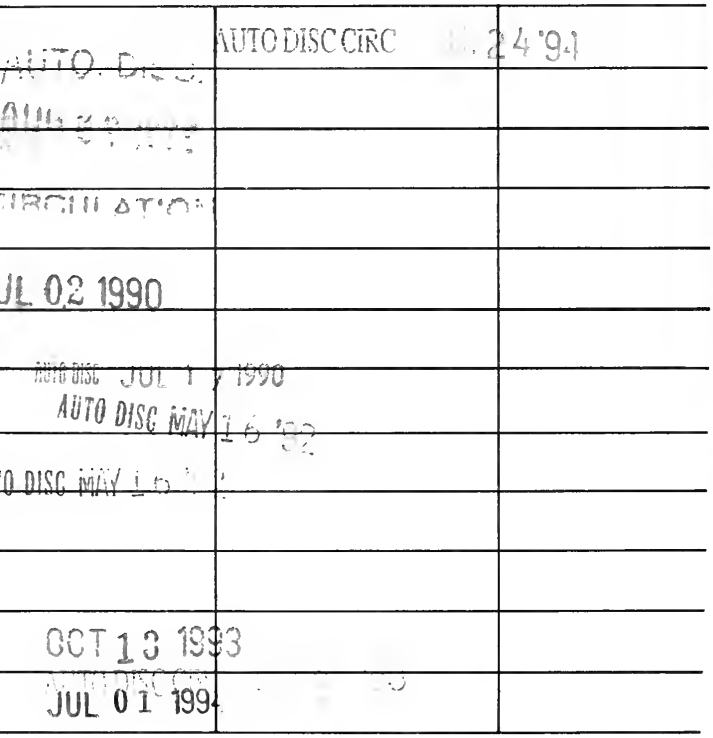




\section{U.C. BERKELEY LIBRARIES}

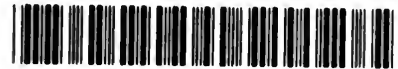

C005357923

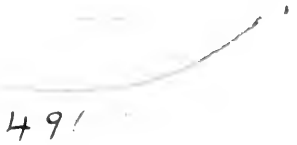

UNIVERSITY OF CALIFORNIA LIBRARY

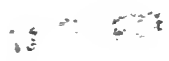




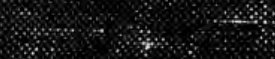

$8 \% 8$

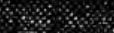

$\frac{3}{20}+2$

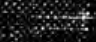
$\%$

2.

s.

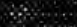

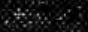

\%

$\cos 20$. 